SANDRA REGINA CARVALHO MARTINS

Uniões Homoafetivas: Da Invisibilidade à Entidade Familiar

Dissertação de Mestrado

Orientador: Professor Titular Dr. Álvaro Villaça Azevedo

UNIVERSIDADE DE SÃO PAULO

FACULDADE DE DIREITO

São Paulo-SP

2015 
SANDRA REGINA CARVALHO MARTINS

Uniões Homoafetivas: Da Invisibilidade à Entidade Familiar

Dissertação de Mestrado apresentada à Banca Examinadora do Programa de Pós-Graduação em Direito, da Faculdade de Direito da Universidade de São Paulo, como exigência parcial para a obtenção do título de Mestre em Direito, na área de concentração Direito Civil, sob a orientação do Professor Titular Dr. Álvaro Villaça Azevedo.

UNIVERSIDADE DE SÃO PAULO

FACULDADE DE DIREITO

São Paulo - SP 
BANCA EXAMINADORA 


\section{Homossexualidade ${ }^{1}$}

O menino homossexual está em guerra.

Ainda não sabe que é homossexual.

Nem que está em guerra.

Também não sabe as causas dos dois fatos. No entanto, ele nasceu em guerra.

Maldição, a de ter sido parido em território inimigo.

O menino judeu sofre a estupidez do mundo e volta para a casa e em casa seus pais judeus lhe dizem "estúpido é o mundo, você não". E lhe contam por que esta noite não é como todas as noites e sobre aquela vez que tiveram que sair correndo, e o pão não cresceu. Dão-lhe uma lista de valores e tradições e lhe dizem: "O seu lugar é aqui". E o menino judeu saberá que não está sozinho.

O menino negro sofre a estupidez do mundo e volta para casa e em casa seus pais negros lhe dizem "estúpido é o mundo, você não". E lhe contam sobre o berço da humanidade, sobre um barco, uma guerra. Dão-lhe uma lista de valores e tradições e lhe dizem: "O seu lugar é aqui”. E saberá que não está sozinho.

O menino homossexual sofre a estupidez do mundo e nem pensa em falar com seus pais. Acha que eles vão ficar chateados. Ele não sabe o porquê, mas eles vão ficar chateados. E o pior para os pais é acreditar que seu filho não é como eles.

O menino homossexual enfrentará algumas estupidezes.

Será parte de uma minoria com a qual as maiorias estabelecem, geralmente, relações de crueldade. As maiorias heterossexuais se acharam, ao longo dos séculos, moralmente superiores e, portanto, com direito a decidir como têm que viver os demais.

A homossexualidade - na verdade, todas as sexualidades não reprodutivas - foi pecado para as religiões, foi doença para a ciência e foi crime para o direito e os Estados. O poder nunca nos quis.

O menino homossexual, só por ter nascido homossexual, só por ter sido parido em território inimigo, está em guerra com a religião, com a ciência e com o Estado. Como poderia um menino enfrentar uma luta tão desigual? Com que armas? Onde está o adulto que o escute?

(Texto de um discurso pronunciado por Osvaldo Bazán, escritor argentino, autor do livro "História da homossexualidade na Argentina", em uma audiência pública realizada durante o debate da lei de casamento igualitário na Câmara dos Deputados).

\footnotetext{
${ }^{1}$ BAZÁN, Oswaldo. Homossexualidade. Disponível em: http://casamentociviligualitario.com.br/opinioes/. Acesso em: 01 jan. 2014.
} 


\section{AGRADECIMENTOS}

Ao meu orientador, Professor Titular Dr. Álvaro Villaça Azevedo, por me aceitar como sua orientanda, em um tema tão polêmico e controverso, apoiando, orientando e respeitando sempre minhas pesquisas.

Ao Professor Doutor Dr. Jorge Shiguemitsu Fujita por todo incentivo e estímulo ao longo desta jornada.

Ao Professor Titular Dr. Rui Geraldo Camargo Viana, por suas relevantes observações proferidas no exame de qualificação.

Ao Professor Titular Dr. Carlos Alberto Dabus Maluf, por aceitar ser meu Supervisor no Estágio Supervisionado em Docência do PAE (Programa de Aperfeiçoamento de Ensino) e pelas valiosas ponderações feitas no exame de qualificação.

À Dra. Maria Lucia Beffa, Chefe Técnica de Serviço da Biblioteca e Documentação da Faculdade de Direito da USP, pela ajuda recebida durante minha pesquisa.

Ao meu marido, José Geraldo Martins, ao meu filho Alexandre Carvalho Martins e à minha filha Juliene Carvalho Martins pela compreensão durante esses anos. 


\section{RESUMO}

Esta Dissertação tem como objetivo o estudo das uniões homoafetivas desde a inexistência jurídica destas uniões, passando pelo reconhecimento como uma sociedade de fato e não como um instituto do direito de família, até chegarem aos dias de hoje, com o reconhecimento pelo Supremo Tribunal Federal, como sinônimos perfeitos de família. Analisa os pré-conceitos sobre a homossexualidade ao longo da história, e a formação do preconceito advindo de tais concepções. Mostra a evolução da família formada por pares homossexuais na legislação, na jurisprudência e na doutrina. Partindo do exame dos fundamentos da união estável e do casamento, analisa a evolução destes institutos fundados inicialmente na diversidade de sexos até a aceitação atual para os pares homossexuais. A homoparentalidade é estudada sob as formas da adoção, da reprodução artificial medicamente assistida e da gestação de substituição. O panorama estrangeiro é mostrado por meio da visão, sobre o assunto, de vários países. Ao final, são apresentadas as propostas de alterações legislativas existentes, finalizando com a nossa proposta legislativa.

Palavras-Chaves: Homossexualidade - Família Homoafetiva - União Homoafetiva - Casamento Homoafetivo - Casamento Inexistente Homoparentalidade. 


\section{RÉSUMÉ}

Cette dissertation a comme objectif l'étude des unions homo-affectives* depuis l'inexistence juridique de ces unions, en passant par la reconnaissance comme une société de fait et pas comme une institution du droit de la famille, en arrivant jusqu'à aujourd'hui, avec la reconnaissance par la Cour Suprême comme équivalent de la famille. Elle analyse les préjugés sur l'homosexualité à travers l'histoire et la formation du préjudice découlant de ces conceptions. Elle montre l'évolution de la famille formée par des couples homosexuels dans la législation, la jurisprudence et la doctrine. En se basant sur l'examen de l'union stable et du mariage, on analyse l'évolution de ces institutions d'abord fondées sur la diversité des sexes jusqu'à l'acceptation actuelle des couples homosexuels. L'homoparentalité est étudiée dans ses différentes formes que sont l'adoption, la reproduction artificielle médicalement assistée et la grossesse de remplacement. Le panorama étranger est représenté par la vision sur le sujet de plusieurs pays. Enfin, les propositions des changements législatifs existants sont présentés, en achevant par notre proposition législative.

Mots clés: homosexualité, famille homo-affective, union homo-affective, mariage homo-affectif, mariage inexistant, homoparentalité.

*du grec opo + du latin affectivus 


\section{SUMÁRIO}

INTRODUÇÃO. 12

PARTE 1

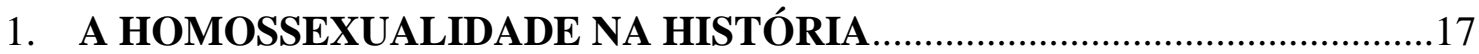

1.1 A homossexualidade e a civilização grega.....................................................17

1.2 A homossexualidade e a civilização romana..................................................21

1.3 A homossexualidade na Idade Média............................................................27

1.4 A homossexualidade na Idade Moderna e nos dias atuais................................29

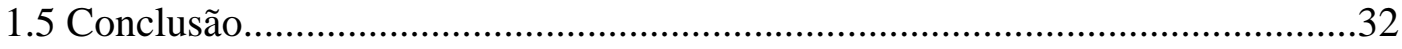

2. PRÉ-CONCEITOS SOBRE A HOMOSSEXUALIDADE..................................

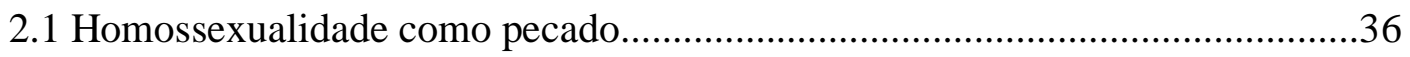

2.2 Homossexualidade como crime...................................................................44

2.3 Homossexualidade como doença...............................................................48

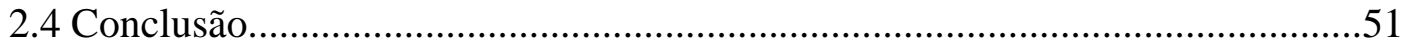

3. CASAMENTO HOMOSSEXUAL NA LEGISLAÇÃO ESTRANGEIRA........54

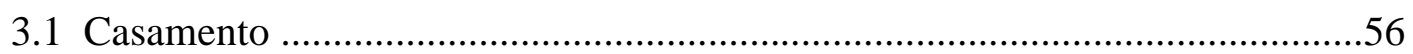

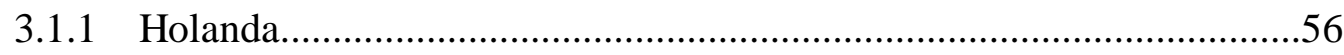

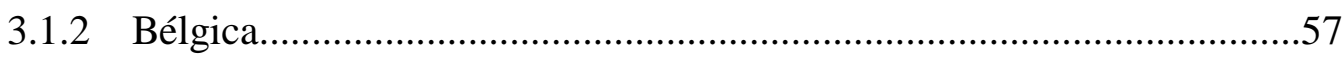

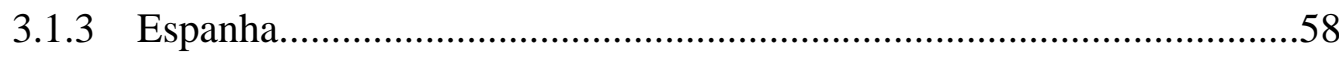

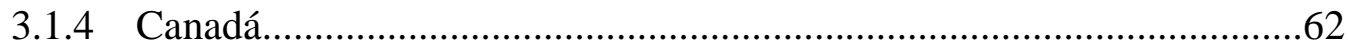

3.1.5 África do Sul.........................................................................64

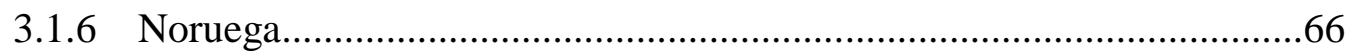

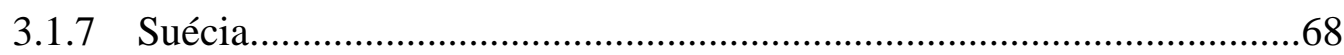

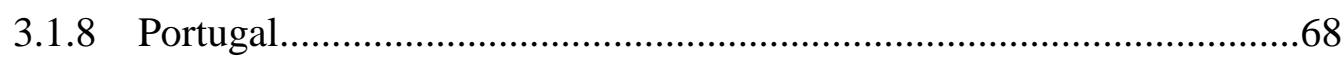

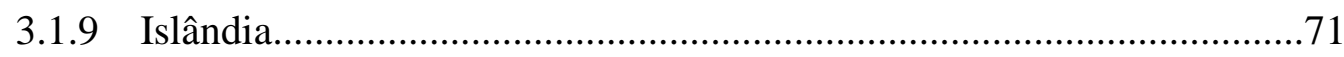

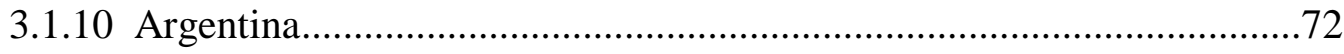

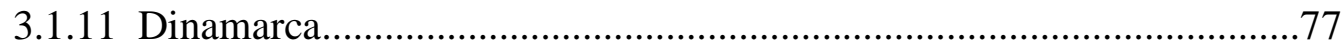

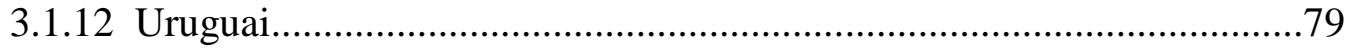




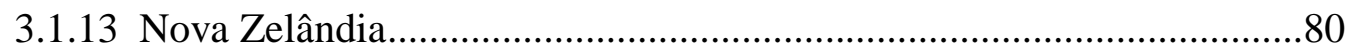

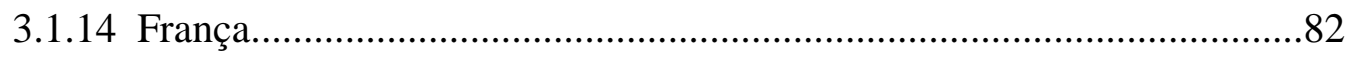

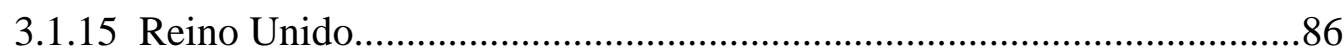

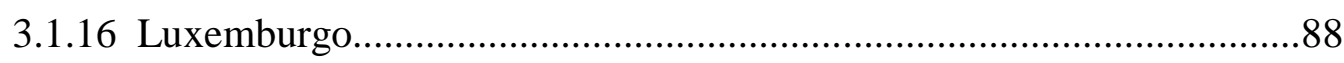

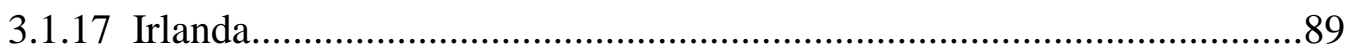

3.1.18 Estados Unidos...........................................................................90

3.1.18.1 Massachusetts e Connecticut................................................94

3.1.18.2 Iowa e Vermont...................................................................97

3.1.18.3 New Hampshire e Nova Iorque...............................................98

3.1.18.4 Washington, Maine e Maryland..............................................99

3.1.18.5 Rhode Island, Delaware e Minnesota......................................101

3.1.18.6 Califórnia, Nova Jersey e Havaí............................................103

3.1.18.7 Illinois, Novo México e Oregon..............................................105

3.1.18.8 Pensilvânia, Virgínia e Oklahoma.........................................108

3.1.18.9 Uthat, Wisconsin e Indiana.....................................................109

3.1.18.10 Idaho, Nevada e Virgínia Ocidental.....................................111

3.1.18.11 Wyoming, Carolina do Norte, Arizona e Alasca..................113

3.1.18.12 Colorado, Kansas, Carolina do Sul e Montana.....................113

3.1.18.13 Flórida, Alabama e Distrito de Colúmbia..............................114

3.1.18.14 Após a decisão da Suprema Corte dos EUA …………….....115

$3.2 \mathrm{O}$ Casamento não é permitido em todo o território nacional.............................116

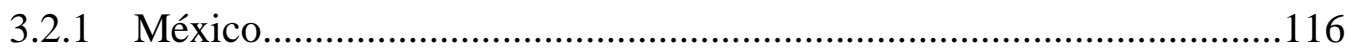

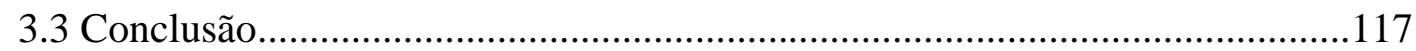

\section{PARTE 2}

4. A FAMÍLIA HOMOAFETIVA NO ORDENAMENTO JURÍDICO

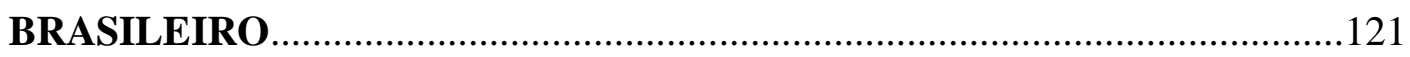

4.1 Uniões homoafetivas e proteção constitucional.................................................124

4.1.1 Princípio da Dignidade da Pessoa Humana...........................................127

4.1.2 Princípio da Igualdade e direito à diferença..........................................128

4.1.3 Princípio da Afetividade...................................................................130

$4.2 \mathrm{O}$ vazio legislativo quanto às uniões homoafetivas..........................................130 


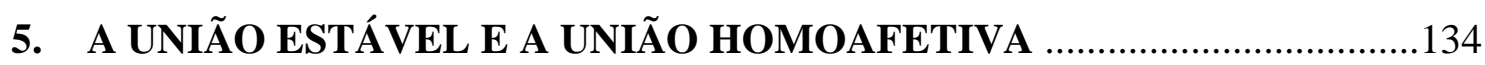

5.1 Evolução da união estável no direito brasileiro..............................................135

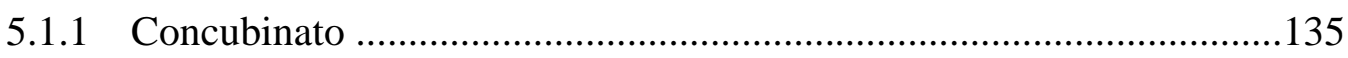

5.1.2 Concubinato como sociedade de fato................................................136

5.1.3 Legislação extravagante em defesa do concubinato............................137

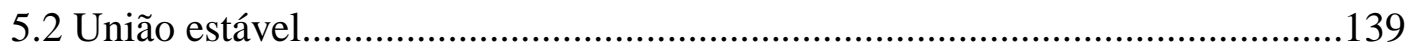

5.3 União homoafetiva e a jurisprudência brasileira.............................................142

5.4 O Supremo Tribunal Federal e o reconhecimento das uniões homoafetivas

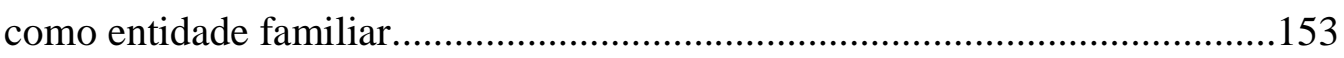

5.5 As decisões judiciais após o julgamento pelo STF da ADI 4277/DF e ADPF

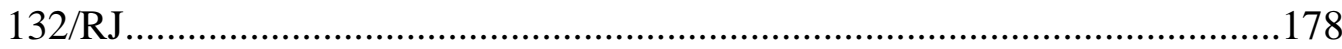

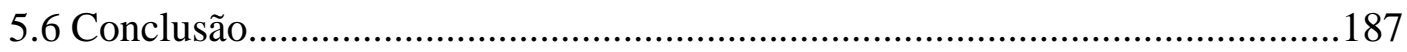

6. O CASAMENTO CIVIL E A UNIÃO HOMOAFETIVA.............................. 198

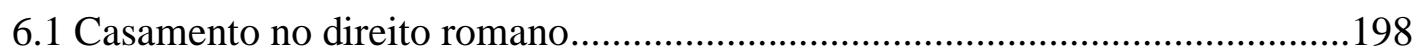

6.2 Casamento no direito canônico........................................................................199

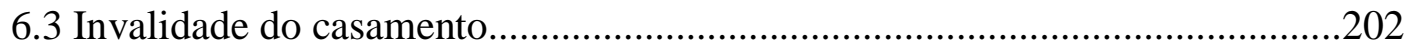

6.4 Configuração da inexistência do casamento.................................................204

$6.5 \mathrm{O}$ reconhecimento pelo STJ do casamento homoafetivo................................212

6.6 As decisões do STF e STJ abalaram a teoria da inexistência do casamento?..234

6.7 Necessidade de mudança do Código Civil e da Constituição Federal?............236

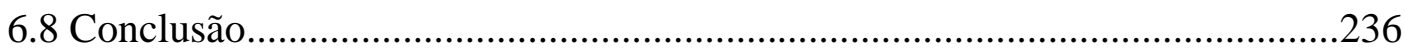

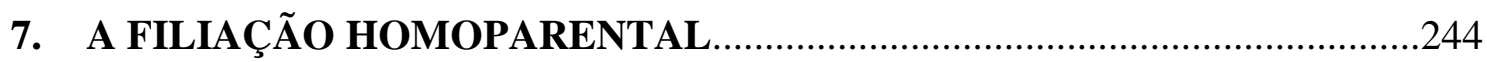

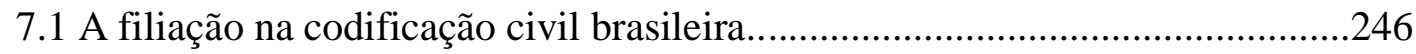

7.2 Reprodução medicamente assistida e os casais homossexuais.......................250

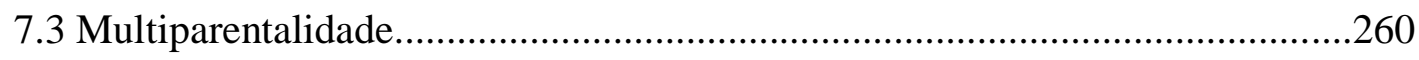

7.4 Reprodução medicamente assistida no direito estrangeiro..............................264

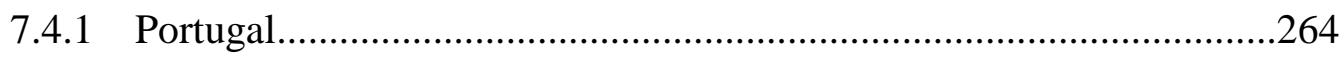




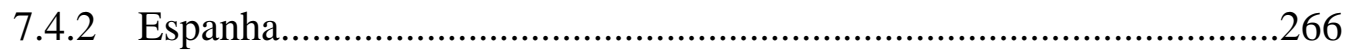

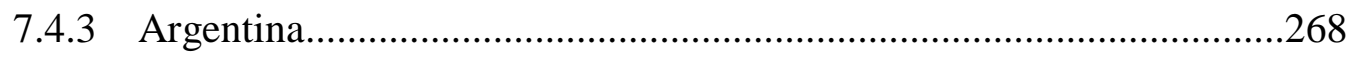

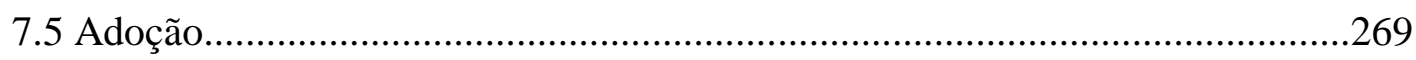

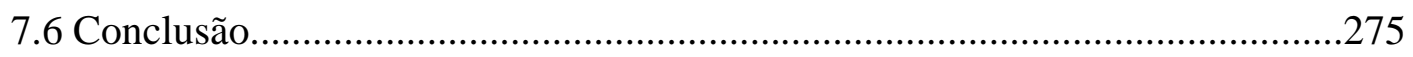

8. ANÁLISE DOS PRINCIPAIS PROJETOS DE LEIS........................................278

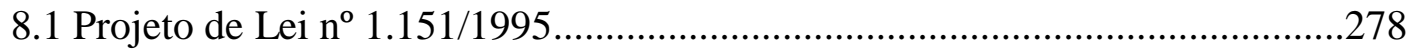

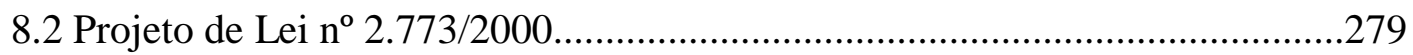

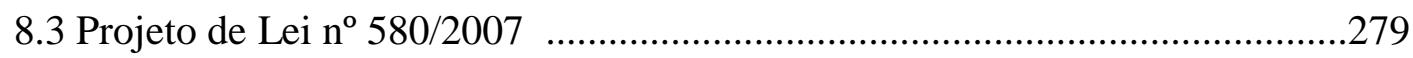

8.4 Projeto de Lei $n^{\circ} 2.285 / 2007$ - Estatuto das Famílias......................................283

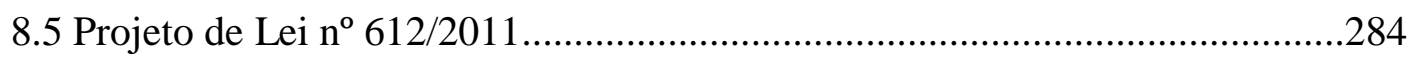

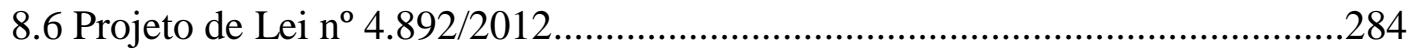

8.7 Projeto de Lei $n^{\circ} 470 / 2013$ - Estatuto das Famílias............................................285

8.8 Projeto de Lei $\mathrm{n}^{\mathrm{o}}$ 6.583/2013 - Estatuto da Família.........................................287

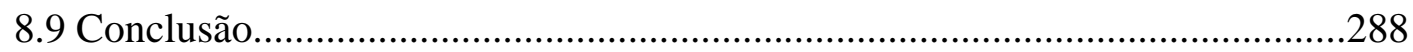

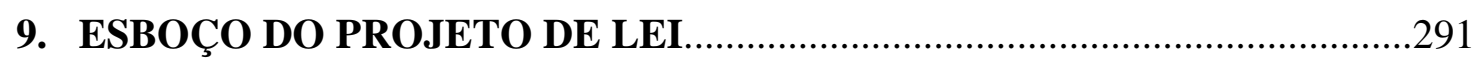

CONCLUSÃO

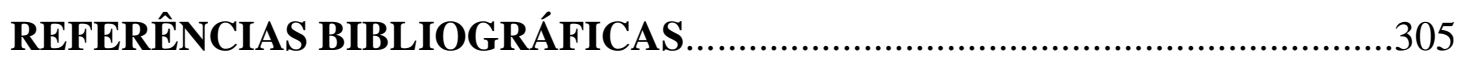




\section{INTRODUÇÃO}

O título do trabalho - "Uniões homoafetivas: da invisibilidade à entidade familiar"- comporta algumas explicações. O termo "invisibilidade", interpretado juridicamente, tem o significado de ser invisível como sujeito de direitos, ou seja, de “inexistência” jurídica. Invisível também na sociedade pode ser entendido como sendo tudo aquilo que existe de fato, mas não é aceito por causar certo desconforto, por ser diferente do estabelecido na sociedade. Neste sentido é que deve ser interpretado o termo "invisibilidade".

Mas ser visível também significa algo mais simples e literal: que as outras pessoas possam lhe ver, pois o que não se vê não existe.

No decorrer da história ocidental, a homossexualidade ora foi aceita, ora foi condenada, ora foi ignorada ou deliberadamente escondida. A partir dos anos setenta, o tema veio à luz do dia e passou a ser abordado com maior ênfase por historiadores e pelo direito.

A noção tradicional de família, para o Direito brasileiro, era aquela formada pelos pais - homem e mulher - unidos por um casamento regulado pelo Estado e seus filhos.

A Constituição Federal de 1988 consagrou a proteção da família em seus artigos 226 e $227^{2}$, sendo que o art. 226 reconhece a proteção de três modalidades de família: a família formada pelo casamento; a família formada pela união estável - ambas fundadas na dualidade de sexos -, ou seja, homem e mulher e a família monoparental, formada por qualquer dos pais e seus descendentes.

No entanto, a família, mutável por natureza, continuou a se modificar e assumiu novas formas antes inconcebíveis aos olhos da lei e dos costumes. Podemos citar como

\footnotetext{
${ }^{2}$ Art. 226, CF: “A família, base da sociedade, tem especial proteção do Estado. $\S 1^{\circ} \mathrm{O}$ casamento é civil e gratuita a celebração. $\S 2^{\circ} \mathrm{O}$ casamento religioso tem efeito civil, nos termos da lei. $\S 3^{\circ}$ Para efeito da proteção do Estado, é reconhecida a união estável entre o homem e a mulher como entidade familiar, devendo a lei facilitar sua conversão em casamento. $\S 4^{\circ}$ Entende-se, também, como entidade familiar a comunidade formada por qualquer dos pais e seus descendentes". Art. 227 caput: "É dever da família, da sociedade e do Estado assegurar à criança e ao adolescente, com absoluta prioridade, o direito à vida, à saúde, à alimentação, à educação, ao lazer, à profissionalização, à cultura, à dignidade, ao respeito, à liberdade e à convivência familiar e comunitária, além de coloca-los a salvo de toda forma de negligência, discriminação, exploração, violência, crueldade e opressão".
} 
exemplos mais polêmicos a família paralela ${ }^{3}$, que se forma desrespeitando o princípio da monogamia e que a jurisprudência vem assegurando benefícios patrimoniais e a família formada por pessoas do mesmo sexo que é o tema de nossa Dissertação.

Assim, algumas questões emergem: o rol de modalidades de família, previsto no artigo 226, da Constituição Federal é taxativo ou meramente exemplificativo?

Outro questionamento que se apresenta é: o casamento entre pessoas do mesmo sexo modificou a Teoria do Casamento Inexistente em nosso país? Estes questionamentos serão analisados no decorrer da Dissertação.

O afeto alçou valor jurídico entrando para o mundo do Direito. A família de hoje deixou de ser essencialmente um núcleo econômico para dar lugar à valorização da existência do afeto nos relacionamentos. Embora a palavra afeto não esteja no texto constitucional, e tampouco no Código Civil, podemos citar alguns exemplos que mostram que a afetividade, a qual une duas pessoas, adquiriu reconhecimento e inserção no sistema jurídico. O primeiro exemplo é o reconhecimento das uniões estáveis como entidade familiar, pois antes somente com o casamento haveria a possibilidade de se constituir família. $\mathrm{O}$ segundo exemplo se refere à equiparação entre as filiações biológica e adotiva, proibindo-se quaisquer discriminações, conforme se observa da leitura dos artigos 227 , $6^{\circ}$, da Constituição Federal e 1.596, do atual Código Civil ${ }^{4}$. Um terceiro exemplo está presente no nosso Código Civil em seu artigo $1.593^{5}$ que admite a filiação socioafetiva, além do parentesco natural e civil. Por fim, um quarto exemplo são as famílias formadas por pessoas do mesmo sexo, que antes eram tidas como sociedade de fato e hoje são entendidas como uma sociedade estruturada no afeto.

De real importância nesta transformação, portanto, foi a Constituição de 1988, uma verdadeira Carta de Princípios, que nos trouxe um novo modo de ver o Direito e, em especial, o Direito de Família. Dentre esses princípios que se aplicam ao Direito de

\footnotetext{
${ }^{3}$ O Projeto do Estatuto das Famílias, PLS no 470/2013, refere-se ao relacionamento familiar paralelo no parágrafo único do artigo 14: "As pessoas integrantes da entidade familiar têm o dever recíproco de assistência, amparo material e moral, sendo obrigadas a concorrer, na proporção de suas condições financeiras e econômicas, para a manutenção da família. Parágrafo único: A pessoa casada, ou que viva em união estável, e que constitua relacionamento familiar paralelo com outra pessoa, é responsável pelos mesmos deveres referidos neste artigo, e, se for o caso, por danos materiais e morais".

${ }^{4}$ Art. 227, § 60 , CF: "Os filhos, havidos ou não da relação do casamento, ou por adoção, terão os mesmos direitos e qualificações, proibidas quaisquer designações discriminatórias relativas à filiação. Art. 1.596, CC. Os filhos, havidos ou não da relação de casamento, ou por adoção, terão os mesmo direitos e qualificações, proibidas quaisquer designações discriminatórias relativas à filiação".

${ }^{5}$ Art. 1.593, CC: "O parentesco é natural ou civil, conforme resulte de consanguinidade ou outra origem".
} 
Família é importante citar: o princípio da dignidade da pessoa humana (artigo $1^{\circ}$, III), princípio da igualdade (artigo $5^{\circ}$ caput), princípio da vedação de discriminações (artigo $3^{\circ}$, IV) e o princípio da liberdade (artigo $5^{\circ}$, caput). Consagra, ainda, o direito à intimidade (artigo $5^{\circ}, X$ ) e como aspecto do exercício desse direito, tem-se a orientação sexual livre de discriminações. ${ }^{6}$

Quanto às uniões de pessoas do mesmo sexo, estas percorreram um longo caminho, desde a inexistência jurídica, passando pelo enquadramento como sociedade de fato, com fundamento no art. 1.363 do Código Civil de 1916 e art. 981, caput, do Código Civil de $2002^{7}$, para a divisão do patrimônio amealhado pelo esforço comum, passando à analogia com a união estável heteroafetiva, até o reconhecimento de uma entidade familiar, pela decisão histórica do Supremo Tribunal Federal em 05 de maio de 2011.

Ao realizarmos um estudo mais profundo, verificamos que o assunto é de real importância e traz diversas consequências jurídicas, além de ser mais comum em nossa sociedade do que imaginamos. Aos poucos, a Doutrina vem se aprofundando no estudo de tal questão. No entanto, o atual sistema jurídico, que rege as questões familiares com base no Código Civil de 2002 encontra-se defasado, pois foi concebido de acordo com as concepções morais da década de 1960. Eis, pois, a necessidade de se adequar essas regras às novas formações de família que não são protegidas pela legislação atual.

A dissertação foi dividida em duas partes. A primeira parte contém os três primeiros capítulos que tratam da homossexualidade na história, dos pré-conceitos sobre a homossexualidade e do casamento homossexual na legislação estrangeira. A segunda parte, engloba os seis últimos capítulos, que tratam respectivamente da família homoafetiva no ordenamento jurídico pátrio, a união estável e a união homoafetiva, o casamento civil e a

\footnotetext{
${ }^{6}$ Art. $1^{\circ}$, III, CF: "A República Federativa do Brasil, formada pela união indissolúvel dos Estados e Municípios e do Distrito federal, constitui-se em Estado Democrático de Direito e tem como fundamentos: III- a dignidade da pessoa humana". Art. $5^{\circ}$, caput: "Todos são iguais perante a lei, sem distinção de qualquer natureza, garantindo-se aos brasileiros e aos estrangeiros residentes no País a inviolabilidade do direito à vida, à liberdade, à igualdade, à segurança e à propriedade, nos termos seguintes". Art. $3^{\circ}$, IV, CF: "Constituem-se objetivos fundamentais da República Federativa do Brasil: IV-promover o bem de todos, sem preconceitos de origem, raça, sexo, cor, idade e quaisquer outras formas de discriminação". Art. $5^{\circ}$, X: "São invioláveis a intimidade, a vida privada, a honra e a imagem das pessoas, assegurado o direito a indenização pelo dano material ou moral decorrente de sua violação".

7 Art. 1.363, CC16: "Celebram contrato de sociedade as pessoas que mutuamente se obrigam a combinar seus esforços ou recursos, para lograr fins comuns". Art. 981, caput, CC02: "Celebram contrato de sociedade as pessoas que reciprocamente se obrigam a contribuir, com bens ou serviços, para o exercício de atividade econômica e a partilha, entre si, dos resultados".
} 
união homoafetiva, a filiação homoparental, análise dos principais projetos de leis e proposta legislativa .

No primeiro capítulo, é estudada a homossexualidade nas civilizações grecoromanas, na Idade Média e finalmente na Idade Moderna até os dias atuais.

No segundo capítulo, são discutidos os vários pré-conceitos sobre a homossexualidade, mostrando, assim, a formação do preconceito e da intolerância.

No terceiro capítulo é feita uma pesquisa sobre a união homossexual em vários países do mundo, mostrando onde tais uniões tem o valor jurídico de casamento.

Adentrando à segunda parte, no quarto capítulo, é abordada a proteção constitucional às uniões homossexuais por meio dos princípios da dignidade da pessoa humana, da igualdade, e da afetividade. O vazio legislativo não significa a ausência de direitos à família homoafetiva, tendo em vista os princípios constitucionais e a ausência de proibição legal.

No quinto capítulo, é estudada a evolução histórica do instituto da união estável heteroafetiva, mostrando as semelhanças dos caminhos percorridos pelas uniões homoafetivas na jurisprudência pátria, culminando com o reconhecimento pelo Supremo Tribunal Federal das mesmas como entidade familiar.

No sexto capítulo, o casamento é visto sob a ótica do direito romano, do direito canônico, passando pela invalidade do casamento e culminando pela configuração da inexistência do casamento para os pares homossexuais. A pergunta que explode é: "a decisão do Supremo Tribunal Federal quanto às uniões homoafetivas, a decisão do Superior Tribunal de Justiça, com relação ao casamento homossexual e a Resolução $N^{\circ}$ 175 do Conselho Nacional de Justiça abalaram a teoria da inexistência do casamento?”.

No sétimo capítulo, a filiação homoparental é tratada sob a ótica da adoção e da reprodução artificial medicamente assistida. É feito, também, um estudo sobre tais institutos na visão do direito estrangeiro.

No oitavo capítulo é feita uma análise dos principais Projetos de Leis sobre o assunto. 
No nono e último capítulo considera-se a necessidade ou não da alteração do Código Civil e da Constituição Federal, com a sugestão de propostas necessárias à adaptação do diploma de 2002 à realidade sociojurídica e à sua harmonização constitucional.

Em cada um destes capítulos há uma conclusão sob o olhar dessa pesquisa feita, conforme sugestão do professor titular Rui Geraldo Camargo Viana no exame de qualificação.

Almeja-se, em suma, com o presente trabalho, contribuir para a minimização da intolerância e do preconceito com relação aos pares homoafetivos, consolidando na legislação as conquistas obtidas por meio dos Tribunais Superiores pátrios. 


\section{PARTE 1}

\section{A HOMOSSEXUALIDADE NA HISTÓRIA}

Uma assertiva, reiteradamente, atribuída a Goethe é que "a homossexualidade é tão antiga quanto a heterossexualidade”. Está presente na história humana, e, portanto, não pode ser ignorada. $^{8}$

Uma atenção especial será dada à história da homossexualidade na Grécia e Roma antigas, passando pela Idade Medieval, Idade Moderna e chegando aos dias atuais.

\subsection{A homossexualidade e a civilização grega}

A homossexualidade era praticada por romanos, egípcios, gregos e assírios. Porém, a homossexualidade tomou maior vulto entre os gregos. Tinha essencialmente características como a intelectualidade, a estética corporal e a ética comportamental. A valorização do belo assumia real importância, não existindo discriminação das relações mantidas entre pessoas do mesmo sexo ou não. Relações homossexuais eram tão frequentes na sociedade grega que podiam ser consideradas mais nobres do que os relacionamentos heterossexuais. ${ }^{9}$

Com o amparo em Michel Foucault, pode-se afirmar que na Grécia, além do culto ao belo, predominava a bissexualidade. Todavia, eles não reconheciam duas espécies de desejos, diferentes ou concorrentes. Diz-se de sua bissexualidade ao pensarmos na livre escolha que faziam entre os dois sexos, porém essa possibilidade não era sentida como uma estrutura dupla, ambivalente e bissexual do desejo. O que os levava a desejar um

\footnotetext{
${ }^{8}$ DIAS, Maria Berenice. União Homoafetiva. O preconceito \& a Justiça, 5. ed. São Paulo: RT, 2011, p. 33.

${ }^{9}$ BRANDÃO, Débora Vanessa Caús. Parcerias Homossexuais. Aspectos Jurídicos. São Paulo: RT, 2002, p. 31-32.
} 
homem ou uma mulher era unicamente o apetite que a natureza tinha implantado no coração do homem para aqueles que são belos, qualquer que seja o seu sexo. ${ }^{10}$

Na Grécia, a homossexualidade se revelava por meio de lendas, mitos, deuses, reis e heróis.

A mitologia grega contém muitos relacionamentos homossexuais. O mais famoso casal masculino é formado por Zeus e Ganimedes. Outro deus com experiências homossexuais foi Apolo, que estava constantemente raptando jovens efebos. Outro célebre caso é o do poderoso Hércules, que amou, entre outros, Adônis, que por sua vez foi seduzido, de forma arrebatadora, por Dionísio, deus do vinho. As mulheres não aparecem nesses mitos de iniciação, nem as mães de todos esses jovens se manifestam sobre tais seduções. Pode-se dizer que a pederastia ocupava um lugar na estrutura social como um ritual sagrado, e que as mulheres não tinham um papel e deviam permanecer subservientes, sem manifestações. ${ }^{11}$

Em Esparta, a relação homossexual era valorizada pelo governo. A homossexualidade espartana era uma consequência lógica da supervalorização do mundo masculino, da guerra e das relações entre homens em geral. Como exemplo da solidariedade e agressividade que a homossexualidade é capaz de produzir no grupo militar que a pratica, podemos citar o "destacamento homossexual" que tinha Felipe da Macedônia e que morreram todos na batalha de Queronéia, assombrando quem os viram lutar. Isto porque, cada um deles ao lutar contra o inimigo, defendia seu par, sua própria vida, seu prestígio social ante aquele com quem compartilhava seus sentimentos. Não é necessário destacar a agressividade de quem trata de vingar a morte do amante nas mãos do inimigo ${ }^{12}$.

Adilson José Moreira citando Murray (Homosexualities) e Boswell (Same-sex unions in premodern Europe), ambos da Universidade de Chicago, discorre sobre outro exemplo do valor cultural dessas uniões que é a exaltação do "bando sagrado de Tebas", constituído por um grupo de guerreiros formados por duplas de 150 amantes, criado pelo

\footnotetext{
${ }^{10}$ FOUCAULT, Michel. História da sexualidade. O uso dos prazeres. Vol. 2. Trad. Maria Thereza da Costa Albuquerque. Rio de Janeiro: Graal, 1984, p. 168.

${ }^{11}$ SPENCER, Colin. Homossexualidade: uma história. 2. ed. Rio de Janeiro: Record, 1995, p. 28-29.

${ }^{12}$ BRANDÃO, Débora Vanessa Caús. Parcerias Homossexuais. Aspectos Jurídicos. São Paulo: RT, 2002, p. 32.
} 
general Górgidas. Tais guerreiros lutavam junto com os outros batalhões, porém, tendo em vista seu grande sucesso, passaram a atuar como um batalhão de choque sob a direção de Pelópidas. O seu sucesso transformou a cidade de Tebas na mais poderosa força militar da época. Tebas, que era a capital da Beócia, tinha fama de incentivar publicamente o casamento entre homens adultos e rapazes. A formação deste batalhão baseava-se na ideia bastante difundida entre os gregos de que o forte vínculo existente entre os amantes seria um elemento decisivo no campo de batalha. $\mathrm{O}$ amor existente entre eles faria com que um defendesse o outro a qualquer custo. A história do bando de Tebas está relacionada também à história de Pelópidas e Epaminondas. Epaminondas era um político destacado e também um grande estrategista militar, o que levou Tebas a vencer o poderoso exército espartano na batalha de Leutra e estabeleceu a hegemonia militar tebana no Peloponeso. $\mathrm{O}$ relacionamento de Pelópidas e Epaminondas é também um dos mais admirados no mundo grego. $^{13}$

Débora Vanessa Caús Brandão, citando Caroline Mécary (Droit et homosexualité), ensina que, com relação à homossexualidade, além da estética havia todo um ritual envolvendo a transmissão e a aquisição de sabedoria. Pode-se citar como maior exemplo o filósofo Platão e seus preceptores. Os efebos eram adolescentes que buscavam o mestre para serem iniciados na arte da retórica e da oratória. Ser escolhido pelo preceptor era motivo de muita honra e assim os jovens aprendizes deveriam se submeter a favores sexuais. Percebe-se que havia um motivo para que os preceptados servissem seus preceptores: a crença de que essa prática aumentaria suas habilidades políticas e militares, além de ter como fundamento a transmissão de um saber e de uma educação refinada. ${ }^{14}$

O relacionamento entre mulheres talvez tenha existido principalmente na cidade de Esparta, onde havia rituais de iniciação de garotas por mulheres mais velhas de forma semelhante aos existentes entre homens e rapazes. A poesia lírica também apresenta inúmeras celebrações dos relacionamentos entre pessoas do mesmo sexo. A poesia de Safo, e a celebração do amor entre mulheres surgiram na ilha de Lesbos, onde jovens garotas competiam pelos prêmios atribuídos às mais belas. Safo exercia a liderança de um grupo de mulheres e garotas que compartilhavam com ela o mesmo gosto estético e o interesse

\footnotetext{
${ }^{13}$ MOREIRA. Adilson José. União Homoafetiva. A Construção da Igualdade na Jurisprudência Brasileira. 2. ed. Curitiba: Juruá, 2012, p. 305.

${ }^{14}$ BRANDÃO, Debora Vanessa Caús. Parcerias Homossexuais. Aspectos Jurídicos. São Paulo: RT, 2002, p. 33.
} 
por mulheres. Suas poesias despertavam a admiração de muitos gregos, entre eles o grande filósofo Platão. Seus poemas tiveram grande popularidade no mundo grego da época. ${ }^{15}$

O famoso discurso de Aristófanes em, "O banquete" de Platão, procura avançar na explicação da natureza do amor masculino, por meio da explicação da natureza humana. Aristófanes refere-se a um passado mítico no qual havia três gêneros, o masculino, o feminino e o andrógino, então desaparecido. Tais seres tinham a forma inteiriça, como se fosse dois seres humanos, com seus membros em dobro, ligados um ao outro. Por tentarem investir contra os deuses, eles foram partidos ao meio a fim de que se tornassem mais fracos e dependentes. As partes separadas pelos deuses sempre procuravam unir-se a fim de restaurar o estado anterior. As partes masculinas procuravam umas às outras, como também as partes femininas. As partes que derivavam dos seres andróginos procuravam exclusivamente o seu oposto. $\mathrm{O}$ amor não seria nada mais do que essa reminiscência de uma forma anterior da natureza humana que motiva os indivíduos a buscarem a sua metade. Aristófanes se refere a Pausânias e Agatão, dois personagens do diálogo, como um exemplo de duas almas que procuram manter-se juntas em todos os momentos. ${ }^{16}$

Ensina a professora Adriana Caldas do Rego Freitas Dabus Maluf que Platão desgostoso com a execução de Sócrates, de quem foi discípulo, empreendeu várias viagens, sendo que em Siracusa conheceu o nobre Díon com quem desenvolveu calorosa amizade, evidenciando sua tendência homossexual. De acordo com relatos históricos, Platão apaixonou-se por Dion e concebeu o que se conhece por "amor platônico". Um tema de grande importância no pensamento de Platão é o papel do amor como força educacional. Em Creta, se os moços entrassem na idade viril e não encontrassem um amante, isso era considerado uma vergonha ${ }^{17}$.

Assim, o homoerotismo dentro do mundo grego tinha algumas características preponderantes. A paiderastia, amor por rapazes, se dava entre um homem mais velho, o erastes ou amante, e o eromenos, ou amado. A função do erastes era servir como modelo

\footnotetext{
${ }^{15}$ MOREIRA. Adilson José. União Homoafetiva. A Construção da Igualdade na Jurisprudência Brasileira. $2^{\text {a }}$ ed. Curitiba: Juruá, 2012, p. 300-304.

${ }^{16}$ MOREIRA. Adilson José. União Homoafetiva. A Construção da Igualdade na Jurisprudência Brasileira. $2^{\mathrm{a}}$ ed. Curitiba: Juruá, 2012, p. 302-303.

${ }_{17}$ MALUF, Adriana Caldas do Rego Freitas Dabus Maluf. Novas Modalidades de Família na PósModernidade. São Paulo: Atlas, 2010, p. 130.
} 
de coragem, sabedoria e virtude cívica para o eromenos, ou amado, jovem cuja atração se baseava na beleza física, no fato de ter um futuro moral, intelectual e militar promissor. ${ }^{18}$

\subsection{A homossexualidade e a civilização romana}

Com relação às uniões entre pessoas do mesmo sexo, parece que a atitude dos romanos foi mais ambígua do que a dos gregos. É certo que os romanos expressavam o interesse sexual tanto por homens quanto por mulheres, mas os relacionamentos entre homens não tinham o mesmo valor cultural presente na cultura grega. No período republicano, tais relações eram vistas como relações de dominação, havendo uma correlação entre a conquista militar e a dominação sexual. Havia uma aceitação dos relacionamentos entre homens livres e escravos, sendo que cabia aos escravos a função de ser penetrado nas relações sexuais. Em uma sociedade na qual a mulher ocupava um papel de quase completa inferioridade social, as funções de gênero serviam como parâmetro para o julgamento das práticas sexuais. Ser penetrado significava ser posto no lugar de uma mulher, o que era indigno para um cidadão romano. Acusações de comportamento sexual passivo eram utilizadas para arruinar carreiras políticas, mas não se encontram acusações contra homens que tinham o papel ativo dentro das relações sexuais. ${ }^{19}$

Assim, em Roma, a homossexualidade era tolerada. Várias figuras célebres do Império Romano viveram relações homossexuais e bissexuais. Júlio César teve um caso notório com Nicomedes, Rei de Bitínia, embora também fosse conhecido como "mulher de todos os homens e homem de todas as mulheres". Júlio César tinha fama de sedutor de mulheres, entre elas, a célebre Cleópatra. No entanto, algumas regras peculiares apareceram na Roma clássica. A passividade na relação era rechaçada. A sexualidade masculina romana estava fundamentada no princípio da subjugação. Grécia e Roma eram sociedades patriarcais baseadas na erotização da violência, da hierarquia e do poder sobre os mais fracos. A ideia das relações homossexuais gregas, de se cortejar um menino, convencendo-o da honra e honestidade das intenções do amante, era extremamente

\footnotetext{
${ }^{18}$ MOREIRA. Adilson José. União Homoafetiva. A Construção da Igualdade na Jurisprudência Brasileira. $2^{\mathrm{a}}$ ed. Curitiba: Juruá, 2012, p. 300.

${ }^{19}$ MOREIRA. Adilson José. União Homoafetiva. A Construção da Igualdade na Jurisprudência Brasileira. $2^{\mathrm{a}}$ ed. Curitiba: Juruá, 2012, p. 305-306.
} 
repugnante ao espírito da Roma antiga, uma vez que esse comportamento denotava uma submissão estranha à essência da virilidade. ${ }^{20}$

O macho romano se via como um dominador agressivo e acreditava que, quando forçava outros a se submeterem, estava lhes proporcionando prazer. Entre os romanos o amor por rapazes livres era proibido, tendo em vista que a sexualidade deles estava intimamente ligada à dominação. Portanto, era-lhes permitido somente o amor por rapazes escravos. A célebre frase de Sêneca, o Velho, segundo a qual "serviços sexuais constituem um crime para os nascidos livres, uma necessidade para os escravos e um dever para os libertos" representa muito bem essa visão. Porém, com a conquista da Grécia Antiga pelo Império Romano e a adoção da cultura helênica, passou o Império Romano a ter suavizada a ideia de virilidade baseada na dominação, tornando-se prática comum, embora legalmente vedada, o amor por rapazes baseados na corte, na conquista dos tempos da Grécia Clássica, não se condenando o amor masculino, apenas a sexualidade passiva. É importante relembrar que esta era tida como uma conduta feminina, e o homem que assim agisse era visto como alguém que abria mão de sua masculinidade, sendo portanto equiparado às mulheres como um "cidadão de segunda classe". No entanto, essa visão do sexualmente passivo mostrou-se relativa no Império Romano, quando o homem em questão tinha outras atitudes vistas como eminentemente masculinas, por exemplo, a arte da guerra. Exemplo clássico dessa afirmação foi o notório Imperador Júlio César. César, contudo, não era apenas o chefe de uma força conquistadora romana; sua potência estava ligada a suas proezas no campo de batalha. Um homem com a reputação que tinha, acreditava-se, podia se permitir resvalar ocasionalmente num papel passivo e ainda assim continuar um homem. ${ }^{21}$

No início da República Romana as relações homossexuais entre homens livres eram punidas até com a morte pela lei Scantinia. Porém, ao que parece, essa lei proibia certas formas de contato sexual, como a pederastia, que era considerada uma prática grega degenerada e também os casos em que o cidadão exercia um papel passivo. Assim, não havia qualquer restrição legal quanto à utilização sexual de escravos homens pelo seu dono.

20 CHAVES, Marianna. Homoafetividade e Direito. Proteção Constitucional, Uniões, Casamento e Parentalidade. 2. ed. Curitiba: Juruá, 2012, p. 55-56.

${ }^{21}$ VECCHIATTI, Paulo Roberto Iotti. Manual da Homoafetividade. Da possiblidade jurídica do casamento civil, da união estável e da adoção por casais homoafetivos. 2. ed. São Paulo: Gen, Método, 2012, p. 7-8. 
Os costumes gregos foram sendo gradualmente aceitos pela sociedade romana nos anos finais da república e no início do império. A prática da pederastia tem o seu apogeu durante o reinado do Imperador Adriano, que compartilhava uma paixão para com os garotos. É famoso seu amor pelo jovem grego Antínoo. Adriano era trinta e quatro anos mais velho que Antínoo (um adolescente), enquadrando-se a relação no modelo pederástico da Grécia Clássica. Apesar de Adriano ter tido numerosas amantes e uma mulher, a imperatriz Sabina, Antínoo era seu amante favorito.

Em outubro de 130, durante uma visita ao Egito, Antínoo morreu afogado no rio Nilo, mas as circunstâncias em que o evento ocorreu são pouco claras. Segundo as fontes da época, após a sua morte Adriano teria chorado desesperadamente e decretou a sua deificação. O imperador ordenou a construção de uma nova cidade perto do local da sua morte, Antinoópolis. Por todo o Império Romano foram erguidas numerosas estátuas de Antínoo e na parte oriental do Império levantaram-se templos dedicados ao jovem. Sabiase que, após sua morte por afogamento no ano 130, o imperador construiu uma tumba para ele no Egito, chegando a identifica-lo com o deus Osíris.

Em 2002, arqueólogos descobriram, na vila de Tivoli (Itália), resquícios de um templo construído pelo Imperador Adriano (117 a 138) em homenagem a seu amante Antínoo. Em Tivoli, já havia sido descoberta no século 18 uma estátua de Antínoo, mantida hoje no museu do Vaticano. ${ }^{22}$

Adriano viveu ainda mais oito anos. Após sua morte a sua relação com Antínoo foi utilizada contra si. Os primeiros autores cristãos também criticaram esta relação, que para eles era um exemplo da amoralidade patente do paganismo. ${ }^{23}$

De acordo com o historiador John Boswell, muitos relacionamentos homossexuais eram permanentes e exclusivos. As uniões informais predominavam nas classes inferiores, porém o casamento entre homens ou entre mulheres era legal entre as classes mais altas. Existem evidências de que os romanos do período republicano davam às uniões homossexuais o mesmo status das uniões heterossexuais. O citado historiador argumenta que o biógrafo do imperador Elegabalus descreve que após seu casamento com um atleta,

22 Templo feito por imperador romano a seu amante é achado na Itália. Disponível em: http://www1.folha.uol.com.br/folha/ciencia/ult306u7649.shtml Acesso em 29 jan. 2014.

Homossexualidade na Roma Antiga. Antínoo Disponível em: http://pt.wilkipedia.org/wiki/Homossexualidade_na_Roma_Antiga;http://pt.wikipedia.org/wiki/Antinoo Acesso em 29 jan. 2014. 
quaisquer homens que ambicionavam cargos na corte romana procuravam ter um marido ou fingiam que tinham um relacionamento com uma pessoa do mesmo sexo. O mesmo autor cita também várias fontes literárias que mencionam o enlace matrimonial entre pessoas do mesmo sexo, cerimônias que seguiam os mesmos procedimentos observados nos casamentos entre pessoas de sexos opostos, sendo que o status civil dessas pessoas era alterado em função dessas uniões. Nero casou em cerimônia pública com o ritual próprio dos casamentos legais por duas vezes. Um de seus esposos, Sporus o acompanhava nas funções públicas, tendo permanecido com Nero durante seu reinado e estiveram juntos até a morte. ${ }^{24}$

Esta é uma visão histórica do casamento homossexual em Roma, não é jurídica afirmaram-me o Professor Álvaro Villaça Azevedo e o Professor Rui Geraldo Camargo Viana.

Pesquisando a visão jurídica na biblioteca da Universidade de Camerino (Itália), deparei-me com o livro "Ubi Venus Mutatur" Omosessualità e Diritto Nel Mondo Romano, de autoria de Danilo Dalla. O autor argumenta que o escasso interesse jurídico se funda na aversão pelo tema, sendo, até hoje, limitadas as pesquisas sobre o assunto. A lacuna e a atualidade do tema solicitam a pesquisa jurídica, sem preconceitos ou condicionamentos. $\mathrm{O}$ autor divide seu livro em mundo pagão e mundo cristão, mas deixa claro que nem sempre é de todo válida para o direito a equação entre época pagã e tolerância e cristianismo e repressão. Refere-se a aspectos jurídicos do homoerotismo permitido entre patrão e servo. Sendo que o termo servo pode-se referir tanto ao escravo quanto à escrava. Uma primeira limitação vem de uma norma vigente à época de Vespasiano com relação aos escravos de ambos os sexos que deveriam ser vendidos com o pacto de não serem prostituídos. Caso o patrão desrespeitasse o pacto o escravo deveria ser liberto.

Com relação ao matrimônio homossexual, Danilo Dalla, referindo-se à afirmação do historiador Boswell, citada acima, afirma tratar-se exclusivamente de fonte histórica sem qualquer embasamento em fontes jurídicas. Referindo-se à união entre Nero e Sporo, não entende ser de interesse jurídico, pois aparenta ser um envolvimento entre um homem livre e um escravo. Concluindo deixa claro que tais episódios podem ser relevantes para os

\footnotetext{
${ }^{24}$ BOSWELL, John. Christianity, Social Tolerance, and Homosexuality. Chicago and London: University of Chicago Press, 1981, p. 82.
} 
costumes, mas não deixaram traços no direito como sendo matrimônio. Na verdade, os romanos tiveram sempre a convicção de que o matrimônio deveria ser pressuposto a existência de pessoas de sexos diversos. ${ }^{25}$

Em artigo da Revista Labeo de Direito Romano, Angela Romano ${ }^{26}$ referindo-se à tradução italiana do já clássico J. Boswell, "Cristianesimo, tolleranza e omosessualità", e aos autores Danilo Dalla, "Ubi Venus mutatur. Omosessualità e diritto nel mondo romano" e E. Cantarella, "Secondo natura. La bisessualità nel mondo antico," faz uma reflexão sobre a complexidade do emaranhado de mecanismos econômicos, escolhas políticas, propostas culturais e religiosas que produzem ou acentuam a segregação sobre o tema. Um dos nós ainda não totalmente resolvidos na história da cultura ocidental é o do reconhecimento do contexto social em que a homossexualidade assume uma condição negativa socialmente e juridicamente pela primeira vez. Parte da premissa de que no mundo antigo, em especial na Grécia, a homossexualidade e a bissexualidade conviviam naturalmente, porém, a transgressão era representada pela passividade na vida adulta e que comportava sanções sociais e jurídicas com relação à prostituição.

Com relação à sexualidade romana, a definição era "sexualidade do estupro" em que a homossexualidade ativa era lícita se o objeto sexual fossem as mulheres, os inimigos e os escravos. A partir do século III a.C. o Estado protege os jovens de eventuais estupros, primeiramente impondo uma multa pela via administrativa e depois mediante a "Lex Scantina o Scatinia”. Porém, a crise geral de valores no fim da República estremeceu o mito da virilidade tendo em vista a notória homossexualidade passiva de César, não comportando sanções sociais, mas talvez um sarcasmo tolerante. Por fim, houve o recrudescimento, à época de Justianiano da pena de morte para aqueles que praticassem atos homossexuais. Em um passado recente viu-se a patologização e a criminalização da homossexualidade e os primeiros reconhecimentos pelo direito da convivência entre os pares homossexuais, sem, contudo, conseguir conter as manifestações homofóbicas.

Desta forma, temos que concordar que não há traços jurídicos sobre o casamento homossexual no direito romano, constituindo apenas relatos históricos até o presente momento.

\footnotetext{
${ }^{25}$ DALLA, Danilo. Ubi Venus Mutatur. Omosessualità e Diritto nel Mondo Romano. Milano: Dtt. A. Giuffrè Editore, 1987, p. 3-41, 63-69.

${ }^{26}$ ROMANO, Angela. Omosessualità, Amore e Potere Nella Società Romana. Labeo. Rassegna di Diritto Romano. Jovene - 36(1990) 2: Napoli, p. 301-307.
} 
Dois editos, no período justinianeu, trataram da questão homossexual no Império com bastante rigor. Roma assume, a partir de então, posicionamento contrário às práticas homossexuais, E será esta a orientação a ser seguida durante as Idades Média e Moderna. No Edito, ou Novela 77 (ano 538), condenam os homens que atuam contra naturam. Primeiro deve-se admoesta-los, mas, devem-se aplicar as penas se persistem em seu vício. A condenação refere-se ao castigo de Sodoma e Gomorra e às calamidades públicas que os homossexuais podem trazer ao Estado, como consequência de seu comportamento. $\mathrm{Na}$ Novel 141 (ano 548), volta-se a condenar os atos homossexuais. É um edito que, dentro de um clima quaresmal, propõe o arrependimento, mas ameaça com penas extremas em casos de falta de conversão. Enquanto os editos anteriores centravam-se na prostituição homossexual e no abuso dos jovens, os editos de Justiniano condenam indiscriminadamente todo ato homossexual. ${ }^{27}$

A Roma imperial foi palco de uma série de transformações culturais, dentre elas a crescente influência de correntes filosóficas na vida cultural da sociedade. O pensamento estoico teve proeminência particular na sociedade romana. Foi um processo responsável pela desvalorização da bissexualidade e uma valoração da sexualidade para o casamento e a procriação. Os pensadores estoicos incentivavam os homens a canalizarem e controlarem os seus impulsos sexuais como forma de controle e refinamento espiritual. Tal movimento filosófico criou as bases que possibilitaram a adoção do cristianismo como religião predominante no império romano. Essa nova doutrina religiosa, com ênfase no casamento procriativo, instituiu a condenação moral da homossexualidade. O cristianismo também tinha como base a dominação masculina, mas a virilidade não era mais identificada com a agressividade sexual, e sim com controle e a abstinência sexual. No entanto, para alguns autores cristãos e pagãos, as uniões homossexuais ainda apareciam como um ideal de amor romântico nesse período histórico. ${ }^{28}$

\footnotetext{
${ }^{27}$ BRANDÃO, Debora Vanessa Caús. Parcerias Homossexuais. Aspectos Jurídicos. São Paulo: RT, 2002, p. 34-35.

28 MOREIRA. Adilson José. União Homoafetiva. A Construção da Igualdade na Jurisprudência Brasileira. 2. ed. Curitiba: Juruá, 2012, p. 307-308.
} 


\subsection{A homossexualidade na Idade Média}

Com uma inequívoca influência da religião judaica, a religião cristã tomou como paradigma para o desenvolvimento da fé em Cristo muitos dos preceitos dessa crença. Os apóstolos tinham como base muitas das determinações do "Código Sagrado do Levítico", repetindo, assim, a maioria de suas disposições e, consequentemente, de suas condenações. $^{29}$

Com certeza, o maior preconceito contra a homossexualidade provém das religiões. Porém, na história das religiões há registro de que a homossexualidade era permitida. Nos templos da Fenícia, Mesopotâmia, Egito, Índia, o ato sexual fazia parte do culto religioso praticado com os homens que eram devotos. Os deuses e deusas das religiões politeístas tinham relações sexuais com ambos os sexos.

Porém, com o advento do cristianismo, a influência greco-romana se dissipou e o mito Sodoma e Gomorra ganhou força, especialmente nas religiões judaico-cristãs, para se transformar em um dos principais argumentos dos que são contrários às práticas homossexuais. Com o advento do cristianismo o sexo passa a ser visto como pecado e apenas admitido no âmbito matrimonial e exclusivamente para procriação, visando à formação familiar. Assim, a monogamia e a virgindade para as mulheres passam a ser valorizadas como símbolos de virtude e de pureza. ${ }^{30}$

Na Idade Média, a homossexualidade continuava presente nos mosteiros e nos acampamentos militares. Porém, era a Igreja, por meio da Santa Inquisição, a maior perseguidora dos homossexuais, classificando como pecado qualquer prática sexual que não se destinasse à procriação.

De acordo com o pensamento de São Tomás de Aquino (século XIII), a Igreja classificava os pecados em secundum naturam e contra naturam, sendo estes últimos os

\footnotetext{
29 VECCHIATTI, Paulo Roberto Iotti. Manual da Homoafetividade. Da possiblidade jurídica do casamento civil, da união estável e da adoção por casais homoafetivos. 2. ed. São Paulo: Gen. , Método, 2012, p. 21.

${ }^{30}$ DIAS, Maria Berenice. União Homoafetiva. O preconceito \& a Justiça. 5. ed. São Paulo: RT, 2011, p.36.
} 
que excluíam a possibilidade de procriação, considerados muito graves e, por isso, levavam à condenação dos fiéis. ${ }^{31}$

Segundo Paulo Roberto Iotti Vecchiatti, um dos principais motivos históricos para a condenação da homossexualidade foi a baixa expectativa de vida da população da Europa Ocidental durante a ascensão da fé cristã. Em Roma, isso se caracterizou pelo constante estado beligerante de seu Império, o que causava muitas mortes, onde cada mulher precisaria gerar cinco filhos, em média para que fosse mantida a estabilidade da população romana. Além disso, a peste bubônica dizimou aproximadamente um terço da população europeia da época, e tornou a heterossexualidade, acima de tudo, necessária. Assim, faz sentido que Justiniano tenha baixado duas leis anti-homossexuais, uma antes e outra depois de ter havido, no ano de 542, uma epidemia de peste bubônica. ${ }^{32}$

A sacralização do casamento aconteceu na Idade Média, pois, sem perder o seu viés patrimonial, foi transformado em sacramento. Somente as uniões devidamente abençoadas pela Igreja eram válidas, firmes e indissolúveis. O ato sexual foi reduzido à fonte de pecado. A virgindade era cultuada como um estado mais abençoado do que o próprio casamento, e o sexo ligado ao prazer estava associado à noção de impureza, transgressão, conduta pecaminosa, mesmo dentro do casamento. ${ }^{33}$

Esse novo pensamento social consolidado na Idade Média, em vez de expurgar a expressão do amor entre pessoas do mesmo sexo, acabou fazendo com que ele fosse realizado às escondidas, relegado à invisibilidade.

\footnotetext{
${ }^{31}$ BRANDÃO, Debora Vanessa Caús. Parcerias Homossexuais. Aspectos Jurídicos. São Paulo: RT, 2002, p.35.

${ }_{32}$ VECCHIATTI, Paulo Roberto Iotti. Manual da Homoafetividade. Da possiblidade jurídica do casamento civil, da união estável e da adoção por casais homoafetivos. 2. ed. São Paulo: Gen, Método, 2012, p. 23.

${ }^{33}$ DIAS, Maria Berenice. União Homoafetiva. O preconceito \& a Justiça. 5. ed. São Paulo: RT, 2011, p.38.
} 


\subsection{A homossexualidade na Idade Moderna e nos dias atuais}

$\mathrm{Na}$ Idade Moderna, a homossexualidade permaneceu com as mesmas peculiaridades de após a Idade Média: a vida transcorria naturalmente, como se tais relações inexistissem, isto é, fossem invisíveis.

No período renascentista várias figuras célebres como Leonardo Da Vinci, Michelangelo, Shakespeare, Caravaggio, entre outros, tiveram notórias paixões por pessoas do mesmo sexo. ${ }^{34}$

Com o advento da visão humanista, oriunda da Itália do século XV, os valores da Grécia Clássica foram redescobertos. Filósofos pregavam abertamente pela validade do amor masculino. Contudo, a condenação de tais atos não deixou de crescer nesse período. Em verdade, as autoridades faziam vista grossa em muitos casos, só penalizando aqueles que não escondiam seus relacionamentos homossexuais da comunidade em geral, especialmente entre as classes mais baixas, pois a nobreza e o clero contavam, como sempre, com maior benevolência do Estado.

No século XVII, o modelo econômico capitalista começou a ganhar força, com o estímulo da competitividade entre os homens, o que passou a inibir qualquer contato mais amistoso, especialmente amoroso, entre eles. Passou-se a estimular o desenvolvimento de uma sociedade cada vez mais consumista, o que fez com que o amor homossexual fosse visto como um entrave ao consumismo, visto que a família formada por pessoas do mesmo sexo não teria capacidade de gerar descendentes.

Mesmo a visão iluminista, que via na liberdade sexual uma forma de atingir o progresso, a ordem e a felicidade, condenou com veemência o amor homossexual. Outro fator foi que no século XVIII acreditava-se que o homem tinha apenas uma limitada quantidade de sêmen em seu corpo. Assim, a sexualidade homossexual passou a ser ainda

${ }^{34}$ CHAVES, Marianna. Homoafetividade e Direito. Proteção Constitucional, Uniões, Casamento e Parentalidade. 2. Curitiba: Juruá, 2012, p. 57. 
mais condenada, pois se entendia que ela gastava a semente da vida de forma inútil, ou seja, não procriativa. ${ }^{35}$

Ensina Maria Berenice Dias que sempre foi muito maior a rejeição à homossexualidade masculina por haver perda de sêmen. $\mathrm{O}$ relacionamento entre mulheres era considerado mera lascívia, como se a sexualidade desta natureza fosse menos perigosa. Outro fator relevante é que tanto para as sociedades antigas, como para as mais modernas, o que se passa no âmbito feminino não é valorizado. Esta desatenção às lésbicas decorre da própria discriminação de que até hoje são alvo as mulheres. A prática sexual feminina sempre foi proibida. A mulher devia manter-se virgem até casar, como prova de sua pureza e honestidade. Depois do casamento, precisava submeter-se ao desejo masculino e suportar as relações sexuais, sem poder sequer evitar a gravidez. Assim, a Igreja Católica, proíbe o uso de contraceptivos, mesmo em uma época em que a disseminação da AIDS adquire dimensões assustadoras. ${ }^{36}$

A partir do século XIX, pode-se dizer que a sociedade passou a ser menos intolerante em relação à homossexualidade. Dentro deste panorama mais liberal existente entre os séculos XIX e XX, fora o meio cultural e as artes, outra seara bastante importante foi a psicanálise, pois com a evolução do pensamento freudiano, levou a um juízo distinto da homossexualidade, sendo vista como um comportamento diferente dos outros, mas longe de ser considerada perversão ou doença. Apesar de esta relativa abertura, não raros eram os casos em que a homossexualidade era considerada crime nos códigos penais de diversos países, mantendo alguns, até hoje, tal condenação. ${ }^{37}$

Apesar desta tolerância não se impediu que milhares de homossexuais fossem assassinados nos campos de concentração nazistas ao lado de judeus e ciganos. Assim, o novo Estado, na Alemanha, é dotado de um código penal cujo parágrafo 175 estipula que "luxúria contra o que é natural, realizada entre pessoas do sexo masculino ou entre o homem e o animal, é passível de prisão; pode acarretar a perda de direitos civis".

\footnotetext{
35 VECCHIATTI, Paulo Roberto Iotti. Manual da Homoafetividade. Da possiblidade jurídica do casamento civil, da união estável e da adoção por casais homoafetivos. 2. ed. São Paulo: Gen, Método, 2012, p. 25-27.

${ }^{36}$ DIAS, Maria Berenice. União Homoafetiva. O preconceito \& a Justiça. 5. ed. São Paulo: RT, 2011, p.38-39.

37 CHAVES, Marianna. Homoafetividade e Direito. Proteção Constitucional, Uniões, Casamento e Parentalidade. $2^{\mathrm{a}}$ ed. Curitiba: Juruá, 2012, p. 58.
} 
Os efeitos do endurecimento do parágrafo 175, crime de luxúria, não demoraram a aparecer: as investigações e as perseguições se multiplicaram para encontrar homossexuais conhecidos ou presumidos. Em todos os casos a pena era de prisão de três meses a dez anos, em caso de luxúria com agravantes.

Em discurso feito em 18 de fevereiro de 1937, o Reichsführer SS Himmler ${ }^{38}$ declarou, ao falar sobre homossexuais e o suposto número de homossexuais na população, que "se continuarmos assim, nosso povo corre o risco de ser aniquilado por essa praga". Os homossexuais são considerados indivíduos não reprodutores e, assim, como podem assegurar a perenidade da raça? Por esse discurso, a condenação da homossexualidade não parece mais responder a uma exigência moral, mas sim à necessidade de preservar a raça. Começa, então, o cadastramento dos homossexuais na Central do Reich para reprimir a homossexualidade e o aborto em Berlim. ${ }^{39}$

Os prisioneiros eram classificados com uma numeração de matrícula, e acima desta um triângulo feito de tecido colorido. Um triângulo de poucos centímetros de lado, usado com uma ponta para baixo e costurado na camisa, na altura do coração. A cor dependia do motivo da detenção. O vermelho para os prisioneiros políticos, o preto dos resistentes ao trabalho, o verde dos criminosos profissionais e o rosa para estigmatizar os homossexuais.

Além disso, os homossexuais eram presas preferidas especialmente para as experiências do médico dinamarquês Carl Vaerner. No final de 1944, esse clínico geral, nazista convicto, começou a testar tratamentos de "inversão de polaridade sexual" com os homossexuais, por meio do implante de uma glândula artificial na virilha do indivíduo para liberar hormônio nos testículos. O objetivo era inverter a preferência sexual de suas cobaias. $^{40}$

Em 1969, os tumultos de Stonewall, marcados por diversos conflitos entre a polícia estadunidense e homossexuais, tiveram grande destaque na mídia. Os policiais

\footnotetext{
${ }^{38}$ Reichsführer-SS foi um título especial da SS, que existiu entre 1925 a 1945. Era equivalente à patente de marechal de campo na Wehrmacht. Apenas cinco pessoas detiveram o título de Reichsführer-SS, e Heinrich Himmler (1929-1945) foi um desses. Disponível em: http://pt.wikipedia.org/wiki/Reichsf\%C\%BChrer-SS. Acesso em 05 jan. 2014.

${ }^{39}$ SCHWAB, Jean-Luc; BRAZDA, Rudolf. Triângulo rosa. Um homossexual no campo de concentração nazista. São Paulo: Mescla, 2011, p. 29- 32.

${ }^{40}$ SCHWAB, Jean-Luc; BRAZDA Rudolf. Triângulo rosa. Um homossexual no campo de concentração nazista. São Paulo: Mescla, 2011, p. 111- 128.
} 
tentaram prender homossexuais e travestis que estavam no bar "Stonewall Inn", por estarem consumindo bebidas alcóolicas, que eram proibidas para os homossexuais. Assim, os policiais tentaram prender uma série de homossexuais e travestis pelo simples fatos de não serem heterossexuais. Tais conflitos se estenderam por dias e ficaram conhecidos como os tumultos de Stonewall, tendo sido eles que inspiraram a criação da Parada do Orgulho Gay. ${ }^{41}$

A partir de então, ganhou força o movimento homossexual norte-americano, por meio da criação de inúmeras associações em todo o país, promotores de protestos, demonstrações, desfiles públicos e publicações. Neste contexto, foi cunhada a expressão "gay", para designar uma atitude de auto-estima e ativismo diante do preconceito e da discriminação, os quais eram objetos de combate destes grupos. ${ }^{42}$

No século XX, e nos dias atuais, começa a haver uma maior tolerância com a diversidade sexual, devido às normas de proteção dos direitos humanos, o que permitiu, no mundo pós-moderno, o surgimento de um conceito plural de família.

\subsection{Conclusão}

Na Grécia, a permissão para a homossexualidade era bem diferente da que existia em Roma.

Para os gregos, a homossexualidade estava ligada à cultura, ao belo, à guerra, às habilidades políticas e militares. Enfim, um relacionamento entre pessoas livres. Tinha ligação com deuses, mitos e heróis. No mesmo sentido era vista a homossexualidade feminina. O relacionamento entre um homem mais velho e um adolescente era permitido e incentivado. A bissexualidade estava presente.

Por outro lado, a homossexualidade em Roma era aceita apenas entre homens livres e escravos, existindo uma correlação entre a conquista militar e a dominação sexual.

\footnotetext{
41 VECCHIATTI, Paulo Roberto Iotti. Manual da Homoafetividade. Da possiblidade jurídica do casamento civil, da união estável e da adoção por casais homoafetivos. 2. ed. São Paulo: Gen, Método, 2012 , p. 33.

${ }^{42}$ RIOS, Roger Raupp. O princípio da Igualdade e a Discriminação por Orientação Sexual. A Homossexualidade no Direito Brasileiro e Norte-Americano. São Paulo: Revista dos Tribunais, 2002, p. 118.
} 
A bissexualidade estava presente, mas a passividade era rechaçada, pois a sexualidade masculina romana estava fundamentada no princípio da subjugação. A sexualidade passiva era tida como uma conduta feminina e o homem que assim agisse era visto como sendo equiparado às mulheres, ou seja, um cidadão de segunda classe.

Ao contrário da Grécia, o relacionamento homossexual de um homem mais velho com um adolescente era proibido pela lei Scantinia no início da República Romana não havendo restrição se fosse o ato praticado com um escravo.

Porém, com a conquista da Grécia Antiga pelo Império Romano e a adoção da cultura helênica, passou o Império Romano a ter suavizada a ideia de virilidade baseada na dominação. A visão do sexualmente passivo provou-se relativa no Império Romano, quando o homem em questão tinha outras atitudes vistas como eminentemente masculinas. Um exemplo clássico foi o notório Imperador Júlio César.

Os costumes gregos foram sendo gradualmente aceitos pela sociedade romana nos anos finais da República e no início do Império. A prática da pederastia teve o seu apogeu durante o reinado do Imperador Adriano. É famoso seu amor pelo jovem grego Antínoo.

Segundo o historiador John Boswell existem evidências de que os romanos do período republicano atribuíram às uniões homossexuais o mesmo "status" dado às uniões heterossexuais. Dá como exemplo o casamento do imperador Elegabalus com um atleta e o casamento de Nero com Sporus.

Esta é uma visão histórica do casamento homossexual em Roma, não é jurídica afirmaram meu orientador, Professor Álvaro Villaça Azevedo, e o Professor Rui Geraldo Camargo Viana no exame de qualificação.

Pesquisando a visão jurídica, encontramos, na Universidade de Camerino (Itália), o livro "Ubi Venus Mutatur, Omosessualità e Diritto Nel Mondo Romano", de autoria de Danilo Dalla. O autor argumenta que o escasso interesse jurídico se funda na aversão pelo tema sendo, até hoje, limitadas as pesquisas sobre o assunto. A lacuna e a atualidade do tema solicitam a pesquisa jurídica, sem preconceitos ou condicionamentos.

Por meio de uma pesquisa robusta, o autor Danilo Dalla refere-se a aspectos jurídicos do homoerotismo permitido entre patrão e servo. Sendo que o termo servo podese referir tanto ao escravo quanto à escrava. Após, houve uma limitação da prática com 
uma norma de Vespasiano com relação aos escravos de ambos os sexos que deveriam ser vendidos com o pacto de não serem prostituídos. Caso o patrão desrespeitasse o pacto o escravo seria liberto.

Com relação ao matrimônio homossexual, Dalmo Dalla, referindo-se à afirmação do historiador John Boswell, citada acima, afirma tratar-se exclusivamente de fonte histórica sem qualquer embasamento em fontes jurídicas. Referindo-se à união de Nero e Sporus, não entende ser de interesse jurídico, pois aparenta ser um envolvimento entre um homem livre e um escravo. Concluindo, deixa claro que tais episódios podem ser relevantes para os costumes, mas não deixaram traços no direito como sendo matrimônio. $\mathrm{Na}$ verdade, os romanos tiveram sempre a convicção de que o matrimônio deveria ter como pressuposto a existência de pessoas de sexos diversos.

A partir do Imperador Justiniano, Roma assume expressamente posicionamento contrário às práticas homossexuais e será esta a orientação a ser seguida durante as Idades Média e Moderna.

O pensamento estoico desvalorizava a bissexualidade e concentrava a sexualidade no casamento e na procriação. Esse movimento filosófico criou as bases para a adoção do cristianismo como religião predominante no Império Romano, instituindo a condenação moral da homossexualidade.

Com o advento do cristianismo, a influência greco-romana se dissipou e o mito Sodoma e Gomorra ganhou espaço transformando a homossexualidade em pecado.

A sacralização da união heterossexual aconteceu na Idade Média e o casamento foi transformado em sacramento. O ato sexual só era permitido dentro do casamento e para procriação, caso contrário seria pecado.

Este novo pensamento social consolidado na Idade Média fez com que os relacionamentos homossexuais acontecessem às escondidas.

$\mathrm{Na}$ Idade Moderna a vida era levada fazendo-se vistas grossas a esses relacionamentos como se fossem invisíveis, fazendo de conta que não existiam.

A partir dos séculos XIX e XX a sociedade passou a ser menos intolerante em relação à homossexualidade, mas não se impediu que milhares de homossexuais fossem 
assassinados nos campos de concentração nazistas sendo, também, vítimas de tratamentos experimentais de inversão da preferência sexual.

Nos dias atuais, começa a haver uma maior tolerância com a diversidade sexual, tendo em vista as normas de proteção dos direitos humanos. Porém o preconceito e a violência contra os homossexuais ainda faz parte da sociedade. 


\section{PRÉ-CONCEITOS SOBRE A HOMOSSEXUALIDADE}

De acordo com Spencer Colin, a passagem do conceito de homossexualidade como pecado para homossexualidade como crime, e, depois, homossexualidade como doença, isto é, insanidade, foi provocada pelas intensas mudanças sociais que ocorreram na história. $^{43}$

Por meio das três concepções citadas acima é possível traçar um quadro a respeito das diversas visões sobre a homossexualidade, que se perpetuam até os dias de hoje, quer por crença religiosa, quer por previsão legislativa, quer por preconceito e desinformação. Tais concepções trazem em seu bojo uma carga enorme de intolerância.

Assim, a homossexualidade teve ciclos ao longo da história da humanidade, experimentando diversos altos e baixos. De comportamento absolutamente natural, passou a ser pecado e até mesmo crime. É, até nos dias de hoje, um assunto que provoca fortes debates.

\subsection{Homossexualidade como pecado}

De acordo com essa concepção, a prática de atos sexuais entre pessoas do mesmo sexo é entendida como moralmente reprovável e, no plano religioso, pecaminosa. Assim, toda prática sexual não reprodutiva é qualificada negativamente, levando a transgressão do plano divino e afastamento da vida espiritual. No universo judaico-cristão, a primeira fonte de condenação à homossexualidade é a Bíblia, cuja invocação de algumas passagens tem sido interpretada como condenatória destas práticas. ${ }^{44}$

Os trechos bíblicos normalmente citados como condenatórios da homossexualidade são os que se referem a Sodoma e Gomorra, à abominação do Levítico, à Epístola de Paulo aos Romanos e os referentes a 1 Coríntios e 1 Timóteo. No entanto,

\footnotetext{
${ }^{43}$ SPENCER, Colin. Homossexualidade: uma história. Rio de Janeiro: Record, 1995, p. 235-259.

${ }^{44}$ RIOS, Roger Raupp. O princípio da Igualdade e a Discriminação por Orientação Sexual. A Homossexualidade no Direito Brasileiro e Norte-Americano. São Paulo: Revista dos Tribunais, 2002, p. 100102.
} 
esses trechos condenam outras condutas, nas quais, por acaso, a homossexualidade está envolvida. ${ }^{45}$

O padre Helminiak (Ph.D em teologia e Ph.D em psicologia educacional), em seu livro "O que a Bíblia realmente diz sobre a homossexualidade" afirma que aqueles que optam por fazer uma leitura "ao pé da letra" da Bíblia precisam compreender como os outros podem, em boa-fé, insistir na afirmação de que a Bíblia não condena a homossexualidade. Muitos homossexuais foram educados para acreditar na Bíblia, e aprenderam que ela condena a homossexualidade. Portanto, parece que os homossexuais devem optar entre desistir de sua religião ou, o que parece impossível, desistir de sua sexualidade. Seu trabalho apoia-se principalmente naquele de John Boswell, professor de História da Universidade de Yale, que desenvolveu um meticuloso estudo dos termos bíblicos. Em breves palavras, o pecado de Sodoma foi o da falta de hospitalidade, e não o da homossexualidade. $\mathrm{O}$ que se condenou foi o sexo com os anjos, mas não o sexo entre dois homens. ${ }^{46}$

Além disso, cumpre ressaltar que o termo "sodomia" tem um sentido diverso daquele utilizado há séculos para se referir pejorativamente ao ato homossexual. Inicialmente sodomia significava todo e qualquer ato sexual não procriativo. Assim, como

\footnotetext{
${ }^{45}$ VECCHIATTI, Paulo Roberto Iotti. Manual da Homoafetividade. Da possiblidade jurídica do casamento civil, da união estável e da adoção por casais homoafetivos. 2. ed. São Paulo: Gen., Método, 2012, p. 59.

${ }^{46}$ HELMINIAK, Daniel A.. O que a Bíblia realmente diz sobre a homossexualidade. Tradução Eduardo Teixeira Nunes. São Paulo: Edições GLS, 1998, p. 15 a19, 123. A história de Sodoma está no livro do Gênesis, capítulo 19, versículos de 1 a 11: Pela tarde chegaram os dois anjos a Sodoma, Lot, que estava assentado à porta da cidade, ao vê-los levantou-se e foi-lhes ao encontro e prostou-se com o rosto por terra. "Meus senhores, disse-lhes ele, vinde, peço-vos, para a casa de vosso servo e passai nela a noite; lavareis os pés e amanhã cedo continuareis vosso caminho." - "Não, responderam eles, passaremos a noite na praça". Mas Lot insistiu tanto com eles que acederam e entraram em sua casa. Lot preparou-lhes um banquete, mandou coser pães sem fermento, e eles comeram. Mas antes que se tivessem deitado, eis que os homens da cidade, os homens de Sodoma, se agruparam em torno da casa, desde os jovens até os velhos, toda a população. E chamaram a Lot: "Onde estão, disseram-lhe, os homens que entraram esta noite em tua casa? Conduze-os a nós para que os conheçamos." Saiu Lot a ter com eles no limiar da casa, fechou a porta atrás de si, e disse-lhes: "Suplico-vos, meus irmãos, não cometais este crime. Ouvi: tenho duas filhas que são virgens, eu vo-las trarei, e fazeis delas o que quiserdes. Mas não façais nada a estes homens, porque se acolheram à sombra do meu teto. "Eles responderam: "Retira-te, daí! - e acrescentaram: Eis um indivíduo que não passa de um estrangeiro no meio de nós (Lot não havia nascido em Sodoma) e se arvora em juiz! Pois bem: verás como te havemos de tratar pior do que a eles." E, empurrando Lot com violência, avançaram para quebrar a porta. Mas os dois viajantes estenderam a mão, e tomando Lot para dentro de casa, fecharam de novo a porta. E feriram de cegueira os homens que estavam fora, jovens e velhos, que se esforçavam em vão por reencontrar a porta.
} 
o ato homossexual se enquadra na ideia de "ato sexual não procriativo", podia este ser enquadrado no conceito de "sodomia". 47

No Antigo Testamento, em trecho do Livro do Levítico 18:22, em relação à homossexualidade, a Bíblia traz o seguinte posicionamento: "Não te deitarás com um homem, como se fosse mulher: isso é uma abominação". Mas adiante, completando esta referência, o Levítico 20:13 acrescenta a punição: "Se um homem dormir com outro homem, como se fosse mulher, ambos cometeram uma coisa abominável. Serão punidos de morte e levarão a sua culpa." Não há dúvida de que o texto refere-se a atos homossexuais masculinos. Não há qualquer menção a atos sexuais entre lésbicas neste texto. A ofensa é chamada abominação, e a pena indicada é a de morte. Outros pecados sexuais também merecem a pena de morte: adultério, incesto e bestialidade. A lei do Levítico considerava todos estes crimes como muito sérios, mas por motivos diferentes. Portanto, o simples fato de saber que um determinado crime implicava a pena de morte não significa muita coisa. A questão importante é: qual era o real significado da ofensa que causou a punição e por que esta ofensa era considerada tão seriamente? Como veremos o problema não era o sexo em si. Entre os antigos israelitas, assim como o Levítico o interpreta, praticar atos homossexuais significava ser como os gentios, era o equivalente a identificar-se com os não-judeus. Isto quer dizer que a prática de atos homossexuais representava uma traição à religião judaica. O Levítico condenava o sexo homossexual como um crime religioso de idolatria e não como uma ofensa sexual, e era esta traição religiosa o que era considerado grave o suficiente para merecer a pena de morte. ${ }^{48}$

Com relação à Epístola de Paulo aos Romanos, este é o famoso texto de onde as pessoas tiram a conclusão de que o sexo homossexual não é "natural”. Este também pode ser o único texto da Bíblia que mencione o sexo entre lésbicas. Mas se considerarmos para quem Paulo estava escrevendo, como ele desenvolveu sua argumentação e com que finalidade, todas estas conclusões parecerão estar erradas. A Epístola de Paulo aos Romanos levanta a questão acerca do que é "natural" e do que não é. Nela ele diz que os homens "deixando o uso natural da mulher, arderam em desejos uns para com os outros". $\mathrm{E}$ as mulheres "mudaram as relações naturais em relações contra a natureza". O que

\footnotetext{
${ }^{47}$ VECCHIATTI, Paulo Roberto Iotti. Manual da Homoafetividade. Da possiblidade jurídica do casamento civil, da união estável e da adoção por casais homoafetivos. 2. ed. São Paulo: Gen. , Método, 2012, p. 60.

${ }^{48}$ HELMINIAK, Daniel A.. O que a Bíblia realmente diz sobre a homossexualidade. Tradução Eduardo Teixeira Nunes. São Paulo: Edições GLS, 1998, p. 47-49.
} 
realmente Paulo pretendia dizer quando utilizou as palavras "contra a natureza"? Não é fácil responder a esta pergunta, mas temos bem claro que Paulo não usou a palavra "natureza" com o mesmo sentido abstrato e genérico que empregamos ao citar "a Natureza e as leis da Natureza". Assim, para Paulo a "natureza" de alguma coisa era sua característica ou tipo particular, refere-se àquilo que é característico, consistente, comum, padrão, regular e esperado. Portanto o significado na Epístola aos Romanos é que estas mulheres e homens estavam envolvidos em práticas sexuais que não eram aquelas normalmente adotadas pelas pessoas. Portanto não há nessas palavras qualquer acepção indicando que as práticas estavam erradas ou eram contrárias a Deus ou iam de encontro à ordem divina da criação, nem que estavam em conflito com a natureza universal das coisas. Finalmente, por meio do obscuro termo grego "arsenokoitai", 1 Coríntios e 1 Timóteo condenam os abusos associados à atividade homossexual no século I, ou seja, a exploração e libertinagem, mas não os atos homossexuais em geral. Assim conclui-se que se os homossexuais se utilizarem da Bíblia para encontrar orientação e inspiração seguramente serão guiados pelos ensinamentos morais da tradição judaico-cristã a: ser uma pessoa de fé, reverenciar a Deus, respeitar os outros, ser gentil, ter compaixão e saber perdoar, ser honesto e justo. Trabalhar pela harmonia e pela paz, erguer a voz em defesa da verdade e evitar tudo aquilo que se sabe ser ruim. Fazer isso é amar a Deus de todo o coração e alma. Fazer isso é ser um verdadeiro discípulo de Jesus. Portanto isto é tudo o que pode ser dito honestamente acerca dos ensinamentos bíblicos sobre a homossexualidade, pois a Bíblia parece deliberadamente não estar preocupada com este assunto. $^{49}$

Assim, nos primórdios, a homossexualidade era reprovada pela Igreja, e tida como grave infração a qual originou a ira divina destruidora de Sodoma e Gomorra, e mais tarde como pecado em que a Inquisição castigou com a morte. A Igreja repudia a busca do homem somente pelo prazer em suas relações sexuais, como se concebe quando se unem duas pessoas do mesmo sexo, tendo em vista que a natureza biológica não permite a procriação a partir dessas relações. ${ }^{50}$

\footnotetext{
${ }^{49}$ HELMINIAK, Daniel A.. O que a Bíblia realmente diz sobre a homossexualidade. Tradução Eduardo Teixeira Nunes. São Paulo: Edições GLS, 1998, p. 67-71, 95, 124.

${ }^{50}$ CHAVES, Marianna. Homoafetividade e Direito. Proteção Constitucional, Uniões, Casamento e Parentalidade. $2^{\mathrm{a}}$ edição. Curitiba: Juruá, p. 59-60.
} 
Não se pode negar que o conteúdo bíblico, atravessando milênios, influenciou e influencia a maior parte dos países e, quando uma religião é nitidamente majoritária é nela que, em geral, se inspiram as decisões do legislador. ${ }^{51}$

No Brasil, não foi diferente, como pode ser verificado nas Ordenações Filipinas, vigentes até 1830 em nosso país, que impingiam aos atos homossexuais a pecha de gravidade extrema, atribuindo ao pecado da sodomia um fato típico e antijurídico, fundindo-se Estado e Igreja, como pode ser visto em seu texto:

Toda pessoa, de qualquer qualidade que seja, que pecado de sodomia por qualquer maneira cometer, seja queimado e feito por fogo em pó, para que nunca de seu corpo e sepultura possa haver memória, e todos seus bens sejam confiscados para a coroa de nossos Reinos, posto que tenha descendentes; e pelo mesmo caso seus filhos e netos ficarão inabilitados e infames, assim como os daqueles que comete o crime de LesaMajestade.

1. E esta lei, queremos que também se estenda e haja lugar nas mulheres, que umas com as outras cometem pecado contra a natureza e da maneira que temos dito nos homens.

2. Outrossim, qualquer homem ou mulher, que carnalmente tiver ajuntamento com alguma alimária, seja queimado e feito em pó. Porém por tal condenação não ficarão seus filhos, nem descendentes neste caso inabilitados, nem infames, nem lhes fará prejuízo algum acerca da sucessão, nem a outros, que por Direito seus bens devam herdar. ${ }^{52}$

Em agosto de 2003, o Vaticano, em uma das suas manifestações, ainda no tempo do Papa João Paulo II, apresentou uma campanha mundial contra a legalização de uniões homossexuais e solicitou aos políticos católicos de todo mundo que se manifestassem contrariamente às leis que as facilitassem. A Igreja afirmava que reconhecer legalmente as uniões homoafetivas ou equipará-las ao matrimônio significava aprovar um comportamento desviado, assim como afetar valores fundamentais. ${ }^{53}$

Hodiernamente, a Igreja Católica, na pessoa do Papa Francisco em 29 de julho de 2013, surpreendeu a todos, em entrevista aos jornalistas, quando se referiu aos relacionamentos homossexuais, dizendo:

Quem sou eu para julgar os gays? Se uma pessoa é gay e procura Deus e tem boa vontade, quem sou eu para julgá-la? O catecismo da Igreja

\footnotetext{
${ }^{51}$ BRANDÃO, Debora Vanessa Caús. Parcerias Homossexuais. Aspectos Jurídicos. São Paulo: RT, 2002, p. 29.

52 RIOS, Roger Raupp. O Princípio da Igualdade e a Discriminação por Orientação Sexual. A Homossexualidade no Direito Brasileiro e Norte-Americano. São Paulo: RT, 2002, p. 104-105.

53 CHAVES, Marianna. Homoafetividade e Direito. Proteção Constitucional, Uniões, Casamento e Parentalidade. 2. ed.. Curitiba: Juruá, p. 62.
} 
explica que eles não devem ser marginalizados por causa disso, mas devem ser integrados na sociedade.

Porém deixou claro que não haverá uma nova opinião do Vaticano sobre o casamento homossexual ${ }^{54}$.

Toda religião tem seus dogmas que devem ser respeitados, o que evidencia coerência na afirmação do Vaticano sobre a não aceitação do casamento religioso homossexual. Porém, a postura de tolerância do atual Papa Francisco, com relação aos homossexuais e suas famílias, é muito importante, pois faz diminuir as manifestações de ódio e de preconceito.

Assim, o Papa Francisco tem mostrado atitude de respeito e de acolhimento pela forma como a família vem se modificando. Dialogar pressupõe humildade para entender um momento que soa renovador.

No Brasil de hoje, apesar de vivermos num Estado laico, podemos observar que alguns membros do Poder Legislativo tem uma forte tendência de legislar sob a influência do conceito de homossexualidade como pecado. Em 27 de maio de 2014, a Comissão de Constituição e Justiça e Cidadania manifestou parecer do Relator, Deputado Eduardo Cunha (PMDB-RJ) pela constitucionalidade, juridicidade e técnica legislativa e, no mérito, pela aprovação do projeto de lei PL 1.411/2011, de autoria do deputado Washington Reis (PMDB-RJ) que:

\section{Ementa \\ Acrescenta parágrafo ao art. 20 da Lei no 7.716, de 5 de janeiro de 1989. \\ Explicação da Ementa \\ Descaracteriza crime a recusa, em templos religiosos, de aceitar ou efetuar cerimônias ou pessoas em desacordo com suas crenças e liturgias.}

Este projeto acrescenta parágrafo $5^{\circ}$ ao artigo $20^{55}$ da Lei $7.716 / 1989$, que define os crimes resultantes de preconceito de raça ou de cor, pois esta lei tem sido usada por homossexuais que se sentem discriminados.

Art. $1^{\circ} \mathrm{O}$ art. 20 da Lei 7.716/1989, que define os crimes resultantes de preconceito de raça ou de cor, passa a vigorar acrescido do seguindo $\S 5^{\circ}$ :

\footnotetext{
${ }^{54}$ CHADE, Jamil. Entrevista com o Papa Francisco: “Quem sou eu para julgar os gays". Disponível em http://internacional.estadao.com.br/blogs/jamil-chade/entrevista-com-o-papa-francisco-quem-so Acesso em 29 jul. 2013.

55 Art. 20, Lei 7.716/1989: "Praticar, induzir ou incitar a descriminação ou preconceito de raça, cor, etnia, religião ou procedência nacional. Pena: reclusão de um a três anos e multa."
} 
$\S 5^{\circ} \mathrm{O}$ caput deste artigo não se aplica:

I- à manifestação do pensamento decorrente de ato de fé, que em razão da liberdade religiosa não obriga qualquer organização religiosa a efetuar casamento religioso em desacordo com suas crenças;

II- à prática do exercício de culto religioso, sendo livre e opcional, não configurando discriminação a recusa de organizações religiosas na permanência de cidadãos que violem seus valores, doutrinas, crenças e liturgias. ${ }^{56}$

Na prática, a proposta quer evitar que os religiosos sejam criminalizados, caso se recusem a realizar casamentos homossexuais, ou mesmo aceitar a presença dessas pessoas em templos religiosos.

Com relação ao inciso I, a não obrigatoriedade de efetuar casamento religioso em desacordo com suas crenças, é razoável e aceitável em respeito aos dogmas de cada religião, porém o inciso II fere o princípio da igualdade e da dignidade da pessoa humana, pois uma lei não pode autorizar a expulsão de homossexuais de templos religiosos.

Com relação à Lei 7.716/1989, que era usada pelos homossexuais para se defenderem de atos homofóbicos, o Supremo Tribunal Federal deixou claro que não é possível a utilização desta lei para este fim. Em denúncia apresentada pelo Ministério Público Federal, o deputado federal Marco Feliciano foi acusado da prática do crime previsto no artigo 20, da Lei 7.716/1989, que define os crimes resultantes de preconceito de raça ou de cor, por ter publicado em 2011 que "a podridão dos sentimentos dos homoafetivos leva ao ódio, ao crime, à rejeição". O entendimento da $1^{\mathrm{a}}$ Turma do Supremo Tribunal Federal, por unanimidade, rejeitou a denúncia. O ministro relator Marco Aurélio lembrou que o artigo 20 trata de discriminação e preconceito, considerada a raça, a cor, a etnia, a religião ou a procedência nacional, "não contemplando a discriminação decorrente da opção sexual". O relator observou que o inciso XXXIX, do artigo $5^{\circ}$, da Constituição Federal, é claro no sentido de que não há crime sem lei anterior que o defina, nem pena sem prévia cominação legal. ${ }^{57}$

Embora correta a interpretação do Ministro Relator, melhor seria se o termo “opção sexual”, fosse substituído pelo termo “orientação sexual”.

\footnotetext{
56 PL 1.411/2011. Acrescenta parágrafo ao artigo 20 da Lei 7.716, de 5 de janeiro de 1989. Disponível em http://www.camara.gov.br/proposicoesWeb/fichadetramitacao?idProposicao=503350. Acesso em 17 abr. 2015.

57 Supremo rejeita denúncia contra Feliciano por crime de homofobia. Disponível em http://www.conjur.com.br/2014-ago-12/stf-rejeita-denuncia-feliciano-homofobia... Acesso em 13 ago. 2014.
} 
Pelo motivo de o Poder Legislativo não aprovar a criminalização da homofobia a incitação ao ódio e ao crime contra os homossexuais fica impune.

Com relação ao PLC 122/06, que criminaliza a homofobia, em 17 de dezembro de 2013 o Senado Federal acolheu requerimento formulado por opositores do PLC/122 para que o referido projeto seja apensado ao "Projeto de Código Penal" (PL 236/2012). Sendo assim, a proteção contra a discriminação por orientação sexual, em nível federal, e no âmbito penal, terá de esperar os muitos anos que um projeto de código normalmente leva para ser votado.

Com relação á proteção dos homossexuais em nível estadual, podemos citar a Lei Estadual de São Paulo, n 10.948/2001, que dispõe sobre as penalidades a serem aplicadas à prática de discriminação em razão de orientação sexual. Convênio firmado pela $\mathrm{OAB} / \mathrm{SP}$ e o Governo do Estado prevê a capacitação de advogados aos termos desta lei, que pune no âmbito administrativo, toda manifestação atentatória ou discriminatória praticada contra cidadão ou cidadã homossexual, bissexual ou transgênero. ${ }^{58}$

Entre nós, a adoção pelo Estado do conceito da homossexualidade como pecado seria francamente incompatível com os princípios da liberdade de religião e da laicidade, de acordo com os artigos $5^{\circ}$, inciso VI e artigo 19, inciso I, ambos da Constituição Federal. $^{59}$

\footnotetext{
${ }^{58}$ Seguindo o exemplo de outros estados, em 05.11.2001, o estado de São Paulo fez publicar a Lei 10.948, que dispõe sobre as penalidades a serem aplicadas em virtude da prática de discriminação em razão de orientação sexual. A lei paulista visou proteger todas as pessoas, que se orientam sexualmente de maneira diversa à heterossexualidade, das usuais agressões físicas ou psíquicas. Para viabilizar a referida tutela, o art. $2^{\circ}$ traz oito incisos elencando condutas consideradas atentatórias e discriminatórias dos direitos individuais e coletivos daqueles indivíduos. Nele foram incluídas as situações constrangedoras mais frequentes pelas quais passam os homossexuais bissexuais ou transgêneros. As sanções aos que infringirem a Lei 10.948/2001 vão desde advertência até cassação da licença estadual para funcionamento. O órgão competente para apurar as denúncias e impor as penalidades administrativamente é Secretaria da Justiça e da Defesa da Cidadania.

${ }^{59}$ Art. 5', VI, CF: “é inviolável a liberdade de consciência e de crença, sendo assegurado o livre exercício dos cultos religiosos e garantida, na forma da lei, a proteção aos locais de culto e as suas liturgias. Art. 19, I, CF. É vedado à União, aos Estados, ao Distrito federal e aos Municípios: I- estabelecer cultos religiosos ou igrejas, subvenciona-los, embaraçar-lhes o funcionamento ou manter com eles ou seus representantes relações de dependência ou aliança, ressalvada, na forma da lei, a colaboração de interesse público";
} 


\subsection{Homossexualidade como crime}

A criminalização da homossexualidade é a forma de homofobia promovida pelo próprio Estado.

Conforme o relatório de maio de 2013, da Associação Internacional de Lésbicas, Gays, Bissexuais, Travestis e Intersexuais (ILGA), a homossexualidade é considerada crime previsto em leis de 76 países, sendo punida com penas de prisão de até 10 anos e, por vezes, há previsão de prisão perpétua. A pena de morte para os atos homossexuais é prevista em 5 desses países e em algumas partes da Nigéria e da Somália. Estes cinco países são: Arábia Saudita, Irã, Iémen, Mauritânia e Sudão. ${ }^{60}$

A rainha da Inglaterra Elizabeth $2^{\mathrm{a}}$, em 24 de dezembro de 2013, anunciou uma medida de peso simbólica, perdoando o matemático e criptoanalista Alan Turing (19121954), sessenta e um anos após ter sido condenado por "indecência" na década de 1950. Devido a seu relacionamento com outro homem, em 1952, ele foi condenado por "grave indecência”, tal como o escritor Oscar Wilde em 1895.

O matemático foi submetido à vigilância ostensiva e forçado a um tratamento hormonal com estrogênio a fim de reprimir seus impulsos sexuais. Alan Turing morreu em 7 de junho de 1954, dias antes de completar 42 anos de idade. Uma corte definiu suicídio como causa oficial. No entanto, esse veredito tem sido questionado.

O cientista nascido em Londres está entre os heróis da Segunda Guerra Mundial por ter decifrado o Código Enigma, utilizado pelos nazistas em suas comunicações. Em declaração publicada em 24 de dezembro de 2013, o ministro britânico da Justiça, Chris Grayling, informou que o decreto real tem efeito imediato. Acrescentou que o perdão é um tributo a um homem excepcional, com uma mente brilhante.

Normalmente esse tipo de indulto só é concedido no Reino Unido quando a pessoa é inocente de um crime que constava dos estatutos na época da condenação; e quando o requerimento é feito por alguém com interesse direto, tal como um membro da

60 ITABORAY, Lucas Paoli; ZHU Jingshu. Homofobia do Estado. Análise mundial das leis: criminalização, proteção e reconhecimento do amor entre pessoas do mesmo sexo. 8. ed., mai. 2013.Disponível em: http://old.ilga.org/Statehomophobia/ILGA_State_Sponsored_Homophobia_2013_portuguese.pdf. Acesso em 22 dez. 2013. 
família. No caso de Turing, o perdão foi concedido sem que nenhuma dessas condições tenha sido preenchida.

Segundo o primeiro-ministro David Cameron, a decodificação das mensagens trocadas entre os nazistas teria salvado incontáveis vidas. As informações obtidas foram essenciais para combater a ofensiva alemã no Norte da África, ou em ajudar os navios aliados a escapar de submarinos nazistas no Oceano Atlântico. Ele também deixou um legado nacional incontável, por meio de suas substanciais conquistas científicas, sendo frequentes as referências a ele como pai da moderna computação.

O gesto simbólico de Londres é importante no momento de recrudescimento da intolerância sexual no mundo, quando a Rússia e a Índia, por exemplo, endurecem suas legislações homofóbicas. ${ }^{61}$

Como disse o líder indiano Gandhi, uma civilização é julgada pelo tratamento que dispensa às minorias. A criminalização é a pior forma de homofobia que existe. Porém, a Suprema Corte da Índia mantém como crime o sexo entre pessoas do mesmo sexo e decidiu em 11 de dezembro de 2013 que o sexo consensual entre dois adultos continua a ser um crime no país, em um grande golpe para os direitos dos homossexuais na maior democracia do mundo. Em 2009, o Tribunal de Nova Délhi deliberou que o sexo consensual entre adultos não seria uma ofensa, derrubando uma lei da era colonial do século XIX. Esta decisão tinha sido contestada por ativistas contrários aos homossexuais e organizações sociais e religiosas. De acordo com a Suprema Corte, este é um assunto para ser discutido pelos congressistas e não por tribunais. A seção 377 do Código Penal da Índia proíbe "sexo contra a ordem da natureza com qualquer homem, mulher ou animal", o que é amplamente interpretado no sentido do sexo homossexual. A decisão chocou os ativistas dos direitos dos homossexuais, que prometeram continuar a lutar pela remoção da lei que pune o sexo homossexual com até dez anos de prisão. ${ }^{62}$

Em Uganda, o parlamento em 20 de dezembro de 2013, aprovou um projeto de lei que reprime a homossexualidade de modo rigoroso, no qual inclui a prisão perpétua para os reincidentes. A homossexualidade já era proibida em Uganda, mas esta nova lei

\footnotetext{
${ }^{61}$ Perdão a Cientista Homossexual Alan Turing vem com Seis Décadas de Atraso. Disponível em: http://www.dw.de/perd\%/C3\%A3o-a-cientista-homossexual-alan-turing-vem-com-seis-d\%C3\%A9c.... Acesso em 26 dez. 2013.

62 Suprema Corte da Índia mantém sexo entre gays como crime. Disponível em: http://oglobo.com/mundo/suprema-corte-da-india-mantem-sexo-entre-gays-com... Acesso em 11 dez. 2013.
} 
endurece as penas e criminaliza a defesa pública das relações entre pessoas do mesmo sexo, inclusive os debates dos grupos de ativistas. Em princípio, o projeto previa a pena de morte para quem fosse flagrado pela segunda vez realizando um ato homossexual, assim como para as relações em que um dos participantes fosse menor de idade ou portador do vírus da Aids. Porém, na versão final do projeto, foi suprimida uma controversa cláusula sobre a pena de morte. ${ }^{63}$

A nova lei, aprovada pelo presidente Yoweri Museveni em 24/02/2014, legitimou abusos e repressão. Pessoas identificadas como lésbicas, gays, bissexuais, transgênero e intergênero (LGBTI) eram presas arbitrariamente, mesmo quando elas mesmas procuravam a polícia para reportar crimes contra elas.

Felizmente essa lei foi derrubada pela Corte Constitucional de Uganda em agosto de 2014, com base no fato de ter sido aprovada sem quórum pelo Parlamento. ${ }^{64}$

Dos 54 países do continente africano, 37 criminalizam a homossexualidade.

No Brasil, ainda temos alguns resquícios sobre a criminalização das práticas homossexuais no Código Penal Militar (CPM), artigo 235, que tipifica como crime a "pederastia ou outro ato de libidinagem" e prevê pena de detenção, de 6 meses a 1 ano ao militar que praticar, ou permitir que com ele se pratique ato libidinoso, homossexual ou não, em lugar sujeito a administração militar.

A Procuradoria Geral da República (PGR) ajuizou, no Supremo Tribunal Federal (STF), em 19/09/2013, Arguição de Descumprimento de Preceito Fundamental (ADPF) 291 na qual questiona a constitucionalidade do artigo 235 do Código Penal Militar (CPM), pois o dispositivo viola os princípios da isonomia, da liberdade, da dignidade da pessoa humana, da pluralidade e do direito à privacidade. E mais: a norma do artigo 235 do Código Penal Militar foi criada no contexto histórico de um regime militar ditatorial; os termos "pederastia" e "homossexual ou não" teriam "viés totalizante e antiplural".

\footnotetext{
63 Uganda aprova lei rigorosa para reprimir homossexualidade. Disponível em: http://g1.globo.com/mundo/noticia/2013/12/uganda-aprova-lei-rigorosa-para-reprimir... Acesso em $21 \mathrm{dez}$ 2013; Folha de São Paulo, mundo, A19, 21/12/2013. Uganda punirá gays com prisão perpétua.

64 Uganda. Legislação Discriminatória Alimentam Abusos e Repressão. Disponível em: http://anistia.org.br/noticias/uganda-legislação-discriminatoria-alimentam-abusos-e-repressao/ Acesso em 22 out. 2014.
} 
Para corroborar a argumentação, a Procuradoria lembra a exposição de motivos do Código Penal Militar para incluir entre os crimes sexuais a nova figura da pederastia: "É a maneira de tornar mais severa a repressão contra o mal, onde os regulamentos disciplinares se revelarem insuficientes", diz o texto. A PGR sustenta que a discriminação é explícita, e, mesmo com a retirada dos termos pederastia e homossexual sua aplicação continuará afetando intencionalmente os homossexuais, tendo em vista que a grande maioria do contingente das Forças Armadas é masculina, e havendo ambientes estritamente masculinos, os heterossexuais, em tese, não seriam atingidos pela norma de austeridade sexual.

A Procuradoria aponta que a norma tem o objetivo de limitar a liberdade sexual dos militares e ressalta que, em qualquer ambiente de trabalho, os atos inapropriados são punidos. No caso, porém, o Código Penal Militar utiliza o direito penal, cujo princípio é o da intervenção mínima, para reprimir o que é considerado inapropriado em algumas situações.

Ao final, a PGR pede a concessão de medida cautelar para suspender a eficácia do artigo 235 do Código Penal Militar, até o julgamento definitivo da arguição. No mérito, pede que seja declarada a não recepção do dispositivo pela Constituição de 1988. O relator da ADPF é o ministro Luís Roberto Barroso. ${ }^{65}$

Em agosto de 2005, a Comissão de Constituição e Justiça e Cidadania da Câmara dos Deputados aprovou o Projeto de Lei 2773/2000, do deputado Alceste Almeida (PMDB-RR), que exclui a referência à pederastia no Código Penal Militar, em função de uma possível inconstitucionalidade do artigo, que discriminaria os homossexuais. $\mathrm{O}$ projeto mantém como crime militar quaisquer práticas sexuais no ambiente militar, sem qualquer referência à homossexualidade. O projeto está sendo analisado em conjunto com outro, o Projeto de Lei 6871/2006, da deputada Laura Carneiro (PFL-RJ), que também exclui a referência à pederastia e à discriminação homossexual no texto da lei, porém permite o ato sexual no ambiente militar, desde que o ato seja consensual e praticado entre cônjuges ou unidos estavelmente em residência sujeita à administração militar. ${ }^{66}$

\footnotetext{
65 ADPF 291 - Arguição de Descumprimento de Preceito Fundamental (Eletrônico).Disponível em: http://www.stf.jus.br/portal/cms/verNoticiaDetalhe.asp?idconteudo=248739. Acesso em 17 abr. 2015.

${ }^{66}$ PL 6871/2006 e PL 2773/2000. Disponível em: http://www.camara.gov.br. Acesso em 17 abr. 2015.
} 


\subsection{Homossexualidade como doença}

Segundo essa concepção os atos homossexuais são tidos como uma doença (homossexualismo) que acomete o indivíduo, cuja presença o identifica como "homossexual", em contraposição a uma condição normal, tida como saudável, denominada de heterossexualidade.

Temos então o predomínio da mentalidade científica sobre a religiosa.

A consolidação do discurso científico sobre o sexo acontece ao final do século XIX, época em que as pesquisas médicas formalmente deixam a valoração moral das condutas e se centram no sexo como objeto de estudo. O que era visto como imoralidade passou a ser tratado como doença; assim o vício da bebedeira se transformou na doença do alcoolismo, e o pecado da sodomia foi sucedido pelo diagnóstico da perversão sexual. ${ }^{67}$

Em 1869, o médico húngaro Karoly Benkert se manifestou em defesa dos homossexuais que eram perseguidos por questões políticas na Alemanha do Norte. Em carta enviada ao Ministério da Justiça da Alemanha, Karoly Benkert defendia a ideia da homossexualidade como algo inato na pessoa, não podendo ser adquirido e portanto desvinculado das questões de preferência pessoal, e assim, não merecedor de juízos condenatórios por ser classificado como contrário à ordem moral e religiosa. Dessa visão distorcida, mas avançada para a época, tendo em vista vez que dogmas religiosos foram vencidos pela mentalidade científica, decorreu sua classificação como algo anormal a merecer cuidados da ciência médica. Estava criado o termo homossexualismo, e como sendo doença merecia ser tratada. A homossexualidade como doença inseria-se nas denominadas perversões sexuais.

A classificação da homossexualidade como doença serviu, num determinado momento histórico, para proteger os homossexuais contra a tirania estatal e religiosa, que via, no comportamento homossexual, a tipificação de um pecado, e de um crime. Deste modo, passaram os criminosos e pecadores a serem tratados como doentes e naquele

67 RIOS, Roger Raupp. O Princípio da Igualdade e a Discriminação por Orientação Sexual.A Homossexualidade no Direito Brasileiro e Norte-Americano. São Paulo: RT, 2002, p. 105-107. 
momento lhes garantiu uma proteção, mas lhes impingiu o estigma preservado até os dias de hoje. ${ }^{68}$

De acordo com David Greenberg (The construction of homosexuality), a homossexualidade enquanto perversão sexual foi explicada por meio da "teoria da degeneração", pois esta doença seria derivada de uma degeneração na formação pré-natal do indivíduo, pela qual no conflito entre os elementos sexuais masculino e feminino resultava uma inconsistência entre o sexo anatômico e o instinto sexual. Essa teoria teve larga repercussão na criminologia. Utilizando-se de uma analogia entre a narrativa bíblica da queda do homem no paraíso e o postulado de que a natureza humana era degradada pelo impacto do ambiente (doença e desnutrição dos progenitores, por exemplo), sustentou-se a tendência à progressiva morbidez de geração após geração. Como resposta à teoria da degeneração, César Lombroso, com fundamento no darwinismo, defendeu a inadequação funcional dos criminosos na sociedade, em face da etiologia biológica produtora da criminalidade. Esse raciocínio foi aplicado aos homossexuais, gerando políticas estatais de confinamento e castração compulsórias, a fim de se evitar a procriação e em conflito direto com os ideais da criminologia clássica da obra de César Beccaria. Neste contexto de intervenção estatal, o behaviorismo receitou tratamento da homossexualidade por meio de recondicionamento das preferências sexuais, utilizando-se de estímulos adversos associados ao comportamento sexual "desviante", tais como choques elétricos. ${ }^{69}$

No Brasil, Projeto de Decreto Legislativo - PDC 234/2011, de autoria do deputado João Campos-PSDB/GO, popularmente chamado de "Cura Gay", susta a aplicação do parágrafo único do art. $3^{\circ}$ e o art. $4^{\circ}$ da Resolução do Conselho Federal de Psicologia $n^{\circ}$ 1/99 de 23 de março de 1999, que estabelece normas de atuação para os psicólogos em relação à questão da orientação sexual. Tal projeto encontra-se arquivado desde 02 de julho de $2013 .^{70}$

Resolução CPF No 001/99, de 22 de março de $1999^{71}$ :

Art. $3^{\circ}[\ldots]$

${ }^{68}$ GIRARDI, Viviane. Famílias Contemporâneas, Filiação e Afeto. A Possibilidade Jurídica da Adoção por Homossexuais. Porto Alegre: 2005, p. 67-69.

${ }^{69}$ RIOS, Roger Raupp. O Princípio da Igualdade e a Discriminação por Orientação Sexual. A Homossexualidade no Direito Brasileiro e Norte-Americano. São Paulo: RT, 2002, p. 108-109.

${ }_{70}$ Projeto de Decreto Legislativo PDC 234/2011. Disponível em: http://www.camara.gov.br/proposicoesWeb/fichadetramitacao?idProposicao.... Acesso em 23 jul. 2013.

71 Resolução CPF No 001/99. Disponível em: http://site.cfp.org.br/wp-content/uploads/1999/03/resolução 1999_1.pdf. Acesso em 16 nov. 2013. 
Parágrafo único - Os psicólogos não colaborarão com eventos e serviços que proponham tratamento e cura das homossexualidades.

Art. $4^{\circ}$ - Os psicólogos não se pronunciarão, nem participarão de pronunciamentos públicos nos meios de comunicação de massa de modo a reforçar os preconceitos sociais existentes em relação aos homossexuais como portadores de qualquer desordem psíquica.

No entanto, ainda quanto à concepção da homossexualidade como doença, é importante salientar que a validade científica destas ideias sobre a homossexualidade não mais se sustentam.

Registre-se que desde 15 de dezembro de 1973, por decisão da American Psychiatric Association, a homossexualidade foi excluída do rol das doenças mentais. ${ }^{72}$

A Organização Mundial de Saúde (OMS) não classifica a homossexualidade como doença. A referida entidade possui uma publicação mundial, a Classificação Internacional de Doenças (CID). A CID n.9 era de 1975 e identificava a homossexualidade como um diagnóstico psiquiátrico, no capítulo "Das doenças mentais" e no subcapítulo “Dos desvios e transtornos sexuais", sob o n. 302.0. Uma década após, em 1985, a OMS publicou uma circular em que esclarecia que o homossexualismo deixava de ser considerado uma doença por si só. Do capítulo "Das doenças mentais" deveria passar para o dos "Sintomas decorrentes de circunstâncias psicossociais". Isto é, passou a ser considerado um desajustamento social decorrente de discriminação política, religiosa ou sexual. $^{73}$

Porém, só em 1992 a OMS - Organização Mundial da Saúde inseriu-a no capítulo dos Sintomas Decorrentes de Circunstâncias Psicossociais. Na décima revisão do CID n. 10, em 1995, foi nominada entre os transtornos psicológicos e de comportamento associados ao desenvolvimento e orientação sexual (F66), constando uma nota: A orientação sexual por si só não é para ser considerada como um transtorno.

\footnotetext{
${ }^{72}$ AZEVEDO, Álvaro Villaça. União Homoafetiva. Revista Juris da FAAP, ano III, 2011, p. 11.

${ }^{73}$ BRANDÃO, Debora Vanessa Caús. Parcerias Homossexuais. Aspectos Jurídicos. São Paulo: RT, 2002, p. 20.
} 
O sufixo "ismo", que designa doença, foi substituído pelo sufixo "dade", que significa modo de ser. Assim, depois de quase 20 anos, a homossexualidade deixou de ser doença. $^{74}$

O dia internacional contra a Homofobia é celebrado em 17 de maio. A data foi escolhida em lembrança da exclusão da homossexualidade da Classificação Estatística Internacional de Doenças e Problemas Relacionados à Saúde (CID), em 17 de maio de 1990, oficialmente declarada em $1992 .^{75}$

Em março de 2015 a justiça de primeira instância de São Paulo condenou o candidato à Presidência da República Levy Fidelix (PRTB) a uma multa de R\$ 1milhão por danos morais devido a declarações feitas em debate eleitoral no ano anterior. A ação foi movida pela Defensoria Pública de São Paulo. O candidato associou a homossexualidade à pedofilia e afirmou que "gays precisam de atendimento psicológico bem longe daqui". 76

\subsection{Conclusão}

Neste capítulo foram analisados os conceitos sobre a homossexualidade que se formaram ao longo da história. Estes três conceitos: homossexualidade como pecado, homossexualidade como crime e homossexualidade como doença, embora desmistificados pelas mudanças sociais e pesquisas científicas, ainda estão presentes na sociedade e contribuem para a formação do preconceito e da intolerância contra os homossexuais.

O conceito de homossexualidade como pecado vem de uma interpretação bíblica ao longo dos tempos. Embora existam outras interpretações e até mesmo o Sumo Pontífice, Papa Francisco, pregue a tolerância, muitas outras religiões condenam a homossexualidade.

\footnotetext{
${ }^{74}$ DIAS, Maria Berenice. União Homoafetiva. O preconceito \& a Justiça. 5. ed. revista, atualizada e ampliada. São Paulo: Revista dos Tribunais, 2011, p. 48.

75 Conselho Nacional de Justiça (CNJ). Dia Internacional contra a Homofobia. Disponível em: http://www.cnj.jus.br/cc6j. Acesso em 17 mai. 2015.

${ }^{76}$ Justiça condena Levy Fidelix a pagar R\$ 1 milhão por declaração contra gays. Disponível em: http://www.folha.uol.com.br/poder/2015/03/1603549-justica-condena-levy-fidelix-a... Acesso em 17 abr. 2015.
} 
Os dogmas das religiões devem ser respeitados, assim como devem ser respeitados todos os seres humanos na sua dignidade. A intolerância, o ódio, a discriminação não devem fazer parte de qualquer religião. Assim, se uma religião não aceita o casamento entre pessoas do mesmo sexo, como este é entendido como sacramento, tal posicionamento deve ser respeitado.

Por outro lado, o Estado é laico e o casamento é civil e, neste caso, também deve ser respeitada a laicidade do Estado e o motivo pecado jamais poderá ser aceito.

Muitos países ainda criminalizam a homossexualidade com penas que vão da prisão de alguns anos, prisão perpétua e até pena de morte. Com o passar dos tempos a criminalização da homossexualidade foi diminuindo, mas, ainda hoje, 76 países a consideram um crime.

No Brasil, embora a homossexualidade não seja considerada crime, ainda possui resquícios no Código Penal Militar (CPM) em seu artigo 235. Com o objetivo de sanar este problema, há vários projetos de leis e uma ação de Arguição de Descumprimento de Preceito Fundamental (ADPF-291).

O conceito de homossexualidade como doença, num primeiro momento, serviu para proteger os homossexuais da tirania estatal e religiosa que via no comportamento homossexual a tipificação de um pecado e de um crime. Porém, se era considerada uma doença, esta deveria ser tratada e assim advieram os tratamentos desumanos tais como choques elétricos, tratamentos de reversão da sexualidade com hormônios e tantos outros.

Hoje tal conceito está totalmente superado pela comunidade científica e a orientação sexual, por si só, não é considerada um transtorno. Portanto não se deve mais falar em homossexualismo, que designa doença, mas em homossexualidade, que significa um modo de ser.

Infelizmente este conceito de homossexualidade como doença está tão arraigado em alguns Congressistas que foi criado um Projeto de Decreto Legislativo, PDC 234/2011, popularmente intitulado de "Cura Gay", para impedir a aplicação de parte da Resolução do Conselho Federal de Psicologia e permitir terapias para alterar a orientação sexual e tratar a homossexualidade como se fosse uma doença. Felizmente este projeto foi arquivado. 
Neste mesmo sentido, um candidato à Presidência da República, em debate televisivo também manifestou sua opinião pelo tratamento psicológico dos homossexuais.

Enfim, estes pré-conceitos trazidos, por meio dos séculos, pelas gerações, cristalizam o preconceito em cada um de nós. Tal mudança levará tempo, e o papel do Direito é a defesa "de uma sociedade fraterna, pluralista e sem preconceitos", como bem está escrito no Preâmbulo de nossa Constituição da República Federativa do Brasil. 


\section{UNIÃO HOMOSSEXUAL NA LEGISLAÇÃO ESTRANGEIRA}

O ano de 2013 trouxe grandes avanços para os direitos dos homossexuais no continente europeu.

A principal vitória foi o reconhecimento de que toda pessoa tem o direito de formar uma família, não importa se vai escolher um parceiro do sexo oposto ou do mesmo sexo. Tal direito foi estabelecido pela Corte Europeia de Direitos Humanos em 7 de novembro de 2013 e se estende para todos os 47 países europeus. Apenas a Bielorrússia não faz parte do Conselho da Europa e não tem, portanto, obrigação de cumprir as ordens da corte. ${ }^{77}$

O julgamento é um marco na jurisprudência da corte. O tribunal já havia se posicionado no sentido de que os países europeus não são obrigados a permitir que homossexuais se casem, tendo em vista que o assunto é delicado e deve ser deixado para cada país decidir. Dessa vez, os juízes analisaram se, além do casamento, a união civil também deve ser restrita aos casais heterossexuais.

O entendimento firmado foi no sentido de que casais homossexuais têm as mesmas condições que os heterossexuais de estabelecer um relacionamento estável e formar uma união civil. Cabe ao Estado aceitar e reconhecer tais uniões. Os juízes consideraram que, para excluir os homossexuais de uma lei que permita a união civil, o país necessita dar motivos razoáveis, se é que existem. Do contrário, é discriminação.

No final do ano de 2013, no continente europeu, dez países permitiam que os homossexuais se casassem. Eram eles: Bélgica, Dinamarca, França, Islândia, Holanda, Noruega, Portugal, Espanha, Suécia e a Inglaterra, que aprovou legislação sobre o tema em julho de 2013. A Escócia seria o próximo a autorizar o matrimônio entre duas pessoas do mesmo sexo. Na Irlanda, um dos países mais católicos e conservadores da Europa, o governo já anunciou que deve fazer um plebiscito nos próximos anos para ouvir a população sobre o tema. Em 2015, a população se manifestou a favor do casamento entre pessoas do mesmo sexo.

A união civil entre pessoas do mesmo sexo é mais aceita no continente europeu. Além dos que permitem o casamento, outros dezesseis países reconhecem a união estável

${ }^{77}$ PINHEIRO, Aline. Retrospectiva 2013. Gays ganham direito de formar família na Europa. Disponível em: http://www.conjur.com.br/2014-jan-04/ano-2013-conquistas-direitos-homossexuais?i... Acesso em 06 jan. 2014. 
entre duas pessoas do mesmo sexo. Entre esses, apenas três - República Tcheca, Hungria e Eslovênia - são do Leste Europeu.

A Grécia e a Lituânia são os únicos países da Europa, entre aqueles que reconhecem a validade das uniões estáveis, a restringir o direito a casais de sexos diferentes. E foi exatamente a legislação grega que provocou a Corte Europeia de Direitos Humanos a se manifestar sobre o assunto. Em 07 de novembro de 2013, a corte europeia considerou que a lei grega é discriminatória e viola a Convenção Europeia de Direitos Humanos. $^{78}$

Com relação à adoção, a Corte Europeia de Direitos Humanos considerou que impedir que duas pessoas do mesmo sexo adotem um filho só por conta da definição tradicional de família é prática discriminatória. Não há problema algum uma criança ter duas mães ou dois pais. No entanto, manteve entendimento de que podem ser impostas restrições à adoção por casais homossexuais. ${ }^{79}$

A Rússia, que em 2012 aprovou lei impedindo propaganda homossexual, não é a única na tentativa de exterminar a homossexualidade no país. Relatório produzido pelo Conselho da Europa mostra que pelo menos outros quatro países europeus - Ucrânia, Moldávia, Lituânia e Hungria - também tentam criar e manter legislação no mesmo sentido da lei russa. $\mathrm{O}$ argumento usado por eles é basicamente o mesmo: promover o relacionamento entre duas pessoas do mesmo sexo pode prejudicar moralmente as crianças. $^{80}$

Assim, com relação ao casamento, por ordem cronológica de aprovação da legislação temos: $1^{\circ}$ ) Holanda (2001); $2^{\circ}$ ) Bélgica (2003); $3^{\circ}$ ) Espanha (2005); $4^{\circ}$ ) Canadá (2005); 5) África do Sul (2006); 6º Noruega (2009); $7^{\circ}$ ) Suécia (2009); $8^{\circ}$ ) Portugal

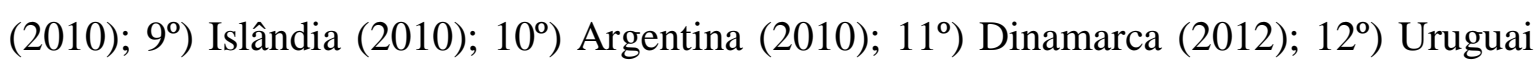

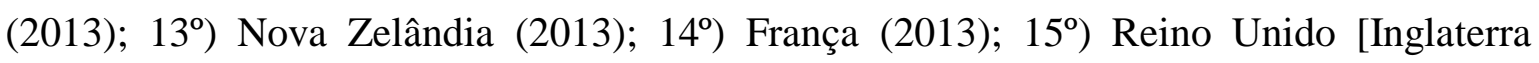
(2013), País de Gales (2013), Escócia (2014)]; 16º Luxemburgo (2014), 17º) Irlanda (2015) e $18^{\circ}$ ) Estados Unidos (2015). Nesta cronologia, deixamos de colocar o Brasil, pois

\footnotetext{
78 PINHEIRO, Aline. Corte europeia reconhece direito de gays formarem família. Disponível em http://www.conjur.com.br/2013-nov-07/gays-tambem-direito-formar-familia-decide-c... Acesso em 06 jan. 2014.

79 PINHEIRO, Aline. Corte Europeia veta regras diferentes para casais gays. Disponível em: http://www.conjur.com.br/2013-fev-19/europa-decide-definicao-tradicional-familia-n... Acesso em 06 jan. 2014.

80 PINHEIRO, Aline. Direito dos gays é pouco reconhecido no Leste Europeu. Disponível em: http://www.conjur.com.br/2013-ago-21/direito-homossexuais-ainda-reconhecido-leste... Acesso em 06 jan. 2014.
} 
ainda não há legislação a respeito do tema. Com relação ao México, a legislação sobre o casamento homossexual é aceita em alguns estados como veremos a seguir.

\subsection{Casamento}

\subsubsection{Holanda}

O Parlamento holandês, no ano de 2000, aprovou a lei que equiparou as uniões homossexuais ao casamento tradicional, por 107 votos contra 33, sob um intenso debate com duração de três dias. Importante ressaltar que independente das discussões de cunho político travadas, as pesquisas realizadas entre os cidadãos holandeses indicavam que $85 \%$ deles eram a favor da aprovação do casamento entre pessoas do mesmo sexo. Ressalte-se que esta lei é completa, permitindo, inclusive, a controvertida adoção por casais homossexuais. $^{81}$

Em $1^{\circ}$ de abril de 2001 entrou em vigor a Lei de 21.12.2000, que garante acesso ao casamento às pessoas do mesmo sexo. Entretanto, o casamento entre pessoas do mesmo sexo não produz o mesmo efeito jurídico em face da filiação, que o casamento entre pessoas de sexo diferente. Quando realizado entre pessoas de sexo diferente gera a presunção de paternidade, enquanto que envolvendo pessoas do mesmo sexo, a filiação só se dará mediante adoção. É, portanto, possível a adoção de menor sendo este filho de seu consorte ou não.

Desde a entrada em vigor da referida lei, é possível a adoção pelo casal homossexual, com algumas limitações, isto é, aos menores de origem holandesa ou que ali residam, assim como o acesso ao outro cônjuge da autoridade parental conjunta dos filhos de seu consorte, desde que só um deles exerça a autoridade parental, tenha o consorte estreita relação afetiva com o menor e seja preservado o melhor interesse da criança.

${ }^{81}$ RODRIGUES, Irene; BÉO, Cíntia Regina. União Homoafetiva: Aspectos Civis e Constitucionais. Revista da Faculdade de Direito da Universidade de São Paulo. Vol. 99, 2004, p. 669. 
Apesar de a lei holandesa autorizar o casamento entre pessoas do mesmo sexo, a adoção conjunta não é permitida, ainda que as lésbicas possam ser inseminadas artificialmente. ${ }^{82}$

Assim, a nova lei introduziu no artigo 30 do código civil holandês um novo parágrafo com o seguinte teor: "Um matrimônio pode ser contratado entre duas pessoas de sexo diverso ou do mesmo sexo". Portanto, a norma deixa claro que o mesmo instituto do casamento é previsto igualmente para pessoas de sexo diferente quanto para pessoas do mesmo sexo. Porém, com relação à filiação, há diferença, pois o legislador holandês não modificou o capítulo 11 do livro primeiro do código civil, que trata da filiação somente entre homem e mulher e considera pai da criança o homem casado com a mãe da criança. Por outro lado, o cônjuge homossexual pode adotar o filho biológico do outro cônjuge. ${ }^{83}$

\subsubsection{Bélgica}

Após ter sido introduzida a coabitação legal em 1998, em 30 de janeiro de 2003 a Bélgica tornou-se, após a Holanda, o segundo ordenamento jurídico no mundo a abrir o acesso ao matrimônio aos casais do mesmo sexo. Na motivação do projeto de lei afirmouse que a concepção tradicional do matrimônio, ou seja, uma comunhão de vida durável entre duas pessoas de sexo diferente tendo como fim primordial a procriação já estava superada, tendo o matrimônio perdido o caráter essencialmente procriativo. A nova lei abrindo o casamento às pessoas do mesmo sexo e modificando certos dispositivos do Código Civil, modificou sobretudo o artigo 143 do Diploma Civil: "Deux personnes de sexe différent ou de même sexe peuvent contracter le mariage". ("Duas pessoas de sexo diferente ou de mesmo sexo podem contrair o matrimônio”. Tradução livre). O matrimônio entre pessoas do mesmo sexo não comporta a aplicação da presunção de paternidade e das normas sobre filiação, pois o modificado artigo 143 do Código Civil Belga prevê no segundo parágrafo que: Si le mariage a été contracté entre des personnes de meme sexe, l'article 315 n'est pas applicable (“Se o matrimônio é realizado entre pessoas do mesmo

\footnotetext{
${ }^{82}$ MALUF, Adriana Caldas do Rego Freitas Dabus. Novas Modalidades de Família na Pós-Modernidade. São Paulo: Atlas, 2010, p. 255-257.

${ }^{83}$ TORINO, Raffaele. La Tutela Della Vita Familiare Delle Coppie Omossexuali. Nel diritto comparato, europeo e italiano. Torino: G.Giappichelli Editore, 2012, p. 39-40.
} 
sexo, o artigo 315 não é aplicável”. Tradução livre). Todavia com a lei de 18 de maio de 2006, que modificou certos dispositivos do Código Civil permitindo a adoção por pessoas do mesmo sexo previu que também os casais formados por pessoas do mesmo sexo (casados, em coabitação legal ou convivente por ao menos 3 anos) possam proceder à adoção de menores. ${ }^{84}$

Tanto para os casais homossexuais, quanto para os casais heterossexuais, os requisitos para contrair matrimônio são iguais. Foi mantido o mesmo sistema de impedimentos, com as mesmas exigências de consentimento e forma de celebração. É necessário que ao menos um dos nubentes seja natural da Bélgica ou residente do país. A lei adotou a solução de que, apesar de a lei reguladora do estatuto pessoal de um dos contraentes não reconheça o matrimônio entre pessoas do mesmo sexo, o mesmo pode ser celebrado. Entretanto, há a ressalva de que tais casamentos poderão não ser reconhecidos em territórios alienígenas. ${ }^{85}$

A lei sobre o matrimônio homossexual, inicialmente não permitia a adoção por casais de mesmo sexo, nem havia a presunção de filiação sobre o filho do outro consorte. Em $1^{\circ}$ de dezembro de 2005, um Projeto de Lei autorizando a adoção por casais do mesmo sexo foi aprovado pela Câmara de Representantes. A lei foi aprovada pela Câmara dos Representantes do Parlamento Federal belga em 2 de dezembro de 2005 e pelo Senado em 20 de abril de 2006, e, após sanção do Rei Albert II em 18 de maio, entrou em vigor em 30 de junho de 2006. A partir de então, os homossexuais podem se casar e adotar conjuntamente na Bélgica. ${ }^{86}$

\subsubsection{Espanha}

O parlamento espanhol aprovou em 30 de junho de 2005 o projeto de lei que permite a celebração do casamento também entre pessoas do mesmo sexo. Segundo o

\footnotetext{
${ }^{84}$ TORINO, Raffaele. La Tutela Della Vita Familiare Delle Coppie Omossexuali. Nel diritto comparato, europeo e italiano. Torino: G.Giappichelli Editore, 2012, p. 41.

85 CHAVES, Marianna. Homoafetividade e Direito. Proteção Constitucional, Uniões, Casamento e Parentalidade. 2. ed. Curitiba: Juruá, 2012, p. 124-125.

86 Mariage homosexuel en Belgique. Disponível em: http://fr.wikipedia.org/wiki/Mariage_homosexuel_en_Belgique. Acesso em 07 jan. 2014.
} 
legislador espanhol, sendo o matrimônio um direito constitucional da pessoa e uma instituição jurídica de relevância social, apesar de ser inicialmente concebido como uma relação jurídica entre pessoas de sexo diferente, não se pode ignorar o fato de que a sociedade se desenvolveu no sentido de reconhecer diversos modelos de convivência. Fundamentou-se na Constituição espanhola que traz a promoção da igualdade efetiva dos cidadãos fundada no livre desenvolvimento da personalidade (art. 9, parágrafo 2 e 10 e parágrafo 1), à tutela da liberdade em relação à forma de convivência (art. 1, parágrafo 1) e também da igualdade no exercício dos direitos, sem qualquer discriminação em razão de sexo, de opiniões ou de quaisquer outras condições pessoais e sociais (art. 14). A abertura do matrimônio aos casais do mesmo sexo foi fortemente contestada em nível jurídico, político e social. Também a Regia Academia de Jurisprudência e Legislação se pronunciou contrária à reforma. O Conselho de Estado sugeria que o legislador optasse por uma regulamentação diferente do casamento. Em sede parlamentar os debates foram acalorados, mas, apesar do veto do Senado a lei n. 13/2005 sem substanciais modificações pela maioria absoluta do pleno do Congresso dos deputados na sessão de 30 de junho, foi finalmente aprovada. A reforma acrescentou um parágrafo ao artigo 44 do Código Civil, que afirma o princípio da igualdade dos efeitos do matrimônio independentemente da diversidade de sexo dos cônjuges. Os termos marido e mulher foram substituídos pelo termo cônjuge. Permitiu-se também a adoção pelos casais homossexuais. A aprovação da Lei n. 13/2005 gerou muita resistência, seja dos funcionários do Estado que deveriam aplica-la os quais alegavam objeção de consciência, seja pelos grupos políticos remanescentes. O Tribunal Superior refutou a objeção de consciência. ${ }^{87}$

Em 2004, o então recém-eleito governo socialista liderado pelo primeiro-ministro José Luis Rodriguez Zapatero, deu início a uma campanha pela legalização do casamento entre pessoas do mesmo sexo, além da adoção homoparental. A legislação espanhola já permitia a adoção por pessoas solteiras; assim, um casal homossexual poderia realizar uma adoção de fato, mas o parceiro que não fosse o guardião legal da criança não tinha direitos sobre ela se o relacionamento acabasse ou se o guardião morresse. Durante as décadas de 1990 e 2000, várias câmaras municipais e comunidades autônomas começaram a fazer registros de uniões civis entre casais do mesmo sexo, embora com efeito meramente simbólico. Os casamentos entre pessoas do mesmo sexo não eram legalizados nas

${ }^{87}$ TORINO, Raffaele. La Tutela Della Vita Familiare Delle Coppie Omossexuali. Nel diritto comparato, europeo e italiano. Torino: G.Giappichelli Editore, 2012, p. 42-45. 
comunidades autônomas, tendo em vista que a Constituição espanhola dá ao Estado competência exclusiva para legislar sobre o casamento.

Após muitos debates, a lei 13/2005 foi aprovada pelas Cortes Gerais - o parlamento bicameral da Espanha, composto pelo Senado e pelo Congresso dos Deputados - em 30 de junho de 2005. Após, o Rei Juan Carlos deu consentimento à lei, sendo esta publicada no Boletin Oficial del Estado, o diário oficial do país, em 2 de julho de 2005. A lei entrou em vigor no dia seguinte, tornando a Espanha o terceiro país do mundo a permitir o casamento entre pessoas do mesmo sexo, após os Países Baixos e a Bélgica e 17 dias antes do Canadá.

A ratificação da lei não ocorreu sem conflitos, embora tivesse o apoio de $66 \%$ da população. Autoridades da Igreja Católica foram terminantemente contra a proposta, criticando-a e temendo o enfraquecimento da instituição casamento. A Igreja não conseguiu apoio suficiente para inviabilizar o projeto de lei, apesar de que $80 \%$ dos espanhóis se declararam católicos. Os sociólogos acreditam que isso se deve ao significativo aumento do liberalismo na esfera dos direitos individuais nos últimos anos, onde a Igreja tradicionalmente mantinha sua influência, especialmente em questões familiares. Uma pesquisa mostrou que três quartos dos espanhóis acreditavam que a Igreja estava desconexa da realidade social.

Outros grupos expressaram a preocupação sobre a possibilidade de casais homossexuais adotarem crianças. Após a aprovação, o conservador Partido Popular questionou a lei no Tribunal Constitucional.

As eleições gerais de novembro de 2011 deram vitória esmagadora para o Partido Popular, que havia questionado a lei no Tribunal Constitucional. Em 06 de novembro de 2012, a lei foi considerada constitucional pelo Tribunal, com 8 votos a favor e 3 contra. $\mathrm{O}$ ministro da Justiça, Alberto Ruiz-Gallardón, anunciou que o governo respeitará a decisão e que a lei não será revogada.

Apesar dos avanços rumo ao igualitarismo, uma falha legal permaneceu na nova legislação: se as crianças fossem geradas num casamento lésbico, a mãe não-biológica, não seria considerada guardiã legal da criança; ela deveria passar pelo longo e caro processo de adoção. Este direito era garantido automaticamente a casais heterossexuais (casados ou não). Em 7 de novembro de 2006, o governo apresentou uma emenda à lei em relação à 
reprodução assistida, permitindo que a mãe não-biológica fosse considerada guardiã junto com sua esposa, que é a mãe biológica. ${ }^{88}$

Sobre a constitucionalidade da Lei 13/2005, há um artigo de bastante profundidade de Guillermo Cerdeira Bravo de Mansilla, professor Titular de Direito Civil da Universidade de Sevilha. ${ }^{89}$

Concluindo:

Na Espanha, durante as décadas de 1990 e 2000 eram feitos registros de uniões civis do mesmo sexo, embora com efeito meramente simbólico nas várias câmaras municipais e comunidades autônomas.

A adoção por pessoas solteiras já era permitida na legislação espanhola, permitindo indiretamente uma adoção de fato aos casais homossexuais sem, contudo, ter direitos sobre a criança aquele que não fosse o guardião.

Eram contrários à legalização do casamento entre pessoas do mesmo sexo autoridades da Igreja Católica, que temiam o enfraquecimento da instituição casamento, e o Partido Popular Conservador.

Em 2004, a campanha pela legalização do casamento entre pessoas do mesmo sexo teve início com o recém-eleito governo socialista liderado pelo primeiro-ministro José Luís Rodrigues Zapatero. Após muitos debates, em 30 de junho de 2005, a lei 13/2005 foi aprovada pelo parlamento bicameral da Espanha composto pelo Senado e pelo Congresso dos Deputados. Em seguida, houve a sanção do Rei Juan Carlos em 2 de julho de 2005, tendo a lei entrado em vigor em 3 de julho de 2005. Assim, a Espanha tornou-se o terceiro país do mundo a permitir o casamento entre pessoas do mesmo sexo após a Holanda e a Bélgica. Porém, em 30 de setembro de 2005 cinquenta deputados do grupo Parlamentar Popular apresentaram um recurso de inconstitucionalidade contra a Lei $n^{\circ} 13 / 2005$ por violação a vários artigos da Constituição. Somente em 06 de novembro de 2012 a lei foi considerada constitucional pelo Tribunal Constitucional.

\footnotetext{
88 Casamento entre pessoas do mesmo sexo na Espanha. Disponível em: http://pt.wikipedia.org/wiki/Casamento_entre_pessoas_do_mesmo_sexo_na_Espanha Acesso em 29 dez. 2013.

${ }^{89}$ MANSILLA, Guillermo Cerdeira Bravo de. Constitucionalidad de la Ley 13/2005, sobre el matrimonio homossexual: Un ejemplo - Hoy- de interpretación sociológica o evolutiva, fundada em razones de igualdad. Revista de Derecho Privado. Marzo-Abril, 2013, p. 25-86.
} 
Percebam que a regulamentação das uniões entre pessoas do mesmo sexo é um assunto polêmico, não só em nosso país, mas também nos demais países do mundo.

Assim, na Espanha a iniciativa partiu do Poder Executivo, sendo votada pelo Poder Legislativo apesar de muitas divergências da Igreja e de partidos políticos. O poder Judiciário ratificou o que decidiram os Poderes Executivo e Legislativo.

\subsubsection{Canadá}

No Canadá, os primeiros passos para a legalização do casamento igualitário também foram dados pelos juízes, tal como na África do Sul, e no Estado de Massachusetts. Na Holanda, na Bélgica e na Espanha a legalização do casamento entre pessoas do mesmo sexo deu-se pela lei.

De fato, o matrimônio entre pessoas do mesmo sexo foi introduzido, em nível federal, com o "Civil Marriage Act" de 2005. O "leading case" em matéria de proibição de discriminação em razão da orientação sexual é representado pelo senhor Egan em 1995 (Egan v. Canada, [1995] 2S.C.R.513), em cujo caso a Corte Suprema canadense declarou a inconstitucionalidade da definição do termo consorte ("spouse") contido na sec. 2 da "Old Age Security Act", na parte em que excluía a possibilidade de compreender um par do mesmo sexo. Embora não houvesse uma expressa referência à orientação sexual, os juízes canadenses julgaram que a norma citada contrastava com a sec. 15 da "Canadian Charter of Rights and Freedoms" de 1982 que vedava a discriminação com relação a sexo, raça, religião e etc. Embora tenha rejeitado o pedido do Sr. Egan, a Corte Suprema canadense afirmou por unanimidade que a orientação sexual é uma característica subjetiva análoga àquela elencada no art. 15 da "Canadian Charter of Rights and Freedom", compreendida no princípio da igualdade em virtude do fato que a homossexualidade é uma característica

profundamente pessoal e imutável ou mutável somente a custos pessoais inaceitáveis. A sentença especificou, além disso, que não somente a sec. 2 da "Old Age Secutiry Act" não era neutra do ponto de vista da orientação sexual, mas que esta terminava por reforçar o estereótipo segundo o qual os homossexuais não podem formar relações duráveis, baseadas na mútua assistência e no mútuo sustento. No caso "Halpern v. Canada" de 2003 a Corte de Apelação de Ontário declarou que a noção de matrimônio presente na "common law", 
da qual emergia o seu caráter heterossexual, violava a sec. 15 da "Canadian Charter of Rights and Freedoms", deduzindo a necessidade de reformulação da definição de matrimônio como "a voluntária união para a vida de duas pessoas, com a exclusão de qualquer outra" e, com relação ao plano administrativo a obrigação imediata de os ofícios competentes concederem licença de matrimônio para os casais homossexuais que houvessem requerido. Ainda em 2003, a Corte de Apelação para British Columbia no caso Barbeau v. British Columbia reconheceu definitivamente a legitimidade do matrimônio homossexual e em 2004, no caso Hendricks e Leboeuf c. Procurador geral de Québec, também a Corte Superior de Québec declarou a inconstitucionalidade da disposição legislativa que impunha a heterossexualidade do matrimônio, reenviando ao legislador provincial a tarefa de uniformizar o quadro normativo de acordo com a constituição. $\mathrm{O}$ exemplo destas três decisões foi seguido por quase todas as outras províncias. Assim, a Federação Canadense entendeu oportuna a adoção de uma legislação em nível nacional que deu origem à "Civil Marriage Act". 90

Tendo em consideração que o casamento é um símbolo importante para todos e em atendimento ao princípio constitucional da igualdade, a chamada Lei do Casamento Civil foi aprovada pelo Parlamento canadense em 28 de junho de 2005 e foi ratificada pelo Senado em 19 de julho do mesmo ano, entrando em vigor em todo o país no dia seguinte. Tornou-se, então, o quarto país do mundo e o primeiro nas Américas a legalizar o casamento entre pessoas do mesmo sexo. É uma lei pequena, composta por apenas quatro artigos e algumas disposições adicionais, cujo núcleo se encontra no artigo $2^{\circ}$, onde está estabelecido que o casamento, no âmbito civil, é a união legítima de duas pessoas com exclusão das demais. A constitucionalidade da Lei do Casamento foi questionada perante o Supremo Tribunal Canadense, que se manifestou pela sua validade. ${ }^{91}$

Não há legislação sobre a adoção para os casais homossexuais, sendo a questão deixada aos legisladores provinciais e ao "case law".

\footnotetext{
${ }^{90}$ TORINO, Raffaele. La Tutela Della Vita Familiare Delle Coppie Omossexuali. Nel diritto comparato, europeo e italiano. Torino: G.Giappichelli Editore, 2012, p. 49-51.

91 CHAVES, Marianna. Homoafetividade e Direito. Proteção Constitucional, Uniões, Casamento e Parentalidade. 2. ed. Curitiba: Juruá, 2012, p. 126.
} 


\subsection{5 África do Sul}

A África do Sul representa um claro exemplo em que a jurisprudência conduziu ao reconhecimento pela via legal do casamento entre pessoas do mesmo sexo. O provimento legislativo, o "Civil Union Act" de 2006, é consequência direta da decisão da Corte Constitucional sul africana em um caso por ela examinado. A Constituição da África do Sul foi a primeira do mundo a dispor expressamente a proibição de discriminação fundada sobre a orientação sexual, artigo 9 , parágrafo $3 .^{92}$

A atual Constituição sul-africana inspirou-se, dogmaticamente, no neoconstitucionalismo, pretendendo além de constituir um Estado Democrático de Direito, construir também uma sociedade pautada em valores democráticos, assim como em direitos humanos. No neoconstitucionalismo coube às Cortes Constitucionais um papel de destaque dentro do Estado Democrático de Direito. ${ }^{93}$

Ensina Vanice Regina Lírio do Valle que o neoconstitucionalismo tem como destaque sua abertura aos valores e princípios jurídicos, também sendo chamado de constitucionalismo ético. Preconiza-se a centralidade da figura argumentativa do juiz na garantia e promoção dos direitos fundamentais. ${ }^{94}$

Na África do Sul, a Corte Constitucional cumpriu papel de grande importância no reconhecimento do casamento entre pessoas do mesmo sexo, como decorrente da efetivação do princípio da isonomia.

O caso Fourie, decidido em 2005, possibilitou à Corte Constitucional sul-africana decidir sobre o reconhecimento do casamento entre pessoas do mesmo sexo. Em rápida síntese, as litigantes Marie Fourie e Cecilia Bonthuys ajuizaram ação para que fosse registrada tal união, uma vez que mantinham uma relação estável há mais de 10 anos, além do reconhecimento de todas as consequências jurídicas, inerentes a um casamento heteroafetivo. O Supremo Tribunal de Apelações negou o pedido das autoras, não

\footnotetext{
${ }^{92}$ TORINO, Raffaele. La Tutela Della Vita Familiare Delle Coppie Omossexuali. Nel diritto comparato, europeo e italiano. Torino: G.Giappichelli Editore, 2012, p. 53.

${ }^{93}$ SOUZA, Thiago Serrano Pinheiro de. O Papel das Cortes Constitucionais Brasileira e Sul-Africana no Reconhecimento da União Homoafetiva. Revista Brasileira de Direito das Famílias e Sucessões. IBDAFAM. Out/Nov. Vol. 36, 2013, p. 100.

${ }^{94}$ VALLE, Vanice Regina Lírio do (org.). Ativismo judicial e o Supremo Tribunal Federal: laboratório de análise jurisprudencial do STF. Curitiba: Juruá, 2009, p. 107.
} 
ordenando o registro, nos termos da Lei do Matrimônio de 1961. Assim, foi elaborado o recurso, sendo este submetido à Corte Constitucional.

O Ministro-Relator Albie Sachs iniciou seu voto com dois questionamentos. O primeiro: a ausência normativa pode ser utilizada para negar igual proteção aos casais homossexuais e mais, tal fato acarretaria discriminação injusta em decorrência da orientação sexual? O segundo: qual remédio deveria ser utilizado pela Corte, caso esta se pronunciasse favoravelmente ao casamento entre pessoas do mesmo sexo?

Com relação à ausência normativa, não se deve cogitar de ausência normativa, mas de simples omissão, não vedando a lei o casamento entre pessoas do mesmo sexo. Ao se pensar de forma distinta, conspira-se contra preceitos constitucionais de primeira grandeza, tais como o princípio da igualdade, e a vedação de discriminação injusta. Assim, pela análise da Constituição da África do Sul (1996), resta claro sua opção de refutar condutas discriminatórias, tendo em vista a premissa de que todos são iguais perante a lei e têm direito à igual proteção, sendo injusta e inconstitucional a segregação baseada na orientação sexual. Mesmo não havendo um direito fundamental ao casamento, a própria Constituição sul-africana proíbe qualquer interferência no direito de se casar ou de constituir uma família. $\mathrm{O}$ argumento de que os homossexuais são indignos para a constituição de entidades familiares, desrespeita a afetividade na formação de suas parcerias, além de reforçar preconceitos e estereótipos. Assim, a discriminação baseada na orientação sexual viola a dignidade humana.

Com relação ao remédio a ser utilizado pela Corte, o Estado Sul-Africano afirmou, em seu recurso, que a Corte Constitucional não teria o poder para redefinir o espectro da Lei do Matrimônio, uma vez que somente o Poder Legislativo teria a mencionada prerrogativa. Assim, a Corte Constitucional sul-africana, por maioria de votos, determinou, que o Legislativo no prazo de um ano, a contar da data do julgamento, sanasse a inconstitucionalidade e regulasse a matéria, suspendendo a declaração de nulidade. Porém, caso o Poder Legislativo não cumprisse a relatada decisão, dentro do prazo estabelecido, seria considerada plenamente efetiva a modificação da Lei do Matrimônio para permitir o casamento entre pessoas do mesmo sexo. Em 14 de novembro de 2006, o Parlamento editou nova lei sobre o matrimônio, cujo objetivo foi acabar com a 
discriminação perpetrada pela antiga norma infraconstitucional, respeitando a decisão da Corte Suprema. $^{95}$

Assim, em novembro de 2006, a África do Sul se tornou o primeiro e único pais do continente africano a legalizar a união entre pessoas do mesmo sexo, por meio do casamentou ou da união civil.

Quanto à adoção homoparental, em setembro de 2002, o Tribunal Constitucional da África do Sul permitiu que os casais de pessoas do mesmo sexo terão o direito à adoção. A decisão foi fundamentada na Constituição do pós-Apartehid, que bane toda e qualquer forma de discriminação baseada na orientação sexual. ${ }^{96}$

Porém, defensores dos direitos humanos dizem que um número crescente de lésbicas foi vítima dos chamados "estupros corretivos", que supostamente têm a intenção de "consertar" a orientação sexual delas.

O "estupro corretivo" é baseado na noção absurda e falsa de que lésbicas podem ser estupradas para "se tornarem heterossexuais", mas este ato horrendo não é classificado como crime de discriminação na África do Sul. As vítimas geralmente são mulheres homossexuais, negras, pobres e profundamente marginalizadas. Até mesmo o estupro grupal e o assassinato de Eudy Simelane, heroína nacional e estrela da seleção feminina de futebol da África do Sul em 2008, não mudou a situação. ${ }^{97}$

\subsubsection{Noruega}

A Noruega se tornou o primeiro país escandinavo e o sexto país do mundo a legalizar o casamento entre pessoas do mesmo sexo.

\footnotetext{
${ }^{95}$ SOUZA, Thiago Serrano Pinheiro de. O Papel das Cortes Constitucionais Brasileira e Sul-Africana no Reconhecimento da União Homoafetiva. Revista Brasileira de Direito das Famílias e Sucessões. IBDFAM. Out/Nov. Vol. 36, 2013, p. 108-120.

96 Adoção Homoparental. Disponível em: http://pt.wikipedia.org/wiki/Ado\%C3\%A7\%C3\%A3o homoparental. Acesso em 18 abr. 2015.

${ }^{97}$ Estupros Corretivos na África do Sul contra Mulheres Lésbicas. Disponível em: http://www.defesadamulher.com.br/estupros-na-africa-do-sul-contra-mulhe... Acesso em 07 jan. 2014.
} 
Uma lei de $1^{\circ}$ de janeiro de 2009, o "Gender Neutral Marriage Act”, coloca em igualdade os casais homossexuais e heterossexuais, tanto para o casamento e a adoção de crianças quanto a possibilidade de recorrerem à reprodução assistida.

O Parlamento, após vários debates, aprovou com 84 votos contra 41 a nova lei do casamento sexualmente neutro, sancionada pelo Rei Haarald, garantindo os mesmos direitos dos casais heterossexuais, destacando-se o direito de adoção, o acesso às técnicas de reprodução assistida e o estabelecimento de presunção de paternidade/maternidade ao outro cônjuge, quando da reprodução medicamente assistida.

Desde 1993, o reconhecimento das relações entre pessoas do mesmo sexo dava-se pela parceria civil, denominada "partenariat", pela Lei $\mathrm{n}^{\circ} 40$ de $1^{\circ}$ de agosto de 1993 . O país se tornou o segundo a fazê-lo, depois da Dinamarca, que implementou uma lei de parceria registrada em 1989. Parecerias registradas concediam praticamente todas as proteções, responsabilidades e benefícios do casamento, incluindo o regime de ruptura da relação, embora com algumas limitações com relação à filiação, pois não permitia a adoção nem o acesso às técnicas de reprodução assistida, permitindo, no entanto, a partilha da autoridade parental entre os parceiros. ${ }^{98}$

A nova lei permite que a Igreja Nacional Luterana ou qualquer outra comunidade religiosa autorizada na Noruega case casais homossexuais, mas não as obriga a tal.

Será a Igreja Luterana que decidirá como proceder nos casos em que determinados pastores se recusarem a celebrar casamentos entre pessoas do mesmo sexo.

O ponto mais polêmico da lei é o que permite que casais de lésbicas, assim como já acontece com os casais heterossexuais, obtenham ajuda financeira do Governo para tratamento de inseminação artificial assistida.

No entanto, a mesma lei permite que profissionais da área de saúde se abstenham de participar dessas operações por motivos éticos. ${ }^{99}$

\footnotetext{
${ }^{98}$ MALUF, Adriana Caldas do Rego Freitas Dabus. Novas Modalidades de Família na Pós-Modernidade. São Paulo: Atlas, 2010, p.253-254.

99 Parlamento Norueguês aprova casamento gay e adoção por homossexuais. Disponível em: http://g1.globo.com/Noticias/Mundo/0,,MUL604456-5602,00.html. Acesso em 04 jan. 2014.
} 


\subsubsection{Suécia}

A Suécia permite que os homossexuais se casem, inclusive no religioso, desde $1^{\circ}$ de maio de 2009. A decisão significa que o gênero não tem mais impacto sobre a possibilidade de casar. Assim, a Suécia se tornou o sétimo país do mundo a permitir o casamento entre pessoas do mesmo sexo.

A união civil de homossexuais, lei sobre a parceria registrada, é reconhecida desde 1995, e em 2003 foi legalizado o direito à adoção. ${ }^{100}$

Em $1^{\circ}$ de fevereiro de 2003, a Suécia tornou-se o segundo país europeu a legalizar em nível nacional a adoção por casais de homossexuais. Sob a nova lei, os casais homossexuais em parcerias registradas têm os mesmos direitos que casais de pessoas do sexo oposto de se candidatarem a pais adotivos. Adicionalmente, parceiros reconhecidos legalmente e coabitantes do mesmo sexo são também válidos para comporem famílias de acolhimento. ${ }^{101}$

\subsubsection{Portugal}

Inicialmente a questão do casamento entre pessoas do mesmo sexo foi levada ao Tribunal Constitucional em 2009 por meio do pedido de duas mulheres que pretendiam contrair matrimônio. O recurso apresentado ao Tribunal Constitucional tinha como objeto a inconstitucionalidade do artigo 1.557 do Código Civil português, que define o casamento: "O casamento é o contrato celebrado entre duas pessoas de sexo diferente que pretendem formar uma família mediante uma plena comunhão de vida”. Os fundamentos eram os artigos 13.2 da Constituição portuguesa que proíbe a discriminação com base na orientação sexual, o artigo 36 que consagra o direito fundamental de contrair casamento e constituir uma família e o artigo 67 sobre a tutela constitucional do vínculo familiar. A conclusão do

100 Casamento homossexual e adoção por casais gays no mundo. Disponível em: http://noticias.terra.com.br/mundo/europa/casamento-homossexual-e-adocao-por-casa Acesso em 07 jan. 2014.

101 Adoção homoparental. Disponível em: http://pt.wikipedia.org/wiki/Ado\%C3\%A7\%C3\%A30_homoparental Acesso em 10 jan. 2014. 
Tribunal Constitucional foi no sentido de que a Constituição portuguesa não impõe uma interpretação do matrimônio exclusivamente heterossexual, nem obrigatoriamente aberta ao homossexual e tudo dependerá da noção que a sociedade atual atribui ao casamento. Portanto o artigo do código civil 1.557 não era inconstitucional e que caberia unicamente ao legislador, único sujeito legitimado institucionalmente a fazê-lo, a tarefa de modificar a norma do ordenamento. ${ }^{102}$

Após inúmeros debates a Assembleia da República aprovou com 126 votos a favor, 97 contra e 7 abstenções no dia 8 de janeiro de 2010, o acesso ao casamento civil entre pessoas do mesmo sexo em Portugal, excluindo-se a adoção.

A lei foi aprovada na especialidade no dia 11 de fevereiro de 2010 e analisada pelo Tribunal Constitucional que não viu problemas de constitucionalidade em 8 de abril.

Em 17 de maio, o Presidente da República, Aníbal Cavaco Silva, promulgou a Lei $n^{\circ}$ 9/2010, que foi publicada no Diário da República em 31 de maio de 2010, e entrou em vigor no dia 5 de junho de 2010. Deste modo, Portugal passou a ser o oitavo país do mundo a realizar em todo território nacional casamentos civis entre pessoas do mesmo sexo. $^{103}$

No primeiro semestre de 2013, Portugal aprovou projeto de lei o qual permite que, nos relacionamentos homossexuais, "quando duas pessoas do mesmo sexo sejam casadas ou vivam em união de fato, exercendo um deles responsabilidades parentais em relação a um menor, por via da filiação ou adoção, pode o cônjuge ou o unido de fato co-adotar o referido menor". Nos termos do diploma legislativo aprovado, podem co-adotar pessoas com mais de 25 anos e nas situações em que não exista "um segundo vínculo de filiação em relação ao menor". Porém, a adoção plena, que permitiria aos casais homossexuais adotarem uma criança juntos, ainda é proibida. O Projeto ainda terá que ser discutido na especialidade e haverá votação final global. ${ }^{104}$

\footnotetext{
${ }^{102}$ TORINO, Raffaele. La Tutela Della Vita Familiare dele Coppie Omosessuali. Nel Diritto Comparato, Europeo e Italiano. Torino: G. Giappichelli Editore, 2012, p. 46-47.

103 Casamento homossexual e adoção por casais gays no mundo. Disponível em: http://pt.wikipedia.org/wiki/Casamento_entre_pessoas_do_mesmo_sexo_em_Portugal Acesso em $28 \mathrm{dez}$. 2014.

104 Portugal torna-se o quinto país a aprovar co-adopção por casais homossexuais. Disponível em: http://www.publico.pt/politica/noticia/parlamento-aprova-coadopcao-homossexual-15... Acesso em 11 jan. 2014.
} 
A segunda votação foi então adiada e optou-se por antes submeter o caso ao referendo popular. No entanto, o Tribunal Constitucional lusitano considerou a consulta ilegal devido ao conteúdo das perguntas que seriam submetidas a sufrágio e o texto retornou novamente ao parlamento. Assim, dez meses depois de ter sido aprovado o direito dos casais homossexuais à coadoção, o parlamento português rejeitou em março de 2014 essa possibilidade com o voto contra da maioria de deputados conservadores. ${ }^{105}$

Portanto, aos casais homossexuais em Portugal é permitido apenas o casamento e não é permitida a adoção.

Com relação à teoria do casamento inexistente devido à diversidade de sexos, Portugal legislava ${ }^{106}$ no inciso "e" do artigo 1.628 que "é juridicamente inexistente o casamento contraído por duas pessoas do mesmo sexo". E concluía no artigo 1.630 que "o casamento juridicamente inexistente não produz qualquer efeito jurídico e nem sequer é havido como putativo".

Assim, o Código Civil Português ${ }^{107}$, que em matéria de negócios jurídicos alude somente à nulidade e anulabilidade (artigos 285 a 294) - legisla sobre a inexistência somente com relação ao casamento (artigos. 1.628 a 1.630).

Importante notar que a Lei $9 / 2010^{108}$, publicada no dia 31 de maio de 2010 , que permite o casamento civil entre pessoas do mesmo sexo, em seu artigo $2^{\circ}$ alterou os artigos 1.577, 1.591 e 1.690 do Código Civil; no artigo $3^{\circ}$ alterou a redação sobre a adoção e no artigo $4^{\circ}$ revogou a alínea e) do artigo $1.628^{\circ}$ passando a terem a seguinte redação: “Artigo 1.577 [...] Casamento é o contrato celebrado entre duas pessoas que pretendem constituir

105 Parlamento português rejeita adoção por casais homossexuais. Disponível em: http://exame.abril.com.br/mundo/noticias/parlamento-portugues-rejeita-adocao-por-ca... Acesso em 21 abr. 2015.

${ }^{106}$ Artigo $1628^{\circ}$ (Casamentos Inexistentes). É juridicamente inexistente: a) O casamento celebrado perante quem não tinha competência funcional para o acto, salvo tratando-se de casamento urgente; b) $\mathrm{O}$ casamento urgente que não tenha sido homologado; c) $\mathrm{O}$ casamento em cuja celebração tenha faltado a declaração da vontade de um ou ambos os nubentes, ou do procurador de um deles; d) O casamento contraído por intermédio de procurador, quando celebrado depois de terem cessado os efeitos da procuração, ou quando esta não tenha sido outorgada por quem nela figura como constituinte, ou quando seja nula por falta de concessão de poderes especiais para o acto ou de designação expressa do outro contraente; e) O casamento contraído por duas pessoas do mesmo sexo. Artigo $1630^{\circ}$ (Regime da Inexistência). 1. O casamento juridicamente inexistente não produz qualquer efeito jurídico e nem sequer é havido como putativo. 2. A inexistência pode ser invocada por qualquer pessoa, a todo o tempo, independentemente de declaração judicial.

107 Código Civil Português. Disponível em: http://www.confap.pt/docs/codcivil.PDF. Acesso em 26 ago. 2013.

${ }^{108}$ Lei 9/2010. Disponível em: http://dre.pt/pdf1s/2010/05/10500/0185301853.pdf Acesso em 19 ago. 2013. 
família mediante uma plena comunhão de vida, nos termos das disposições deste Código." Artigo 1.591 “[...] O contrato pelo qual, a título de esponsais, desposórios ou qualquer outro, duas pessoas se comprometem a contrair matrimônio não dá direito a exigir a celebração do casamento, nem a reclamar, na falta de cumprimento, outras indenizações que não sejam as previstas no artigo 1.594, mesmo quando resultantes de cláusula penal”. Artigo 1.690 “[...] 1 - Qualquer dos cônjuges tem legitimidade para contrair dívidas sem o

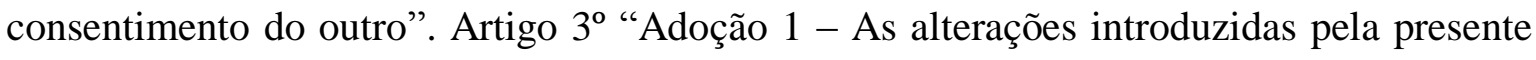
lei não implicam a admissibilidade legal da adoção, em qualquer das suas modalidades, por pessoas casadas com cônjuge do mesmo sexo. 2 - Nenhuma disposição legal em matéria de adoção pode ser interpretada em sentido contrário ao disposto no número anterior". Artigo $4^{\circ}$ - "É revogada a alínea "e" do artigo $1.628^{\circ}$ do Código Civil".

Desta forma, podemos concluir que a diversidade de sexo não é mais requisito para se configurar o casamento inexistente em Portugal, sendo mantidos os demais requisitos que são a falta de celebração e ausência total de consentimento. Assim, a teoria da inexistência do casamento restou modificada em Portugal.

\subsubsection{Islândia}

O Parlamento da Islândia, único país do mundo a ter uma pessoa abertamente homossexual como chefe de Estado, aprovou em 27 de junho de 2010, por unanimidade, a lei que autoriza o casamento entre pessoas do mesmo gênero. Deste modo, a Islândia tornou-se o nono país no mundo a legalizar o casamento homossexual.

A Islândia é uma nação socialmente tolerante, com cerca de 320 mil habitantes. Em 2009, a social-democrata Johanna Siguròardóttir, lésbica, foi indicada por seu partido e se tornou primeira-ministra. A orientação sexual da primeira-ministra atraiu mais atenção da mídia estrangeira do que na própria Islândia, onde nas últimas duas ou três décadas há uma tolerância cada vez maior com a homossexualidade. ${ }^{109}$

109 Parlamento da Islândia aprova casamento gay por unanimidade. Disponível em: http://oglobo.globo.com/mundo/parlamento-da-islandia-aprova-casamento-gay-por-un Acesso em 10 jan. 2014. 
Até então, os casais homossexuais contavam com outro tipo de reconhecimento legal. Em 04 de junho de 1996, foi aprovada a Lei de Parceria Registrada na Islândia, com apenas um voto contra e uma abstenção. A normativa é similar às leis da Suécia, Noruega e Dinamarca, em relação ao processo de registro e as consequências legais. Após a aprovação da lei sobre o casamento homossexual, a Lei de Parceria Registrada não mais subsiste. ${ }^{110}$

No dia 2 de junho de 2006, o Parlamento Islandês aprovou várias medidas om o intuito de melhorar o estado legal de gays e lésbicas na Islândia, passando a garantir direitos totais de adoção, reforçando a co-adoção introduzida em 2000 e o acesso à procriação medicamente assistida para lésbicas dentro do sistema público de saúde, após a total equiparação da referida união ao casamento. A nova lei entrou em vigor no dia 27 de junho de 2006, tornando a Islândia o segundo país escandinavo a reconhecer na íntegra os direitos e deveres da homoparetalidade. ${ }^{111}$

\subsubsection{Argentina}

Com a Lei n. 26.618, sancionada em 15 de julho de 2010 e, promulgada em 21 de julho de 2010, a Argentina tornou-se o primeiro país da América Latina a permitir o casamento entre pessoas do mesmo sexo. A nova lei, composta de 43 artigos, substitui todas as expressões contidas no código civil e nas outras leis que fazem referência ao sexo dos cônjuges com outras expressões "gender-neutral". O artigo 42 desta lei demonstra a plena equiparação entre o matrimônio contraído por pessoas de sexo diferente, e o contraído por pessoas do mesmo sexo. Artigo 42. - "Todas as referências à instituição do matrimônio que contem nosso ordenamento jurídico se entendem aplicáveis tanto ao matrimonio constituído por duas (2) pessoas do mesmo sexo como ao matrimônio constituído por duas (2) pessoas de sexo diferente. Os integrantes das famílias cuja origem seja um matrimônio constituído por duas (2) pessoas do mesmo sexo, assim como um matrimônio constituído por pessoas de sexo diferente, terão os mesmos direitos e

110 CHAVES, Marianna. Homoafetividade e Direito. Proteção Constitucional, Uniões, Casamento e Parentalidade. 2. ed. Curitiba: Juruá, 2012, p. 149.

111 Adoção Homoparental. Disponível em: http://pt.wikipedia.org/wiki/Ado\%C3\%A7\%C3\%a3o_homoparental Acesso em 10 jan. 2014. 
obrigações. Nenhuma norma do ordenamento jurídico argentino poderá ser interpretada nem aplicada no sentido de limitar, restringir, excluir ou suprimir o exercício ou gozo dos mesmos direitos e obrigações, tanto ao matrimônio constituído por pessoas do mesmo sexo como ao formado por duas (2) pessoas de sexo diferente". ${ }^{112}$

Da leitura do artigo 42 acima, depreende-se que a filiação homoparental é permitida na Argentina, tanto pela adoção quanto pela reprodução assistida.

O debate sobre a legislação que autoriza o casamento entre pessoa do mesmo sexo na Argentina começou a partir da campanha nacional pela igualdade legal, lançada pela Federação Argentina de Lésbicas, Gays, Bissexuais e Trans, sob o lema "Os mesmos direitos, com os mesmos nomes". 113

Com a aprovação do casamento homossexual na Espanha, em 30 de junho de 2005, o deputado federal Eduardo Di Pollina, do Partido Socialista, decidiu apresentar um projeto de lei para habilitar o casamento entre pessoas do mesmo sexo na Argentina. Tal projeto de lei deu entrada na Câmara dos Deputados em 2 de dezembro de 2005. Porém, nunca chegou a ser debatido, nem sequer em comissão. Em 2007, foi reproduzido com algumas modificações e apresentado novamente por Di Polina, junto com outros deputados, e em 2009 ingressou pela última vez, encabeçado pela assinatura de Silvia Augsburger. A terceira vez foi a última: o projeto apresentado por Augsburger em 2009 baseado no de Di Pollina - junto com outro projeto, da senadora Vilma Ibarra, foi a base da lei do casamento igualitário aprovado pelo Senado em 14 de julho de 2010.

O projeto, apesar da mudança profunda que propunha, era muito simples: não se trata de uma nova figura, diferente da do casamento atual, mas se limita a modificar dois artigos do Código Civil: 172 e188. Substituindo-se "homem e mulher" por "contraentes" no artigo 172 e no artigo 188 a frase "tomar-se por marido e mulher" por "constituir-se em cônjuges".

Em 14 de fevereiro de 2007, Maria Rachid e Cláudia Castro, que já viviam em união civil desde 21 de agosto de 2003, após a sanção da lei municipal 1.004 da cidade de

\footnotetext{
112 TORINO, Raffaele. La Tutela Della Vita Familiare Delle Coppie Omossexuali. Nel diritto comparato, europeo e italiano. Torino: G.Giappichelli Editore, 2012, p. 57-58.

113 Casamento entre pessoas do mesmo sexo na Argentina. Disponível em: http://pt.wikipedia.org/wiki/Casamento_entre_pessoas_do_mesmo_sexo_na_Argentina. Acesso em $28 \mathrm{dez}$. 2013.
} 
Buenos Aires, foram até o Registro Civil da rua Uruguai, 753, em Buenos Aires e deram entrada num pedido para se casar, com o objetivo de contrair matrimônio como qualquer pessoa.

A data escolhida não era casual: 14 de fevereiro, dia de São Valentim. Era uma boa isca para a imprensa: "No Dia dos Namorados, um casal de lésbicas dá entrada num pedido de casamento". Acionada a imprensa, Maria e Cláudia dirigiram-se ao Cartório, mas foram informadas de que não poderiam se casar, tendo em vista que a lei não permite. No dia seguinte, a notícia estava em todos os jornais, contendo opiniões divididas entre os juristas. Trazia, no entanto declarações favoráveis de Beatriz Rajland, advogada e titular da cátedra de Teoria do Estado da Universidade de Buenos Aires.

Após, Maria e Cláudia apresentaram na Justiça uma ação de amparo, que é um instrumento previsto no artigo 43 da Constituição argentina o qual permite que os cidadãos recorram para a proteção de direitos individuais, coletivos e difusos e é semelhante ao que no Brasil se conhece como mandado de segurança, porém, mais amplo e, segundo alguns juristas, mais eficiente. O recurso caiu, por sorteio, na $88^{\mathrm{a}}$ Vara Cível de Buenos Aires, a cargo da juíza María Bacigalupo, e foi protocolado com o número 6.631/2007. Assim, a Federação Argentina de Lésbicas, Gays, Bissexuais e Trans lançava uma campanha nacional pelo reconhecimento desse direito, da qual o recurso seria apenas o primeiro passo. $^{114}$

O recurso pedia que fosse declarada a inconstitucionalidade dos artigos 172 e 188 do Código Civil. O primeiro dizia, na redação anterior à lei do casamento igualitário, que “é indispensável para a existência do casamento o pleno e livre consentimento expresso pessoalmente por homem e mulher diante da autoridade competente para celebrá-lo", e o segundo que "no ato da celebração do casamento, o oficial público lerá aos futuros esposos os artigos 198, 199 e 200 deste Código, recebendo de cada um deles, um depois do outro, a declaração de que querem respectivamente se tomar por marido e mulher, e pronunciará em nome da lei que ficam unidos em matrimônio".

Sustentava-se que esses artigos violavam os princípios de igualdade perante a lei, não discriminação, liberdade individual e reserva dos atos privados e o direito a contrair matrimônio, à livre associação e à proteção integral da família, consagrados na

\footnotetext{
${ }^{114}$ BIMBI, Bruno. Casamento Igualitário. Tradução de Rosanne M. Nascimento de Souza. Rio de Janeiro: Garamond, 2013, p. 17-32.
} 
Constituição nacional e nos tratados internacionais de Direitos Humanos com valor constitucional desde a reforma de 1994.

Porém, os opositores sustentavam que a união civil não era discriminatória e que o casamento estava inteiramente ligado à ideia de sacramento, e, portanto, deveriam ser institutos distintos com os mesmos direitos.

A união civil foi um avanço na cidade de Buenos Aires, mas propor a união civil em nível nacional parecia uma contradição. O casamento é um contrato e nós queremos poder celebrá-lo com os mesmos direitos. E com o mesmo nome, porque quando nós gays assinamos um contrato de aluguel, ele não se chama "união civil de locação de imóvel" e quando as lésbicas assinam um contrato de trabalho, ele não é chamado de "parceria com o patrão". Assim, quando nos casamos, queremos que se chame casamento. ${ }^{115}$

Sobre a ação de Maria e Cláudia, a juíza María Bacigalupo declarou-se incompetente, já que, em sua opinião, a decisão cabia à justiça contencioso-administrativa da cidade, uma vez que a parte demandada era o Registro Civil - dependente da prefeitura - por não ter dado entrada ao pedido do casal. Houve recurso e este foi acatado. Porém, todos os pedidos apresentados à justiça contencioso-administrativa foram aceitos. Foi assim que se casaram Alejandro Freyre e José María Di Bello, o primeiro casamento gay argentino. Os casamentos que, em efeito dominó, começaram a ser celebrados depois, autorizados pelos juízes do foro contencioso-administrativo portenho, mudaram as condições do debate que levaria à aprovação da lei em julho de 2010.

Ensina a professora argentina Ursula C. Basset, que a Lei 26.618, sancionada em 15 de julho de 2010, modificou 35 artigos do Código Civil argentino que implicaram alteração nos quatro livros que integram o Código Civil. As modificações consistiram fundamentalmente na troca de termos que suprimam a diferença sexual do texto, sobretudo quando aludem a um contexto relacional familiar. A diferença feminino-masculino deixa de produzir efeitos jurídicos. O critério adotado é o da neutralidade de gênero.

Para a doutrinadora argentina, a modificação da legislação do matrimônio restou incompleta. Aponta vários problemas dentre os quais o regime da filiação, pois agora serão previstos de três a quatro progenitores (um doador de esperma, outra doadora de óvulos,

\footnotetext{
${ }^{115}$ BIMBI, Bruno. Casamento Igualitário. Tradução de Rosanne M. Nascimento de Souza. Rio de Janeiro: Garamond, 2013, p. 25-67.
} 
uma mãe gestatriz, etc.). A lei deve determinar onde se assenta a paternidade legal baseada no interesse do menor. Os conflitos de interesses podem determinar a existência de dois pais e uma mãe (se o menor quiser determinar sua maternidade em caso de pares de dois homens). Assim uma criança poderia, então, ter seis avós, doze bisavós, etc.. Haveria direitos hereditários com relação a todos estes parentes, e direitos e deveres alimentares com relação a todos os parentes. Será necessária uma cuidadosa reelaboração de todo o direito e as novas relações que emergirão.

Além disto, a teoria da inexistência deverá ser reformulada para ser adaptada ao novo matrimônio. Outro problema é que não há legislação sobre a reprodução assistida. E conclui que não está clara qual será a evolução de tais mudanças a curto, médio e longo prazo. $^{116}$

A figura do casamento inexistente é admitida na Argentina, dispondo o art. 172 do Código Civil, antes da modificação pela lei 26.618, de 05 de julho de 2010, que:

É indispensável para a existência do matrimônio o pleno e livre consentimento expressado pessoalmente pelo homem e pela mulher ante a autoridade competente para celebrá-lo. A segunda parte deste artigo prevê que o ato que carecer de alguns destes requisitos não produzirá efeitos civis, ainda que as partes tenham agido de boa-fé. ${ }^{117}$

Após a modificação, o art. 172 ficou com a seguinte redação:

É indispensável para a existência do matrimônio o pleno e livre consentimento expressado pessoalmente por ambos contraentes ante a autoridade competente para celebrá-lo. O matrimônio terá os mesmos requisitos e efeitos, independentemente de que os contraentes sejam de mesmo ou de diferente sexo. $\mathrm{O}$ ato que carecer de algum destes requisitos não produzirá efeitos civis mesmo que as partes estejam de boa-fé, salvo o disposto no artigo seguinte. ${ }^{118}$

Com a nova redação do Código Civil e Comercial argentino, os requisitos da existência do matrimônio estão previstos no artigo 406:

Requisitos da existência do matrimônio. Para a existência do matrimônio é indispensável o consentimento de ambos contraentes expressado pessoal e conjuntamente ante a autoridade competente para celebrá-lo,

\footnotetext{
${ }^{116}$ BASSET, Ursula C. El cambio de paradigma de la nueva ley argentina sobre el matrimonio. In Direito e Dignidade da Família. Do começo ao fim da vida. Org. Antonio Jorge Pereira Júnior, Débora Gozzo, Wilson Ricardo Ligiera. São Paulo: Almedina, 2012, p. 187-204.

${ }^{117}$ VELOSO, Zeno. Nulidade e inexistência. In 10 anos de Vigência do Código Civil Brasileiro de 2002. Estudos em homenagem ao professor Carlos Alberto Dabus Maluf. São Paulo: Saraiva, 2013, p. 194.

${ }^{118}$ Código Civil Argentino. Disponível em: www.CodigoCivilOnline.com.ar. Acesso em 23 out. 2014.
} 
exceto o previsto neste Código para o matrimônio à distancia. $\mathrm{O}$ ato que carece deste requisito não produz efeitos civis. ${ }^{119}$

Portanto, podemos concluir que a Teoria da Inexistência, com relação ao casamento restou modificada na Argentina, com a previsão legal do casamento entre duas pessoas do mesmo sexo, permanecendo somente os requisitos do consentimento de ambos os contraentes e a celebração ante a autoridade competente para celebrá-lo para que o casamento seja considerado existente.

\subsubsection{Dinamarca}

Ensina o professor Álvaro Villaça Azevedo que na Dinamarca, desde 1984, as uniões homossexuais vêm sendo estudadas por comissões, e, a partir de 1986, foram concedidos alguns direitos patrimoniais às uniões civis homossexuais, que foram legalizadas em 1989.

A Lei n. 372, de $1^{\circ}$ de junho de 1989 , da parceria homossexual registrada, a qual teve início de vigência em $1^{\circ}$ de outubro do mesmo ano, foi de iniciativa do Parlamento dinamarquês, que colocou a Dinamarca como primeiro país a adotar essa espécie de legislação.

Quanto aos efeitos legais desse registro, a parceria registrada deve produzir os mesmos efeitos legais que o contrato de casamento, devendo ser aplicadas aos parceiros as mesmas disposições que são aplicadas aos esposos, com exceção da Lei de Adoção e Lei de Incapacidade e Guarda.

A Lei sobre Formação e Dissolução do Casamento, a Lei de Herança, o Código Penal e a Lei de Tributos Hereditários foram emendadas, a fim de incluir a parceria registrada, pela Lei $\mathrm{n}^{\circ} 372$, de $1^{\circ}$ de junho de 1989 , com início de vigência em $1^{\circ}$ de outubro de $1989 .{ }^{120}$

\footnotetext{
119 Nuevo Codigo Civil y Comercial de la Nacion Argentina. Disponível em: http://www.nuevocodigocivil.com/pdf/Texto-del-Proyecto-de-Codigo-Civil-y-Comercial-de-la-Nacion.pdf Acesso em 23 out. 2014.

${ }^{120}$ AZEVEDO, Álvaro Villaça. União Homoafetiva. Revista Juris da FAAP, vol. 5 - jan. a jun., 2011, p. 910.
} 
Atualmente não existe mais o requisito da nacionalidade dinamarquesa para que os conviventes possam levar a cabo a sua pareceria registrada. Atualmente, o requisito se limita a que, pelo menos um deles, seja residente no país há dois anos. Além disso, noruegueses, suecos e islandeses serão tratados como se dinamarqueses fossem, pois suas leis de parceria registrada são similares à dinamarquesa.

Como já mencionado acima, relativamente à parceria registrada serão conferidos efeitos de todas as legislações mencionadas. Uma das modificações com maior relevo diz respeito à proibição de contrair núpcias enquanto perdurar o casamento ou parceria anterior. Caso tal norma seja descumprida, o Código Penal prevê pena de até 3 anos de prisão. Outra mudança se refere à esfera patrimonial e veda que aquele que tenha sido casado ou membro de parceria faça novo contrato, antes do início, perante a Corte, da divisão da propriedade conjunta. Do mesmo modo, a Lei de Herança exige a partilha dos bens comuns antes que se convole novas núpcias ou se registre nova parceria. ${ }^{121}$

Quanto à adoção, em 1999 a Dinamarca permite a adoção do filho do parceiro homossexual e aprova dez anos depois, em março de 2009 a adoção de crianças por casal homossexual.

Em junho de 2012, após 23 anos da lei de parceria civil, o Parlamento da Dinamarca aprovou uma lei que permite aos homossexuais se casarem na Igreja Evangélica Luterana, igreja oficial do Estado. Porém, deixou para os pastores a opção de realizar a cerimônia ou pedir que outro assuma esta responsabilidade. A Dinamarca foi o primeiro país do mundo a permitir que casais homossexuais oficializassem uniões civis em 1989 e, mais tarde, deu aos homossexuais o direito de terem estas uniões reconhecidas pela Igreja. $^{122}$

Com a adoção da nova lei, a Dinamarca, onde não existe separação entre Estado e Igreja, se unirá aos países que já permitem o casamento entre pessoas do mesmo sexo, como Holanda, Bélgica, Espanha, Canadá, África do Sul, Noruega, Suécia, Portugal, Islândia e Argentina.

121 CHAVES, Marianna. Homoafetividade e Direito. Proteção Constitucional, Uniões, Casamento e Parentalidade. $2^{\mathrm{a}}$ ed. Curitiba: Juruá, 2012, p. 127-128.

${ }^{122}$ Dinamarca aprova lei que permite casamento gay em igrejas. Disponível em: http://noticias.terra.com.br/mundo/dinamarca-aprova-lei-que-permite-casamento-gay-... Acesso em 07 jan. 2014. 


\subsubsection{Uruguai}

O Uruguai se tornou em abril de 2013 o segundo país latino-americano a legalizar o casamento entre pessoas do mesmo sexo, depois que a Argentina o fez em 2010, e o décimo segundo do mundo. Anteriormente já havia legalizado a união civil e a adoção de crianças por casais homossexuais.

O Projeto de Lei chamado "casamento igualitário", recebeu aprovação final em 10 de abril de 2013. A Lei No 19.075 - Matrimônio Igualitário, publicada no D.O em 09 de maio de 2013, em seu artigo $1^{\circ}$ modifica o artigo 83 do Código Civil uruguaio nos seguintes termos: "O matrimônio civil é a união permanente, nos termos da lei, de duas pessoas de distinto ou igual sexo." A legislação também traz mudanças, tanto para homossexuais como para heterossexuais, sobre filiação, divórcio, idade mínima para contrair matrimônio, regime sucessório, adoção e ordem do sobrenome dos filhos. ${ }^{123}$

Em 25 de maio de 2009, o senador Percovich anunciou que, se a Frente Ampla ganhasse as eleições presidenciais daquele ano, apresentaria um projeto de lei a fim de permitir os casamentos independentemente da questão sexual. Em outubro do mesmo ano, a Frente Ampla ganhou as eleições com maioria absoluta em ambas as casas, e José Mujica, o candidato da Frente Ampla, foi eleito presidente depois de vencer o segundo turno.

Em julho de 2010, a Assembleia Legislativa anunciou um projeto de lei para permitir o casamento entre pessoas do mesmo sexo.

Em 6 de dezembro de 2012, após um ano e meio de discussão, a Comissão de Constituição e Códigos aprovou o matrimônio igualitário proposto.

Em 12 de dezembro de 2012, a lei recebeu aprovação preliminar no plenário da Câmara dos Deputados, recebendo a aprovação final em 10 de abril de $2013 .{ }^{124}$

\footnotetext{
$123 \quad$ Ley $\quad \mathrm{N}^{\mathrm{o}} \quad 19.075 / 2013 . \quad$ Matrimonio $\quad$ Igualitario. Disponível em http://www.parlamento.gub.uy/leyes/AcessoTextoLey.asp?Ley=19075\&Anchor= Acesso em 16 mai. 2015.

124 Casamento entre pessoas do mesmo sexo no Uruguai. Disponível em: http://pt.wikipedia.org/wiki/Casamento_entre_pessoas_do_mesmo_sexo_no_Uruguai . Acesso em 28 dez. 2013.
} 
O Congresso do Uruguai legalizou em 18 de dezembro de 2007 a união civil entre casais homossexuais. Foi a primeira lei nacional deste tipo aprovada em um país da América Latina. Pela nova legislação, casais homossexuais e heterossexuais poderão formar uniões civis após viverem juntos por cinco anos. Eles terão direitos similares aos garantidos aos casados.

Várias cidades latino-americanas, como Cidade do México e Buenos Aires, já tinham leis que permitiam a união civil entre homossexuais, mas a iniciativa é a primeira de âmbito nacional. ${ }^{125}$

Assim, no final do ano de 2007, a lei foi promulgada pelo Presidente da República, Tabaré Vasquez e entrou em vigor na primeira semana de 2008, e passou a regular os direitos e obrigações daqueles que estivessem juntos, ininterruptamente, por mais de 5 anos, sejam homo ou heterossexuais. A lei trata do regime de bens, direitos sucessórios, direito a pensão por falecimento e outras disposições previdenciárias. ${ }^{126}$

Em 9 de setembro de 2009, o Senado uruguaio aprovou projeto de lei tornando o Uruguai o primeiro país da América Latina a aprovar a adoção homoparental em nível nacional, três meses antes da Cidade do México. O projeto é uma reforma do Código da Infância e da Adolescência que não especifica direitos de homossexuais, mas permite a lei o direito da criança a uma família e está acessível a casais constituídos por meio de uniões civis- acessíveis aos casais de mesmo sexo desde 2007. O projeto seguiu para promulgação pelo então presidente Tabaré Vázquez. ${ }^{127}$

\subsubsection{Nova Zelândia}

A Nova Zelândia tornou-se o primeiro país da Oceania e o décimo-terceiro a permitir que casais do mesmo sexo se casem em 19 de agosto de 2013.

\footnotetext{
${ }^{125}$ Uruguai aprova união civil entre gays. Disponível em: http://g1.globo.com/Noticias/Mundo/0,,MUL232721-5602,00-URUGUAI+APROVA... Acesso em 11 jan. 2014.

${ }^{126}$ CHAVES, Mariana. Homoafetividade e Direito. Proteção Constitucional, Uniões, Casamento e Parentalidade. 2. ed. Curutiba: Juruá, 2012, p.158.

127 Adoção homoparental. Disponível em: http://pt.wikipedia.org/wiki/Ad\%C3\%A7\%C3\%A3o_homoparental. Acesso em 10 jan. 2014.
} 
O projeto de lei para a legalização foi aprovado pela Câmara dos Deputados em 17 de abril de 2013, com 77 votos a favor e 44 contra. O projeto recebeu aprovação em 19 de abril de 2013. A medida entrou em vigor quatro meses após a aprovação, em 19 de agosto de 2013, a fim de que houvesse tempo para que o Ministério da Administração Interna fizesse as mudanças necessárias para o licenciamento de casamento e a documentação relacionada. ${ }^{128}$

A legalização do casamento homossexual ocorre pouco mais de um quarto de século depois da descriminalização da homossexualidade em 1986. As uniões civis já eram autorizadas desde 2005 .

Esta reforma defendida pelo primeiro-ministro de centro-direita John Key foi trazida por Louisa Wall, abertamente homossexual e deputada do Partido Trabalhista. Segundo ela, a lei considerava os homossexuais da Nova Zelândia como sendo inferiores aos demais cidadãos. Assim, esta nova lei permite assegurar que o Estado não discrimina ninguém em função de sua orientação sexual. ${ }^{129}$

Desde 29 de março de 2001 quatro propostas de lei, significativamente importantes para os casais homossexuais, foram aprovadas pelo Parlamento entrando em vigor a partir de $1^{\circ}$ de fevereiro de 2002 . A primeira lei determinou que casais do mesmo sexo e casais heterossexuais, unidos de fato, cujo relacionamento houvesse durado pelo menos três anos antes da dissolução estarão sujeitos ao mesmo regime de direitos de propriedade e obrigações que os casais unidos pelo matrimônio quando da dissolução do relacionamento. A segunda lei concedeu aos parceiros do mesmo sexo o mesmo direito sucessório que os cônjuges, quando não houver testamento. A terceira lei outorgou aos companheiros homossexuais o direito legal e legitimidade para fazer uma reclamação contra a herança do parceiro falecido. A quarta lei prevê a prestação de alimentos quando acabar o relacionamento. ${ }^{130}$

\footnotetext{
128 Casamento entre pessoas do mesmo sexo na Nova Zelândia. Disponível em: http://pt.wikipedia.org/wiki/Casamento_entre_pessoas_do_mesmo_sexo_na_Nova_Z... Acesso em 28 dez. 2013.

${ }^{129}$ La Nouvelle-Zélande légalise le mariage homosexuel. Disponível em: http://www.lemonde.fr/asiepacifique/article/2013/04/17-nouvelle-zelande-legalise- Acesso em 17 abr. 2013.

130 CHAVES, Marianna. Homoafetividade e Direito. Proteção Constitucional, Uniões, Casamento e Parentalidade. 2. ed. Curitiba: Juruá, 2012, p. 152.
} 


\subsubsection{França}

A Lei $n^{\circ} 404 / 2013$, que autoriza o casamento entre pessoas do mesmo sexo e a adoção, na França, aprovada pelo Conselho Constitucional francês, foi promulgada em 18 de maio de 2013, pelo presidente socialista François Hollande. O Conselho Constitucional francês é responsável por analisar se as leis criadas no país obedecem à Constituição. A França foi o décimo quarto país no mundo a permitir que casais do mesmo sexo possam se casar.

A lei havia sido aprovada pela Câmara Legislativa no final de abril, após meses de debates. Porém, a oposição conservadora ainda lutava pela revogação da lei, que também legaliza a adoção de filhos por casais homossexuais, ação que foi impedida com a aprovação do conselho.

O projeto de lei que concede aos casais do mesmo sexo o direito de se casarem e adotar crianças foi apresentado em conjunto à Assembleia Nacional Francesa pelo governo socialista do primeiro-ministro Jean-Mar Ayrault, em 7 de novembro de 2012, com o apoio do presidente François Hollande, que declarou sua intenção de apoiar a legislação durante sua campanha para a presidência. ${ }^{131}$

Inicialmente, na França, os homossexuais podiam estabelecer apenas união civil, chamado de Pacs (Pacte Civil de Solidarité) na sigla em francês que também era acessível aos heterossexuais. Por conta disso, não tinham acesso a alguns direitos, que eram reservados ao casamento, tais como a adoção, modificação do estado civil, continuando ainda solteiros, dentre outros.

Assim, no ano de 1999, por meio de alteração do Código Civil, entrou em vigor no território francês a Lei n. 99-944, de 15 de novembro, que dispõe acerca do Pacte Civil de Solidarité (Pacs), a qual autoriza que dois indivíduos, maiores de idade, do mesmo ou de distinto sexo, celebrem um contrato para organizarem suas vidas.

131 Casamento entre pessoas do mesmo sexo na França. Disponível em: http://pt.wikipedia.org/wiki/Casamento_entre_pessoas_do_mesmo_sexo_na_Fran\%C... Acesso em $28 \mathrm{dez}$. 2013. 
Note-se que o Pacs constitui um substituto precário ao casamento. A doutrina jamais ofereceu uma única razão legal para que o matrimônio e os direitos e obrigações que o acompanham, não pudesse ser acessado aos pares do mesmo sexo. ${ }^{132}$

Em 16 de novembro de 2010, a Corte de Cassação submeteu ao Conselho Constitucional sobre a constitucionalidade ou não dos artigos 75 e 144 do Código Civil. Em 28 de janeiro de 2011, o Conselho Constitucional considerou que os artigos 75 e 144 do Código Civil, que exprimem uma concepção exclusivamente heterossexual do casamento, não são inconstitucionais. De acordo com esta decisão, coube ao legislador decidir a conveniência de abrir ou não o casamento a todos os pares sem discriminação de orientação sexual. Esta questão passou, assim, ao domínio político e não jurídico. Duas propostas de lei, visando à abertura do casamento aos pares homossexuais, foram propostas à Assembleia Nacional em 2008 e 2010. Quando da eleição presidencial em 2012, vários candidatos se declararam favoráveis ao casamento homossexual. Em 2 de fevereiro de 2013, a Assembleia Nacional acatou o primeiro artigo da proposta de lei, conhecida como "mariage pour tous" (casamento para todos), com 249 votos a favor e 97 contra, permitindo assim, o casamento entre pessoas do mesmo sexo. A lei assegurou também a possibilidade de adoção para os casais do mesmo sexo, em 12 de fevereiro com 329 votos a favor e 229 votos contra e 10 abstenções. A lei é definitivamente votada pela Assembleia Nacional em 23 de abril de 2013. A promulgação pelo presidente da República é suspensa, devido a um recurso sobre a constitucionalidade ou não da lei, que entendeu constitucional em 17 de maio de 2013, tendo em vista a luta mundial contra a homofobia. A promulgação da Lei $n^{\circ}$ 404/2013 é feita no dia seguinte, 18 de maio de 2013, tornando o casamento entre pessoas do mesmo sexo legal na França. ${ }^{133}$

Um dos pontos mais polêmicos do texto legislativo diz respeito à adoção. A partir de agora, uma criança adotada por apenas uma pessoa poderá ser adotada uma segunda vez pelo cônjuge dessa pessoa, independentemente do sexo. O texto deixa bem claro que "o casamento e a filiação adotiva implicam os mesmos efeitos, direitos e obrigações reconhecidos pelas leis (...) caso os esposos ou pais sejam de sexos diferentes ou de mesmo sexo". Os termos marido e mulher foram substituídos por esposos e os termos pai e mãe por pais.

132 CHAVES, Marianna. Homoafetividade e Direito. Proteção Constitucional, Uniões, Casamento e Parentalidade. 2 ed. Curitiba: Juruá, 2012, p. 144-145.

${ }^{133}$ Mariage homosexuel. Disponível em: http://fr.wikipedia.org/wiki/Mariage homosexuel . Acesso em 09 jan. 2014. 
A lei não menciona a reprodução assistida, e a gestação de substituição. Esse tema deverá ser regulamentado em um futuro projeto de lei. ${ }^{134}$

Recentemente, em 03 de fevereiro de 2014, o Governo francês anunciou que não apoiará a legalização da reprodução medicamente assistida e tampouco a gestação de substituição aos casais homossexuais, um dia depois das manifestações em Paris e Lyon de milhares de pessoas em defesa do modelo tradicional de família.

O presidente François Hollande, que sempre se mostrou contrário à legalização da gestação de substituição, havia se comprometido, durante a campanha eleitoral, a aprovar a reprodução assistida para os casais de lésbicas. A reprodução assistida deveria ser regulamentada em um novo projeto de lei. Esse direito já existe em países vizinhos como Espanha e Bélgica.

A mudança de postura do Executivo provocou surpresa nos grupos defensores dos direitos dos homossexuais, que protestaram dizendo que muitas lésbicas serão obrigadas a fazerem tais procedimentos em outros países como Bélgica e Espanha, como se fossem clandestinas. 135

Da leitura da Lei n 404/2013 verificam-se as seguintes modificações no Código Civil francês. Com relação ao casamento: Art. 143. "O casamento é contraído por duas pessoas de sexos diferentes ou de mesmo sexo.”. Com relação à filiação adotiva, foi inserta uma alínea ao Art. 360 do Código Civil francês, assim redigida: "A criança precedentemente adotada por um só pessoa, na forma simples ou plena, pode ser adotada um segunda vez pelo outro cônjuge na forma simples." Os termos marido e mulher são substituídos por esposos e os termos pai e mãe por pais. A lei não menciona a reprodução medicamente assistida, que inclui as práticas de fertilização "in vitro" e a gestação de substituição. $^{136}$

\footnotetext{
134 França aprova casamento e adoção para homossexuais. Disponível em: http://www.portugues.rfi.fr/franca/20130423-deputados-franceses-adotam-casamento-... Acesso em 09 fev. 2014.

135 Governo da França fecha a porta para reprodução assistida para lésbicas. Disponível em: http://noticias.r7.com/internacional/governo-da-franca-fecha-a-porta-para-reproducao-... Acesso em 06 jan. 2014.

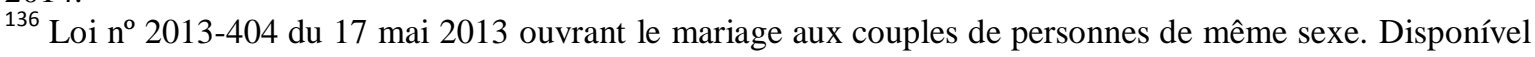
em: http://www.legifrance.gouv.fr/affichTexteArticle.do;jsessionid=CD70A5748E4A7484... Code Civil. Version Consolidée du Code au 22 décembre 2014. Edition: 2014-12-28. Disponível em: http://codes.droit.org/cod/civil.pdf. Acesso em 09 jan. 2014.
} 
Em abril de 2015, O Tribunal de Justiça do Rio de Janeiro publicou a notícia de que, por meio da adoção internacional, dois franceses Descharles Olivier, 35 anos e Mathieu Guillaume, 32 anos, que são casados, adotaram três irmãos brasileiros Willian (10), Rodrigo (8) e Kauã (7). O casal é da minúscula cidade francesa de Cerisé, com pouco mais de 700 habitantes. A decisão de adotar sempre esteve presente na vida dos professores de escola primária. O contato com alunos e sobrinhos despertou nos dois o sonho de formar uma nova família. "Somos uma família como qualquer outra. Damos amor, carinho e cuidado. Em que isso difere de um pai e uma mãe?", questiona Mathieu, que afirma ter sido muito elogiado no Brasil por resolver adotar as três crianças. Preconceito? Descharles e Mathieu não escondem que existe. Mas, e daí? ${ }^{137}$

De tudo o que foi visto podemos chegar a algumas conclusões.

Vê-se que, também na França, a resistência com relação ao casamento entre casais homossexuais teve de ser vencida, a partir dos anos 90, inicialmente com reiteradas demandas judiciais.

Como uma solução inicial, não somente para os casais homossexuais, mas para aquelas pessoas que por meio de um contrato formal desejavam organizar suas vidas, no ano de 1999, mediante alteração do Código Civil entrou em vigor em 15 de novembro a Lei no 99-944 que dispõe sobre o "Pacte Civil de Solidarité" (Pacs). No entanto, o Pacs mostrou-se bastante diferente do casamento e não atendia os anseios dos homossexuais que pretendiam a adoção de filhos em conjunto, a modificação do estado civil e o reconhecimento e respeito pelos demais membros da sociedade, que são inerentes ao casamento. Os pares homossexuais tentavam converter o Pacs em casamento por meio da tese de inconstitucionalidade dos artigos do Código 75 e 144 que disciplinando o instituto do casamento se referiam apenas a "marido e mulher" e "homem e mulher", mas não obtiveram sucesso. A Corte Constitucional francesa entendeu pela constitucionalidade dos artigos 75 e 144 e que a decisão não cabia ao Poder Judiciário, mas ao Poder Legislativo.

Assim, tornando-se uma decisão política, vários candidatos abraçaram a causa e se declararam favoráveis ao casamento homossexual e à adoção por casais homossexuais. O Presidente eleito François Hollande era favorável ao "mariage pour tous" (casamento

\footnotetext{
137 Adoção e doação: casal homossexual francês adota três irmãos. Disponível em: http://tjrj.jus.br/web/guest/home/-/noticias/visualizar/10011?p_p_state=maximiz... Acesso em 03 abr. 2015.
} 
para todos), embora houvesse manifestações contrárias de grupos conservadores que engrossavam os protestos de "manif pour tous" (manifestação para todos).

Assim, a França em 18 de maio de 2013 foi o $14^{\circ}$ país a tornar legal o casamento entre pessoas do mesmo sexo após a Corte Constitucional entender que a Lei nº 404/2013, que modificava vários artigos do Código Civil era constitucional.

Vê-se que o reconhecimento do casamento para os pares homossexuais foi conseguido por via do Poder Legislativo com o apoio do Poder Executivo. O Poder Judiciário, ao final, apenas ratificou o que decidiram os dois poderes. Um dos motivos talvez seja porque o casamento não está previsto na Constituição francesa, mas numa lei, ou seja, o Código Civil francês.

Com relação ao reconhecimento da reprodução medicamente assistida e a gestação de substituição para os casais homossexuais parece que seguirá o mesmo caminho trilhado pelo casamento homossexual, isto é, dependerá dos poderes Executivo e Legislativo num primeiro momento.

\subsubsection{Reino Unido}

O casamento entre pessoas do mesmo sexo foi legalizado em julho de 2013 no País de Gales e na Inglaterra, que se tornaram respectivamente o décimo quinto e décimo sexto países a legalizarem o casamento homossexual. A lei permite a realização de cerimônias civil e religiosa, mas não obriga as organizações religiosas a realizar cerimônias de casamento entre pessoas do mesmo sexo. Nos dois países, a união civil entre casais homossexuais já era permitida desde 2004 com o advento da Civil Partnership Act 2004.

Um dia após o texto ser aprovado no Parlamento britânico, a rainha Elizabeth II deu consentimento para que a lei entrasse em vigor nos dois países. Mesmo com a decisão, as primeiras cerimônias só poderão ser realizadas a partir de março de 2014, tendo em vista que o governo precisa resolver algumas questões administrativas, como o efeito da lei sobre o pagamento de pensões. 
Após o consentimento da rainha, a ministra da Cultura, Maria Miller, cuja pasta elaborou o texto afirmou que "é um momento histórico, que repercutirá na vida de muitas pessoas”. A lei também teve o apoio do primeiro-ministro David Cameron, mas provocou divisões no Partido Conservador. Instituições religiosas também criticaram o debate em torno do tema. Os partidos Trabalhista e Liberal Democrata apoiaram o projeto. ${ }^{138}$

Quanto à adoção homoparental, desde 30 de dezembro de 2005, qualquer casal casado ou não, do mesmo sexo ou de sexos diferentes, pode se candidatar à adoção conjunta e deverá demonstrar que a sua união é uma relação sólida de família. Esta lei faz parte do Adoption and Children Act, um diploma de proteção da adoção e da criança que, aprovada em novembro de 2002 na Inglaterra e no País de Gales entrou em vigor no dia 30 de dezembro de 2005.

São permitidas as adoções conjunta e a coadoção por um dos parceiros ou cônjuge de um casal de pessoas do mesmo sexo do filho biológico ou adotivo do outro cônjuge ou parceiro. $^{139}$

Depois de Gales e Inglaterra, a Escócia se soma à lista de territórios do Reino Unido a aprovarem o casamento entre pessoas do mesmo sexo. A lei foi aprovada em 04 de fevereiro de 2014 por 105 votos contra 18, apesar da oposição de suas principais organizações religiosas. Tornou-se o décimo sétimo país a legalizar o casamento entre pessoas do mesmo sexo.

A iniciativa teve a oposição da Igreja Católica Escocesa e a Igreja Presbiteriana da Escócia, mas a lei não vai compelir instituições religiosas a realizar cerimônias em suas instalações.

A legislação é semelhante à aprovada pelo Parlamento da Grã-Bretanha que permite casamentos homossexuais na Inglaterra e no País de Gales.

Defensores dos homossexuais disseram que a votação foi um marco para a igualdade de lésbicas, gays, bissexuais e transgêneros na Escócia e elogiaram os esforços

\footnotetext{
${ }^{138}$ Rainha Elizabeth II oficializa lei do Casamento Gay. Disponível em: http://veja.abril.com.br/noticia/internacional/rainha-oficializa-a-lei-do-casamento-gay-... Acesso em 04 jan. 2014.

${ }^{139}$ Adoção Homoparental. Hisponível em: http://pt.wikipedia.org/wiki/Ado\%C3\%A7\%C3\%A3o_homoparental Acesso em 10 jan. 2014.
} 
do governo escocês para fazer avançar a aprovação. Atualmente, a lei escocesa permite que casais do mesmo sexo estabeleçam uma parceria civil.

Ser homossexual na Escócia era um crime até 1980.

Assim, depois de Gales e Inglaterra, a Escócia se soma à lista de territórios do Reino Unido a aprovarem o casamento entre pessoas do mesmo sexo. ${ }^{140}$

Quanto à adoção conjunta para casais homossexuais, a partir de outubro de 2009, entrou em vigor na Escócia lei que permite aos casais homossexuais adotarem conjuntamente. Tal possibilidade seguia vetada no país, pois os homossexuais só podiam adotar individualmente. Com a nova lei a Escócia se junta à Inglaterra e ao País de Gales, onde a adoção conjunta já é possível desde 2005. Dos quatro territórios que integram o Reino Unido, apenas a Irlanda do Norte não permite o casamento de casais do mesmo sexo. $^{141}$

\subsubsection{Luxemburgo}

Os parlamentares de Luxemburgo, cujo primeiro-ministro Xavier Bettel é abertamente homossexual, aprovaram em 18 de junho de 2014 o projeto de lei que estabelece que "duas pessoas de sexos diferentes ou do mesmo sexo podem contrair matrimônio". A aprovação teve larga maioria de 56 votos a favor contra quatro votos da oposição. O projeto de lei estipula igualmente que casais homossexuais podem adotar crianças. A lei deverá entrar em vigor em 2015.

O projeto de lei reescreve uma lei do casamento que data de 1804. A idade legal para o casamento foi fixada em 18 anos.

Assim, Luxemburgo tornou-se o $11^{\circ}$ país da Europa a conceder o casamento a todos, juntando-se à Holanda, Bélgica, Espanha, Noruega, Suécia, Portugal, Islândia, Dinamarca, França e Reino Unido (Inglaterra, País de Gales e Escócia).

140 Escócia é o $17^{\circ}$ país a aprovar casamento entre homossexuais. Disponível em: http://br.reuters.com/articlePrint?article=BRSPES1308520140204 Acesso em 06 fev. 2014.

${ }_{141}$ Escócia aprova adoção conjunta para casais homossexuais. Disponível em: http://ibdfam.jusbrasil.com.br/noticias/1932779/escocia-aprova-adocao-conjunta-para... Acesso em 19 abr. 2015. 
Em 2004, Luxemburgo já havia reconhecido o direito à união civil de casais do mesmo sexo. Em 2010, o casamento homossexual surgia no programa do então primeiroministro do Partido Popular Social-Cristão, Jean-Claude Juncker. Por falta de consenso entre os deputados, só durante o Governo do primeiro-ministro Xavier Bettel, por meio de uma coligação entre os socialistas e os verdes, Luxemburgo teve o casamento entre pessoas do mesmo sexo aprovado. ${ }^{142}$

Em 15 de maio de 2015, o primeiro-ministro Xavier Bettel se casou com o arquiteto belga Gauthier Destenay, tornando-se o primeiro líder da União Europeia (UE) a se unir legalmente com uma pessoa do mesmo sexo. Os dois já viviam desde 2010 em união civil. Em 2010, a primeira-ministra da Islândia Johanna Siguròardóttir se casou com sua companheira, porém a ilha não faz parte da União Europeia (UE).

O primeiro-ministro de Luxemburgo, Xavier Bettel justificou-se:

"Poderia esconder ou reprimir minha homossexualidade, mas seria infeliz por toda minha vida. Poderia ter relacionamento com alguém de outro sexo, mantendo em segredo minha relação homossexual. Mas, penso que se você é um político honesto, deve ser honesto consigo mesmo e aceitar aquilo que você é".

\subsubsection{Irlanda}

A Irlanda tornou-se o primeiro país do mundo a aprovar o casamento entre pessoas do mesmo sexo por meio de um referendo popular em 23 de maio de 2015 . No referendo realizado em 22 de maio, $62 \%$ dos votos foram a favor do matrimônio entre homossexuais e $38 \%$ foram contrários. Assim a Irlanda torna-se o décimo nono país a permitir o casamento entre pessoas do mesmo sexo.

Em um país em que $85 \%$ da população é católica, a Igreja se opôs à mudança na campanha do referendo, com apoio de políticos conservadores. A votação aconteceu vinte e dois anos depois de o país descriminalizar a relação entre homossexuais.

\footnotetext{
142 Luxemburgo aprova casamento e adoção homossexuais. Disponível em: http://www.dn.pt/inicio/globo/interior.aspx?content_id=3981199\&seccao=Europa Acesso em 16 mai. 2015. 143 Il premier del Lussemburgo ha sposato il suo compagno. Disponível em : http://www.lastampa.it/2015/05/16/esteri/il-premier-del-lussemburgo-ha-sposato-il-su... Acesso em 17 mai. 2015.
} 
No referendo, os irlandeses ratificaram mudança na Constituição aprovada pelo Parlamento em março. A partir de agora, a lei maior permitirá a celebração do matrimônio entre duas pessoas "sem distinção de sexo".

A Irlanda permite a união civil entre pessoas do mesmo sexo desde 2010. Segundo especialistas irlandeses os casais homossexuais terão a proteção da união civil e estarão também amparados como uma família com os mesmos direitos de um casal heterossexual. ${ }^{144}$

\subsubsection{Estados Unidos}

Em 1996, o então Presidente Bill Clinton promulga a Lei de Defesa do Casamento (Desfense of Marriage Act ou DOMA) que define, para fins federais, que um casamento só é válido entre um homem e uma mulher.

Em 26 de junho de 2013, a Suprema Corte dos Estados Unidos, em uma decisão histórica, revogou uma parte importante da Lei de Defesa do Casamento (DOMA), que negava aos homossexuais legalmente casados os mesmos benefícios federais concedidos aos casais heterossexuais.

Por cinco votos a quatro, os nove magistrados permitiram que casais homossexuais passassem a ter acesso a centenas de provisões e benefícios federais como, por exemplo, seguridade social e imposto de renda os quais, antes, eram reservados exclusivamente aos casais heterossexuais.

O trecho da chamada Lei de Defesa do Casamento (DOMA, na sigla em inglês) que define matrimônio como "união entre um homem e uma mulher" foi contestado judicialmente por uma mulher de Nova Iorque, Edith Windsor, 84 anos, que se casou com sua parceira nova-iorquina, Thea Clara Spyer no Canadá em 2007, após 40 anos de relacionamento.

\footnotetext{
144 Irlanda aprova casamento gay em votação. Disponível em: http://www1.folha.uol.com.br/fsp/mundo/220339-irlanda-aprova-casamento-gay-em-votacao.shtml. Acesso em 24 mai. 2015.
} 
Spyer morreu em 2009. Mas, para receber a herança, Windsor teria de pagar cerca de US\$ 360 mil (R $\$ 790$ mil) em impostos que, normalmente, não seriam aplicados a um cônjuge herdeiro heterossexual.

Analisando o caso, os juízes entenderam que essa discriminação é inconstitucional e equivale a uma "privação de liberdade", o que contraria a $5^{\mathrm{a}}$ emenda da Constituição americana.

Até junho de 2013, doze Estados e o Distrito de Columbia permitiam o casamento homossexual. Porém, a legislação barrava os benefícios federais mesmo para cônjuges como Spyer e Windsor, que viviam em Nova Iorque, um Estado que reconhece esses matrimônios.

Porém, ao julgar a Lei de Defesa do Casamento, a Suprema Corte não avaliou, por exemplo, outra parte da lei que desobriga os Estados a reconhecer as uniões homossexuais realizadas nas jurisdições onde elas são legais. Isto é, um casal homossexual oriundo do Texas, que se case em Nova Iorque não terá seu matrimônio validado em seu Estado de origem, onde tal tipo de enlace ainda é proibido.

Assim, nos demais Estados americanos onde não era reconhecido o casamento homossexual, não existia nenhuma proteção legal para indivíduos LGBT, que continuavam sujeitos, por exemplo, a serem demitidos de seus empregos, ou serem rejeitados como inquilinos por causa de sua orientação sexual.

Portanto, casais homossexuais poderiam se abster de pedir os benefícios federais se isso implicasse, por exemplo, revelar o seu estado civil para empregadores e serem demitidos por serem homossexuais. ${ }^{145}$

Após a decisão da Suprema Corte dos Estados Unidos, em junho de 2013, a qual permitiu aos homossexuais legalmente casados os mesmo benefícios federais concedidos aos casais heterossexuais, vários Estados, por meio do Poder Judiciário, conseguiram anular as leis que proibiam as uniões entre pessoas do mesmo sexo.

Até maio de 2015, além do Distrito de Columbia (2010), onde fica a capital Washington, outros 37 Estados permitiamm o casamento entre homossexuais, 26 por

145 Apesar de vitória no Supremo, gays ainda vivem em "dois EUA". Disponível em: http://g1.globo.com/mundo/noticia/2013/06/apesar-de-vitoria-no-supremo-gays-ainda... Acesso em 12 jan. 2014. 
decisão judicial, oito por lei estadual e três por voto popular. São eles: 1) Massachusetts (2004), 2) Connecticut (2008), 3) Iowa (2009), 4) Vermont (2009), 5) New Hampshire (2010), 6) Nova Iorque (2011), 7) Whashington (2012), 8) Maine (2012), 9) Maryland (2013), 10) Rhode Island (2013), 11) Delaware (2013), 12) Minnesota (2013), 13) Califórnia (2013), 14) Nova Jersey (2013), 15) Havaí (2013), 16) Illinois (2013), 17) Novo México (2013), 18) Oregon (2014), 19) Pensilvânia (2014), 20) Indiana (2014), 21) Oklahoma (2014), 22) Utah (2014), 23) Virginia (2014), 24)Wisconsin (2014), 25) Colorado (2014), 26) Nevada (2014), 27) Alasca (2014), 28) Idaho (2014), 29) West Virginia (2014), 30) Carolina do Norte (2014), 31) Arizona (2014), 32) Wyoming (2014), 33) Kansas (2014), 34) Carolina do Sul (2014), 35 ) Montana (2014), 36) Flórida (2015) e 37) Alabama (2015).

Os 13 estados restantes proibiram o casamento homossexual: 12 por emenda constitucional e lei estadual e um por emenda constitucional apenas. Portanto, dos 50 Estados, 37 admitem o casamento entre pessoas do mesmo sexo.

Os vinte e seis Estados que autorizaram o casamento homossexual por meio de decisões judiciais são: 1) Alabama, 2) Alasca, 3) Arizona, 4) Califórnia, 5) Carolina do Norte, 6) Colorado, 7) Connecticut, 8) Flórida, 9) Idaho, 10) Indiana, 11) Iowa, 12) Kansas, 13) Massachussetts, 14) Montana, 15) Nevada, 16) Nova Jersey, 17) Novo México, 18) Oklahoma, 19) Oregon, 20) Pennsylvania, 21) South Carolina, 22) Utah, 23) Virginia, 24) West Virginia, 25) Wisconsin, 26) Wyoming.

Os oito Estados que permitiram o casamento homossexual por legislação estadual são: 1) Delaware, 2) Hawaii, 3) Illinois, 4) Minnesota, 5) New Hampshire, 6) New York, 7) Rhode Island, 8) Vermont.

Os três Estados em que o casamento homossexual foi legalizado por meio de plebiscitos são: 1) Maine, 2) Maryland, 3) Washington.

Finalmente, os treze Estados que proibiam o casamento homossexual por meio de legislação são: 1) Arkansas, 2) Georgia, 3) Kentucky, 4) Louisiana, 5) Michigan, 6) Mississippi, 7) Missouri, 8) North Dakota, 9) Ohio, 10) South Dakota, 11) Tennessee, 12) Texas, 13) Nebraska. 
A lista dos estados norte-americanos que nunca proibiram o casamento inter-racial ou que estiveram entre os primeiros a abolir a proibição se assemelha muito às dos estados onde o casamento entre pessoas do mesmo sexo já é legal: Massachusetts (2004), Connecticut (2008), Iowa (2009), Vermont (2009), New Hampshire (2010), Nova Iorque (2011) e Washington (2012).

A Suprema Corte dos Estados Unidos, para unificar a posição de todo o país sobre o casamento entre pessoas do mesmo sexo, por meio de seus ministros, terá de responder a duas perguntas: 1) A $14^{\mathrm{a}}$ Emenda requer que todos os estados concedam licença de casamento entre duas pessoas do mesmo sexo? ; 2) A $14^{\text {a }}$ Emenda requer que um estado reconheça o casamento entre duas pessoas do mesmo sexo, quando o casamento foi legalmente licenciado em outro estado?

A $14^{\mathrm{a}}$ emenda é a que garante a todos os cidadãos direitos iguais perante a lei, entre outras garantias individuais. A garantia de direitos iguais a todos os cidadãos foi criada, por meio dessa emenda, para finalizar o processo de libertação dos escravos, logo depois da Guerra Civil. ${ }^{146}$

Em 26 de junho de 2015, a Suprema Corte dos Estados Unidos aprovou, por 5 votos a 4, o casamento entre pessoas do mesmo sexo em todos os 50 Estados do país, sendo um direito garantido pela Constituição. A decisão não terá efeito imediato, pois o tribunal permite um prazo de três semanas para pedidos de reconsideração.

O julgamento da ação conhecida como Obergefell vs. Hodges, que envolvia trinta e uma pessoas contra os Estados de Kentucky, Michigan, Ohio e Tennessee, obrigará os treze Estados americanos que ainda não tinham reconhecido legalmente o casamento entre pessoas do mesmo sexo a reconhecê-lo. Os treze Estados são: Dakota do Norte, Dakota do Sul, Nebraska, Missouri, Arkansas, Texas, Lousiana, Mississippi, Geóriga, Tennessee, Kentuchy, Ohio e Michigan.

Jim Obergefell do Estado de Ohio, após a morte de seu marido em 2013, continuou a lutar para figurar como viúvo de John Arthur em seu atestado de óbito. Eles haviam se casado, após 20 anos de relacionamento, em Maryland onde o casamento entre

\footnotetext{
${ }^{146}$ João Ozorio de Melo. Suprema Corte começa a debater futuro do casamento gay nos EUA. Disponível em: http://www.conjur.com.br/2015-abr-27/suprema-corte-comeca-debater-futuro-casame... Acesso em 17 mai. 2015.
} 
homossexuais já era reconhecido. Porém em Ohio o casamento realizado em Maryland não tinha validade.

O Presidente Barack Obama apoiou a causa. No Brasil, ao contrário, há uma forte rejeição pelos grupos conservadores e um apoio tímido pelos demais grupos que ficam preocupados em perder votos. A decisão da Suprema Corte dos Estados Unidos poderá ter alguns reflexos sobre nosso país, mas, de modo um pouco diferente, porque somos um país de matriz romano-germânica cujo sistema é o "civil law". Para os americanos o direito é ditado pela jurisprudência ("common law") e para os brasileiros o direito é ditado pelas leis. $^{147}$

\subsubsection{Massachusetts e Connecticut}

Massachusetts foi o primeiro Estado norte-americano a permitir os casamentos entre pessoas do mesmo sexo, que até então só eram legais na Holanda e na Bélgica, e não foi porque o parlamento local tivesse aprovado uma nova lei, mas por uma decisão do Supremo Tribunal Estadual, no caso "Hillary Goodrige e outros contra o Departamento de Saúde Pública e outros”. Os primeiros queixosos da lista eram Hillary Goodridge, de 44 anos e Julie Goodrige, de 43 anos, que viviam juntas há 13 anos com uma filha de 5 anos. Na sentença os juízes argumentaram:

"[...] A questão que se nos coloca é se, de acordo com a Constituição de
Massachusetts, o Tribunal de Justiça pode negar a proteção, benefícios e
obrigações conferidos ao casamento civil a dois indivíduos do mesmo sexo que
desejam se casar: concluímos que não pode. A Constituição de Massachusetts
afirma a dignidade e a igualdade de todos os indivíduos e proíbe que haja
cidadãos de segunda classe [...]. Estamos conscientes de que nossa decisão marca uma mudança na história de nossa lei matrimonial. Algumas pessoas de profundas convicções religiosas, morais e éticas creem que o casamento deveria ser limitado à união de um homem e uma mulher e que a conduta homossexual é imoral. Outros, com iguais convicções éticas, morais e religiosas, creem que os casais do mesmo sexo devem poder se casar e que as pessoas homossexuais deveriam ser tratadas do mesmo modo que seus próximo heterossexuais. Nenhum ponto de vista responde

${ }^{147}$ Decisão da Suprema Corte dos EUA sobre o reconhecimento do casamento homossexual em todo o país. Disponível em: http://edition.cnn.com/2015/06/26/politics/scotus-opinion-document-obergefellhodges/index.html. Acesso em 04 jul. 2015. 
à questão que nos é colocada. Nossa obrigação é definir a liberdade de todos, não aplicar nosso próprio código moral." 148

A decisão se seguiu a um processo apresentado em 2001 por sete casais de homossexuais contra o Departamento de Saúde Pública de Massachusetts, que negou seus pedidos de licenças de casamento.

Rejeitando a alegação do Estado de que o propósito inicial do casamento é a procriação, a corte decidiu naquela ocasião que "a condição sine qua non do casamento é o compromisso exclusivo e permanente dos cônjuges um com o outro e não gerar filhos".

"O matrimônio é uma instituição social vital", escreveu na sentença a presidente da Suprema Corte, Margaret H. Marshall.

O Tribunal declarou que não encontrou "uma razão constitucional adequada para negar o matrimônio aos casais de mesmo sexo" e que sua decisão "não altera o valor fundamental do matrimônio na nossa sociedade".

Esses casais do mesmo sexo desejam aceitar as solenes obrigações matrimoniais de exclusividade, apoio mútuo, afirmou.

"O compromisso com o outro é um testamento da perdurabilidade do lugar do matrimônio em nossas leis e no espírito humano", disse.

Em novembro de 2003, quando a decisão foi tomada, o presidente dos Estados Unidos, George W. Bush condenou a decisão da Suprema Corte de Massachusetts e anunciou que faria todo o possível para fazer respeitar o "caráter sagrado" desta instituição (o casamento, que é uma instituição sagrada entre um homem e uma mulher).

Desde a legalização do casamento entre pessoas do mesmo sexo em Massachusetts, após a decisão da Suprema Corte de 2003, seus opositores, entre os quais o governador republicano Mitt Romney, não pararam de tentar proibi-lo e pedem ao Congresso do Estado que organize um referendo popular.

Como o Legislativo tem sido reticente, os opositores ao casamento homossexual recorreram à Justiça.

\footnotetext{
${ }^{148}$ Hillary GOODRIGE \& others vs. DEPARTMENT OF PUBLIC HEALTH \& another, SJC-08860. Disponível em: http://news.findlaw.com/cnm/docs/conlaw/goodrige111803opn.pdf. Acesso em 04 jan. 2014.
} 
Na decisão divulgada em dezembro de 2006, a Suprema Corte de Massachusetts julgou que não pode obrigar os legisladores a estudarem uma proposta para proibir o casamento homossexual. A decisão, adotada unanimemente pelos juízes, significou uma nova derrota para aqueles que defendem o casamento exclusivamente heterossexual. ${ }^{149}$

Na decisão Goodridge v. Dept. of Public Health, proferida em 18 de novembro de 2003 pela Suprema Corte do Estado de Massachusetts, foi deliberado que a proibição de casamento do mesmo sexo violava a Constituição Estadual. Assim, a Corte decidiu que as licenças para casamentos civis deveriam ser disponibilizadas aos casais do mesmo sexo, sendo outorgado o prazo de 180 dias para que o legislativo de Massachusetts alterasse as leis existentes sobre casamento, de forma a torna-las neutras em relação ao gênero. Portanto, a decisão passou a ter efeito no dia 27 de maio de 2004.

A licença de casamento é concedida no Estado se ambos os candidatos tiverem a idade igual ou superior a 18 anos, não possuírem casamento anterior não dissolvido, não possuir vínculo sanguíneo com o seu par e se submeter a um exame de sangue, para comprovar a inexistência de sífilis transmissível e residência comprovada em Massachusetts.

Estando casados, o par adquire todos os direitos e responsabilidades garantidos às pessoas casadas no Estado, porém, como o Governo Federal se recusa a reconhecer os casamentos entre pessoas do mesmo sexo, os benefícios federais do casamento continuam indisponíveis. $^{150}$

Conforme visto no início deste capítulo, com a decisão da Suprema Corte dos Estados Unidos sobre a Lei de Defesa do Casamento (DOMA), já é permitido aos casais homossexuais os mesmos benefícios federais dos casamentos heterossexuais.

Em 10 de outubro de 2008, o Supremo Tribunal de Connecticut, nos Estados Unidos decidiu pela legalização do casamento homossexual e tornou-se o segundo Estado a permitir o casamento entre pessoas do mesmo sexo. A decisão foi apoiada por quatro dos sete juízes e deu razão a oito casais da cidade de Madison que processaram o Estado em 2004, tendo em vista que as autoridades locais lhes negaram permissão para se casar.

\footnotetext{
149 Opositores do casamento gay em Massachusetts são derrotados. 27 jan. 2006. Disponível em: http://www1.folha.uol.com.br/folha/mundo/ult94u103192.shtml. Acesso em 04 jan. 2014.

150 CHAVES, Marianna. Homoafetividade e Direito. Proteção Constitucional, Uniões, Casamento e Parentalidade. 2a ed. Curitiba: Juruá, 2012, p.137-138.
} 
Desde 2005, Connecticut contava com uma lei de união civil que reconhecia quase todos os direitos do casamento. Porém, os juízes consideraram que mesmo existindo um sistema de proteção legal diferenciado para gays e lésbicas, "o tratamento diferente para casais do mesmo sexo é constitucionalmente deficiente", pois significaria aplicar "uma série de princípios constitucionais para os homossexuais e outros para as demais pessoas". Em seu voto, o juiz Richard Palmer argumentou que "a interpretação da Constituição em conformidade com os princípios de igualdade conduz inexoravelmente à conclusão de que pessoas homossexuais têm o direito de se casar com quem quiserem". ${ }^{151}$

\subsubsection{Iowa e Vermont}

Iowa tornou-se o terceiro Estado dos Estados Unidos a permitir o casamento entre homossexuais. A Suprema Corte de Iowa emitiu essa decisão em 03 de abril de 2009.

A Corte do Estado norte-americano defendeu uma determinação de 2007, segundo a qual a permissão de casamento apenas entre um homem e uma mulher é uma violação à legislação estadual. "A Corte reafirmou que um estatuto inconsistente com a Constituição de Iowa deve ser declarado sem valor, mesmo que possa receber apoio de fortes crenças tradicionais e da opinião popular", consta de um resumo da decisão.

O caso de Iowa vinha se desenrolando desde 2005, quando a Lambda Legal, organização de direitos homossexuais, abriu um processo em nome de alguns casais homossexuais de Iowa a quem foram negadas licenças para casamento. ${ }^{152}$

Vermont tornou-se o quarto Estado dos Estados Unidos a permitir o casamento entre pessoas do mesmo sexo.

Vermont foi o primeiro Estado dos Estados Unidos a permitir a união civil para casais do mesmo sexo em 2000, mas só legalizou o casamento em 2009. Assim, em 26 de abril de 2000, o Parlamento do Estado de Vermont aprovou a lei sobre uniões civis, denominada de Vermont Act Relating to Civil Unions.

\footnotetext{
${ }^{151}$ BIMBI, Bruno. Casamento Igualitário. Tradução de Rosanne M. Nascimento de Souza. Rio de Janeiro: Garamond, 2013, p. 132.

${ }_{152}$ Estado de Iowa, nos EUA, autoriza casamento gay. Disponível em: http://www.estadao.com.br/noticias/internacional,estado-de-iowa-nos-eua-autoriza-casa... Acesso em 04 jan. 2014.
} 
Em 07 de abril de 2009, os parlamentares do Estado norte-americano de Vermont derrubaram um veto do governador Jim Douglas (republicano) a uma lei que permite o casamento entre pessoas do mesmo sexo. A lei passou por 100 votos a 49 na Câmara de Representantes, e por 23 a 5 no Senado Estadual.

Em $1^{\circ}$ de setembro de 2009, Vermont juntou-se, assim, a Massachusetts, Connecticut e Iowa e aprovou a House Bill 0275, permitindo o casamento entre pessoas do mesmo sexo, o que não exclui, entretanto, a figura da união civil do Estado.

Na Califórnia, o casamento homossexual foi legal entre maio e novembro de 2008, contudo a legalização foi apenas temporária. No dia em que Barack Obama foi eleito Presidente, a maioria dos californianos votou em referendo a favor da Proposta 8, uma emenda à constituição estatal que determina que apenas o casamento entre um homem e uma mulher é válido ou reconhecido. ${ }^{153}$

\subsubsection{New Hampshire e Nova Iorque}

New Hampshire é o quinto Estado norte-americano a legalizar o matrimônio entre pessoas do mesmo sexo, graças a uma lei que foi aprovada em junho de 2009 pelo Legislativo estadual e promulgada imediatamente pelo governador John Lynch. Entendemos ser o quinto, pois a Califórnia não mais reconhece o casamento homossexual.

Antes da votação, o governador anunciou que vetaria o projeto se não ficasse claro que as igrejas e os grupos religiosos não estariam obrigados a realizar os casamentos homossexuais. Assim, o projeto passou a incluir uma cláusula que indica que "cada organização, associação ou sociedade religiosa tem controle absoluto sobre sua doutrina, política, valores e crenças sobre quem deve casar dentro de sua fé". ${ }^{154}$

Em $1^{\circ}$ de janeiro de 2010, o casamento entre pessoas do mesmo sexo passou a ser permitido em New Hampshire. No entanto, a nova lei trouxe uma curiosidade que não se observou em diversos ordenamentos onde os casamentos entre pessoas do mesmo sexo

153 CHAVES, Marianna. Homoafetividade e Direito. Proteção Constitucional, Uniões, Casamento e Parentalidade. $2^{a}$ ed. Curitiba: Juruá, 2012, p.141-142; Vermont ultrapassa veto e legaliza casamento "gay". Disponível em: http://www.publico.pt/sociedade/noticia/vermont-ultrapassa-veto-e-legaliza-casamento. Acesso em 04 jan. 2014.

154 New Hampshire se torna $6^{\circ}$ Estado dos EUA a legalizar união gay. Disponível em: http://www1.folha.uol.com.br/folha/mundo/ult94u576314.shtml Acesso em 04 jan. 2014. 
foram regulamentados, isto é, a substituição de uma figura pela outra. Assim, a partir de $1^{\circ}$ de janeiro de 2010, todas as uniões civis celebradas por casais homossexuais serão convertidas automaticamente em casamentos, a exceção dos casos em que foram anuladas, dissolvidas ou previamente convertidas em casamento. ${ }^{155}$

No dia 24 de junho de 2011, por 33 a 29 votos, o Senado Estadual de Nova Iorque aprovou a legalização do casamento entre pessoas do mesmo sexo, durante votação na qual senadores democratas e republicanos explicaram seu voto.

A lei foi aprovada graças aos votos de quatro senadores republicanos conservadores. Por causa de seus votos, tiveram que enfrentar consequências nada surpreendentes para políticos com um eleitorado conservador. Em contrapartida há quem acredite que o custo político da decisão não é tão elevado quanto se imagina, pois a opinião pública com relação à homossexualidade está mudando muito rápido nos Estados Unidos.

Com a aprovação da lei, Nova Iorque converteu-se no sexto Estado dos Estados Unidos a permitir o casamento entre pessoas do mesmo sexo. As uniões civis já eram legais na cidade de Nova Iorque. ${ }^{156}$

\subsubsection{Washington, Maine e Maryland}

A governadora de Washington, Chris Gregorie, promulgou em 13 de fevereiro de 2012 a lei que legaliza o casamento homossexual no Estado, onde gays e lésbicas poderão casar-se a partir de 7 de junho de 2012. Assim, Washington será o sétimo Estado do país a permitir o casamento entre pessoas do mesmo sexo.

“Dizemos à nação que o Estado de Washington já não nega a seus cidadãos a oportunidade de casar-se com a pessoa que amam e dizemos a todas as crianças de casais do mesmo sexo que sua família é tão importante como todas as outras famílias de nosso Estado" declarou a governadora em comunicado após a aprovação parlamentar.

155 CHAVES, Marianna. Homoafetividade e Direito. Proteção Constitucional, Uniões, Casamento e Parentalidade. $2^{\mathrm{a}}$ ed. Curitiba: Juruá, 2012, p. 139.

156 Casamento gay entra em vigor em Nova York neste domingo. Disponível em: http://veja.abril.com.br/noticia/internacional/a-historia-de-quatro-senadores-conservad... Acesso em 13 jan. 2014. 
Com 55 votos a favor e 43 contra, a Câmara de Representantes de Washington aprovou a lei, que já havia sido aprovada pelo Senado Estadual em janeiro de 2012.

Os opositores à norma buscaram mecanismos legais para anular o texto antes que entrasse em vigor. O objetivo era obter mais de 120 mil apoios mediante um plebiscito para evitar que a lei entrasse em vigor. Porém, os opositores perderam e houve $52 \%$ de votos favoráveis à lei, apurados em 07 de novembro de 2012.

Neste mesmo plebiscito, em 07 de novembro de 2012, os estados americanos de Maryland, Maine e Washington aprovaram o casamento homossexual. Porém em Minesotta o resultado foi de desaprovação. ${ }^{157}$

A união entre pessoas do mesmo sexo já existia em Washington, desde 22 de julho de 2007, por meio de uma lei que o tornou o quarto Estado norte-americano a introduzir uma norma de âmbito estadual, regulando as parcerias domésticas registradas. Em 2008, o legislador alargou o âmbito de aplicação da lei, adicionando mais de 160 direitos e responsabilidades estaduais relativas ao casamento. A nova lei foi aprovada em 04 de março de 2008 e entrou em vigor em 12 de junho de $2008 .{ }^{158}$

Importante frisar que Washington, Maine e Maryland foram os primeiros Estados a legalizar o casamento homossexual por meio do voto popular.

No Maine, o casamento homossexual já havia sido autorizado em 2009, mas um referendo tornou-o ilegal. Porém, os apoiadores do casamento entre pessoas do mesmo sexo avançaram, então, com uma petição, conseguindo assinaturas suficientes para garantir um novo referendo, que resultou na legalização do casamento entre pessoas do mesmo sexo em 29 de dezembro de 2012. Assim, Maine se tornou o oitavo Estado a permitir o casamento homossexual.

No Estado de Maryland, apesar de os eleitores terem aprovado o casamento homossexual em 07 de novembro de 2012, este começou a vigorar apenas em $1^{\circ}$ de janeiro

\footnotetext{
157 Washington legaliza casamento entre pessoas do mesmo sexo. Disponível em: http://operamundi.uol.com.br/conteudo/noticias/19854/washington+legaliza+casamento...; Maryland, Maine e Washington aprovam casamento gay, dizem TVs. Disponível em: http://g1.globo.com/mundo/eleicoes-noseua/2012/noticia/2012/11/maryland-maine-e... Acesso em 13 jan. 2014.

158 CHAVES, Marianna. Homoafetividade e Direito. Proteção Constitucional, Uniões, Casamento e Parentalidade. $2^{a}$ ed. Curitiba: Juruá, 2012, p. 142-143.
} 
de 2013 e Maryland tornou-se o nono Estado a permitir o casamento entre pessoas do mesmo sexo. ${ }^{159}$

\subsubsection{Rhode Island, Delaware e Minnesota}

O pequeno Estado norte-americano de Rhode Island tornou-se em maio de 2013 o décimo Estado a permitir o casamento entre pessoas do mesmo sexo.

Centenas de pessoas aguardavam a votação do projeto de lei na Câmara dos Deputados, aprovada com 56 votos a favor e 15 contra e entrou em vigor em $1^{\circ}$ de agosto de 2013.

O governador Lincoln Chafee, antigo republicano que se tornou independente, elogiou a tolerância desse Estado do nordeste e acrescentou: "Este é um dia histórico para o nosso Estado".

Rhode Island é um Estado católico, sendo o último dos seis Estados de Nova Inglaterra (Connecticut, Maine, Massachusetts, New Hampshire, Rhode Island, Vermont) a permitir o casamento homossexual. ${ }^{160}$

O presidente Barack Obama conquistou votos em Rhode Island com o apoio ao casamento homossexual, enquanto os republicanos tentavam garantir o voto dos religiosos condenando o casamento entre pessoas do mesmo sexo. Tal problemática é comparada por alguns à briga pelos direitos civis dos negros nos anos 60 .

A primeira medida realmente impactante de Obama em favor dos homossexuais americanos foi a extinção, em 2011, da política conhecida como "Don't Ask, Don’t Tell" (Não Pergunte, Não Conte) nas forças armadas americanas, em que os homossexuais eram proibidos de servir abertamente. Assim, o exército americano passou a permitir a realização de casamentos entre pessoas do mesmo sexo pelos capelães militares. ${ }^{161}$

\footnotetext{
159 Casamento homossexual legalizado no Estado norte-americano do Maine. Disponível em: http://sicnoticias.sapo.pt/mundo/2012/12/29/casamento-homossexual-legalizado-no-es... Acesso em 04 jan. 2014.

160 Rhode Island é o $10^{\circ}$ estado a permitir casamento gay. Disponível em: http://www.dn.pt./Common/print.aspx?content_id=3197981 Acesso em 14 jan. 2014.

161 Obama conquista votos em Rhode Island com apoio ao casamento gay. Disponível em: http://noticias.terra.com.br/mundo/oriente-medio/obama-conquista-votos-em-rhode-isl... Acesso em 14 jan. 2014.
} 
Delaware se tornou em 07 de maio de 2013 o décimo primeiro Estado americano a legalizar o casamento homossexual, depois que o Congresso Estadual aprovou uma nova legislação e o governador, o democrata Jack Markell, a assinou.

O Senado do pequeno Estado do nordeste dos Estados Unidos aprovou por 12 votos a favor e nove contra a medida, que já havia sido respaldada pela Câmara dos Representantes em uma votação em abril de 2013.

Até então, Delaware permitia as uniões civis entre casais do mesmo sexo, mas não os casamentos, em uma situação similar à do Havaí, Illinois, Nova Jersey, Nevada, Oregon e Colorado.

A legalização chega menos de uma semana depois que outro pequeno Estado do nordeste, Rhode Island, aprovou o casamento homossexual.

De acordo com a lei, o casamento entre pessoas do mesmo sexo entrará em vigor a partir de $1^{\circ}$ de julho de 2013 e os casais que tenham recorrido às uniões civis poderão convertê-las em casamento se desejarem.

O casamento homossexual gera cada vez mais aceitação na sociedade americana. $^{162}$

Minnesota é o décimo segundo Estado a legalizar o casamento entre casais homossexuais.

O governador de Minnesota, Mark Dayton, ratificou em 15 de maio de 2013 uma lei que legaliza o casamento homossexual, depois de ter sido aprovada pelos representantes de Minnesota e pelo Senado.

Em duas semanas, três Estados legalizaram o casamento entre pessoas do mesmo sexo: Rhode Island, em 02 de maio, Delaware em 7 de maio e Minnesota em 15 de maio de 2013. Porém, o casamento homossexual continua a ser proibido em 38 Estados norteamericanos.

162 Delaware se torna $11^{\circ}$ Estado dos EUA a legalizar o casamento gay. Disponível em: http://noticias.terra.com.br/mundo/estados-unidos/delaware-se-torna-11-estado-dos-eu... Acesso em 04 jan. 2014. 


\subsubsection{Califórnia, Nova Jersey e Havaí}

Em 28 de junho de 2013, um tribunal de apelação em São Francisco suspendeu a proibição do casamento homossexual, em vigor há cinco anos na Califórnia. Assim, a Califórnia tornou-se o décimo terceiro Estado norte-americano a permitir o casamento entre pessoas do mesmo sexo, além do Distrito de Colúmbia.

Os casamentos entre pessoas do mesmo sexo na Califórnia haviam sido admitidos por um breve período em 2008, até o veto no referendo que aprovou a chamada Proposição 8. Essa decisão ficou em vigor até 2012, quando foi declarada inconstitucional. ${ }^{163}$

A Califórnia era o terceiro Estado dos Estados Unidos a permitir os casamentos entre homossexuais, até os eleitores californianos aprovarem a proibição do casamento homossexual em 2008.

Em fevereiro de 2004, o prefeito de São Francisco, Gavin Newsom, decidiu começar a casar os pares do mesmo sexo que o solicitavam, entendendo que a legislação que o proibia era inconstitucional. Cerca de quatro mil casais de diferentes lugares dos Estados Unidos se casaram durante as semanas seguintes naquela cidade, e a notícia percorreu o mundo. Até então, só a Holanda, a Bélgica e o estado norte-americano de Massachusetts reconheciam o direito dos casais homossexuais a casar. A decisão de Newsom gerou um longo processo judicial e político que incluiu sentenças judiciais a favor e contra, casamentos celebrados, a seguir anulados e logo declarados válidos de novo, uma lei que foi vetada pelo governador, uma decisão da Corte estadual que legalizou o casamento entre pessoas do mesmo sexo, um plebiscito que deu marcha à ré na legislação, outra decisão da Corte que manteve a validade das bodas já realizadas e novos processos que terminaram, finalmente, com uma decisão favorável da Suprema Corte de Justiça dos Estados Unidos. ${ }^{164}$

Em Nova Jersey, o casamento entre pessoas do mesmo sexo foi aprovado de forma permanente em 21 de outubro de 2013 após o governador Chris Christie desistir da

\footnotetext{
${ }^{163}$ Opositores do casamento gay pedem suspensão das uniões na Califórnia. Disponível em: http://g1.globo.com/mundo/noticia/2013/06/opositores-do-casamento-gay-pedem-suspensão-da Acesso em 14 jan. 2013.

164 BIMBI, Bruno. Casamento Igualitário. Tradução de Rosanne M. Nascimento de Souza. Rio de Janeiro: Garamond, 2013, p. 21-22.
} 
apelação contra o casamento homossexual. Assim, Nova Jersey passou a ser o décimo quarto Estado a permitir este tipo de casamento, além do Distrito de Colúmbia.

Christie vetou em 2011 uma proposta para legalizar os casamentos entre pessoas do mesmo sexo, que havia sido aprovada pelas duas câmaras legislativas do estado, porém nem a Assembleia nem o Senado conseguiram uma maioria para superar tal veto.

Uma decisão da Suprema Corte do Estado confirmou uma decisão prévia de uma corte de categoria inferior. A lei foi aprovada após a Suprema Corte derrubar parte da Lei de Defesa do Matrimônio (DOMA, na sigla em inglês), que impedia casais homossexuais de obterem os mesmos benefícios concedidos aos heterossexuais. Nova Jersey também se tornou o primeiro estado americano a mudar as próprias leis do matrimônio com base no veto imposto pelo governo federal. ${ }^{165}$

O Senado do Havaí aprovou, em 12 de novembro de 2013, com 19 votos a favor e quatro contra, a legalização dos casamentos entre pessoas do mesmo sexo. Assim, o Havaí se tornou o décimo quinto Estado americano a reconhecer os casamentos homossexuais.

A lei foi ratificada pelo governador democrata Neil Abercrombie, e após a ratificação entrou em vigor a partir de 02 de dezembro de 2013.

A norma inclui várias emendas aprovadas na Câmara dos Representantes, entre as quais as isenções para grupos e organizações religiosas que se opõem a este tipo de uniões. ${ }^{166}$

O presidente dos Estados Unidos, Barak Obama, que é havaiano, parabenizou o Estado pela decisão: "Sempre que a liberdade e a igualdade são afirmadas, o nosso país se torna mais forte". ${ }^{167}$

165 Governador de Nova Jersey desiste de apelação contra o casamento gay. Disponível em: http://veja.abril.com.br/noticia/internacional/governador-de-nova-jersey-desiste-de-ap... Acesso em 04 jan. 2014.

166 Havaí se torna $15^{\circ}$ Estado americano a aprovar casamento gay. Disponível em: http://noticias.terra.com.br/mundo/estados-unidos/havai-se-torna-15-estado-america... Acesso em 03 jan. 2014.

167 Havaí é o $16^{\circ}$ estado dos EUA a aprovar o casamento gay. Disponível em: http://veja.abril.com.br/noticia/internacional/havai-diz-aloha-ao-casamento-gay Acesso em 04 jan. 2014. 


\subsubsection{Illinois, Novo México e Oregon}

Illinois se transformou no décimo sexto Estado dos Estados Unidos a legalizar o casamento entre pessoas do mesmo sexo, depois de a lei ser sancionada, em 20 de novembro de 2013, pelo governador Pat Quinn. A lei entrou em vigor no dia $1^{\circ}$ de junho de 2014.

A batalha pelos direitos dos homossexuais em Illinois ganhou força em 2005 quando o então governador democrata, Rod Blagojevich, sancionou uma lei sobre os direitos dos homossexuais, que foi seguida por uma lei de união civil assinada em janeiro de 2011.

Sob a nova lei, a definição de casamento em Illinois mudará da união entre um homem e uma mulher para união entre duas pessoas.

As uniões civis transformaram-se em casamento em Illinois assim que a promulgação da lei completou um ano.

Assim, o casamento entre pessoas do mesmo sexo é legal em outros quinze Estados dos Estados Unidos, que o aprovaram por meio de suas Cortes Supremas ou de assembleias gerais desde 2004 até os dias de hoje. ${ }^{168}$

No Novo México, o Tribunal Superior do Estado, em 19 de dezembro de 2013 legalizou o casamento homossexual, declarando ser inconstitucional negar uma licença de casamento para casais de mesmo sexo. O Estado do Novo México é o décimo sétimo dos cinquenta do país, mais o Distrito de Colúmbia, a permitir o casamento homossexual.

O Novo México agora se junta aos 16 Estados e ao Distrito de Colúmbia na permissão do casamento homossexual.

Oito dos 33 condados do Estado já emitiam licenças de casamento para casais do mesmo sexo desde agosto de 2013. No entanto, funcionários do condado pediram ao

168 Illinois se torna o $16^{\circ}$ estado dos EUA a legalizar o casamento gay. Disponível em: http://g1.globo.com/mundo/noticia/2013/11/illinois-se-torna-o-16o-estado-dos-eua-a-l... Acesso em 03 jan. 2014. 
Tribunal Superior para esclarecer a lei e estabelecer uma política de estado uniforme sobre o casamento homossexual. ${ }^{169}$

No início de 2013, um juiz de Albuquerque decidiu que proibir o matrimônio homossexual era inconstitucional, com fulcro em uma emenda escrita em 1972 que proibia "a discriminação a qualquer pessoa de qualquer sexo". Assim, graças a essa resolução, desde agosto de 2013, em oito dos 33 condados que formam o Novo México já eram emitidas licenças matrimoniais a casais de gays e de lésbicas. A fim de uniformizar o procedimento o caso foi levado ao Tribunal Superior, que decidiu a favor do casamento homossexual. $^{170}$

Em 20 de dezembro de 2013, o juiz federal Robert Shelby declarou ilegal a lei de Utah que impedia o casamento entre pessoas do mesmo sexo. Pouco depois de tal veredito a Procuradoria Geral de Utah apelou à Corte Federal de Apelações do Décimo Circuito em Denver, Colorado e solicitou efeito suspensivo da decisão judicial até que a Corte julgasse o recurso.

As autoridades de Utah querem continuar aplicando a lei que os eleitores do Estado aprovaram em plebiscito em 2004 e que definiu o casamento como uma união só possível entre um homem e uma mulher.

Argumentam, ainda, que a decisão do juiz federal coloca em risco também "o papel único da Suprema Corte como árbitro final da questão constitucional sobre se o casamento homossexual é legal". ${ }^{171}$

Por outro, lado, centenas de casais homossexuais se apressaram para se casar em 23 de dezembro de 2013, após a decisão do juiz federal Robert J. Shelby.

Por enquanto, Utah se junta aos outros dezessete Estados que permitem o casamento homossexual, tornando-se o décimo oitavo Estado a admitir o casamento entre pessoas do mesmo sexo.

169 Novo México legaliza casamento homossexual nos Estados Unidos. Disponível em: http://g1.globo.com/mundo/noticia/2013/12/novo-mexico-legaliza-casamento-homoss... Acesso em 03 jan. 2014.

170 El Tribunal Supremo de Nuevo México legaliza el matrimonio gay. Disponível em: http://sociedad.elpais.com/sociedad/2013/12/19/actualidad/1387483363_160449.html. Acesso em $22 \mathrm{dez}$. 2013.

${ }^{171}$ Governo dos EUA reconhecerá casamento gay em Utah apesar de bloqueio do Supremo. Disponível em: http://operamundi.uol.com.br/conteudo/noticias/33385/governo+dos+eua+reconhecer... Acesso em 15 jan. 2014. 
Utah é considerado o berço da Igreja de Jesus Cristo dos Santos dos Últimos Dias, da religião mórmon, uma das primeiras forças contrárias ao casamento homossexual.

O Governador republicano Gary Herbert também se mostrou decepcionado com a decisão e disse que "um juiz federal ativista está tentando substituir a vontade do povo de Utah". ${ }^{172}$

Em 06 de janeiro de 2014, a Suprema Corte dos Estados Unidos suspendeu temporariamente os casamentos homossexuais em Utah, enquanto não for decidida a apelação do governo estadual contra esse tipo de união.

A decisão deixa em suspenso o veredito anunciado em 20 de dezembro de 2013 pelo juiz federal Robert Shelby, que declarou ilegal a norma que impedia o casamento entre pessoas do mesmo sexo. Até o dia do bloqueio foram realizados 900 casamentos homossexuais.

Com a suspensão dos casamentos entre pessoas do mesmo sexo em Utah cai para dezessete o número de Estados dos Estados Unidos onde são legais os casamentos homossexuais. ${ }^{173}$

Em maio de 2014, por decisão judicial, foi declarada inconstitucional a lei que proibia o casamento homossexual no Estado de Oregon, por violar o direito constitucional dos casais gays e lésbicas de se casarem. A proibição do casamento entre pessoas do mesmo sexo havia sido aprovada durante a disputa presidencial de 2004, na qual o republicano George W. Bush (2001-2009) foi reeleito para governar o país.

A procuradora-geral do Oregon, a democrata Ellen Rosemblum, já tinha rejeitado apresentar uma apelação por entender que não havia base legal após a sentença do Supremo Tribunal de 2013 que declarou inconstitucional a Lei de Defesa do Casamento, que o definia como "a união entre um homem e uma mulher".

\footnotetext{
172 EUA: tribunal legaliza casamento gay no estado de Utah. Disponível em: http://www.estadao.com.br/noticia_imp.php?req=internacional,eua-tribunal-legaliza-c... Acesso em $23 \mathrm{dez}$. 2013.

${ }^{173}$ Supremo dos EUA bloqueia temporariamente casamento gay em Utah. Disponível em: http://noticias.bol.uol.com.br/ultimas-noticias/brasil/2014/01/06/supremo-dos-eua-blo... Acesso em 07 jan. 2014.
} 
Assim, o juiz de distrito, Michael McShane, transformou o Oregon no décimo oitavo Estado da nação, além do Distrito de Colúmbia, a legalizar o casamento homossexual.

Também em outros sete Estados (Oklahoma, Virgínia, Michigan, Texas, Utah, Arkansas e Idaho) os respectivos tribunais derrubaram as proibições do casamento entre homossexuais, embora ainda caiba recurso das sentenças. ${ }^{174}$

\subsubsection{Pensilvânia, Virgínia e Oklahoma}

A Pensilvânia se tornou o décimo nono Estado a permitir o casamento entre pessoas do mesmo sexo nos Estados Unidos em maio de 2014.

O caso chegou aos tribunais por uma denúncia apresentada pela União Americana pelos Direitos Civis (ACLU, sigla em inglês) em nome de vários casais homossexuais. O juiz John Jones considerou inconstitucional a proibição que impedia os casamentos entre homossexuais no Estado e a procuradora-geral do estado, Kathleen Kane não recorreu por questões éticas e por considerar a lei inconstitucional e acrescentou "a desigualdade é inaceitável em qualquer de suas formas, e nunca aguentou a prova do tempo". ${ }^{175}$

O Tribunal Federal de Apelações revogou em 28 de julho de 2014 uma lei do Estado de Virgínia que proibia o casamento entre pessoas do mesmo sexo. Com isso, a Virgínia se torna o vigésimo estado norte-americano a permitir o casamento homossexual.

A Corte insistiu que "Negar a casais do mesmo sexo essa possibilidade os impede de participar totalmente da nossa sociedade, o que é exatamente o tipo de segregação que a $14^{a}$ Emenda da Constituição não pode tolerar."

O governador da Virgínia, o democrata Terry McAuliffe, se disse radiante com a sentença e espera que os cartórios emitam em breve certidões de casamento para os casais de gays e lésbicas.

\footnotetext{
174 Juiz dos EUA anula proibição de casamento gay no estado do Oregon. Disponível em: http://noticia.r7.com/internacional/juiz-dos-eua-anula-proibicao-de-casamento-gay0d... Acesso em 10 de nov. 2014.

175 O matrimônio homossexual já é legal em toda a costa leste dos EUA. Disponível em: http://brasil.elpais.com.br/brasil/2014/05/21/sociedad/1400694107_459810.html. Acesso em 15 mai. 2015.
} 
Em 2006, a população da Virgínia, por meio de um referendo, aprovou uma emenda, com $57 \%$ dos votos, que proibia a união entre pessoas do mesmo sexo, que agora foi derrubada pelo Tribunal Federal em um tipo de ação que tem sido realizada em outros estados dos Estados Unidos. ${ }^{176}$

A proibição do casamento entre pessoas do mesmo sexo em Oklahoma, no sul dos Estados Unidos, foi declarada inconstitucional em 15 de janeiro de 2014 por um juiz federal, um mês após decisão similar envolvendo o estado de Utah, em 20 de dezembro de 2013.

Utah apelou da decisão junto à Suprema Corte que acatou o recurso, suspendendo a decisão adotada em primeira instância, como queria o governador Gary Herbert.

O juiz Terence Kern destacou que sua decisão não será aplicada imediatamente, pois aguarda o resultado final sobre o litígio de Utah.

Nos Estados Unidos, as leis que disciplinam o casamento são estaduais, e cerca de 30 Estados adotaram legislação que proíbem o casamento entre pessoas do mesmo sexo. ${ }^{177}$

Em 06 de outubro de 2014 a Suprema Corte dos Estados Unidos rejeitou as apelações de cinco Estados que buscavam proibir as uniões entre pessoas do mesmo sexo, mas declinou em se pronunciar sobre a legalização do casamento entre pessoas do mesmo sexo em nível nacional. Assim, os Estados de Virgínia, Oklahoma, Utah, Wisconsin e Indiana, a partir de agora permitem o casamento entre pessoas do mesmo sexo. ${ }^{178}$

\subsubsection{Utah, Wisconsin e Indiana}

Em dezembro de 2013, um juiz federal considerou inconstitucional a proibição do casamento entre pessoas do mesmo sexo em Utah, estado conservador onde grande parte

\footnotetext{
176 Virgínia é $20^{\circ}$ estado americano a legalizar casamento gay. Disponível em: http://arpensp.jusbrasil.com.br/noticias/130005677/virginia-e-20o-estado-americano-... Acesso em 18 mai. 2015.

177 Juiz declara inconstitucional lei de Oklahoma contra casamento gay. Disponível em: http://g1.globo.com/mundo/noticia/2014/01/juiz-delcara-inconstitucional-lei-de-oklah... Acesso em 24 mai. 2015.

178 Suprema Corte aprova casamento gay em cinco estados. Disponível em: http://veja.abril.com.br/noticia/mundo/suprema-corte-aprova-casamento-gay-em-cinc... Acesso em 09 nov. 2014.
} 
da população é Mórmon. Porém, o governo do Estado entrou com um recurso na Suprema Corte contra a decisão.

Cerca de 1.300 casamentos homossexuais realizados em Utah entre a decisão do magistrado e o recurso do Estado ficaram num limbo jurídico. Em janeiro de 2014, o governo Obama decidiu reconhecer, pela lei federal, esses casamentos. ${ }^{179}$

Quase dez meses depois, em 06 de outubro de 2014, a Suprema Corte dos Estados Unidos rejeitou os recursos de cinco Estados contra o casamento entre pessoas do mesmo sexo. São eles: Virgínia, Oklahoma, Utah, Wisconsin e Indiana.

Na prática, a Corte decidiu manter decisões de tribunais inferiores que declararam anticonstitucionais leis que proibiram o casamento entre pessoas do mesmo sexo. A rejeição em discutir apelações é sinal de que a Corte ainda não quer se envolver na polêmica, deixando por conta da maioria dos Estados. ${ }^{180}$

Em o6 de junho de 2014, o Tribunal de Wisconsin declarou inconstitucional a lei que proibia o casamento entre pessoas do mesmo sexo. $\mathrm{O}$ recurso foi interposto e somente em 06 de outubro de 2014 a Suprema Corte rejeitou a apelação e manteve a decisão de permitir o casamento entre pessoas do mesmo sexo. ${ }^{181}$

Em 26 de junho de 2014 o Juiz Federal, Richard L. Young, declarou inconstitucional a lei que proibia o casamento entre pessoas do mesmo sexo em Indiana. A decisão também foi motivada pelo pedido de duas lésbicas Amy Sandler e Niki Quasney, juntas há 13 anos e com duas filhas. Quasney foi diagnosticada com câncer em estágio terminal e o casal que já tinha uma união civil assinada em Illinois e um contrato de casamento civil em Massachusetts, em 2013, queria que o seu casamento fosse legalmente reconhecido em Indiana, onde vivem, a fim de garantir as proteções legais, como a capacidade de acessar as redes federais e estaduais de segurança para o cônjuge

\footnotetext{
179 Juíza decide a favor do casamento gay em Estado dos EUA. Disponível em: http://www1.folha.uol.com.br/fsp/mundo/152323-juiza-decide-a-favor-do-casamento-gay-em-estado-doseua.shtm. Acesso em 18 de mai. 2015.

180 Justiça dá aval a união gay em mais 5 Estados dos EUA. Disponível em: http://www1.folha.uol.com.br/fsp/mundo/189449-justica-da-aval-a-uniao-gay-em-mais-5-estados-dos-euashtml Acesso em 18 mai. 2015.

${ }^{181}$ EUA: Bispo Católico do Wisconsin diz que o casamento gay ameaça "tudo o que é belo". Disponível em: http://portugalgay.pt/news/180614C/eua_bispo_catolico_do_wisconsin_diz_que_o_ca... Acesso em 24 mai. 2015.
} 
sobrevivente e seus filhos. Porém só em 06 de outubro de 2014 Indiana pode ver realizado o casamento entre pessoas do mesmo sexo. ${ }^{182}$

\subsubsection{Idaho, Nevada e Virgínia Ocidental}

Em 13 de maio de 2014, de acordo com a juíza Candy Dale a proibição para a união entre pessoas do mesmo sexo no estado americano é inconstitucional e a proibição nega aos gays e lésbicas um direito fundamental. A decisão foi uma resposta à ação movida por quatro casais homoafetivos de Idaho que exigiam o fim da proibição. Dois desses casais têm filhos.

Em 2013, a Suprema Corte dos EUA decidiu que uma lei proibindo o governo federal de reconhecer casamentos do mesmo sexo era inconstitucional. A partir de então, cortes locais têm repetidamente citado a decisão para autorizar o casamento entre pessoas do mesmo sexo em diferentes unidades da federação.

Entretanto, o governador de Idaho, C.L. Otter, irá apelar da decisão. “Em 2006, o povo de Idaho exercitou seu direito fundamental, reafirmando que casamento é a união entre um homem e uma mulher" afirmou o governador em seu discurso.

Idaho é um dos estados mais conservadores dos Estados Unidos e tem uma grande população de mórmons e cristãos evangélicos. ${ }^{183}$

Em 07 de outubro de 2014 o Tribunal de Apelações dos Estados Unidos derrubou a proibição ao casamento entre pessoas do mesmo sexo em Idaho e Nevada. Na sua decisão, o Tribunal de Apelações declarou que as restrições matrimoniais em Idaho e Nevada impunham "profundos danos legais, financeiros, sociais e psíquicos" a casais homossexuais e seus filhos, e classificou como "sem mérito" a afirmação de ambos os estados de que a proibição ao casamento homossexual promoveria o bem-estar das crianças.

\footnotetext{
182 EUA: Proibição ao Casamento Gay em Indiana é derrubada. Disponível em: https://nossostons.wordpress.com/2014/06/26/eua-proibicao-ao-casamento-gay-em-in.. Acesso em 24 de mai. 2015.

${ }^{183}$ Justiça autoriza casamento gay em Idaho, nos EUA, mas governador diz que vai levar "batalha" ao Supremo. Disponível em: http://oglobo.globo.com/sociedade/justifica-autoriza-casamento-gay-em-idahonos-eua-... Acesso em 18 mai. 2015.
} 
Segundo o Tribunal os requerentes são cidadãos comuns de Idaho e Nevada e como todos os seres humanos, suas vidas ganham maior significado graças a seus relacionamentos íntimos e amorosos com seus parceiros e filhos. ${ }^{184}$

Porém, um dia depois de a Corte Federal revogar as proibições vigentes nos Estados de Idaho e Nevada, um juiz da Suprema Corte dos Estados Unidos emitiu ordem suspensiva que impede temporariamente a celebração de casamentos entre pessoas do mesmo sexo nos dois Estados.

Em breve comunicado, o magistrado do Supremo, Anthony Kennedy, disse ter admitido o pedido de suspensão apresentado pelo governador de Idaho, o republicano Butch Otter, que pediu a suspensão da medida pelos riscos potenciais de "caos, confusão, conflitos e incerteza" que, correriam as administrações locais se começassem a celebrar os casamentos entre pessoas do mesmo sexo.

Embora o recurso só tenha sido apresentado pelo governador de Idaho, a suspensão também afeta Nevada, porque a sentença emitida ontem contemplava a revogação das leis contra o casamento homossexual nos dois Estados pelo mesmo motivo, por "violarem o direito da igual proteção diante da lei”. Assim, os favoráveis à revogação da lei em Idaho tem até dois dias para apresentar suas alegações. ${ }^{185}$

Em 9 de outubro de 2014, o veto judicial que proibia o casamento homossexual no estado norte-americano de Nevada foi derrubado. Com o veto à proibição, Nevada passou a ser o trigésimo estado norte-americano a permitir casamento entre pessoas do mesmo sexo. ${ }^{186}$

Em 25 de outubro de 2014 o governo americano reconheceu o casamento homossexual em mais seis Estados, dentre os quais Virgínia Ocidental e Idaho.

\footnotetext{
184 Juízes americanos derrubam proibição do casamento gay em Nevada e Idaho. Disponível em: http://oglobo.globo.com/sociedade/juizes-americanos-derrubam-proibicão-do-casame... Acesso em 19 mai. 2015.

185 Supremo suspende casamento gay em dois Estados dos EUA. Disponível em: http://noticias.terra.com.br/mundo/estados-unidos/supremo-suspende-casamento-gay-... Acesso em 19 mai. 2015.

${ }^{186}$ Estado norte-americano de Nevada aprova lei a favor do casamento homossexual. Disponível em: http://www.luminota.com/pt-br/estado-norte-americano-de-nevada-aprova-lei-a-favor... Acesso em 24 mai. 2015.
} 


\subsubsection{Wyoming, Carolina do Norte, Arizona e Alasca}

Em 25 de outubro de 2014 o governo americano reconheceu o casamento homossexual nos Estados de Wyoming e Carolina do Norte, Arizona e Alasca, além dos citados Virginia Ocidental e Idaho.

No Alasca, em 12 de outubro de 2014, um juiz federal derrubou uma lei estadual que bania o casamento homossexual. Com isso caiu a norma que desde 1988 determinava que casamento é a união entre um homem e uma mulher. A decisão foi motivada por cinco casais homossexuais, que entraram com uma ação contra o estado em maio. Apesar de o governo do Alasca afirmar que irá recorrer da decisão, a Suprema Corte recusa-se a se envolver no debate constitucional sobre o casamento homossexual. Portanto, em 17 de outubro de 2014 a Suprema Corte dos Estados Unidos negou o pedido de suspensão feito pelo governador estadual, tornando-se o trigésimo primeiro estado do país a reconhecer legalmente o casamento homossexual. ${ }^{187}$

\subsubsection{Colorado, Kansas, Carolina do Sul e Montana}

Como a Suprema Corte decidiu não acolher as apelações de cinco estados que pediam a proibição de casamento de pessoas do mesmo sexo, ficou mantida a decisão das cortes nos estados de Virgínia, Oklahoma, Utah, Wisconsin e Indiana e por consequência também nos estados de Carolina do Norte, Carolina do Sul, Virgínia Ocidental, Wyoming, Kansas e Colorado.

O Juiz Distrital do Colorado, C. Scott Crabtree, derrubou em 09 de julho de 2014 a proibição ao casamento homossexual no Estado, pois violava os direitos constitucionais. Disse também que a proibição ao casamento homossexual do Colorado, aprovada pelos eleitores em 2006, entra em conflito com os direitos fundamentais ao casamento.

A Emenda Constitucional do Colorado, que proíbe o casamento homossexual, foi aprovada em 2006 com 55\% dos votos a favor. No entanto, uma pesquisa, feita em abril de 2014 constatou que $61 \%$ dos eleitores do Estado apoiam o casamento homossexual, já entre a faixa etária de 18 a 29 anos, o índice sobe para $81 \%$.

187 Casamento gay é legalizado no Alasca, após recusa do Supremo em suspendê-lo. Disponível em: https://br.noticias.yahoo.com/casamento-gay-\%C3\%A9-legalizado-alasca-recusa-supr... Acesso em 18 mai. 2015. 
O juiz também argumentou que, o fato de o Colorado permitir uniões civis entre pessoas do mesmo sexo desde 2013, não é suficiente, pois é mais uma prova da discriminação contra casais do mesmo sexo. ${ }^{188}$

Em 19 de novembro de 2014, um juiz federal da Suprema Corte de Montana decidiu a favor do casamento homossexual e derrubou uma lei estadual que proibia o casamento civil entre pessoas do mesmo sexo, aprovada desde 2004. Para o juiz Brian Morris, a lei feria a $14^{\mathrm{a}}$ emenda da Constituição dos EUA que garante direitos iguais e igual proteção do Estado a todos os cidadãos. ${ }^{189}$

\subsubsection{Flórida, Alabama e Distrito de Colúmbia}

Em janeiro de 2015 o juiz de distrito Robert Hinkle da Flórida decidiu que as autoridades oficiais não deveriam fazer cumprir uma proibição estatal que fora aprovada pelos eleitores em 2008. Em uma decisão anterior, em agosto, Hinkle disse que proibir o casamento homossexual era inconstitucional e comparou esta medida com a proibição dos casamentos inter-raciais há 50 anos.

Em 2013, a Suprema Corte de Justiça reconheceu a igualdade matrimonial quando revogou uma lei federal que definia o casamento em temos estritamente heterossexuais. Portanto tal decisão deixou para cada um dos 50 estados a decisão de legalizar ou não o casamento de pessoas de mesmo sexo. ${ }^{190}$

O Alabama se tornou o trigésimo sétimo estado americano a permitir o casamento entre pessoas do mesmo sexo, depois que a Suprema Corte recusou uma apelação para impedir a prática.

Nos Estados Unidos, a lei do casamento é de competência do Estado. O Alabama anteriormente proibia os casamentos homossexuais, mas uma decisão da Corte Federal

188 EUA: Juiz derruba proibição ao Casamento Gay no Colorado. Disponível em: https://nossostons.wordpress.com/2014/07/11eua-juiz-derruba-proibicao-ao-casament... Acesso em 19 mai. 2015.

189 EUA: Com Montana, 35 dos 50 estados já aprovaram o casamento gay. Disponível em: http://revistaladoa.com.br/2014/11/noticias/eua-com-montana-35-dos-50-estados-ja-a... Acesso em 19 mai. 2015.

190 Flórida se torna o $36^{\circ}$ estado americano a permitir o casamento gay. Disponível em: http://g1.globo.com/mundo/noticia/2015/01/florida-se-torna-o-36-estado-americano-p... Acesso em 18 mai. 2015. 
derrubou a proibição, dizendo que violava a $14^{\mathrm{a}}$ emenda da Constituição americana a qual garante igualdade de direitos. ${ }^{191}$

O Distrito de Colúmbia passou a reconhecer as parcerias domésticas em 1992, porém somente em 4 de abril de 2006 é que houve a garantia de que em quase todos os casos, os parceiros domésticos teriam os mesmos direitos que os cônjuges.

Posteriormente, em 18 de dezembro de 2009, o casamento entre pessoas do mesmo sexo passou a ser possível, assim que o prefeito do Distrito de Colúmbia sancionou a lei. A partir de 9 de março de 2010, o Distrito passou a emitir licenças de casamento para casais do mesmo sexo. ${ }^{192}$

\subsubsection{Após decisão da Suprema Corte dos Estados Unidos}

Em 26 de junho de 2015, a Suprema Corte dos Estados Unidos aprovou, por 5 votos a 4, o casamento entre pessoas do mesmo sexo em todos os 50 Estados do país, sendo um direito garantido pela Constituição.

O julgamento da ação conhecida como Obergefell vs. Hodges contra os Estados de Kentuchy, Michigan, Ohio e Tennessee, obrigará os treze Estados americanos que ainda não haviam reconhecido legalmente o casamento entre pessoas do mesmo sexo a fazê-lo.

Assim, os treze Estados que faltavam para completar a totalidade dos Estados passaram a partir de então a reconhecer o casamento entre pessoas do mesmo sexo por imposição constitucional. São eles: Dakota do Norte, Dakota do Sul, Nebraska, Missouri, Arkansas, Texas, Lousiana, Mississippi, Geórgia, Tennessee, Kentuchy, Ohio e Michigan.

\footnotetext{
191 Suprema Corte dos EUA autoriza casamento gay no Alabama. Disponível em: http://g1.globo.com/mundo/noticia/2015/02/suprema-corte-dos-eua-autoriza-casament... Acesso em $18 \mathrm{mai}$. 2015.

${ }^{192}$ Same sex marriage in the District of Columbia. Disponível em: http://en.wikipedia.org/wiki/Samesex_marriage_in_the_District_of_Columbia Acesso em 15 jan. 2014.
} 


\subsection{O Casamento não é permitido em todo o território nacional}

\subsubsection{México}

O casamento entre pessoas do mesmo sexo no México é realizado em algumas jurisdições. São legalmente realizados na Cidade do México e no estado de Quintana Roo. Além disso, casais do mesmo sexo têm sido capazes de se casar em casos individuais em Chihuahua, Colima, Yucatán e Oaxaca. Uniões civis do mesmo sexo são legalmente realizadas na Cidade do México e nos estados de Coahuila, Colima e Jalisco. ${ }^{193}$

Em 21 de dezembro de 2009, o México se tornou o primeiro país da América Latina a igualar os direitos dos casais do mesmo sexo em parte de seu território. A nova legislação aplica-se somente ao Distrito Federal. Nesse dia, a capital mexicana aprovou uma reforma do Código Civil que igualou os direitos de todos os casais, permitindo que gays e lésbicas casem no civil e tenham acesso à adoção conjunta.

A lei entrou em vigor em 4 de março de 2010 e teve sua constitucionalidade questionada. Finalmente, em 5 de agosto de 2010, por 8 votos a 2 o Supremo Tribunal do México manifestou-se pela constitucionalidade da norma e que os 31 estados do país devem reconhecer a validade de tais casamentos realizados na capital federal, ou seja, Cidade do México. ${ }^{194}$

Assim, a Cidade do México é, desde 2009, a única entidade federativa que permite, de forma explícita, os casamentos entre pessoas do mesmo sexo. A Suprema Corte de Justiça da Nação resolveu, em 2010, que os 31 estados do país devem reconhecer a validade de tais casamentos realizados na capital.

A cidade de Guadalajara foi palco do primeiro casamento civil homossexual no estado mexicano de Jalisco em 14 de dezembro de 2013.

Zaíra Viridiana de la Gómez e Martha Sandoval Blanco conseguiram se casar graças a uma ação de amparo, autorizadas pela Justiça.

\footnotetext{
193 Casamento entre pessoas do mesmo sexo no México. Disponível em: http://pt.wikipedia.org/wiki/Casamento_entre_pessoas_do_mesmo_sexo_no_M\%C3... Acesso em 28 dez. 2013

194 Same-sex marriage in Mexico City. Disponível em: http://en.wikipedia.org/wiki/Samesex_marriage_in_Mexico_City. Acesso em 03 jan. 2013.
} 
As duas mulheres não quiseram utilizar a Lei de Convivência que foi aprovada em Jalisco no dia 30 de outubro de 2013, porque este trâmite é realizado perante um notário público que firma só um convênio civil entre os casais. ${ }^{195}$

Em agosto de 2010, a Suprema Corte de Justiça do México confirmou que casais homossexuais podem adotar filhos na Cidade do México.

Nove dos 11 juízes votaram a favor do reconhecimento das adoções, encerrando assim o último obstáculo à nova lei, que havia sido alvo de diversos recursos de grupos conservadores.

O governo federal (conservador) recorreu contra a lei do Distrito Federal, alegando que ela viola a proteção da família. Porém os juízes consideraram que não há provas de que a adoção por casais homossexuais seja nociva às crianças. ${ }^{196}$

\subsection{Conclusão}

Este capítulo foi dedicado à pesquisa dos países em que o casamento entre pessoas do mesmo sexo foi legalizado.

Tendo em vista que muitos acontecimentos são recentes e ainda não se encontram em livros científicos socorremo-nos da "internet", uma ferramenta que nos aproxima em tempo real dos fatos.

No entanto, tomamos o devido cuidado de checar todas as informações coletadas, servindo-nos de várias fontes a fim de constatar a coerência e a veracidade dos fatos.

Verificamos que tanto a imprensa estrangeira quanto a imprensa nacional, quando se referem ao casamento homossexual chamam-no de "casamento gay". Esta forma não é adequada porque o casamento entre pares do mesmo sexo envolve o casamento entre dois

\footnotetext{
195 Primeiro casal gay se casa em estado mexicano de Jalisco com amparo judicial. Disponível em: http://noticias.uol.com.br/ultimas-noticias/efe/2013/12/14/primeiro-casal-gay-se-casa-... Acesso em 03 jan. 2014.

196 Justiça aprova adoção por casais gays na Cidade do México. Disponível em: http://oglobo.globo.com/mundo/justica-aprova-adocao-por-casais-gays-na-cidade-do-... Acesso em 12 jan. 2014.
} 
homens (gays) ou entre duas mulheres (lésbicas). Portanto, o nome mais adequado é casamento homossexual (entre duas pessoas do mesmo sexo).

Escolhemos pesquisar sobre o casamento homossexual e não a união civil, porque, atualmente, o casamento homossexual vem sendo aceito em um grande número de países.

Outro ponto de mudança de paradigma muito claro foi que muitos destes países que hoje permitem o casamento homossexual até cerca de vinte ou trinta anos atrás criminalizavam os atos homossexuais. Podemos citar como exemplo: Irlanda, Nova Zelândia e Escócia.

No início de nossa pesquisa, em 2012, tínhamos apenas onze países no mundo que permitiam o casamento: Holanda, Bélgica, Espanha, Canadá, África do Sul, Noruega, Suécia, Portugal, Islândia, Argentina e Dinamarca. Hoje, são em número de dezoito, pois novos países legalizaram o casamento homossexual tais como: Uruguai, Nova Zelândia, França, Reino Unido (Inglaterra, País de Gales, Escócia, excluindo-se a Irlanda do Norte), Luxemburgo, Irlanda e Estados Unidos.

Porém, o país que mais nos causou espanto foi os Estados Unidos, onde atualmente, todos os cinquenta Estados permitem o casamento entre pessoas do mesmo sexo. Lembrando que apenas treze proibiam o casamento homossexual até junho de 2015, sendo eles: Kentucky, Michigan, Ohio, Tennessee, Texas, Lusiana, Arkansas, Georgia, Mississipi, Missouri, North Dakota, South Dakota e Nebrasca.

Quando iniciamos a pesquisa apenas oito Estados permitiam o casamento homossexual: Massachusetts, Connecticut, Iowa, Vermont, New Hampshire, Nova Iorque, Washington e Maine. Posteriormente, até junho de 2013 foram mais nove Estados: Maryland, Rhode Island, Delaware, Minnesota e Califórnia.

O que realmente impulsionou as decisões em favor do casamento homossexual foi o julgamento da Suprema Corte dos Estados Unidos em 26 de junho de 2013 sobre a Lei de Defesa do Casamento (DOMA), porque, após tal julgamento, os casais homossexuais passaram a ter acesso aos mesmos benefícios federais que antes eram reservados exclusivamente aos casais heterossexuais, com relação ao casamento. 
Neste contexto, mais vinte e quatro Estados entenderam ser inconstitucional a proibição do casamento homossexual. São eles: Nova Jersey, Havaí, Illinois, Novo México, Oregon, Pensilvânia, Indiana, Oklahoma, Uthat, Virginia, Wisconsin, Colorado, Nevada, Alasca, Idaho, West Virginia, Carolina do Norte, Arizona, Wyoming, Kansas, Carolina do Sul, Montana, Flórida e Alabama. Para haver uma unificação sobre ao assunto no País todo, foi preciso aguardar a decisão da Suprema Corte dos Estados Unidos em 26 de junho de 2015.

Interessante notar que vinte e seis Estados conseguiram a autorização do casamento homossexual por meio de decisões judicias, oito Estados por meio de legislação estadual, três com plebiscitos e treze com a decisão da Suprema Corte dos Estados Unidos.

Com relação à pesquisa sobre os países que autorizam o casamento homossexual, verificamos algumas diferenças. A primeira diferença se refere à iniciativa da proposta de legalização do casamento homossexual. Em alguns países a iniciativa foi do Poder Executivo tal como na Espanha, Uruguai, Nova Zelândia e França; outras do Poder Judiciário tal como Canadá, África do Sul, Portugal e Argentina, outras do Poder Legislativo tal como Holanda, Bélgica, Noruega, Islândia, Dinamarca, Inglaterra, País de Gales Escócia, e Luxemburgo e outros ainda por meio de referendo popular, como foi o caso recente da Irlanda.

Sobre os efeitos do casamento homossexual em relação aos filhos, alguns países admitem a presunção de paternidade e outros não; uns permitem a reprodução medicamente assistida e gestação de substituição, outros só admitem a adoção e outros ainda, como Portugal, não permitem sequer a adoção.

O fundamento sobre a aceitação do casamento homossexual nos vários países pesquisados foi, de maneira geral: que o matrimônio é um direito constitucional da pessoa; que a homossexualidade é uma característica profundamente pessoal, imutável ou mutável somente a custos pessoais inaceitáveis; atendimento ao princípio constitucional da igualdade; que a discriminação baseada na orientação sexual viola a dignidade humana; que há vedação constitucional à discriminação com relação a sexo, raça, religião e orientação sexual; que não se deve cogitar de ausência normativa, mas de simples omissão, não vedando a lei o casamento entre pessoas do mesmo sexo; mesmos direitos com o mesmo nome, ou seja, casamento igualitário, ou sexualmente neutro. 
Outro fato importante para o direito foi que a Teoria do Casamento Inexistente, prevista explicitamente nos ordenamentos jurídicos de Portugal e da Argentina restou modificada pela alteração das respectivas legislações. Logo a diversidade de sexo não é mais causa de inexistência do casamento nestes dois países.

Portanto, parece-nos que apesar de ainda existirem a intolerância e o preconceito contra os pares homossexuais, os conceitos de homossexualidade como pecado, homossexualidade como crime e homossexualidade como doença estão, aos poucos, perdendo sua importância. 


\title{
PARTE 2
}

\section{A FAMÍLIA HOMOAFETIVA NO ORDENAMENTO JURÍDICO BRASILEIRO}

Antes das Constituições brasileiras, o que vigorava entre nós eram as Ordenações Filipinas, que impingiam aos atos homossexuais a pecha de gravidade extrema. Havia no Direito Estatal a prevalência das convicções religiosas em relação à homossexualidade, cujo grau pode ser verificado em seu texto:

\begin{abstract}
"Toda pessoa, de qualquer qualidade que seja, que pecado de sodomia por qualquer maneira cometer, seja queimado e feito por fogo em pó, para que nunca de seu corpo e sepultura possa haver memória, e todos seus bens sejam confiscados para a coroa de nossos Reinos, posto que tenha descendentes; e pelo mesmo caso seus filhos e netos ficarão inabilitados e infames, assim como os daqueles que comete o crime de Lesa- Majestade.
\end{abstract}

1. E esta lei queremos, que também se estenda e haja lugar nas mulheres, que umas com as outras cometem pecado contra a natureza e da maneira que temos dito nos homens.

2. Outrossim qualquer homem ou mulher, que carnalmente tiver ajuntamento com alguma alimária, seja queimado e feito em pó. Porém por tal condenação não ficarão seus filhos, nem descendentes neste caso inabilitados, nem infames, nem lhes fará prejuízo algum acerca da sucessão, nem a outros, que por Direito seus bens devam herdar. ${ }^{197}$

Com a evolução do pensamento, os iluministas, embora não aceitassem a homossexualidade, começaram a considerar uma atrocidade puni-la com a morte e, o Código Napoleônico de 1810 descriminalizou as práticas privadas e consensuais entre adultos do mesmo sexo, o que influenciou a legislação brasileira no mesmo sentido. ${ }^{198}$

Ensinam os professores Carlos Alberto e Adriana Dabus Maluf que a primeira Constituição brasileira, a Constituição Imperial de 1824, não continha nenhuma referência relevante ao direito de família. Neste período, o vínculo estreito entre a Igreja e o Estado fazia existir apenas o casamento religioso como fonte formal da família.

197 RIOS, Roger Raupp. O Princípio da Igualdade e a Discriminação por Orientação Sexual. A Homossexualidade no Direito Brasileiro e Norte-Americano. São Paulo: RT, 2002, p. 104-105.

198 VECCHIATTI, Paulo Roberto Iotti. Manual da Homoafetividade. 2 ed. revista e atualizada. São Paulo: Gen. Método, 2012, p. 39. 
A Constituição de 1891, redigida por Rui Barbosa e promulgada em 24 de fevereiro de 1891, de cunho liberal, proclamou o casamento civil de celebração gratuita e desvinculou a instituição matrimonial da religião, separando Estado e Igreja. A República, pelo Decreto 181, de 1890, instituiu o casamento civil, de gratuita celebração, passando a ser este o único ato jurídico capaz de constituir a família e tornando inexistente o casamento celebrado apenas no religioso. ${ }^{199}$

A Constituição de 1934 foi a primeira constituição a se preocupar em delinear a família em seu contexto. Estimulou a indissolubilidade do casamento, ressalvadas as hipóteses de desquite ou anulação, inserindo, assim, a temática da família em seu corpo. $\mathrm{O}$ casamento continuava civil e gratuito, aceitando os efeitos do casamento religioso. Acrescentou a gratuidade do reconhecimento dos filhos naturais, garantias que foram repetidas na Constituição de 1937, de 10 de novembro de 1937, com o acréscimo da igualdade entre filhos naturais e legítimos e proteção da infância e da juventude pelo Estado. Não estendeu, entretanto, por norma constitucional, os efeitos civis ao casamento religioso, que ocorreu com a Lei no 379, de 16 de janeiro de 1937.

A Constituição de 1946, com relação à família, renovou os direitos anteriormente concedidos, apenas adicionando a vocação hereditária de brasileiros, em relação a bens deixados por estrangeiros no país.

A Constituição de 1967 em nada alterou a proteção da família em relação às Constituições precedentes, mantendo a ideia de que a família somente era aquela constituída pelo casamento civil de caráter indissolúvel e de gratuita celebração, o casamento religioso com efeitos civis e a garantia da proteção à maternidade, infância e adolescência.

A Emenda $\mathrm{n}^{\circ}$ 1, de 1969, manteve o casamento indissolúvel, mas foi modificado com o advento da Lei do Divórcio de 1977, estatuindo-se que o casamento podia ser dissolvido após previa separação judicial por três anos e, mais tarde, pela Emenda $n^{\circ} 2$, de 1977, que permitiu o divórcio direto, para separações de fato por mais de cinco anos, se anteriores à Emenda.

199 MALUF, Carlos Alberto Dabus. A inexistência na teoria das nulidades. Tese apresentada ao Departamento de Direito Civil da Faculdade de Direito da USP para provimento de cargo de Professor Titular, 2006, p. 145. 
A aceitação de novos paradigmas como a independência da mulher, uma nova consciência sobre a sexualidade, o crescimento de movimentos reivindicatórios e a abertura política foram alguns dos acontecimentos que desembocaram no processo constituinte, dando origem a uma nova ordem constitucional. ${ }^{200}$

A Constituição de 1988 representou uma nova conceituação de entidade familiar, passando a família a ser vista e aceita de forma mais ampla. Consagra a Constituição atual a proteção à família no artigo 226, sendo esta formada pelo casamento civil ou religioso com efeitos civis $\left(\S \S 1^{\circ}\right.$ e 2$)$, pela união estável entre o homem e a mulher, facilitada sua conversão em casamento $\left(\S 3^{\circ}\right)$ e pela família monoparental, comunidade formada por qualquer dos pais e seus descendentes $\left(\S 4^{\circ}\right)$; sedimenta a igualdade de direitos e deveres entre os cônjuges $\left(\S 5^{\circ}\right)$; assim como a hipótese de dissolução do casamento pelo divórcio $\left(\S 6^{\circ}\right)$; estabelece que, fundado nos princípios da dignidade da pessoa humana e da paternidade responsável, o planejamento familiar é de livre decisão do casal $\left(\S 7^{\circ}\right)$; dispõe que o Estado assegurará assistência à família na pessoa de cada um dos que a integra, criando mecanismos para coibir a violência no âmbito de suas relações $\left(\S 8^{\circ}\right)$. Fixou também a igualdade entre os filhos, havidos ou não do casamento ou por adoção, sendo vedada qualquer forma de discriminação em matéria de filiação (art. 227, § $6^{\circ}$ ).

Aplicam-se ao direito de família os princípios constitucionais da dignidade da pessoa humana (art. $1^{\circ}$, III), o princípio e objetivo da promoção da sociedade, sem preconceitos de origem, raça, sexo, cor, idade e quaisquer outras formas de discriminação (art. $\left.3^{\circ}, \mathrm{IV}\right)$. Além disso, o artigo $5^{\circ}, \mathrm{X}$ consagra o direito à intimidade. Portanto, como aspectos do exercício desse direito, tem-se a orientação e a prática sexual livres de discriminações.

$\mathrm{O}$ art. $5^{\circ}$ declara que todos são iguais perante a lei, dando ênfase no inciso I que homens e mulheres são iguais em direitos e obrigações nos termos da Constituição e consagrando no inciso II, que ninguém será obrigado a fazer ou deixar de fazer alguma coisa senão em virtude de lei. ${ }^{201}$

\footnotetext{
${ }^{200}$ MALUF, Carlos Alberto Dabus. MALUF, Adriana Caldas do Rego Freitas Dabus . Curso de Direito de Família. São Paulo: Saraiva, 2013, p. 58-63.

${ }^{201}$ FRANÇA PINTO, Ana Cristina de Barros Monteiro. Reflexões sobre o vínculo homoafetivo no direito sucessório. In 10 anos de Vigência do Código Civil Brasileiro de 2002. Estudos em homenagem ao professor Carlos Alberto Dabus Maluf. São Paulo: Saraiva, 2013, p. 601.
} 
Assim, todo um modo novo de ver o direito emerge da Constituição Federal de 1988, verdadeira carta de princípios que impôs eficácia a todas as suas normas definidoras de direitos e de garantias fundamentais (art. $5^{\circ} \S 1^{\circ}$ ).

Princípio é, por definição, mandamento nuclear de um sistema e, como diz Celso Antonio Bandeira de Mello, violar um princípio é muito mais grave que transgredir uma norma. A desatenção ao princípio implica ofensa não apenas a um princípio mandamental obrigatório, mas a todo o sistema de comandos. ${ }^{202}$

\subsection{Uniões homoafetivas e proteção constitucional}

A Constituição de 1988, no artigo $1^{\circ}$ afirma constituir nossa República num Estado Democrático de Direito.

Assim, não pode haver democracia onde não existam homens e mulheres autônomos e independentes em sua diversidade e pluralismo.

Um breve olhar sobre o rol de direitos humanos insertos em nossa Constituição revela implicações evidentes entre a livre expressão da sexualidade por parte dos homossexuais e o princípio da dignidade da pessoa humana, um dos fundamentos da República Federativa do Brasil. Sob o manto do princípio da igualdade, presente não só nos direitos fundamentais do artigo $5^{\circ}$ da Constituição, mas também no artigo $3^{\circ}$, inciso IV, encontram-se o direito à intimidade e à vida privada, e da liberdade de expressão. ${ }^{203}$

A condição de integrante de uma família é condição essencial de vida para todos os indivíduos e é essa condição que se faz necessária proteger. Conforme relatado pelo Ministro Celso de Mello no Agravo Regimental no Recurso Extraordinário 477.554/MG, de 16/08/2011 ${ }^{204}$.

\footnotetext{
${ }^{202}$ DIAS, Maria Berenice. Manual de Direito das Famílias. $6^{a}$ ed. Revista, atualizada e ampliada. São Paulo: RT, 2010, p. 58.

${ }^{203}$ RIOS, Roger Raupp. A igualdade de tratamento nas relações de família. In A Justiça e os Direitos de Gays e Lésbicas. Jurisprudência Comentada. Francisco Loyola de Souza...[et.al]; Orgs. Célio Golin. Porto Alegre: Sulina, 2003, p. 178.

204 RE 477554 AgR /MG - Minas Gerais Disponível em: http://www.stf.jus.br/portal/jurisprudenciaDetalhe.asp?s1=000178 ... Acesso em 04 jul. 2015.
} 
RE 477554 AgR/MG - Minas Gerais, AG.REG. no Recurso Estraordinário; Relator: Min. Celso de Mello; Julgamento: 16/08/2011 Órgão Julgador: Segunda Turma

EMENTA: UNIÃO CIVIL ENTRE PESSOAS DO MESMO SEXO ALTA RELEVÂNCIA SOCIAL E JURÍDICO-CONSTITUCIONAL DA QUESTÃO PERTINENTE ÀS UNIÕES HOMOAFETIVASLEGITIMIDADE CONSTITUCIONAL DO RECONHECIMENTO E QUALIFICAÇÃO DA UNIÃO ESTÁVEL HOMOAFETIVA COMO ENTIDADE FAMILIAR: POSIÇÃO CONSAGRADA NA JURISPRUDÊNCIA DO SUPREMO TRIBUNAL FEDERAL (ADPF 132/RJ E ADI 4.277/DF) - O AFETO COMO VALOR JURÍDICO IMPREGNADO DE NATUREZA CONSTITUCIONAL: A VALORIZAÇÃO DESSE NOVO PARADIGMA COMO NÚCLEO CONFORMADOR DO CONCEITO DE FAMÍLIA - O DIREITO À BUSCA DA FELICIDADE, VERDADEIRO POSTULADO CONSTITUCIONAL IMPLÍCITO E EXPRESSÃO DE UMA IDEIAFORÇA QUE DERIVA DO PRINCÍPIO DA ESSENCIAL DIGNIDADE DA PESSOA HUMANA - ALGUNS PRECEDENTES DO SUPREMO TRIBUNAL FEDERAL E DA SUPREMA CORTE AMERICANA SOBRE O DIREITO FUNDAMENTAL À BUSCA DA FELICIDADE - PRINCÍPIOS DE YOGYAKARTA (2006): DIREITO DE QUALQUER PESSOA DE CONSTITUIR FAMÍLIA, INDEPENDENTEMENTE DE SUA ORIENTAÇÃO SEXUAL OU IDENTIDADE DE GÊNERO - DIREITO DO COMPANHEIRO, NA UNIÃO ESTÁVEL HOMOAFETIVA, À PERCEPÇÃO DO BENEFÍCIO DA PENSÃO POR MORTE DE SEU PARCEIRO, DESDE QUE OBSERVADOS OS REQUISITOS DO ART. 1.723 DO CÓDIGO CIVIL - O ART. 226, $\S 3^{\circ}$, DA LEI FUNDAMENTAL CONSTITUI TÍPICA NORMA DE INCLUSÃO - A FUNÇÃO CONTRAMAJORITÁRIA DO SUPREMO TRIBUNAL FEDERAL NO ESTADO DEMOCRÁTICO DE DIREITO - A PROTEÇÃO DAS MINORIAS ANALISADAS NA PERSPECITIVA DE UMA CONCEPÇÃO MATERIAL DE DEMOCRACIA CONSTITUCIONAL - O DEVER CONSTITUCIONAL DO ESTADO DE IMPEDIR (E, ATÉ MESMO, DE PUNIR) "QUALQUER DISCRIMINAÇÃO ATENTATÓRIA DOS DIREITOS E LIBERDADES FUNDAMENTAIS" (CF, ART. 5', XLI) - A FORÇA NORMATIVA DOS PRINCÍPIOS CONSTITUCIONAIS E O FORTALECIMENTO DA JURISDIÇÃO CONSTITUCIONAL: ELEMENTOS QUE COMPÕEM O MARCO DOUTRINÁRIO QUE CONFERE SUPORTE TEÓRICO AO NEOCONSTITUCIONALISMO - RECURSO DE AGRAVO IMPROVIDO. NINGUÉM PODE SER PRIVADO DE SEUS DIREITOS EM RAZÃO DE SUA ORIENTAÇÃO SEXUAL.

Quanto à igual proteção das leis e do sistema político-jurídico, enfatiza o ilustre relator que:

Ninguém, absolutamente ninguém, pode ser privado de direitos nem sofrer quaisquer restrições de ordem jurídica por motivo de sua orientação sexual. Os homossexuais, por tal razão, têm direito de receber a igual proteção tanto das leis quanto do sistema-político-jurídico instituído pela Constituição da República, mostrando-se arbitrário e inaceitável qualquer estatuto que puna, que exclua, que discrimine, que 
fomente a intolerância, que estimule o desrespeito e que desiguale as pessoas em razão de sua orientação sexual.

Com relação ao conceito de união homoafetiva como entidade familiar, este é claro e não deixa dúvidas:

O Supremo Tribunal Federal apoiando-se em valiosa hermenêutica construtiva e invocando princípios essenciais (como os da dignidade da pessoa humana, da liberdade, da autodeterminação, da igualdade, do pluralismo, da intimidade, da não discriminação e da busca da felicidade) - reconhece assistir a qualquer pessoa, o direito fundamental à orientação sexual, havendo proclamado, por isso mesmo, a plena legitimidade éticojurídica da união homoafetiva como entidade familiar, atribuindo-lhe, em consequência, verdadeiro estatuto de cidadania, em ordem a permitir que se extraiam, em favor de parceiros homossexuais, relevantes consequências no plano do Direito, notadamente no campo previdenciário, e, também, na esfera das relações sociais e familiares.

Quanto à extensão para as uniões homoafetivas do mesmo regime jurídico aplicável à união estável entre pessoas de gênero distinto:

\begin{abstract}
A extensão às uniões homoafetivas, do mesmo regime jurídico aplicável à união estável entre pessoas de gênero distinto justifica-se e legitima-se pela direta incidência, dentre outros, dos princípios constitucionais da igualdade, da liberdade, da dignidade, da segurança jurídica e do postulado constitucional implícito que consagra o direito à busca da felicidade, os quais configuram, numa estrita dimensão que privilegia o sentido de inclusão decorrente da própria Constituição da República (art. $1^{\circ}$, III, e art. $\left.3^{\circ}, I V\right)$, fundamentos autônomos e suficientes aptos a conferir suporte legitimador à qualificação das conjugalidades entre pessoas do mesmo sexo como espécie do gênero entidade familiar. Toda pessoa tem $o$ direito fundamental de constituir família, independentemente de sua orientação sexual ou de identidade de gênero. A família resultante da união homoafetiva não pode sofrer discriminação, cabendo-lhes os mesmo direitos, prerrogativas, benefícios e obrigações que se mostrem acessíveis a parceiros de sexo distinto que integrem uniões heteroafetivas.
\end{abstract}

A função contramajoritária do Supremo Tribunal Federal e a proteção das minorias:

A proteção das minorias e dos grupos vulneráveis qualifica-se como fundamento imprescindível à plena legitimação material do Estado Democrático de Direito. Incumbe, por isso mesmo, ao Supremo Tribunal Federal, em sua condição Institucional de guarda da Constituição (o que lhe confere "o monopólio da última palavra" em matéria de interpretação constitucional), desempenhar função contramajoritária, em ordem a dispensar efetiva proteção às minorias contra eventuais excessos (ou omissões) da maioria, eis que ninguém se sobrepõe, nem mesmo os grupos majoritários, à autoridade hierárquico-normativa e aos princípios superiores consagrados na Lei Fundamental do Estado. 


\subsubsection{Princípio da dignidade da pessoa humana}

Ensina Paulo Lobo que um dos maiores avanços do direito brasileiro, principalmente após a Constituição de 1988, é a consagração da força normativa dos princípios constitucionais explícitos e implícitos, deixando o efeito simbólico que a doutrina tradicional a eles destinava. Sem a mediação realizadora do Poder Judiciário, os princípios não se realizam nem adquirem a plenitude de sua força normativa. São Princípios Fundamentais: 1) dignidade da pessoa humana; 2) solidariedade. São Princípios Gerais: 3) igualdade; 4) liberdade; 5) afetividade; 6) convivência familiar e 7) melhor interesse da criança. ${ }^{205}$

A Constituição Federal, logo em seu art. $1^{\circ}$ estabelece que "a República Federativa do Brasil, formada pela união indissolúvel dos Estados e Municípios e do Distrito Federal, constitui-se em Estado Democrático de Direito e tem como fundamento: I - a soberania; II - a cidadania; III- a dignidade da pessoa humana; (...)". Como consequência, desse princípio estar presente na Constituição, temos que seus efeitos se irradiam por todo o ordenamento jurídico, isto é, por todos os ramos do direito positivo nacional.

Kant procurou distinguir aquilo que tem um preço, seja pecuniário, seja estimativo, do que é dotado de dignidade, isto é, do que é inestimável, do que é indisponível, do que não pode ser objeto de troca. Assim afirma: "No reino dos fins tudo tem ou um preço ou uma dignidade. Quando uma coisa tem um preço, pode-se pôr em vez dela qualquer outra como equivalente; mas quando uma coisa está acima de todo o preço, e, portanto, não permite equivalente, então tem ela dignidade". Portanto, viola o princípio da dignidade da pessoa humana todo ato, conduta ou atitude que coisifique a pessoa, ou seja, que a equipare a uma coisa disponível, ou a um objeto. ${ }^{206}$

Ao contrário da doutrina racionalista de Kant, Ingo Wolfgang Sarlet defende que o desenvolvimento cultural das sociedades humanas e sua consequente evolução também caracterizam o conteúdo do que efetivamente se considera como "dignidade da pessoa humana", especialmente em relação às condutas que a ofendem em complementação à

\footnotetext{
${ }^{205}$ LÔBO, Paulo. Direito Civil. Famílias. 3 ed. São Paulo: Saraiva, 2010, p. 50-53.

${ }^{206}$ LÔBO, Paulo. Direito Civil. Famílias. 3 ed. São Paulo: Saraiva, p. 53.
} 
concepção biológica da dignidade. Portanto, entende o autor que a dignidade humana é tanto um limite para a atuação estatal, que não pode invadi-la, quanto um dever prestacional do Estado, o qual tem por obrigação tomar todas as medidas necessárias a fim de garantir que todas as pessoas humanas tenham sua dignidade respeitada por toda a coletividade. $^{207}$

Princípio jurídico da proteção da dignidade da pessoa humana e orientação sexual, como se correlacionam? Preliminarmente é necessário definir o que seja orientação sexual. Ensina Roger Raupp Rios que orientação sexual é a identidade atribuída a alguém em função da direção de seu desejo e condutas sexuais, seja para outra pessoa do mesmo sexo (homossexualidade), do sexo oposto (heterossexualidade) ou de ambos os sexos (bissexualidade).

Assim, na construção da individualidade de uma pessoa, a sexualidade é uma dimensão fundamental na constituição da subjetividade, que é o alicerce indispensável para o livre desenvolvimento da personalidade. Logo, as questões relativas à orientação sexual relacionam-se de modo íntimo com a proteção da dignidade da pessoa humana. ${ }^{208}$

\subsubsection{Princípio da igualdade e direito à diferença}

Nenhum princípio da Constituição Federal trouxe tão profunda transformação no direito de família quanto o da igualdade entre homem e mulher, entre filhos e entre entidades familiares de acordo com Paulo Lobo. Assim, o princípio geral da igualdade de gêneros foi igualmente elevado ao status de direito fundamental, oponível aos poderes políticos e privados, conforme art. $5^{\circ}$, I, da Constituição Federal.

O princípio constitucional da igualdade dirige-se ao legislador, vedando-lhe que edite normas que o contrariem, à administração pública, para que implemente políticas públicas para superação das desigualdades reais existentes entre os gêneros, e à administração da justiça, para o impedimento das desigualdades, cujos conflitos

207 VECCHIATTI, Paulo Roberto Iotti. Manual da Homoafetividade. Da possiblidade jurídica do casamento civil, da união estável e da adoção por casais homoafetivos. 2 ed. São Paulo: Gen., Método, 2012 , p. 126.

${ }^{208}$ RIOS, Roger Raupp. A homossexualidade no Direito. Porto Alegre: Livraria do Advogado, 2001, p. 90 91. 
provocaram sua intervenção. É sabido que costumes e tradições, transmitidos de geração a geração sedimentaram condutas de opressão e submissão, no ambiente familiar, mas não podem ser obstáculos à plena realização do direito. ${ }^{209}$

O princípio da igualdade possui um duplo aspecto no ordenamento jurídico brasileiro: um aspecto formal e um aspecto material.

Em seu aspecto formal, o princípio da igualdade estabelece a denominada igualdade perante a lei, que determina a igual aplicação do Direito vigente a todos os indivíduos, sem serem consideradas as características pessoais específicas dos cidadãos sujeitos à legislação a ser aplicada.

Porém, a realidade prática deixou clara que a aplicação do princípio da igualdade em seu aspecto meramente formal dá margem a uma série de arbitrariedades, tendo em vista que possibilita a inversão total da famosa definição de Aristóteles, que fundamenta o preceito isonômico segundo ao qual se deve tratar igualmente os iguais e desigualmente os desiguais, na medida de sua desigualdade.

Assim, conclui-se pela insuficiência da compreensão meramente formal do preceito isonômico, que demandou por uma consideração também material, proibitiva de tratamento desigual de situações idênticas ou análogas, mesmo que tal diferenciação arbitrária fosse instituída por lei. ${ }^{210}$

Em seu aspecto material, o princípio da igualdade consagra a célebre definição de igualdade de Aristóteles, uma vez que define que deve ser dado o mesmo tratamento jurídico aos indivíduos que se encontrem em situação idêntica ou análoga, ao passo que aos que se encontrem em situação diversa deve ser dado um tratamento jurídico diverso. É a denominada igualdade na lei.

\footnotetext{
${ }^{209}$ LÔBO, Paulo. Direito Civil. Famílias. 3 ed. São Paulo: Saraiva, p. 58-59.

210 VECCHIATTI, Paulo Roberto Iotti. Manual da Homoafetividade. Da possiblidade jurídica do casamento civil, da união estável e da adoção por casais homoafetivos. $2^{\text {a }}$ ed. São Paulo: Gen., Método, 2012, p. 91-93.
} 


\subsubsection{Princípio da afetividade}

O princípio da afetividade concretiza, no âmbito familiar, os princípios constitucionais da dignidade da pessoa humana (art. $1^{\circ}$, III) e da solidariedade (art. $\left.3^{\circ}, \mathrm{I}\right)$, e é entrelaçado pelos princípios da convivência familiar (art. 227) e da igualdade entre cônjuges (art. 226, $\S 5^{\circ}$ ). Esse princípio faz aflorar a igualdade entre irmãos biológicos e adotivos e o respeito a seus direitos fundamentais, conforme se verifica no (art. 226, $\S 6^{\circ}$ ) todos da Constituição Federal. ${ }^{211}$

Ao serem reconhecidas como entidade familiar merecedora da tutela jurídica as uniões estáveis demonstram que a afetividade, que une duas pessoas, adquiriu reconhecimento e inserção no sistema jurídico. Também o afeto está presente no reconhecimento da filiação socioafetiva (art.1.593 do Código Civil), admitindo outra origem à filiação além do parentesco natural e civil. ${ }^{212}$

Por fim, o afeto se faz presente em relação ao casamento (art. 1.511 do Código Civil) em que a plena comunhão de vida é pressuposto do afeto.

Assim, relacionando os princípios da liberdade, da não discriminação por razão de sexo e orientação sexual e o princípio da igualdade, pode-se concluir que as uniões homoafetivas também estão sob a proteção do princípio constitucional da afetividade. ${ }^{213}$

\section{2 $O$ vazio legislativo quanto às uniões homoafetivas}

Apesar de todos os princípios citados, os pares homossexuais não tinham a possibilidade de formular e de perseguir autonomamente os seus planos de vida e buscar a própria realização existencial. Não podiam casar nem tampouco constituir união estável sob a proteção do Estado, tal como os pares heterossexuais, sem qualquer justificativa aceitável, a não ser pelo preconceito.

\footnotetext{
${ }^{211}$ LÔBO, Paulo. Direito Civil. Famílias. 3 ed. São Paulo: Saraiva, p. 64.

${ }^{212}$ DIAS, Maria Berenice. Manual de Direito das Famílias. 6 ed. revista, atualizada e ampliada. São Paulo: RT, 2010, p.70.

213 CHAVES, Marianna. Homoafetividade e Direito. Proteção Constitucional, Uniões, Casamento e Parentalidade. 2 ed. Curitiba: Juruá, 2012, p. 88.
} 
Por óbvio, sob a aparente neutralidade da legislação infraconstitucional brasileira, que apenas protegeu juridicamente as relações estáveis heterossexuais, esconde-se o mais insidioso preconceito contra os homossexuais. Porém, esta orientação está em profunda desarmonia com o projeto do constituinte de 88 , que pretendeu instalar uma "sociedade fraterna, pluralista e sem preconceitos", como consta do Preâmbulo da Constituição.

Sobre esta questão, José Afonso da Silva deixou claro que a abrangência da vedação constitucional às outras formas de discriminação é suficiente para englobar aquelas fundadas na orientação sexual, já que este é também um fator que tem servido de fundamento para desequiparações e preconceitos ${ }^{214}$.

Importante frisar que o vazio legislativo não equivale à ausência de direitos. Assim, os pares homossexuais vêm conquistando seus direitos por meio do Poder Judiciário, tendo em vista a inércia do Poder Legislativo. No entanto, com fundamento no princípio constitucional da igualdade, seria importante não só para os casais homossexuais, como para a sociedade como um todo, que o legislador legislasse a respeito do tema, como já ocorreu em muitos países conforme visto nesta pesquisa.

A importância de uma lei é porque esta assegura direitos e pressupõe limites efetivando, deste modo, a segurança jurídica das relações entre pares do mesmo sexo.

\subsection{Conclusão}

Os relacionamentos homossexuais, quando entre nós o que vigorava eram as Ordenações Filipinas, eram tipificados como crime e apenados com a morte.

As convicções religiosas eram tão intrínsecas ao Estado que o fato típico e antijurídico do crime era o pecado da sodomia.

Não somente a homossexualidade masculina, mas, também, a feminina eram punidas.

${ }^{214}$ SILVA, José Afonso. Comentário Contextual à Constituição. São Paulo: Malheiros, 2005, p. 48. 
A pena passava da pessoa do apenado e atingia seus filhos e netos que se tornavam inabilitados e infames tal como aqueles que cometessem o crime de LesaMajestade.

Portanto, no Brasil, também tivemos os conceitos de homossexualidade como pecado e como crime presentes na formação da consciência de nosso povo.

A partir do Código de Napoleão de 1810, que descriminalizou as práticas privadas e consensuais entre adultos do mesmo sexo, nossa legislação também teve tal influência.

As Constituições brasileiras de uma forma ou de outra sempre trouxeram referências à família e ao direito de família. Numa mudança constante o casamento formador da família passou de religioso a civil, sendo acolhido posteriormente os efeitos civis do casamento religioso. Quanto à duração, passou de indissolúvel à possibilidade de ser dissolvido. A Constituição de 1988 trouxe uma nova conceituação de entidade familiar, passando a família a ser vista e aceita de forma mais ampla não só pelo casamento civil e pelo casamento religioso com efeitos civis, mas também pela união estável entre homem e mulher, facilitada sua conversão em casamento e pela família monoparental, comunidade formada por qualquer dos pais e seus descendentes.

Percebe-se, portanto, que à medida que a sociedade se modificava também a família e o direito de família se modificavam.

Assim, todo um modo de ver o direito emergiu da Constituição Federal de 1988, uma verdadeira Carta de Princípios que impôs eficácia a todas as suas normas definidoras de direitos e de garantias fundamentais, de acordo com seu art. $5^{\circ}, \S 1^{\circ}$.

Aplicam-se ao direito de família os princípios constitucionais da dignidade da pessoa humana (art. $1^{\circ}$, III), o princípio e objetivo da proteção da sociedade, sem preconceitos de origem, raça, sexo, cor, idade e quaisquer outras formas de discriminação (art. $\left.3^{\circ}, \mathrm{IV}\right)$. Além disso, o art. $5^{\circ}, \mathrm{X}$ consagra o direito à intimidade. Portanto, como aspectos do exercício desse direito, tem-se a orientação e a prática sexual livres de discriminações.

A sexualidade é uma dimensão fundamental na constituição da subjetividade, que é o alicerce indispensável para o livre e sadio desenvolvimento da personalidade. Portanto, 
as questões relativas à orientação sexual relacionam-se de modo íntimo com a proteção da dignidade da pessoa humana.

Em nossos estudos verificamos que o princípio constitucional da igualdade dirigese também ao legislador, vedando-lhe que edite normas as quais incitem a desigualdade.

O princípio da afetividade está presente no reconhecimento das uniões estáveis como entidade familiar merecedora da tutela jurídica e no reconhecimento pelo Supremo Tribunal Federal das uniões homoafetivas como entidade familiar equiparando-as às uniões estáveis heteroafetivas.

Ainda o afeto está presente no reconhecimento da filiação socioafetiva (artigo 1.593, CC) e também com relação ao casamento (art. 1.511, CC) em que a plena comunhão de vida é pressuposto do afeto.

Quanto ao vazio legislativo, este não equivale à ausência de direitos. No entanto, seria muito importante, não só aos pares homossexuais, mas a toda sociedade, uma legislação que assegurasse direitos e fixasse limites aos relacionamentos entre os pares homossexuais, como já visto em outros países. 


\section{A UNIÃO ESTÁVEL E A UNIÃO HOMOAFETIVA}

Em nossa legislação, até os dias de hoje, não há qualquer referência às uniões homoafetivas como sinônimo de família. Não há proibição, mas também não há tratamento específico do tema. Há um vazio legislativo, que vem sendo preenchido pelos princípios constitucionais, pela doutrina e pela jurisprudência.

$\mathrm{O}$ artigo 226, $\S 3^{\circ}$, da Constituição Federal e o artigo 1.723 do Código Civil reconhecem a união estável entre homem e mulher, embora não haja proibição quanto à união estável entre pessoas do mesmo sexo.

De fato, o Código Civil ao disciplinar a união estável, circunscreveu-a às relações existentes entre homem e mulher, mantendo a orientação legislativa anterior, trazida pelas Leis $8.971 / 94$ e $9.278 / 96$.

Inicialmente, com relação às uniões homoafetivas, quando chegavam às portas do Poder Judiciário entendia-se que havia a impossibilidade jurídica do pedido. Ao depois se reconheceu nestas uniões apenas o direito patrimonial, sendo caracterizadas como sociedade de fato, e não como sociedades de afeto. Era grande a dificuldade em admitir que a convivência centrava-se na afetividade. Afastada a natureza familiar da união, os alimentos, e a pretensão sucessória eram rejeitados sob a alegação de impossibilidade jurídica do pedido. Modificando-se o entendimento, alguns julgados faziam aplicação da analogia à união estável heteroafetiva com fulcro nos princípios constitucionais da dignidade da pessoa humana e da igualdade. Finalmente o Supremo Tribunal Federal, em 05/05/2011, ao julgar a ADI $n^{\circ} 4.277 / \mathrm{DF}$ e a $\mathrm{ADPF} \mathrm{n}^{\circ}$ 132/RJ, reconheceu a união homoafetiva como entidade familiar. Ao interpretar o artigo 1.723 do Código Civil, conforme a Constituição Federal, garantiu aos parceiros homossexuais os mesmos direitos e deveres da união estável, entendida esta como sinônimo de família. A histórica decisão, ao atribuir efeitos pessoais e familiares às relações entre pessoas do mesmo sexo, referendou a jurisprudência que, há uma década, vinha preenchendo o vazio da legislação infraconstitucional.

No entanto, o tema carece de uma legislação específica. 
Seguimos, então, com a evolução histórica do instituto da união estável no direito brasileiro.

\subsection{Evolução da união estável no direito brasileiro}

\subsubsection{Concubinato}

O professor Álvaro Villaça Azevedo analisando a legislação anterior ao Código Civil de 1916, assegura que as leis, com relação ao instituto do concubinato, se referiam apenas para aplicação de sanções aos atos derivados deste instituto. Ao examinar o artigo 147 da Consolidação das Leis Civis de Teixeira de Freitas, percebe que ele possibilita à mulher casada, independentemente de autorização do marido, reivindicar bens móveis ou imóveis, que tenham sido doados ou transferidos por este à sua concubina. Também são anuláveis as doações feitas pelo marido a qualquer outra mulher, com quem tenha tido "afeição carnal”. Registre-se que ditos preceitos já se encontravam no título 66 do art. $4^{\circ}$ Livro das Ordenações Filipinas.

O Código Civil de 1916 não regulamentou o concubinato, não o proibiu, porém a este instituto se refere, sempre, procurando defender o instituto do casamento ou reproduzindo sanções da antiga legislação. Logo, o artigo 248, em seu inciso IV e seu parágrafo único, dá a possibilidade à mulher casada de, livremente, reivindicar os bens comuns, móveis ou imóveis, doados ou transferidos por seu marido à concubina. Tal direito da mulher existe, independentemente de estar ela, ou não, em companhia de seu marido e, ainda, que a doação esteja dissimulada em venda ou em outro contrato. Semelhante ao preceituado no direito anterior, o texto, do artigo sob análise, fora acrescido da palavra "comuns" adjetivando o vocábulo "bens", passando a ideia de que, se a alienação à concubina for de bem próprio do marido, de nada poderá reclamar a mulher, quanto a essa alienação, ocorrendo, por isso, neste ponto, o acolhimento do efeito translativo do domínio da coisa, no regime do concubinato adulterino. ${ }^{215}$

Tal disposição ainda permanece no Código Civil de 2002 em seu artigo 1.642, inciso $\mathrm{V}$ o qual assegura que:

${ }^{215}$ AZEVEDO, Álvaro Villaça. Do Concubinato ao Casamento de Fato. 2 ed. Belém: CEJUP, 1987, p. 6873. 
Qualquer que seja o regime de bens, tanto o marido quanto a mulher podem livremente: v- reivindicar os bens comuns, móveis ou imóveis, doados ou transferidos pelo outro cônjuge ao concubino, desde que provado que os bens não foram adquiridos pelo esforço comum destes, se o casal estiver separado de fato por mais de 5 (cinco) anos.

A longa e difusa prática do concubinato no Brasil gerou inúmeras questões legais, principalmente como relação à divisão do patrimônio após o fim do relacionamento entre as partes. Como o legislador brasileiro negou o reconhecimento de quaisquer direitos patrimoniais às uniões livres, os tribunais brasileiros tiveram que adotar uma postura diferente com relação às consequências jurídicas das relações concubinárias. Ao procurar garantir proteção mínima a essas uniões, os tribunais se utilizaram de duas estratégias para garantir uma divisão de bens equitativa entre os concubinos após o fim do relacionamento: a compensação financeira por serviços domésticos e a classificação do concubinato como sociedade de fato. ${ }^{216}$

\subsubsection{Concubinato como sociedade de fato}

O professor Álvaro Villaça Azevedo, citando o professor Sílvio Rodrigues assegura que: se a Jurisprudência já negou qualquer efeito jurídico ao concubinato, certo é que, em reparação a essa injustiça, surgiram duas soluções, em seu benefício: uma, atribuindo à companheira, que prestou, por muito tempo, serviços domésticos ao concubino direito a salários; outra, conferindo participação no patrimônio adquirido pelo esforço comum, dada a sociedade de fato entre os concubinos. Tal entendimento redundou na Súmula n ${ }^{\circ} 380$ do Supremo Tribunal Federal, baseada em quase uma dezena de julgados, de 1946 a 1963, com o seguinte teor: "Comprovada a existência de sociedade de fato entre os concubinos, é cabível a sua dissolução judicial com a partilha do patrimônio adquirido pelo esforço comum".

Assim, entendiam os Tribunais que "o simples concubinato não gera direitos ao patrimônio do companheiro", sendo necessária prova de formação da sociedade de fato, com a efetiva colaboração dos concubinos, para a realização de seu patrimônio comum.

${ }^{216}$ MOREIRA, Adilson José. União Homoafetiva. A Construção da Igualdade na Jurisprudência Brasileira. 2 ed. revista e atualizada. Curitiba: Juruá, 2012, p. 70. 
Apesar de toda a jurisprudência o professor Álvaro Villaça Azevedo entendia que:

Em um concubinato puro, basta a convivência concubinária, para que já se admita o condomínio, nascido do esforço comum dos concubinos, pois não se uniram eles sob mera sociedade de fato, em qualquer empresa, mas com o intuito de constituírem sua família, com um atestado societário mais forte, que deve merecer todo o apoio e toda a proteção do Estado, por seus poderes constituídos. Esse entendimento também encontra respaldo na Jurisprudência, mas repita-se, em concubinato que não afronte a família legítima. ${ }^{217}$

Importante destacar a ementa de decisório do Tribunal de Justiça do Estado de São Paulo, em que foi relator o Desembargador Paulo Otaviano: "É suficiente a permanência da concubina no lar, nas lides domésticas, para se lhe reconhecer o direito em parte do patrimônio formado pelo companheiro" (RT 401/193).

Porém, quando o concubinato é adulterino, a Jurisprudência tem sido severa em inadmitir efeitos jurídicos válidos ao adultério (RT 507/234; 458/224; 423/126). De acordo com o julgado do Tribunal de Justiça do Estado da Guanabara, de 1962, sendo relator o Desembargador Manoel Antônio de Castro Cerqueira, salienta:

Resultando o concubinato de adultério, que a lei repele como crime, não pode ter efeitos de natureza patrimonial e, não provada a participação direta e efetiva da mulher na formação do patrimônio do concubino, casado e com filhos, não tem a concubina direito à meação dos bens do companheiro falecido, pertencente ao casal. ${ }^{218}$

\subsubsection{Legislação extravagante em defesa do concubinato}

Leciona o professor Álvaro Villaça Azevedo que com o crescente número de desajustamentos conjugais aumentaram os casos de desquites, com a consequente impossibilidade de novas uniões legítimas, até que se editasse em 26 de dezembro de 1977 , A Lei $n^{\circ} 6.515$, chamada Lei do divórcio.

Assim, foi importante o surgimento de uma legislação extravagante, em defesa do concubinato, e de uma jurisprudência, em evolução constante, nesse mesmo sentido, de

\footnotetext{
${ }^{217}$ AZEVEDO. Álvaro Villaça. Do Concubinato ao Casamento de Fato. 2 ed. Belém: CEJUP, 1987, p. 75, 82-87.

${ }^{218}$ AZEVEDO, Álvaro Villaça. Do Concubinato ao Casamento de Fato. 2 ed. Belém: CEJUP, 1987, p. 8889.
} 
caráter jurídico, mas de cunho eminentemente social. Cita, então, o professor Villaça algumas leis importantes na defesa dos direitos dos concubinos:

O Decreto-Lei $\mathrm{n}^{\mathrm{o}}$ 7.036, de 10 de novembro de 1944, conhecido por Lei de Acidentes do Trabalho, que estabeleceu em seu parágrafo único do artigo 21, que a companheira mantida pela vítima tem os mesmos direitos do cônjuge legítimo, caso este não exista ou não tenha direito ao benefício, desde que tenha sido mencionada como beneficiária em qualquer ato solene, como, por exemplo, na carteira profissional ou no livro de registro de empregados. Em 19 de outubro de 1976, houve a Lei $n^{\circ}$ 6.367, que dispôs sobre seguro de acidentes de trabalho, fortalecendo, mais a situação da companheira com seu Decreto regulador $\mathrm{n}^{\circ} 79.037$ de 24 de dezembro de 1976. A matéria foi sumulada sob o número 35 em nosso Supremo Tribunal Federal, e nos seguintes termos: "Em caso de acidente do trabalho ou de transporte, a concubina tem direito de ser indenizada pela morte do amásio, se entre eles não havia impedimento para o matrimônio”. Vê-se a exigência de que tal benefício só exista à concubina, se sua convivência concubinária for pura, não adulterina, nem incestuosa.

Outra lei que atribui benefícios ao concubinato puro foi a Lei $\mathrm{n}^{\circ} 4.242$, de 17 de julho de 1963 a qual admitiu em seu artigo 44 que possa o contribuinte separado judicialmente, sem obrigação de sustentar sua ex-mulher, abater, em sua declaração de imposto sobre a renda, os encargos de família de sua concubina, desde que com ela conviva por mais de cinco anos e que a tenha incluído como sua beneficiária, sendo necessário que entre esses mesmos concubinos exista impedimento legal ao casamento, nos moldes do artigo $3^{\circ}$ da Lei $n^{\circ} 4.862$, de 29 de novembro de 1965.

É importante também destacar, a Lei no 4.609, de 11 de junho de 1962, que, pelos parágrafos $3^{\circ}$ e $4^{\circ}$ de seu artigo $5^{\circ}$, autoriza o servidor civil, militar ou autárquico, solteiro, separado judicialmente, viúvo, a destinar a pensão à sua concubina, desde que com ela conviva há mais de cinco anos e subsista impedimento legal ao casamento; e isto, se esse servidor não tiver filhos capazes de receber esse benefício, pois, neste caso, só poderá destiná-la metade da referida pensão.

Também importante foi a possibilidade de continuar a locação de imóvel residencial pela concubina, ante a morte de seu companheiro, locatário, já o proclama a Lei $n^{\circ} 4.494$ de 25 de novembro de 1964, em seu artigo 9. Porém, a Lei do Inquilinato não 
pode estender seu manto protetor ao concubinato impuro (adulterino), pois o legislador pátrio não pode emprestar efeitos jurídicos benéficos ao adultério, que se considera ilícito civil e até penal em nosso Direito positivo. ${ }^{219}$

\subsection{União estável}

Toda esta linha de entendimentos gerou o reconhecimento da comunidade formada pelos concubinos e pela sua prole como uma entidade familiar que merece proteção legal.

Ensina o professor Álvaro Villaça Azevedo que existem duas espécies de concubinato: o puro e o impuro e desleal. "É puro o concubinato quando se constitui a família de fato, sem qualquer detrimento da família legítima ou de outra família de fato". "Impuro é o concubinato, se for adulterino, incestuoso ou desleal, como, respectivamente, o de um homem casado, que mantenha, paralelamente ao seu lar, outro de fato; o de um pai com sua filha; e o de um concubino formando um outro concubinato." Quanto ao concubinato puro ou união estável, este deve merecer completa proteção, diferentemente do que deve suceder com o concubinato impuro ao qual deve ser aplicada a Súmula 380 do Supremo Tribunal Federal, atualmente revogada em parte. ${ }^{220}$

A Constituição de 1988 , por meio do seu $\S 3^{\circ}$, de seu artigo 226 , reconheceu o concubinato puro como forma de constituição de família, substituindo a palavra concubinato pela expressão união estável.

Analisando a Lei $\mathrm{n}^{\circ}$ 8.971/94, primeira regulamentação da união estável, o professor Álvaro Villaça Azevedo nos ensina que tal lei regulou o direito dos companheiros aos alimentos e à sucessão. Desse modo, concedendo direito aos alimentos aos conviventes, reconheceu a lei os mesmos direitos e deveres existentes entre cônjuges constantes da Lei de Alimentos, $n^{\circ}$ 5.478, de 1968. Porém, esse direito-dever alimentar surgia apenas após o decurso do prazo de cinco anos ou o nascimento de filho. Porém, esse art. $1^{\circ}$ não previa a hipótese de mau comportamento do convivente alimentando, como previsão de perda da pensão alimentícia.

\footnotetext{
${ }^{219}$ AZEVEDO. Álvaro Villaça. Do Concubinato ao Casamento de Fato. 2 ed. Belém: CEJUP, 1987, p. 7580.

${ }^{220}$ AZEVEDO, Álvaro Villaça. Direito de Família. Curso de Direito Civil. São Paulo: Atlas, 2013, p. 137.
} 
Quanto ao direito sucessório, o artigo $2^{\circ}$ da Lei $\mathrm{n}^{\circ}$ 8.971/94 nos dois primeiros incisos reeditavam o preceituado no $\S 1^{\circ}$ do artigo 1.611 do Código Civil de 1916, que tratava do cônjuge viúvo que era casado sob regime de bens diverso do da comunhão universal, para o qual era assegurado o usufruto vidual. O professor Álvaro Villaça Azevedo sempre entendeu não conveniente essa reafirmação para os conviventes do direito ao usufruto, pois na prática, atrapalhava o direito dos herdeiros, sendo melhor tornar o convivente sobrevivo herdeiro, adquirindo sua parte na herança em concorrência com os filhos. No Código Civil atual, o usufruto vidual foi substituído integralmente pela concessão de cota-parte da herança ao cônjuge sobrevivo. Quanto à sucessão do companheiro (a) esta vem regulada pelo artigo 1.790 do atual Código Civil. ${ }^{221}$

Em análise da Lei nº 9.278/96, segunda regulamentação da união estável, o professor Álvaro Villaça Azevedo nos ensina que esta lei regulamentou o $§ 3^{\circ}$ do art. 226 da Constituição Federal, de 5 de outubro de 1988, e reconheceu em seu artigo $1^{\circ}$ como entidade familiar a convivência duradoura, pública e contínua, de um homem e de uma mulher, estabelecida com objetivo de constituição de família.

A lei em comento foi fundamentada no esboço de Anteprojeto de 1987, do professor Álvaro Villaça Azevedo e que deu um tratamento legislativo mais consistente à união estável, tanto que o artigo $1^{\circ}$ da Lei ${ }^{\circ}$ 9.278/96 vem reproduzido no artigo 1.723 do Código Civil, que regulamenta a união estável.

Com relação ao artigo $2^{\circ}$ dessa mesma lei, eram enumerados os direitos e deveres iguais dos conviventes, tais como o respeito e a consideração mútuos (inciso I), a assistência moral e material recíprocas (inciso II), e a guarda o sustento e a educação dos filhos comuns (inciso III).

$\mathrm{O}$ artigo $3^{\circ}$ foi vetado e referia-se ao contrato escrito de que podiam valer-se os conviventes para regular seus interesses, principalmente os de ordem patrimonial. Apesar do veto, não estão obstados os companheiros de programar o regime de seu patrimônio. Como a união estável é situação de fato, esse contrato escrito pode ser feito a qualquer tempo, diferentemente do casamento, em que o pacto deve ser anterior a este. Portanto, mesmo com o veto do artigo $3^{\circ}$, os conviventes não estavam impedidos de realizar contratos de convivência, haja vista ser admitida a existência de contrato escrito na parte final do caput do art. $5^{\circ}$, e de seu $\S 2^{\circ}$.

${ }^{221}$ AZEVEDO, Álvaro Villaça. Direito de Família. Curso de Direito Civil. São Paulo: Atlas, 2013, p. 145146. 
Também o artigo $4^{\circ}$ foi vetado. Esse artigo cuidava do registro do contrato de convivência no Cartório do Registro Civil da residência de qualquer dos conviventes, com comunicação ao Cartório de Registro de Imóveis, para averbação, nos casos em que integrassem a contratação bens imóveis de um ou de ambos os concubinos.

Com relação ao artigo $5^{\circ}$ este estabelece norma dispositiva no sentido de que, não havendo estipulação em contrato escrito, os bens móveis e imóveis, adquiridos, onerosamente, por um ou por ambos os concubinos, no período em que durar a união estável, são considerados fruto do trabalho e da colaboração comum, pertencendo a ambos, em condomínio e em partes iguais. No mesmo sentido é o artigo 1.725 do atual Código Civil. $\mathrm{O} \S 1^{\circ}$ do artigo $5^{\circ}$ estabelecia que a presunção do caput cessa caso a aquisição patrimonial ocorrer com o produto de bens adquiridos anteriormente ao início da união. Também o $\S 2^{\circ}$ prevê o contrato escrito para afastar a competência de ambos os conviventes para administrar o patrimônio comum dos conviventes.

O vetado artigo $6^{\circ}$ cuidava da dissolução da união estável, por vontade das partes, por morte de um dos conviventes, por rescisão ou por denúncia do contrato. Além disso, caso os conviventes tivessem firmado contrato escrito de convivência e averbado em Cartório, qualquer deles poderia requerer a averbação do acordo dissolutório da união estável $\left(\S 2^{\circ}\right)$. O $\S 3^{\circ}$ do mesmo artigo $6^{\circ}$ tratava da rescisão em caso de ruptura da união estável por violação dos deveres constantes dessa lei e do contrato escrito. Os deveres dos companheiros atualmente estão previstos no artigo 1.724 do atual Código Civil. O $\S 4^{\circ}$ do artigo vetado declarava que a denuncia do contrato concubinário, escrito ou verbal, ocorria pela simples separação de fato dos conviventes. O artigo $7^{\circ}$ tratava de prestação de assistência material, de caráter alimentar, em caso de dissolução por rescisão. Caso a união estável fosse dissolvida por morte de um dos conviventes (parágrafo único), o sobrevivente teria direito real de habitação do imóvel destinado à residência da família, enquanto vivesse ou não constituísse nova união ou casamento. $\mathrm{O}$ artigo $8^{\circ}$ atendia à exigência constitucional, prevista no $\S 3^{\circ}$ do artigo 226 , o qual determina que o legislador deverá facilitar a conversão da união estável em casamento. No mesmo sentido é o artigo 1.726 do atual Código Civil. O artigo $9^{\circ}$ deixava clara a competência do juízo da Vara de Família, com relação à matéria referente à união estável. ${ }^{222}$

${ }^{222}$ AZEVEDO, Álvaro Villaça. Direito de Família. Curso de Direito Civil. São Paulo: Atlas, 2013, p. 146153. 


\subsection{União homoafetiva e a jurisprudência brasileira}

De acordo com Adilson José Moreira, é possível distinguir três períodos no desenvolvimento da jurisprudência brasileira sobre as uniões entre pessoas do mesmo sexo.

O primeiro teve início em 1989 com algumas decisões pioneiras reconhecendo uniões homoafetivas como sociedades de fato. Apesar de possibilitar apenas o acesso a direito patrimoniais, esses acórdãos reconheceram, pela primeira vez, o fato de que os casais homossexuais merecem proteção jurídica.

O segundo período começou em 1996 com uma nova série de decisões garantindo direitos previdenciários aos casais homossexuais. Afirmando que essa categoria de indivíduos merece tratamento igualitário e referindo-se a sociedade de fato como uma forma de status semelhante às uniões heterossexuais, várias cortes brasileiras passaram a classificar uniões homossexuais como entidades familiares.

Dois fatores principais caracterizam o terceiro período da jurisprudência brasileira sobre as uniões homoafetivas: as decisões classificando essas uniões como uniões estáveis e as ações civis públicas estendendo direitos matrimoniais a casais homossexuais. ${ }^{223}$

A jurisprudência do concubinato estabeleceu princípios e regras de grande importância para o desenvolvimento da jurisprudência sobre as uniões homoafetivas. Todas essas decisões foram responsáveis pela consolidação da ideia de que o Estado deve proteger as famílias informais, princípio que terá grande importância no processo de reconhecimento dos casais homossexuais como entidades familiares. Os Tribunais também lançaram as bases para a rejeição do argumento de que a procriação é o objetivo central das uniões conjugais. Assim, o reconhecimento desses relacionamentos como sociedade de fato foi a primeira forma de proteção legal conferida aos casais homossexuais no Brasil, caracterizando o início da jurisprudência brasileira sobre as uniões entre pessoas do mesmo sexo. $^{224}$

\footnotetext{
${ }^{223}$ MOREIRA, Adilson José. União Homoafetiva. A Construção da Igualdade na Jurisprudência Brasileira. 2 ed. revista e atualizada. Curitiba: Juruá, 2012, p. 69.

${ }^{224}$ MOREIRA, Adilson José. União Homoafetiva. A Construção da Igualdade na Jurisprudência Brasileira. 2 ed. revista e atualizada. Curitiba: Juruá, 2012, p. 83.
} 
O reconhecimento de direitos às uniões homoafetivas teve que trilhar o mesmo caminho percorrido pelas uniões extramatrimoniais, quando não havia como negar a existência de tais relacionamentos, estes eram resolvidos pelo direito das Obrigações, como relações de caráter comercial, sendo julgadas pelas varas cíveis. Chamadas de sociedades de fato, repartia-se o patrimônio comprovadamente amealhado por esforço comum durante o período de convivência.

O processo de reconhecimento jurídico das uniões entre pessoas do mesmo sexo no Brasil teve início com uma série de ações de casais homossexuais solicitando o acesso aos direitos decorrentes das instituições que regulam as uniões livres.

O Tribunal de Justiça do Rio de Janeiro foi a primeira corte brasileira a reconhecer uma união homoafetiva como uma sociedade de fato.

De acordo com o professor Álvaro Villaça Azevedo, foi muito citada a decisão do juiz José Bahadian, da $28^{\mathrm{a}}$ Vara Cível da Comarca do Rio de Janeiro, na ação promovida contra o espólio de um artista plástico, que teve início em 17 de maio de 1988. O autor da ação argumentou que a união mantida com o seu ex-companheiro assemelhava-se às uniões concubinárias. Nesse processo foi reconhecido direito do companheiro sobrevivo à metade do patrimônio por eles amealhado, em razão do falecimento do outro, após dezessete anos de convivência. Patenteou-se, então, a existência de sociedade de fato entre os conviventes e de um patrimônio criado pelo esforço comum.

O direito à metade do patrimônio do companheiro falecido estava assegurado por testamento feito em 1985, posteriormente revogado por outro testamento, firmado pelo testador quando este já estava internado, em estado grave no Memorial Hospital de Nova Iorque, conforme atestaram algumas testemunhas, e que não estaria o mesmo na plena capacidade de entendimento dos fatos; tudo de acordo com ampla divulgação à época por meio da mídia.

Em grau de apelação, o Tribunal de Justiça do Rio de Janeiro, em 08 de agosto de 1989, Apelação Cível no 731/89, unanimemente, por sua $5^{\text {a }}$ Câmara Cível, sendo relator o Desembargador Narcizo A. Teixeira Pinto (RT 742/393), AC 731/89, decidiu que a divisão há de ser proporcional à contribuição de cada um, sendo-lhe reservado um quarto do patrimônio deixado pelo companheiro falecido. Leciona o professor Álvaro Villaça Azevedo que nesse julgado, foi reconhecida, tão somente, a sociedade de fato, e não união 
livre como entidade familiar. Ficou evidenciado neste acórdão que a mesma Câmara, em outra decisão, em que foi relator o desembargador José Carlos Barbosa Moreira, entendeu que:

"o benefício econômico não se configura apenas quando alguém aufere
rendimentos, senão igualmente quando deixa de fazer despesas que, de outra
maneira, teria de efetuar" (Apelação Cível 38.956/85). E assim deve ser, porque
o esforço comum, que caracteriza a sociedade de fato, pode ser representado por
qualquer forma de contribuição: pecuniária ou através da doação de bens
materiais ou ainda por meio de prestação de serviços. Este é, sem dúvida, o
sentido que o Código Civil brasileiro, ao definir o contrato de sociedade,
empresta à locução "combinar esforços ou recursos para lograr fins comuns"
(art. 1.363). Como é de primeira evidência, a expressão "esforços ou recursos"
abrange todas as formas ou modalidades de contribuições para um fim comum.
225

Em artigo publicado pela Revista da Faculdade de Direito, em 1999, sob o título "Uniões entre pessoas do mesmo sexo" o professor Álvaro Villaça Azevedo deixa claro que:

União estável inexistente. Do mesmo modo, ainda que se cogite de mera convivência, no plano fático, entre pessoas do mesmo sexo, não se configura a união estável.

Realmente, desde que foram considerados efeitos ao concubinato, até o advento da Súmula 380 do Supremo Tribunal Federal, sempre a jurisprudência brasileira teve em mira o par andrógino, o homem e a mulher.

Com a Constituição Federal, de 05 de outubro de 1988, ficou bem claro esse posicionamento, de só reconhecer, como entidade familiar, a união estável entre o homem e a mulher, conforme o claríssimo enunciado do $\S$ $3^{\circ}$ do seu art. 226."226

Data de 10 de fevereiro de 1998 a primeira decisão unânime do Superior Tribunal de Justiça, Recurso Especial No 148897/MG, de sua 4ª Turma, sendo Relator o Ministro Ruy Rosado de Aguiar, que, afirmando a existência de sociedade de fato, assegurou ao parceiro homossexual a metade do patrimônio adquirido pelo esforço comum.

EMENTA: SOCIEDADE DE FATO. Homossexuais. Partilha do bem comum. $\mathrm{O}$ parceiro tem o direito de receber a metade do patrimônio adquirido pelo esforço comum, reconhecida a existência de sociedade de fato com os requisitos previstos no art. 1363 do Código Civil. RESPONSABILIDADE CIVIL. Dano moral. Assistência ao doente com

\footnotetext{
${ }^{225}$ AZEVEDO. Álvaro Villaça. Unióes entre pessoas do mesmo sexo. Revista da Faculdade de Direito da USP. V. 94, 1999, p. 19-20.

${ }^{226}$ AZEVEDO. Álvaro Villaça. Uniões entre pessoas do mesmo sexo. Revista da Faculdade de Direito da USP. V. 94, 1999, p. 19.
} 
Aids. Improcedência da pretensão de receber do pai do parceiro que morreu com Aids a indenização pelo dano moral de ter suportado sozinho os encargos que resultaram da doença. Dano que resultou da opção de vida assumida pelo autor e não da omissão do parente, faltando o nexo de causalidade. Art. 159 do Código Civil. AÇÃO POSSESSÓRIA julgada improcedente. Demais questões prejudicadas. Recurso conhecido em parte e provido.

Em seu voto o Min. Ruy Rosado observa que:

Tratando-se de união heterossexual, a jurisprudência tem reconhecido o direito de a companheira - que contribuiu, seja com a renda do seu trabalho produtivo ou como fornecimento de recursos próprios, seja mediante a prestação de serviços domésticos- receber parte do patrimônio que se formou graças a essa conjugação de esforços, destinados a garantir uma situação econômica estável.

Enfatiza ainda que:

A criação pretoriana inscrita no verbete de $n^{\circ} 380$ da Súmula do STF tem por referência os arts. 1363 e 1366 do CC; os efeitos patrimoniais ali descritos decorrem do direto das obrigações. .227

E arremata dizendo que:

Foi só mais tarde, com a evolução do direito de família, especialmente após a Constituição de 1988, que o tema passou a ser tratado como uma questão familiar.

Enfatiza, ainda, que:

O comportamento sexual deles pode não estar de acordo com a moral vigente, mas a sociedade civil entre eles resultou de um ato lícito, a reunião de recursos não está vedada na lei e a formação do patrimônio comum é consequência daquela sociedade. Na sua dissolução, cumpre partilhar os bens. $^{228}$

Comentando tal decisão, o professor Álvaro Villaça Azevedo deixa claro que:

Registre-se, neste ponto, a celeuma em torno de uma decisão unânime do Superior Tribunal de Justiça, de sua $4^{\text {a }}$ Turma, sendo relator o ministro Ruy Rosado de Aguiar, que, na verdade, não atribuiu direito de herança a homossexual, mas reconheceu direito à partilha de bens adquiridos, pelos parceiros, em decorrência de sua colaboração comum.

Como solução o professor Álvaro Villaça Azevedo recomenda:

\footnotetext{
${ }^{227}$ Súmula no 380 do STF. Comprovada a existência de sociedade de fato entre os concubinos, é cabível a sua dissolução judicial, com a partilha do patrimônio adquirido pelo esforço comum. Art. 1363, CC. Celebram contrato de sociedade as pessoas que mutuamente se obrigam a combinar seus esforços ou recursos, para lograr fins comuns. Art. 1366, CC. Nas questões entre os sócios, a sociedade só se provará por escrito; mas os estranhos poderão prova-la de qualquer modo.

228 REsp $\quad \mathrm{N}^{\circ}$ 148897-MG-Voto. Disponível em: http://w2stj.jus.br/processo/ita/documento/?num_registro=199700661245\&dt_publi. Acesso em 17 nov. 2013.
} 
Enquanto a união homossexual não for reconhecida como apta à constituição de família, o que nos parece prematuro, os parceiros devem acautelar-se com a realização de contratos escritos, que esclareçam a respeito de seu patrimônio, principalmente demonstrando os bens que existem, ou venham a existir, em regime de condomínio, com os percentuais estabelecidos ou-não. Se for o caso, para que não esbarrem suas convenções no direito sucessório de seus herdeiros, devem realizar testamentos esclarecedores de suas verdadeiras intenções. Podem, ainda, os parceiros adquirir bens em nome de ambos, o que importa condomínio, em partes iguais. ${ }^{229}$

No ano de 1999, o TJRS definiu a competência dos juizados especializados da família para apreciar as uniões de pessoas do mesmo sexo. ${ }^{230}$

RELAÇÕES HOMOSSEXUAIS. COMPETÊNCIA PARA
JULGAMENTO DE SEPARAÇÃO DE SOCIEDADE DE FATO DOS
CASAIS FORMADOS POR PESSOAS DO MESMO SEXO. Em se
tratando de situações que envolvem relações de afeto, mostra-se
competente para o julgamento da causa uma das varas de família, a
semelhança das separações ocorridas entre casais heterossexuais. Agravo
provido. (TJRS, AI 599075496, $\mathbf{8}^{\text {a }}$ C. Cível, Rel. Breno Moreira
Mussi, j. 17/06/1999).

De acordo com Maria Berenice Dias, o deslocamento das ações das varas cíveis para as varas de família provocou a remessa de todas as demandas que tramitavam nas varas cíveis para as varas de família, assim como os recursos foram encaminhados para as câmaras que detêm competência para apreciar tal matéria. Esse foi o primeiro grande marco que mudou os rumos da jurisprudência. ${ }^{231}$

Sobre a possibilidade de reconhecimento da união homossexual como entidade familiar, é paradigmática a decisão proferida pela $7^{a}$ Câmara Cível do Tribunal gaúcho na Apelação Cível $\mathbf{N}^{\mathbf{7}} \mathbf{7 0 0 0 1 3 8 8 9 8 2}$, relatada pelo Desembargador José Carlos Teixeira Giorgis e julgada em 14.03.2001, que teve a seguinte ementa:

EMENTA: UNIÃO HOMOSSEXUAL. RECONHECIMENTO. PARTILHA DO PATRIMÔNIO. MEAÇÃO. PARADIGMA. Não se permite mais o farisaísmo de desconhecer a existência de uniões entre pessoas do mesmo sexo e a produção de efeitos jurídicos derivados dessas relações homoafetivas. Embora permeadas de preconceitos, são realidades que o Judiciário não pode ignorar, mesmo em sua natural atividade retardatária. Nelas remanescem consequências semelhantes às

\footnotetext{
${ }^{229}$ AZEVEDO. Álvaro Villaça. Uniões entre pessoas do mesmo sexo. Revista da Faculdade de Direito da USP. V. 94, 1999, p. 21-22.

230 TJRS, AI599075496, 8ª Câm. Cível, Rel. Des. Breno Moreira Mussi, j. 17.06.1999 Disponível em: http://www.direitohomoafetivo.com.br. Acesso em 17 nov. 2013.

${ }^{231}$ DIAS, Maria Berenice. Diversidade Sexual e Direito Homoafetivo. 2 tiragem. São Paulo: Revista dos Tribunais, 2011, p. 252.
} 
que vigoram nas relações de afeto, buscando-se sempre aplicação da analogia e dos princípios gerais de direito, relevado sempre os princípios constitucionais da dignidade da pessoa humana e da igualdade. Desta forma, o patrimônio havido na constância do relacionamento deve ser partilhado como na união estável, paradigma supletivo onde se debruça a melhor hermenêutica. Apelação provida, em parte, por maioria, para assegurar a divisão do acervo entre os parceiros. (Apelação Cível $\mathrm{N}^{\circ}$ 70001388982, Sétima Câmara Cível, Tribunal de Justiça do RS, Relator: José Carlos Teixeira Giorgis, julgado em 14/03/2001). ${ }^{232}$

Quanto aos reflexos jurídicos das uniões homossexuais, Rainer Czajkowski em seu livro "União Livre", 2002, assegura que:

Por mais estável que seja, a união sexual entre pessoas do mesmo sexo que morem juntas ou não - jamais se caracteriza como entidade familiar. A não configuração de família, nestes casos, é resultante não de uma análise sobre a realização afetiva e psicológica dos parceiros, mas sim da constatação de que duas pessoas do mesmo sexo, não formam um núcleo de procriação humana e de educação de futuros cidadãos. ${ }^{233}$

No Estado da Bahia, o Tribunal entendeu ser possível a aplicação analógica da Lei

9.278/96 à recorrente e sua companheira:

TJBA, AC 16313-9/99, $3^{\text {a }}$ C.Cível, Rel. Des. Mário Albiani, j. 04/04/2001.

Ação de reconhecimento de dissolução de sociedade de fato cumulada com partilha. Demanda julgada procedente. Recurso improvido. Aplicando-se analogicamente a Lei 9.278/96, a recorrente e sua companheira têm direito assegurado de partilhar os bens adquiridos durante a convivência, ainda que se tratando de pessoas do mesmo sexo, desde que dissolvida a união estável. O Judiciário não deve distanciar-se de questões pulsantes, revestidas de preconceitos só porque desprovidas de norma legal. A relação homossexual deve ter a mesma atenção dispensada às outras relações. Comprovado o esforço comum para a ampliação ao patrimônio das conviventes, os bens devem ser partilhados. Recurso improvido. ${ }^{234}$

Entendimento de que a relação fática entre duas mulheres constitui união estável:

TJRS - Apelação Cível, No 70005488812, Sétima Câmara Cível, Relator José Carlos Teixeira Giorgis. Julgado em 25/06/2003.

Ementa: RELAÇÃO HOMOERÓTICA. UNIÃO ESTÁVEL. APLICAÇÃO DOS PRINCÍPIOS CONSTITUCIONAIS DA DIGNIDADE HUMANA E DA IGUALDADE. ANALOGIA.

$232 \quad$ Apelação Cível $\quad \mathrm{N}^{\mathrm{o}} \quad 70001388982 . \quad$ Disponível em: http://www.tjrs.jus.br/busca/search?q=proxystylesheet=tjrs_index\&getfields=*\&entsp=a_politica. Acesso em 02 dez. 2013.

${ }^{233}$ CZAJKOWSKI, Rainer. União Livre. À luz da Lei 8.971/94 e da Lei 9.278/96. 2 ed., revista e ampliada. Curitiba: Juruá, 2002, p. 222.

${ }^{234}$ TJBA, AC 16313-9/99, $3^{\text {a }}$ C.Cível. Disponível em http://www.direitohomoafetivo.com.br. Acesso em 05 jul. 2015 . 
PRINCÍPIOS GERAIS DO DIREITO. VISÃO ABRANGENTE DAS ENTIDADES FAMILIARES. REGRAS DE INCLUSÃO. PARTILHA DE BENS. REGIME DA COMUNHÃO PARCIAL. INTELIGÊNCIA DOS ARTIGOS 1.723, 1.725 E 1.658 DO CÓDIGO CIVIL DE 2002. PRECEDENTES JURISPRUDENCIAIS. Constitui união estável a relação fática entre duas mulheres, configurada na convivência pública, contínua, duradoura e estabelecida com o objetivo de constituir verdadeira família, observados os deveres de lealdade, respeito e mútua assistência. Superados os preconceitos que afetam ditas realidade, aplicam-se os princípios constitucionais da dignidade da pessoa, da igualdade, além da analogia e dos princípios gerais do direito, além da contemporânea modelagem das entidades familiares em sistema aberto argamassado em regras de inclusão. Assim, definida a natureza do convívio, opera-se a partilha dos bens segundo o regime da comunhão parcial. Apelações desprovidas. ${ }^{235}$

Reconhecimento da união homoafetiva tendo em vista os princípios da dignidade da pessoa humana e da igualdade:

TJRS, Apelação Cível No 70009550070, Sétima Câmara Cível, Relatora: Maria Berenice Dias, julgamento em: 17/11/2004.

Ementa: APELAÇÃO CÍVEL. UNIÃO HOMOAFETIVA. RECONHECIMENTO. PRINCÍPIO DA DIGNIDADE DA PESSOA HUMANA E DA IGUALDADE. É de ser reconhecida judicialmente a união homoafetiva mantida entre dois homens de forma pública e ininterrupta pelo período de nove anos. A homossexualidade é um fato social que se perpetuou através dos séculos, não podendo o judiciário se olvidar de prestar a tutela jurisdicional a uniões que, enlaçadas pelo afeto, assumem feição de família. A união pelo amor é que caracteriza a entidade familiar e não apenas a diversidade de gêneros. E, antes disso, é o afeto a mais pura exteriorização do ser e do viver, de forma que a marginalização das relações mantidas entre pessoas do mesmo sexo constitui forma de privação do direito à vida, bem como viola os princípios da dignidade da pessoa humana e da igualdade. AUSÊNCIA DE REGRAMENTO ESPECÍFICO. UTILIZAÇÃOO DE ANLOGIA E DOS PRINCÍPIOS GERAIS DE DIREITO. A ausência de lei específica sobre o tema não implica ausência de direito, pois existem mecanismos para suprir as lacunas legais, aplicando-se aos casos concretos a analogia, os costumes e os princípios gerais de direito, em consonância com os preceitos constitucionais (art. $4^{\circ}$ da LICC). ${ }^{236}$

A analogia entre a união estável e as uniões homoafetivas foi usada não apenas para reconhecer direitos daí decorrentes, mas também para ressaltar deveres jurídicos, tal como se observa no REsp 24.564, do Tribunal Superior Eleitoral, relatoria do Ministro Gilmar Mendes, julgado em 01/10/2004, em que reconheceu a relação homoafetiva, a fim

\footnotetext{
235 Apelação Cível $\quad N^{\circ} \quad 70005488812 . \quad$ Disponível em: http://www.tjrs.jus.br/busca/search?proxystylesheet=tjrs_index\&client=tjrs_index\&filter=0\&getfield Acesso em 05 jun. 2015.

${ }^{236}$ Apelação Cível No 70009550070. Disponível em: http://www.tjrs.br/busca/search?q-\&entsp=a_politica$\underline{\text { site } \& w c=2008 w c \_m c=1 \& o e=U T F-\& \& i e}$. Acesso em 05 jun. 2015.
} 
de ser declarada a inelegibilidade reflexa de pré-candidata ao cargo de prefeito, que mantinha relação de convivência com a prefeita reeleita do Município de Viseu/PA:

\section{'REGISTRO DE CANDIDATO. CANDIDATA AO CARGO DE PREFEITO. RELAÇÃO ESTÁVEL HOMOSSEXUAL COM A PREFEITA REELEITA DO MUNICÍPIO. INELEGIBILIDADE. ART. $14, \S 7^{\circ}$, DA CONSTITUIÇÃO FEDERAL.}

Os sujeitos de uma relação estável homossexual, à semelhança do que ocorre com os de relação estável, de concubinato e de casamento, submetem-se à regra de inelegibilidade prevista no art. $14 \S 7^{\circ}$ da Constituição Federal.

Recurso a que se dá provimento."237

Entendimento de que a união estável para ser reconhecida como entidade familiar exige a convivência duradoura, pública e contínua de um homem e uma mulher, estabelecida com objetivo de constituição de família:

TJRS, Apelação Cível No 70009888017, Sétima Câmara Cível, Relator Sérgio Fernando de Vasconcellos Chaves, data julgamento: 27/04/2005.

Ementa: RELACIONAMENTO HOMOSSEXUAL. INEXISTÊNCIA DE UNIÃO ESTÁVEL. 1. A união estável para ser reconhecida como entidade familiar, exige a convivência duradoura, pública e contínua de um homem e uma mulher, estabelecida com o objetivo de constituição de família, inclusive com a possibilidade de sua conversão em casamento, o que não ocorre na espécie. 2. Não havendo sequer situação fática assemelhada a um casamento, sem que o par sequer tenha morado sob o mesmo teto, não há como reconhecer a pretendida união homossexual com o objetivo de estender-lhe os efeitos próprios de uma união estável. Recurso desprovido, por maioria. ${ }^{238}$

No sentido de que se revela manifestamente impossível a pretensão declaratória de existência de união estável entre duas pessoas do mesmo sexo:

TJMG Apelação Cível 1.0024.04.537121-8/002, Relator Des. Domingos Coelho, data do julgamento: 24/05/2006.

Ementa: Apelação Cível. Ação declaratória. União homoafetiva. Impossibilidade jurídica do pedido. Carência de ação. Sentença mantida. A impossibilidade jurídica do pedido ocorre quando a ordem jurídica não permite a tutela jurisdicional pretendida. Na esteira da jurisprudência deste Tribunal de Justiça, diante da norma expressa, contida no art. 226, § $3^{\circ}$, da Constituição da República, somente entidade familiar pode constituir união estável, através de relacionamento afetivo entre homem e

\footnotetext{
${ }^{237}$ RESPE 24.564, TSE. Disponível em: www.gilmarmendes.org.br/index.php?option...respe... Acesso em 11 jul. 2015.

${ }^{238}$ Apelação Cível No 70009888017. Disponível em: http://www.tjrs.br/busca/search?q-\&entsp=a_politica$\underline{\text { site } \& w c=2008 w c \_m c=1 \& o e=U T F-\& \& i e}$. Acesso em 05 jun. 2015.
} 
mulher. Revela-se manifestamente impossível a pretensão declaratória de existência de união estável entre duas pessoas do mesmo sexo. ${ }^{239}$

No campo do direito previdenciário, há muitas decisões amparando os parceiros das uniões homoafetivas. Interessante decisão (REsp 238.715/RS) dada pela Terceira Turma do Superior Tribunal de Justiça, de relatoria do Ministro Humberto Gomes de Barros, julgado em 07/03/2006.

EMENTA - PROCESSO CIVIL E CIVIL - PREQUESTIONAMENTO - AUSÊNCIA - SÚMULA 282/STF - UNIÃO HOMOFETIVA INSCRIÇÃO DE PARCEIRO EM PLANO DE ASSISTÊNCIA MÉDICA - PÓSSIBILIDADE - DIVERGÊNCIA JURISPRUDENCIAL NÃO-CONFIGURADA.

- Se o dispositivo legal supostamente violado não foi discutido na formação do acórdão, não se conhece do recurso especial, à mingua de prequestionamento.

- A relação homoafetiva gera direitos e, analogicamente à união estável, permite a inclusão do companheiro dependente em plano de assistência médica.

- O homossexual não é cidadão de segunda categoria. A opção ou condição sexual não diminui direitos e, muito menos, a dignidade da pessoa humana. (Grifamos).

- Para configuração da divergência jurisprudencial é necessário confronto analítico, para evidenciar semelhança e simetria entre os arestos confrontados. Simples transcrição de ementas não basta. ${ }^{240}$

Possibilidade jurídica do reconhecimento de união estável entre pessoas do mesmo sexo:

TJRS Apelação Cível N. 70016660383, Oitava Câmara Cível, Relator: Claudir Fidelis Faccenda, data do julgamento: 26/10/2006.

Ementa: AÇÃO DECLARATÓRIA. RECONHECIMENTO DE UNIÃO ESTÁVEL ENTRE PESSAOS DO MESMO SEXO. POSSIBILIDADE JURÍDICA. 1. Os princípios constitucionais da igualdade e da dignidade da pessoa humana, dentre outros, que retratam direitos e garantias fundamentais, se sobrepõem a quaisquer outras regras, inclusive à insculpida no artigo 226, § $3^{\circ}$, da Constituição Federal, que exige a diversidade de sexos para o reconhecimento da união estável. 2. Restando devidamente comprovada a existência, por mais de quatro anos, de relação de afeto entre as partes, numa convivência more uxória, pública e

\footnotetext{
239 Apelação Cível 1.0024.04.537121-8/002. Disponível em: http://www5.tjmg.jus.br/jurisprudencia/imprimirEspelho.do . Acesso em 10 nov. 2013.

$\begin{array}{lllll}240 & \text { REsp } & \mathrm{N}^{\circ} & \text { 238.715/RS. } & \text { Disponível }\end{array}$ http://www.stj.jus.br/SCON/jurisprudencia/doc.jsp?livre=Resp+238715\&\&b=ACOR\&p=true\&=\&l. Acesso em 05 jan. 2014.
} 
notória, com comunhão de vida e mútua assistência, deve ser mantida a sentença que reconheceu a união estável. ${ }^{241}$

O INSS, motivado pela Ação Civil Pública n 2000.71.00.009347-0, editou a Instrução Normativa 25, de 7 de junho de 2000, que estabelece os "procedimentos a serem adotados para a concessão de benefícios previdenciários ao companheiro ou companheira homossexual". $\mathrm{O}$ ato permite a concessão de pensão por morte ou auxílio-reclusão ao companheiro ou companheira homossexual. Já é clara a relevância dessa relação afetiva no Direito Previdenciário.

Em julgado do Tribunal de Justiça de Minas Gerais, datado de 22/05/2007, foi reconhecida a união homoafetiva em analogia com a união estável:

TJMG, Apelação Cível $\mathbf{N}^{\circ} \quad \mathbf{1 . 0 0 2 4 . 0 6 . 9 3 0 3 2 4 - 6 / 0 0 1}$, Relatora Desembargadora Heloisa Combat, data do julgamento: 22/05/2007.

Ementa: AÇÃO ORDINÁRIA - UNIÃO HOMOAFETIVA ANALOGIA COM A UNIÃO ESTÁVEL PROTEGIDA PELA CONSTITUIÇÃO FEDERAL - PRINCÍPIO DA IGUALDADE (NÃODISCRIMIANÇÃO) E DA DIGNIDADE DA PESSOA HUMANA RECONHECIMENTO DA RELAÇÃO DE DEPENDÊNCIA DE UM PARCEIRO EM RELAÇÃO AO OUTRO, PARA TODOS OS FINS DE DIREITO - REQUISITOS PREENCHIDOS - PEDIDO PROCEDENTE - À união homoafetiva, que preenche os requisitos da união estável entre casais heterossexuais, deve ser conferido o caráter de entidade familiar, impondo-se reconhecer os direitos decorrentes desse vínculo, sob pena de ofensa aos princípios da igualdade e da dignidade da pessoa humana. - $\mathrm{O}$ art. 226, da Constituição Federal não pode ser analisado, restritivamente, devendo observar-se os princípios constitucionais da igualdade e da dignidade da pessoa humana. Referido dispositivo, ao declarar a proteção do Estado à união estável entre o homem e a mulher, não pretendeu excluir dessa proteção a união homoafetiva, até porque, à época em que entrou em vigor a atual Carta Política, há quase 20 anos, não teve o legislador essa preocupação, o que cede espaço para a aplicação analógica da norma a situações atuais, antes não pensadas. A lacuna existente na legislação não pode servir como obstáculo para o reconhecimento de um direito. ${ }^{242}$

O reconhecimento da possibilidade jurídica da união estável homoafetiva por analogia é visto de forma clara na decisão do REsp $\mathbf{N}^{\mathbf{0}} \mathbf{8 2 0 . 4 7 5}-\mathbf{R J}$, dada pela Quarta

\footnotetext{
241 Apelação Cível N. 70016660383, TJRS. Disponível em: http://www.tjrs.jus.br/busca/search?q=70021637145\&proxystylesheet=tjrs index\&client=tjrs index\&. Acesso em 9 de jul. 2015.

242 Apelação $\quad$ Cível $\quad \mathrm{N}^{\mathrm{O}}$ 1.0024.06.930324-6/001. Disponível em: http://www5.tjmg.jus.br/jurisprudencia/pesquisaPalavrasEspelhoAcordao.do?palavras... Acesso em 11 jul. 2015.
} 
Turma do Superior Tribunal de Justiça, de relatoria do Min. Antônio de Pádua Ribeiro, julgado em 02/09/2008 ${ }^{243}$.

PROCESSO CIVIL. AÇÃO DECLARATÓRIA DE UNIÃO HOMOAFETIVA. PRINCÍPIO DA IDENTIDADE FÍSICA DO JUIZ. OFENSA NÃO CARACTERIZADA AO ARTIGO 132, DO CPC. POSSIBILIDADE JURÍDICA DO PEDIDO, ARTIGOS $1^{\circ}$ DA LEI 9.278/96 E 1.723 E 1.724 DO CÓDIGO CIVIL. ALEGAÇÃO DE LACUNA LEGISLATIVA. POSSIBILIDADE DE EMPREGO DA ANALOGIA COMO MÉTODO INTEGRATIVO.

A despeito da controvérsia em relação à matéria de fundo:

A despeito da controvérsia em relação à matéria de fundo, o fato é que, para a hipótese em apreço, onde se pretende a declaração de união homoafetiva, não existe vedação legal para o prosseguimento do feito.

Os dispositivos legais limitam-se a estabelecer a possibilidade de união estável entre homem e mulher, desde que preencham as condições impostas pela lei, quais seja, convivência pública, duradoura e contínua, sem, contudo, proibir a união entre dois homens ou duas mulheres. Poderia o legislador, caso desejasse, utilizar a expressão restritiva, de modo a impedir que a união entre pessoas de idêntico sexo ficasse definitivamente excluída da abrangência legal. Contudo, assim não procedeu.

É possível, portanto, que o magistrado de primeiro grau entenda existir lacuna legislativa, uma vez que a matéria, conquanto derive de situação fática conhecida de todos ainda não foi expressamente regulada.

Ao julgador é vedado eximir-se de prestar jurisdição sob o argumento de ausência de previsão legal. Admite-se, se for o caso, a integração mediante o uso da analogia, a fim de alcançar casos não expressamente contemplados, mas cuja essência coincida com outros tratados pelo legislador.

É também no sentido do reconhecimento da união homoafetiva por analogia à união estável o julgado do Tribunal de Justiça de Minas Gerais, de 25/11/2009:

TJMG Apelação Cível $\mathbf{N}^{\mathbf{0}}$ 1.0024.09.484555-9/001, Relator Desembargador Elias Camilo, $8^{a}$ Câmara Cível, julgado em 25/11/2009.

Ementa: DIREITO DE FAMÍLIA - AÇÃO DE RECONHECIMENTO DE UNIÃO HOMOAFETIVA - ART. 226, § $3^{\circ}$ DA CF/88 - UNIÃO ESTÁVEL - ANALOGIA - OBSERVÂNCIA DOS PRINCÍPIOS DA IGUALDADE E DA DIGNIDADE DA PESSOA HUMANA POSSIBILIDADE JURÍDICA DO PEDIDO - VERIFICAÇÃO. Inexistindo na legislação lei específica sobre a união homoafetiva e seus efeitos civis, não há que se falar em análise isolada e restritiva do art.

243 REsp $\quad \mathrm{N}^{\mathrm{o}}$ 820.475-RJ. Disponível em: http://www.stj.jus.br/SCON/jurisprudencia/doc.jsp?livre=820475\&\&b=ACOR\&p=\&l=10\&i= Acesso em 31 mai. 2011. 
226, $\S 3^{\circ}$ da $\mathrm{CF} / 88$, devendo-se utilizar, por analogia, o conceito de união estável disposto no art. 1.723 do Código Civil/2002, a ser aplicado em consonância com os princípios constitucionais da igualdade (art. $5^{\circ}$, caput, e inc. I da carta Magna) e da dignidade humana (art. $1^{\circ}$, inc. III, c/c art. $5^{\circ}$, inc. $\mathrm{X}$, todos da $\left.\mathrm{CF} / 88\right)^{244}$

Entendimento de que o reconhecimento da união homoafetiva é juridicamente possível:

TJSP Apelação Cível n. 1090913220088260006, $4^{\text {a }}$ Câmara de Direito Privado, Relator Des. Francisco Eduardo Loureiro, 24/02/2011.

Apelação. UNIÃO ESTÁVEL- Reconhecimento - União homoafetiva Pedido juridicamente possível - Inexistência de vedação legal Precedentes do Superior Tribunal de Justiça e Tribunal de Justiça de São Paulo - Imperioso o reconhecimento da união homoafetiva como espécie de união estável, a gerar os mesmos efeitos jurídicos que esta, desde que preenchidos os requisitos legais exigidos para tanto (convivência pública, contínua e duradoura, com ânimo de constituir família) - No caso concreto, conjunto probatório concludente, indicativo de convivência more uxório do casal - Documentos nos autos a evidenciar conta conjunta e convivência por muitos anos na mesma residência, adquirida, inclusive, por ambas as companheiras - Prova testemunhal demonstrou ainda que a autora e a falecida irmã da ré trabalhavam, viajavam e frequentavam reuniões sociais juntas, como um verdadeiro casal - Nítido propósito de constituição de família e de formação de uma unidade econômica e social - Correta a sentença que reconheceu a união estável, com todos os efeitos jurídicos daí decorrentes - Recurso improvido. ${ }^{245}$

\subsection{Supremo Tribunal Federal e o reconhecimento das uniões homoafetivas como entidade familiar}

Em sede administrativa, o Supremo Tribunal Federal, desde 2009, por meio da Resolução 380/2008 e Ato Deliberativo 27/2009²46, já havia admitido a inclusão dos companheiros de união homofetiva de seus servidores como dependentes do plano de saúde e benefícios sociais.

\footnotetext{
244 Apelação Cível 1.0024.09.484555-9/001. Disponível em: http://www5.tjmg.jus.br/jursirpudencia/imprimirEspelho.do Acesso em fev. 2011.

${ }^{245}$ Apelação Cível n. 1090913220088260006. Disponível em: http://esaj.tjsp.jus.br/resultadocompleta.do... Acesso em 11 jul. 2015.

${ }^{246}$ DIAS, Maria Berenice. União Homoafetiva. O preconceito \& a Justiça, $5^{\text {a }}$ ed. São Paulo: RT, 2011, p. 277-278.
} 
[...] Art. $1^{\circ}$ Pode ser reconhecido (a) como beneficiário (a) do STF-Med, na qualidade de dependente, o companheiro ou companheira de união homoafetiva estável.

Art. $2^{\circ}$ A inscrição, no STF-Med, de companheiro ou companheira de beneficiário titular que mantenha união homofetiva estável é condicionada à comprovação da existência dessa união mediante:

\section{$[\ldots]$}

Art. $3^{\circ}$ Para os fins de que trata este Ato Deliberativo, será reconhecido (a) como companheiro ou companheira de união homoafetiva estável apenas solteiro (a), viúvo (a), divorciado (a) e aquele (a) cujo casamento tenha sido anulado por sentença judicial transitada em julgado.

$[\ldots]$

Art. $5^{\circ}$ Faz cessar a condição de beneficiário do STF-Med, na qualidade de dependente, para os fins de que trata este Ato:

II - a dissolução da união homoafetiva;

Da mesma forma, o Conselho Nacional de Justiça assegura o direito de dependência econômica aos companheiros dos seus servidores, por meio da Resolução $39 / 2007^{247}$.

[...] Art. $2^{\circ}$ Podem ser reconhecidos como dependentes econômicos de servidor:

V- companheiro de união homoafetiva.

No ano de 2006, Ministro Celso de Mello, ao extinguir a ação direta de inconstitucionalidade, sinalizou que, para o reconhecimento das famílias homoafetivas, o caminho era a arguição de descumprimento de preceito fundamental.

União civil entre pessoas do mesmo sexo. Alta relevância social e jurídico-constitucional da questão pertinente às uniões homoafetivas. Pretendida qualificação de tais uniões como entidades familiares. Doutrina. Alegada inconstitucionalidade do art. $1^{\circ}$ da Lei 9.278/1996. Norma legal derrogada pela superveniência do art. 1.723 do novo Código Civil (2002), que não foi objeto de impugnação nesta sede de controle abstrato. Inviabilidade, por tal razão, da ação direta. Impossibilidade jurídica, de outro lado, de se proceder à fiscalização normativa abstrata de normas constitucionais originárias $\left(\mathrm{CF}\right.$, art. $226, \S 3^{\circ}$, no caso). Doutrina. Jurisprudência (STF). Necessidade, contudo, de se discutir o tema das uniões estáveis homoafetivas, inclusive para efeito de sua subsunção ao conceito de entidade familiar: matéria a ser veiculada em sede de ADPF (STF, ADI 3.300-MC, j. 03.02.2006, rel. Min. Celso de Mello).

${ }^{247}$ DIAS, Maria Berenice. União Homoafetiva. O preconceito \& a Justiça, $5^{\text {a }}$ ed. São Paulo: RT, 2011, p. 270. 
Assim, no ano de 2008, o Governador do Estado do Rio de Janeiro propôs Arguição de Descumprimento de Preceito Fundamental (ADPF 132), visando equiparar as uniões homoafetivas às uniões estáveis, para a aplicação do regime jurídico dos servidores públicos estaduais.

No ano seguinte, 2009, a Procuradoria Geral da República ingressou com Arguição de Descumprimento de Preceito Fundamental (ADPF 178), a qual foi recebida pelo Presidente do STF como Ação Direta de Inconstitucionalidade (ADI 4.277). O objeto da ação era semelhante ao da interposta pelo governador do Estado do Rio de Janeiro, mas a segunda era mais abrangente do que a primeira, pois visava reconhecer a união entre duas pessoas do mesmo sexo como entidade familiar, quando presentes os pressupostos da união estável entre homem e mulher, bem como a extensão dos direitos e deveres dos companheiros das uniões estáveis às uniões entre casais de mesmo sexo. ${ }^{248}$

Finalmente, o rompimento da invisibilidade das uniões homoafetivas foi a histórica decisão do Supremo Tribunal Federal, que em 5 de maio de 2011, no julgamento de duas ações: Arguição de Descumprimento de Preceito Fundamental (ADPF 132/RJ) e Ação Direta de Inconstitucionalidade (ADI 4277/DF), com relatoria do Min. Ayres Brito, em votação unânime, julgou procedente a ação, com eficácia erga omnes e efeito vinculante, para dar ao art. 1.723 do Código Civil interpretação conforme a Constituição para dele excluir qualquer significado que impeça o reconhecimento da união contínua, pública e duradoura entre pessoas do mesmo sexo como "entidade familiar", entendida esta como sinônimo perfeito de "família". Reconhecimento que é de ser feito segundo as mesmas regras e com as mesmas consequências da união estável heteroafetiva.

Em 05 de maio de 2011 houve o julgamento conjunto das duas demandas. O julgamento foi pela procedência das ações e votaram a favor dez Ministros: o Relator Carlos Ayres Britto, Ricardo Lewandowski, Carmen Lúcia, Marco Aurélio, Celso de Mello, Luiz Fux, Joaquim Barbosa, Gilmar Mendes, Ellen Gracie e Cezar Peluso. O Ministro José Antonio Dias Toffoli não votou em razão de impedimento, por ter dado parecer favorável à anulação das decisões do TJRJ, à época, pela Advocacia Geral da União. $^{249}$

\footnotetext{
${ }^{248}$ DIAS, Maria Berenice. União Homoafetiva. O preconceito \& a Justiça, $5^{\mathrm{a}}$ ed. São Paulo: RT, 2011, p. 202-203.

${ }^{249}$ AZEVEDO, Álvaro Villaça. União Homoafetiva. Revista Juris da FAAP-JURIS, ano III, 2011, p. 21.
} 
Enfim, o Poder Judiciário cumpriu com o seu papel de guardião dos princípios constitucionais que devem reger a sociedade, mesmo quando haja omissão do legislador e em decisão unânime, o Supremo Tribunal Federal exerceu o papel que lhe é conferido pela Constituição Federal.

Passemos então, de forma sucinta, aos votos dos julgadores.

O primeiro voto foi do Ministro Ayres Brito, na qualidade de Relator. Sobre o termo "homoafetividade", utilizado para identificar o vínculo de afeto e solidariedade entre os pares do mesmo sexo:

Ainda nesse ponto de partida da análise meritória da questão, calha anotar
que o termo "homoafetividade", aqui utilizado para identificar o vínculo
de afeto e solidariedade entre pares ou parceiros do mesmo sexo, não
constava dos dicionários da língua portuguesa. O vocábulo foi cunhado,
pela primeira vez, na obra "União Homossexual, o Preconceito e a
Justiça", de autoria da desembargadora aposentada e jurista Maria
Berenice Dias, consoante a seguinte passagem: "Há palavras que
carregam o estigma do preconceito. Assim o afeto a pessoa do mesmo
sexo chamava-se "homossexualismo". Reconhecida a inconveniência do
sufixo "ismo", que está ligado à doença, passou-se a falar em
"homossexualidade", que sinaliza um determinado jeito de ser. Tal
mudança, no entanto, não foi suficiente para pôr fim ao repúdio social ao
amor entre iguais. (Homoafetividade: um novo substantivo).

O Ministro Carlos Ayres Brito fundamentou seu voto no art. $3^{\mathbf{o}}$, IV da

Constituição Federal, que proíbe toda forma de discriminação em virtude de sexo, raça, cor, idade, ou por quaisquer outras formas de discriminação.

Prossigo para ajuizar que esse primeiro trato normativo da matéria já antecipa que o sexo das pessoas, salvo expressa disposição constitucional em contrário, não se presta como fator de desigualação jurídica. É como dizer o que se tem no dispositivo constitucional aqui reproduzido em nota de rodapé (inciso IV, do artigo $3^{\circ}$ ) é a explícita vedação do tratamento discriminatório ou preconceituoso em razão do sexo dos seres humano. Tratamento discriminatório ou desigualitário sem causa que, se intentado pelo comum das pessoas ou pelo próprio Estado, passa a colidir frontalmente com o objetivo constitucional de "promover o bem de todos" (este o explícito objetivo que se lê no inciso em foco).

Quanto ao vocábulo "preconceito":

Mas é preciso lembrar que o substantivo "preconceito" foi grafado pela nossa Constituição com o sentido prosaico ou dicionarizado que ele porta; ou seja, preconceito é um conceito prévio. Uma formulação conceitual antecipada ou engendrada pela mente humana fechado em si mesma e por isso carente de apoio na realidade. Logo, juízo de valor não autorizado pela realidade, mas imposto a ela. 
Em tema do concreto uso do sexo:

Realmente, em tema do concreto uso do sexo nas três citadas funções de estimulação erótica, conjunção carnal e reprodução biológica, a Constituição brasileira opera por um intencional silêncio. Que já é um modo de atuar mediante o saque da kelseniana norma geral negativa, segundo a qual "tudo que não estiver juridicamente proibido, ou obrigado, está juridicamente permitido".

A preferência sexual se põe como direta emanação do princípio da "dignidade da pessoa humana" (inciso III do art. $1^{\circ}$ da $\mathrm{CF}$ ):

Óbvio que, nessa altaneira posição de direito fundamental e bem de personalidade, a preferência sexual se põe como direta emanação do princípio da "dignidade da pessoa humana" (inciso III do art. $1^{\circ}$ da CF), e, assim, poderoso fator de afirmação e elevação pessoal. De auto-estima no mais elevado ponto da consciência. Auto-estima, de sua parte, a aplainar o mais abrangente caminho da felicidade, tal como positivamente normada desde a primeira declaração norte-americana de direitos humanos (Declaração de Direitos do Estado da Virgínia, de 16 de junho de 1776) e até hoje perpassante das declarações constitucionais do gênero. Afinal, se as pessoas de preferência heterossexual só podem se realizar ou ser felizes heterossexualmente, as de preferência homossexual seguem na mesma toada: só podem se realizar ou ser felizes homossexualmente.

Com relação à família:

É desse anímico e cultural conceito de família que se orna a cabeça do art. 226 da Constituição. Donde a sua literal categorização como "base da sociedade". E assim, normada como figura central ou verdadeiro continente para tudo o mais, ela, família, é que deve servir de norte para a interpretação dos dispositivos em que o capítulo VII se desdobra, conforme transcrição feita. Não o inverso.

Ainda com relação à família:

A Constituição Federal não faz a menor diferenciação entre a família formalmente constituída e aquela existente ao rés dos fatos. Como também não distingue entre a família que se forma por sujeitos heteroafetivos e a que se constitui por pessoas de inclinação homoafetiva. Por isso que, sem nenhuma ginástica mental ou alquimia interpretativa, dá para compreender que a nossa Magna carta não emprestou ao substantivo "família" nenhum significado ortodoxo ou da própria técnica jurídica. Recolheu-o com o sentido coloquial praticamente aberto que sempre portou como realidade do mundo do ser.

Quanto ao conceito de família:

Assim, interpretando por forma não-reducionista o conceito de família, penso que este STF fará o que lhe compete: manter a Constituição na posse do seu fundamental atributo da coerência, pois o conceito contrário 
implicaria forçar o nosso Magno Texto a incorrer, ele mesmo, em discurso indisfarçadamente preconceituoso ou homofóbico.

A terminologia entidade familiar:

A terminologia "entidade familiar" não significa algo diferente de "família", pois não há hierarquia ou diferença de qualidade jurídica entre as duas formas de constituição de um novo núcleo doméstico.

Logo, diferentemente do casamento, ou da própria união estável, a família não se define como simples instituto ou figura de direito em sentido meramente objetivo. Essas duas objetivas figuras de direito que são o casamento civil e a união estável é que se distinguem mutuamente, mas o resultado a que chegam é idêntico: uma nova família, ou, se se prefere, uma nova "entidade familiar", seja a constituída por pares homoafetivos, seja a formada por casais heteroafetivos.

Tanto numa quanto noutra modalidade de legítima constituição da família, nenhuma referência é feita à interdição, ou à possibilidade, de protagonização por pessoas do mesmo sexo. Desde que preenchidas, também por evidente, as condições legalmente impostas aos casais heteroafetivos. Inteligência que se robustece com a proposição de que não se pró́be nada a ninguém senão em face de um direito ou de proteção de um interesse de outrem.

A heteroafetividade em si, não torna os indivíduos superiores em nada. Não os beneficia com a titularidade exclusiva do direito à constituição de uma família. Aqui, o reino é da igualdade pura e simples, pois não se pode alegar que os heteroafetivos perdem se os homoafetivos ganham.

Quanto à adoção, a Constituição Federal não abre distinção entre adotante "homo" ou "heteroafetivo". 250

O segundo ministro a votar foi o Ministro Luiz Fux.

Premissas sobre a homossexualidade:

A primeira delas é a seguinte: a homossexualidade é um fato da vida. A segunda premissa importante é a de que a homossexualidade é uma orientação e não uma opção sexual. A homossexualidade não constitui doença, desvio ou distúrbio mental, mas uma característica da personalidade do indivíduo. Sendo assim, não parece razoável imaginar que, mesmo no seio de uma sociedade ainda encharcada de preconceitos, tantas pessoas escolhessem voluntariamente um modo de vida descompassado as concepções morais da maior parte da coletividade, sujeitando-se à discriminação e, por vezes, ao ódio e à violência.

Quanto à origem da homossexualidade:

Independentemente da origem da homossexualidade - se de raiz genética, social, ambas ou quaisquer outras - tem-se, como certo que um

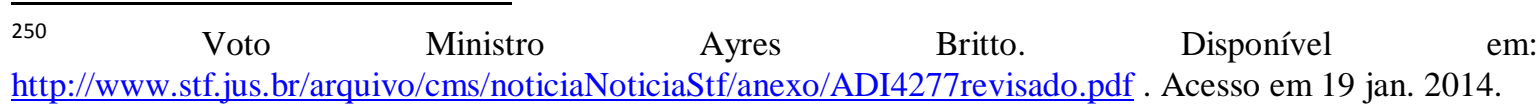


indivíduo é homossexual simplesmente porque o é. Na verdade, a única opção que o homossexual faz é pela publicidade ou pelo segredo das manifestações exteriores desse traço de sua personalidade.

Quanto às uniões homoafetivas:

De acordo com os primeiros resultados definitivos do censo 2010 do IBGE (disponíveis em http://www.ibge.gov.br; consulta em 30.04.2011), atualmente há mais de 60.000 (sessenta mil) uniões homoafetivas declaradas no Brasil, sendo perfeitamente presumível que muitas outras não tenham sido declaradas no último recenseamento populacional do país.

Vedação às uniões homoafetivas:

A quinta premissa não é fática, mas jurídica: não há qualquer inconstitucionalidade ou ilegalidade no estabelecimento de uniões homoafetivas. Não existe, no direito brasileiro, vedação às uniões homoafetivas, haja vista, sobretudo, a reserva de lei instituída pelo art. $5^{\circ}$, inciso II, da Constituição de 1988 para a vedação de quaisquer condutas aos indivíduos.

Poderia dizer-se, com algum cinismo, que se trata de "ato jurídico inexistente", vetusta e míope categorização, felizmente há muito abandonada. (É curioso recordar, aliás, que as clássicas lições do Direito Civil não raro mencionavam, como exemplo de "ato jurídico inexistente", o casamento entre pessoas do mesmo sexo...). Como já se sabia em Roma, ubi societas, ibi jus (onde está a sociedade, está o direito) - o direito segue a evolução social, estabelecendo normas para a disciplina dos fenômenos já postos. Não é diferente neste caso: o ato de constituição da união homoafetiva existe, ocorre e gera efeitos juridicamente relevantes, que, portanto, merecem tratamento pelo direito.

Quanto ao resultado deste julgamento:

Independentemente do resultado deste julgamento, a sua repercussão social será imensa e são, em boa parte, imprevisíveis as suas consequências. Mas assim será toda vez que as liberdades essenciais dos indivíduos - em especial aquelas ligadas à sua identidade - forem alvo de ameaças do Estado ou dos particulares e o Supremo Tribunal Federal, como guardião da Constituição, for convocado a assegurar a proteção aos direitos fundamentais.

Com relação ao preconceito:

Canetas de magistrados não são capazes de extinguir o preconceito, mas, num Estado Democrático de Direito, detêm o poder de determinar ao aparato estatal a atuação positiva na garantia da igualdade material entre os indivíduos e no combate ostensivo às discriminações odiosas.

O que distingue, do ponto de vista ontológico, as uniões estáveis, heteroafetivas, das uniões homoafetivas? 
Será impossível que duas pessoas do mesmo sexo não tenham entre si relação de afeto, suporte e assistência recíprocos? Que criem para si, em, comunhão, projetos de vida duradoura em comum? Que se identifique, para si e para terceiros, como integrantes de uma célula única, inexoravelmente ligados? A resposta a essas questões é uma só: $\underline{\text { Nada as }}$ distingue.

Nesse diapasão, a distinção entre as uniões heterossexuais e as uniões homossexuais não resiste ao teste da isonomia. Para tanto, recorde-se o magistério de Robert Alexy para que, inexistindo razão suficiente para o tratamento jurídico diferenciado, impõe-se o tratamento idêntico.

Considerações de ordem moral:

Não se pode ceder, no caso, a considerações de ordem moral, exceto por uma, que, ao revés, é indispensável: todos os indivíduos devem ser tratados com igual consideracãa e respeito. É esta a base da leitura moral da Constituição propugnada por Ronald Dworkin (Freedom's Law: The Moral Reading of The American Constitution).

Diante disso, ignorar a existência e a validade jurídica das uniões homoafetivas é o mesmo que as por em situação de injustificada desvantagem em relação às uniões estáveis heterossexuais.

Quanto ao silêncio legislativo:

O silêncio legislativo sobre as uniões homoafetivas nada mais é do que um juízo moral sobre a realização individual pela expressão de sua orientação sexual.

Resta claro, por conseguinte, que o desprezo das uniões homoafetivas é uma afronta à dignidade dos indivíduos homossexuais.

O silêncio normativo catalisa a clandestinidade das relações homoafetivas, na aparente ignorância de sua existência; a ausência de acolhida normativa, na verdade, significa rejeição.

Política de reconhecimento:

A aplicação da política de reconhecimento dos direitos dos parceiros homoafetivos é imperiosa, por admitir a diferença entre os indivíduos e trazer para a luz relações pessoais básicas de um segmento da sociedade que vive parte importantíssima de sua vida na sombra. Uma união estável homoafetiva, por si só, não tem o condão de lesar a ninguém, pelo que não se justifica qualquer restrição ou, como é ainda pior, a limitação velada, disfarçada de indiferença.

A questão do reconhecimento também toca o tema da segurança jurídica. $\mathrm{O}$ alheamento do direito positivo relativamente às uniões homoafetivas gera inaceitável insegurança para os indivíduos. Mesmo parceiros que vivem juntos por muitos anos não conseguem antecipar claramente como se dará a sucessão dos bens que amealharam juntos, precisando recorrer a disposições testamentárias e seus limites legais.

A previsão literal "entre homem e mulher": 
Saliente-se, ainda, que não se há de objetar que o art. 226, § $3^{\circ}$ constituiria obstáculo à equiparação das uniões homoafetivas às uniões estáveis heterossexuais, por força da previsão literal "entre homem $e$ mulher". Assiste razão aos proponentes das ações em exame em seus comentários à reação do referido dispositivo constitucional. A norma foi inserida no texto constitucional para tirar da sombra as uniões estáveis e inclúílas no conceito de família. Seria perverso conferir a norma de cunho indiscutivelmente emancipatório interpretação restritiva, a ponto de concluir que nela existe impeditivo à legitimação jurídica das uniões homoafetivas, lógica que há de estender ao art. 1.723 do Código Civil.

Algumas observações, ao final, são necessárias:

O reconhecimento, em cada caso concreto, de uma união estável homoafetiva jamais prescindirá da comprovação - pelos meios legal e moralmente admitidos - da existência de convivência contínua, duradoura e estabelecida com o propósito de constituição de entidade familiar. Evidentemente, o requisito da publicidade da relação também é relevante, mas merecerá algum temperamento, pois é compreensível que muitos relacionamentos tenham sido mantidos em segredo, com vistas à preservação dos envolvidos, com relação ao preconceito e a intolerância. ${ }^{251}$

A Ministra Cármen Lúcia, terceira a votar, observou que:

A conquista de direitos é tão difícil quanto curiosa. A luta pelos direitos é árdua para a geração que cuida de batalhar pela sua aquisição. E parece uma obviedade para as gerações que os vivem como realidades conquistadas e consolidadas.

Ressaltou, ainda, que:

Contra todas as formas de preconceito, contra quem quer que seja, há o direito constitucional. E este é um tribunal que tem a função precípua de defender e garantir os direitos constitucionais.

\section{Enfatizou que:}

O Direito existe para a vida e não a vida para o Direito.

No seu entender,

É exato que o $\S 3^{\circ}$ do art. 226 da Constituição é taxativo ao identificar que "Para efeito da proteção do Estado, é reconhecida a união estável entre o homem e a mulher como entidade familiar".

Tanto não pode significar, entretanto, que a união homoafetiva, a dizer, de pessoas do mesmo sexo, seja constitucionalmente intolerável e intolerada, dando azo a que seja, socialmente, alvo de intolerância, abrigada pelo Estado Democrática de Direito. Esse se concebe sob o

251 Voto Ministro Luiz Fux. Disponível

http://www.stf.jus.br/arquivo/cms/noticiaNoticiaStf/anexo/ADI4277LF.pdf. Acesso em 19 abr. 2015. 
pálio da Constituição que firma os seus pilares normativos no princípio da dignidade da pessoa humana, que impõe a tolerância e a convivência harmônica de todos, com integral respeito às livres escolhas das pessoas.

Para ser digno há que ser livre. E a liberdade perpassa a vida de uma pessoa em todos os seus aspectos, aí incluído o da liberdade de escolha sexual, sentimental e de convivência com outrem.

O que é indigno leva ao sofrimento socialmente imposto. E sofrimento que o Estado abriga é antidemocrático. E a nossa é uma Constituição democrática.

Não seria pensável que se assegurasse constitucionalmente a liberdade e, por regra contraditória, no mesmo texto se tolhesse essa mesma liberdade, impedindo-se o exercício da livre escolha do modo de viver, pondo-se aquele que decidisse exercer o seu direito a escolhas pessoais livres como alvo de preconceitos sociais e de discriminações, à sombra do direito.

Aqueles que fazem opção pela união homoafetiva não podem ser desigualados em sua cidadania. Ninguém pode ser tido como cidadão de segunda classe porque, como ser humano, não aquiesceu em adotar modelo de vida não coerente com o que a maioria tenha como certo ou válido ou legítimo.

\section{Citando o Professor José Afonso da Silva:}

"O intérprete da constituição tem que partir da ideia de que ela é um texto que tem algo a dizer-nos que ainda ignoramos. É função da interpretação desvendar o sentido do texto constitucional; a interpretação é, assim, uma maneira pela qual o significado mais profundo do texto é revelado, para além mesmo do seu conteúdo material".

Daí porque, ao interpretar o art. 226 da Constituição, aquele autor assinala que "a entidade familiar fundada no casamento, portanto, não é mais a única consagrada pelo direito constitucional e, por consequência, pela ordem jurídica em geral; porque é da Constituição que irradiam os valores normativos que imantam todo o ordenamento jurídico. Ex facto oritur jus - diz o velho brocardo latino. A realidade é a causadora de representações jurídicas que, até um certo momento, permanecem à margem do ordenamento jurídico formal; mas a pressão dos fatos acaba por gerar certo reconhecimento da sociedade, que vai aceitando situações antes repudiadas, até o momento em que o legislador as disciplina, exatamente para contê-las no campo do controle social. Quantos sofrimentos passaram mães solteiras que, com seus filhos, eram marginalizadas pela sociedade e desprezadas pelo Estado, porque essa comunidade não era concebida como entidade familiar, porque o sistema constitucional só reconhecia a família biparental?"

E conclui:

Daí a escolha da vida em comum de duas pessoas do mesmo sexo não poder ser tolhida, por força de interpretação atribuída a uma norma legal, porque tanto contrariaria os princípios constitucionais que fundamentam o pluralismo político e social. 
E finalizou:

$\mathrm{Na}$ esteira, assim, da assentada jurisprudência dos tribunais brasileiros, que já reconhecem para fins previdenciários, fiscais, de alguns direitos sociais a união homoafetiva, tenho como procedentes as ações, nos termos dos pedidos formulados, para reconhecer admissível como entidade familiar a união de pessoas do mesmo sexo e os mesmos direitos e deveres dos companheiros nas uniões estáveis serem reconhecidos àqueles que optam pela relação homoafetiva. ${ }^{252}$

O quarto voto foi o do Ministro Ricardo Lewandowski, que manifestou seu pensamento mostrando que:

Assim, segundo penso, não há como enquadrar a união entre pessoas do mesmo sexo em nenhuma dessas espécies de família, quer naquela constituída pelo casamento, quer na união estável, estabelecida a partir da relação entre um homem e uma mulher, quer, ainda, na monoparental.

E, no caso sob exame, tenho que a norma constitucional, que resultou dos debates da Assembleia Constituinte, é clara ao expressar, com todas as letras, que a união estável só pode ocorrer entre o homem e a mulher, tendo em conta, ainda, a sua possível convolação em casamento.

Como, então, enquadrar-se, juridicamente, o convívio duradouro e ostensivo entre pessoas do mesmo sexo fundado em laços afetivos?

Ora, embora essa relação não se caracterize como uma união estável, penso que se está diante de outra forma de entidade familiar, um quarto gênero, não previsto no rol encartado no art. 226 da Carta Magna, a qual pode ser deduzida a partir de uma leitura sistemática do texto constitucional e, sobretudo, diante da necessidade de se dar concreção aos princípios da dignidade da pessoa humana, da igualdade, da liberdade, da preservação da intimidade e da não-discriminação por orientação sexual aplicáveis às situações sob análise.

Entendo que as uniões de pessoas do mesmo sexo que se projetam no tempo e ostentam a marca da publicidade, na medida em que constituem um dado da realidade fenomênica e, de resto, não são proibidas pelo ordenamento jurídico, devem ser reconhecidas pelo Direito, pois, como já diziam os jurisconsultos romanos, ex facto oritur jus.

A diferença, embora sutil, reside no fato de que, apesar de semelhante em muitos aspectos à união estável entre pessoas de sexo distinto, especialmente no que tange ao vínculo afetivo, à publicidade e à duração no tempo, a união homossexual não se confunde com aquela, eis que, por definição legal, abarca, exclusivamente, casais de gênero diverso.

252 ADI $\quad N^{\mathbf{2}} 4277$, voto Ministra Cármen Lúcia. Disponível em: http://www.stf.jus.br/arquivo/cms/noticiaNoticiastf/anexo/adi4277clpdf. Acesso em 20 mai. 2015. 
Como conceituar juridicamente a união homossexual, já que não há previsão normativa expressa a ampará-la seja na Constituição, seja na legislação ordinária?

Cumpre lançar mão da integração analógica. Como se sabe, ante a ausência de regramento legal específico, pode o intérprete empregar a técnica da integração, mediante o emprego da analogia, com o fim de colmatar as lacunas porventura existentes no ordenamento legal, aplicando, no que couber, a disciplina normativa mais próxima à espécie que lhe cabe examinar, mesmo porque o Direito, como é curial, não convive com a anomia.

Resta, então, estabelecer se o rol de entidades familiares, definido no art. 226 da Constituição, é taxativo ou meramente exemplificativo.

Valho-me de um trecho de instigante artigo da lavra de Suzana Borges Viegas de Lima:

"Para demonstrar que as relações homoafetivas constituem verdadeiras entidades familiares, temos como ponto de partida o rol descrito no artigo 226 da Constituição Federal, que, em nossa opinião, não é numerus clausus, e sim um rol exemplificativo, dada a natureza aberta das normas constitucionais. Para tanto, é essencial que se considere a evolução da família a partir de seus aspectos civis e constitucionais, buscando nos fenômenos da publicização e constitucionalização do Direito de Família, e, também, na repersonalização das relações familiares, os elementos para a afirmação das relações homoafetivas. A partir disso, encontramos um vasto campo para uma análise mais aprofundada da proteção legal das relações homoafetivas, assim como dos direitos que delas emanam, segundo o ordenamento jurídico vigente".

Tal é, também, o abalizado entendimento de Paulo Luiz Netto Lobo, para quem:

“A regra do $\S 4^{\circ}$ do art. 226 integra-se à cláusula geral de inclusão, sendo esse o sentido do termo "também" nela contido. "Também" tem o significado de igualmente, da mesma forma, outrossim de inclusão de fato sem exclusão de outros. Se dois forem os sentidos possíveis (inclusão ou exclusão), deve ser prestigiado o que melhor responda à realização da dignidade da pessoa humana, sem desconsideração das entidades familiares reais não explicitadas no texto. Os tipos de entidades familiares explicitados nos parágrafos do art. 226 da Constituição são meramente exemplificativos, sem embargo de serem os mais comuns, por isso mesmo merecendo referência expressa. As demais entidades familiares são tipos implícitos incluídos no âmbito de abrangência do conceito amplo e indeterminado de família indicado no caput. Como todo conceito indeterminado, depende de concretização dos tipos, na experiência da vida, conduzindo à tipicidade aberta, dotada de ductibilidade e adaptabilidade."

Nesse sentido, aliás, observa o Professor Álvaro Villaça Azevedo que:

“(...) a Constituição de 1988, mencionando em seu caput que a família é a "base da sociedade", tendo "especial proteção do Estado", nada mais necessitava 0 art. 226 de dizer no tocante à formação familiar, podendo o 
legislador constituinte ter deixado de discriminar as formas de constituição da família. Sim porque ao legislador, ainda que constituinte, não cabe dizer ao povo como deve ele constituir sua família. $O$ importante é proteger todas as formas de constituição família, sem dizer o que é melhor.

E arremata:

Não há, ademais, penso eu, como escapar da evidência de que a união homossexual, em nossos dias, é uma realidade de elementar constatação empírica, a qual está a exigir o devido enquadramento jurídico, visto que dela resultam direitos e obrigações que não podem colocar-se à margem da proteção do Estado, ainda que não haja norma específica a assegurálos.

Assim, muito embora o texto constitucional tenha sido taxativo ao dispor que a união estável é aquela formada por pessoas de sexos diversos, tal ressalva não significa que a união homoafetiva pública, continuada e duradoura não possa ser identificada como entidade familiar, apta a merecer a proteção estatal, diante do rol meramente exemplificativo do art. 226, quando mais não seja em homenagem aos valores e princípios basilares do texto constitucional.

O que se pretende ao empregar-se o instrumento metodológico da integração?

$\mathrm{O}$ que se pretende, ao empregar-se o instrumento metodológico da integração, não é, à evidência, substituir a vontade do constituinte por outra arbitrariamente escolhida, mas apenas, tendo em conta a existência de um vácuo normativo, procurar reger uma realidade social superveniente a essa vontade, ainda que de forma provisória, ou seja, até que o Parlamento lhe dê o adequado tratamento legislativo.

Cuida-se, em outras palavras, de retirar tais relações, que ocorrem no plano fático, da clandestinidade jurídica em que se encontram, reconhecendo-lhes a existência no plano legal, mediante seu enquadramento no conceito abrangente de entidade familiar.

O proceder metodológico encontra apoio no abalizado entendimento de Konrad Hesse, segundo o qual:

“o que não aparece de forma clara como conteúdo da Constituição é o que deve ser determinado mediante a incorporação da "realidade" de cuja ordenação se trata". Dito de outro modo, não é dado ao intérprete constitucional, a pretexto de ausência de previsão normativa, deixar de dar solução aos problemas que emergem da realidade fenomênica, sob pena, inclusive, em nosso caso, de negar vigência ao disposto no art. $5^{\circ}$, XXXV, da Lei Maior.

Finalmente deixa claro que:

Não se está aqui a reconhecer uma "união estável homoafetiva", por interpretação extensiva do $\S 3^{\circ}$ do art. 226 , mas uma "união homoafetiva estável", mediante um processo de integração analógica. Quer dizer, 
desvela-se, por esse método, outra espécie de entidade familiar, que se coloca ao lado daquelas formadas pelo casamento, pela união estável entre um homem e uma mulher e por qualquer dos pais e seus descendentes, explicitadas no texto constitucional.

Cuida-se, enfim, a meu juízo, de uma entidade familiar que, embora não esteja expressamente prevista no art. 226, precisa ter a sua existência reconhecida pelo Direito, tendo em conta a existência de uma lacuna legal que impede que o Estado, exercendo o indeclinável papel de protetor dos grupos minoritários, coloque sob seu amparo as relações afetivas públicas e duradouras que se formam entre pessoas do mesmo sexo.

Finaliza seu voto assegurando que:

Em suma, reconhecida a união homoafetiva como entidade familiar, aplicam-se a ela as regras do instituto que lhe é mais próximo, qual seja, a união estável heterossexual, mas apenas nos aspectos em que são assemelhados, descartando-se aqueles que são próprios da relação entre pessoas de sexo distinto, segundo a vetusta máxima ubi eadem ratio ibi idem jus, que fundamenta o emprego da analogia no âmbito jurídico ${ }^{253}$.

O quinto ministro a votar foi Joaquim Barbosa.

Inicialmente, gostaria de ressaltar que estamos diante de uma situação que demonstra claramente o descompasso entre o mundo dos fatos e o universo do Direito.

Quanto ao papel das Cortes Supremas e Constitucionais:

As Cortes Supremas e Constitucionais devem fazer a ponte entre o mundo do Direito e a Sociedade.

Com relação às relações afetivas entre pessoas do mesmo sexo:

Relações estas que em nada diferem das relações afetivas heterossexuais, a não ser pelo fato de serem compostas por pessoas do mesmo sexo. Essa realidade social é incontestável. Essas uniões sempre existiram e existirão. $\mathrm{O}$ que varia e tem variado é o olhar que cada sociedade lança sobre elas em cada momento da evolução civilizatória e em cada parte do mundo.

Vejamos o que diz o ordenamento jurídico-constitucional brasileiro sobre essa questão:

Quanto à Constituição Federal, muitos poderão argumentar que ela é silente sobre a matéria. Porém, cumpre indagar o seguinte: o silêncio da Constituição deve ser interpretado como indiferença, desprezo ou hostilidade?

253 Voto Ministro Ricardo Lewandowski na ADPF 132 e ADI 4.277. Disponível em: http://www.stf.jus.br/arquivo/cms/noticiaNoticiastf/anexo/ADI4277RL.pdf. Acesso em 03 fev. 2014. 
Creio que não. Cumpre a esta Corte verificar se o desprezo jurídico que se pretende dar a essas relações é compatível com a Constituição. Aí, sim, estará esta Corte a desempenhar uma das suas mais nobres missões: a de impedir o sufocamento, o desprezo, a discriminação pura e dura de um grupo minoritário pelas maiorias estabelecidas.

Nessa linha de pensamento, é imperioso notar, de início, que não há, no texto constitucional, qualquer alusão ou mesmo proibição ao reconhecimento jurídico das uniões homoafetivas.

O reconhecimento dos direitos das pessoas que mantêm relações homoafetivas decorre, a meu sentir, do acolhimento no nosso sistema jurídico do postulado ou da ideia de reconhecimento, uma emanação do princípio da dignidade humana.

Entendo, pois, que o reconhecimento dos direitos oriundos de uniões homoafetivas encontra fundamento em todos os dispositivos constitucionais que estabelecem a proteção dos direitos fundamentais, no princípio da dignidade da pessoa humana, no princípio da igualdade e da não-discriminação. ${ }^{254}$

O Ministro Gilmar Mendes foi o sexto a votar:

A questão do reconhecimento da união entre pessoas do mesmo sexo:

Parece-me que a questão central a ser considerada neste julgamento refere-se à legitimidade constitucional de reconhecimento jurídico da união entre pessoas do mesmo sexo. Indaga-se, ainda, sobre a possibilidade de aplicação analógica do regime da união estável entre homem e mulher, diante da ausência de um modelo institucional mínimo de proteção da união homoafetiva.

Primeiramente, constata-se a ausência de regulamentação normativa específica acerca da união entre pessoas do mesmo sexo e a falta de um modelo institucional mínimo no Brasil, a trazer insegurança jurídica e prejuízos ao reconhecimento de direitos na esfera estatal e no âmbito das relações públicas e privadas.

Esses impasses, por vezes, têm sido levados à apreciação do Poder Judiciário e os tribunais brasileiros vêm adotando posicionamentos distintos, conforme demonstram os documentos juntados aos autos. Há decisões judiciais em que se nega validade jurídica à união homoafetiva (por impossibilidade jurídica do pedido). Em outras situações, reconhecese a relação como sociedade de fato, no âmbito dos direitos das obrigações. Em outros casos, avança-se para afirmar a união homoafetiva como entidade familiar, equiparada à união estável no que couber. A depender do entendimento adotado, poderão ser declaradas competentes a vara cível ou a vara de família.

A controvérsia política e a ausência de uma deliberação consensual do Congresso:

254 Voto do Ministro Joaquim Barbosa na ADI 4.277/DF. Disponível em: http://redir.stf.jus.br/paginadorpub/paginador.jsp?docTP=AC\&dicID=628635. Acesso em 05 jul. 2015. 
Além das proposições legislativas mencionadas, há ainda outras no plano legislativo federal que versaram ou ainda versam sobre temas conexos e até mesmo sobre os mesmos assuntos.

Como antes ressaltado, esse levantamento é ilustrativo e não tem a intenção de analisar exaustivamente as proposições sobre a matéria da união homoafetiva. No entanto, por meio desse exame, colhem-se indícios de que, apesar de o Poder Legislativo debruçar-se sobre o tema há mais de 15 anos, até hoje, não conseguiu chegar a consenso básico para aprovação de qualquer regulamentação.

O Poder Legislativo, em regra, não entra em consenso, mas continua a enfrentar o tema. Todavia, a demora em aprovar legislação gera nos interessados angústia natural e um sentimento de desproteção, para a qual buscam solução no Judiciário.

Além disso, das proposições legislativas e dos debates travados no Parlamento, pode-se notar que parece haver maior consenso relativamente a alguns temas, tais como os efeitos previdenciários da união homoafetiva, ao passo que outros assuntos são bastante controvertidos (como é o caso da adoção de crianças por casais homoafetivos).

O reconhecimento da união homoafetiva como afirmação de direitos de minorias:

É evidente também que aqui nós não estamos a falar apenas da falta de uma disciplina legislativa que permita o desenvolvimento de uma dada política pública. Nós estamos a falar, realmente, do reconhecimento do direito de minorias, de direitos fundamentais básicos. $E$, nesse ponto, não se trata de ativismo judicial, mas de cumprimento da própria essência da jurisdição constitucional.

Não há dúvida de que se impõe tal proteção, sobretudo em razão do que dispõe o art. $5^{\circ}$, inciso XLI da Constituição, ao determinar que "a lei punirá qualquer discriminação atentatória dos direitos e liberdades fundamentais".

O problema das lacunas valorativas ou axiológicas e a ideia da aplicação do pensamento possível:

Preocupa-me, contudo, que esta Corte desde logo conceda ampla extensão aos efeitos jurídicos do reconhecimento da união homoafetiva sem uma maior reflexão, inclusive da própria sociedade e do Congresso Nacional, em razão da infinidade de implicações práticas e jurídicas, previsíveis e imprevisíveis, que isso pode acarretar.

É que se nós reconhecermos que há esse direito ou que há direitos a uma proteção, em seguida deve-se indagar sobre o seu correspondente dever de proteção. $E$ a essa lacuna ou a essa não disciplina normativa do dever de proteção, impõe-se também algum tipo de solução. E, aí, certamente nós podemos, então, ter diversas divergências apenas de como fazê-lo.

Conclusão do voto: 
Por isso, neste momento, limito-me a reconhecer a existência da união entre pessoas do mesmo sexo, por fundamentos jurídicos próprios e distintos daqueles explicitados pelo Ministro Ayres Britto e, com suporte na teoria do pensamento do possível, determinar a aplicação de um modelo de proteção semelhante - no caso, o que trata da união estável -, naquilo que for cabível, nos termos da fundamentação aqui apresentada, sem me pronunciar sobre outros desdobramentos.

Destaco que a decisão do Supremo não significa óbice à atuação do Poder Legislativo. Pelo contrário, a nossa decisão deve ser entendida como um imperativo de regulação da união homoafetiva, como decorrência da necessidade de concretização de um dever de proteção de direitos fundamentais relacionados a essa relação jurídica. Trata-se de um estímulo institucional para que, de fato, as mais diversas situações jurídicas que envolvem a união entre pessoas do mesmo sexo venham a ser disciplinadas. ${ }^{255}$

O sétimo voto foi o da Ministra Ellen Grace, que também votou pela procedência da ação. Iniciou seu voto fazendo referência ao conceito de família e a proteção que esta recebe no direito brasileiro.

A ministra finalizou seu voto dizendo que o Supremo: "restitui aos homossexuais o respeito que merecem, reconhece seus direitos, restaura a sua dignidade, afirma a sua identidade e restaura a sua liberdade."256

O oitavo voto foi o do Ministro Marco Aurélio. Iniciou seu voto com as seguintes considerações:

O cerne da questão em debate: saber se a convivência pública, duradoura e com ânimo de formar família, por pessoas de sexo igual deve ser admitida como entidade familiar à luz da Lei Maior, considerada a omissão legislativa. Em caso positivo, cabe a aplicação do regime previsto no artigo 1.723 do Código Civil de 2002?

A corrente contrária a tal reconhecimento argumenta que o $\S 3^{\circ}$ do artigo 226 da Carta da República remete tão-somente à união estável entre homem e mulher, o que se poderia entender como silêncio eloquente do constituinte no tocante à união entre pessoas de mesmo sexo. Além disso, o artigo 1.723 do Código Civil de 2002 apenas repetiria a redação do texto constitucional, sem fazer referência à união homoafetiva, a revelar a dupla omissão, o que afastaria do âmbito de incidência da norma a união de pessoas de sexo igual.

255 Voto do Ministro Gilmar Mendes na ADI 4.277/DF. Disponível em: http://redir.stf.jus.br/paginarpub/paginador.jsp2docTP=AC\&doc=ID=628635. Acesso em 07 jul. 2015.

${ }^{256}$ Ministra Ellen Grace acompanha voto do relator reconhecendo a união homoafetiva. Disponível em http://www.stf.jus.br/portal/cms/verNoticiaDetalhe.asp?idConteudo=178937. Acesso em 07 jul. 2015. 
Esta é a opinião que pode ser pinçada das decisões judiciais anexadas ao processo, compartilhada por Álvaro Villaça Azevedo ("União entre pessoas do mesmo sexo", Direito de família e sucessões, 2008, p. 17).

Daí a dificuldade hermenêutica: seria possível incluir nesse regime uma situação que não foi originalmente prevista pelo legislador ao estabelecer a premissa para a consequência jurídica? Não haveria transbordamento dos limites da atividade jurisdicional? A resposta à ultima questão, adianto, é desenganadamente negativa.

Afirmou ser incorreta a prevalência, em todas as esferas, de razões morais ou religiosas.

Especificamente quanto à religião, não podem a fé e as orientações morais dela decorrentes ser impostas a quem quer que seja e por quem quer que seja. As garantias de liberdade religiosa e do Estado Laico impedem que concepções morais religiosas guiem o tratamento estatal dispensado a direitos fundamentais, tais como o direito à dignidade da pessoa humana, o direito à autodeterminação, o direito à privacidade e $\mathrm{o}$ direito à liberdade de orientação sexual.

A ausência de aprovação dos diversos projetos de lei que encampam a tese sustentada pelo requerente, descontada a morosidade na tramitação, indica a falta de vontade coletiva quanto à tutela jurídica das uniões homoafetivas.

Quanto ao reconhecimento da entidade familiar:

Se o reconhecimento da entidade familiar depende apenas da opção livre e responsável de constituição de vida comum para promover a dignidade dos partícipes, regida pelo afeto existente entre eles, então não parece haver dúvida de que a Constituição Federal de 1988 permite seja a união homoafetiva admitida como tal. Esta é a leitura normativa que faço da carta e dos valores por ela consagrados, em especial das cláusulas contidas nos artigo $1^{\circ}$, inciso III, $3^{\circ}$, incisos II e IV e $5^{\circ}$, cabeça e inciso I.

\section{A transformação operada pela atual Constituição:}

Percebam que a transformação operada pela atual Constituição não se resumiu ao direito de família. A partir de 1988, ocorreu a ressignificação do ordenamento jurídico. Como é cediço, compete aos intérpretes efetuar a filtragem constitucional dos institutos previstos na legislação infraconstitucional. Esse fenômeno denominado "constitucionalização do Direito", na expressão de uso mais corriqueiro, revela que não podemos nos ater ao dogmatismo ultrapassado, que então prevalecia no Direito Civil.

Esse ramo do Direito voltou-se à tutela das situações jurídico-existenciais e, apenas em caráter secundário, às situações jurídico-patrimoniais.

Relegar as uniões homoafetivas à disciplina da sociedade de fato é não reconhecer essa modificação paradigmática no Direito Civil levada a cabo pela Constituição da República. 
De nada adiantaria a positivação de direitos na Constituição, se eles fossem lidos em conformidade com a opinião pública dominante.

Com base nesses fundamentos, concluo que é obrigação constitucional do Estado reconhecer a condição familiar e atribuir efeitos jurídicos às uniões homoafetivas. Entendimento contrário discrepa, a mais não poder, das garantias e direitos fundamentais, dá eco a preconceitos ancestrais, amesquinha a personalidade do ser humano e, por fim, desdenha o fenômeno social, como se a vida comum com intenção de formar família entre pessoas de sexo igual não existisse ou fosse irrelevante para a sociedade.

Quanto à equiparação das uniões homoafetivas ao regime das uniões estáveis, previsto no artigo 1.723 do Código Civil de 2002:

O óbice gramatical pode ser contornado com o recurso a instrumento presente nas ferramentas tradicionais de hermenêutica. Não é recente a evolução doutrinária relativa à teoria das normas jurídicas, nas quais se ampliou a compreensão da função e do papel dos princípios no ordenamento jurídico.

Extraio do núcleo do princípio da dignidade da pessoa humana a obrigação de reconhecimento das uniões homoafetivas. Inexiste vedação constitucional à aplicação do regime da união estável a essas uniões, não se podendo vislumbrar silêncio eloquente em virtude da redação do $\S 3^{\circ}$ do artigo 226. Há, isso sim, a obrigação constitucional de não discriminação e de respeito à dignidade humana, às diferenças, à liberdade de orientação sexual, o que impõe o tratamento equânime entre homossexuais e heterossexuais. Nesse contexto, a literalidade do artigo 1.723 do Código Civil está muito aquém do que consagrado pela Carta de 1988. Não retrata fielmente o propósito de reconhecer direitos a grupos minoritários.

Por isso, Senhor Presidente, julgo procedente o pedido formulado para conferir interpretação conforme a Constituição ao artigo 1.723 do Código Civil, veiculado pela Lei $\mathrm{n}^{\circ} 10.406 / 2002$, a fim de declarar a aplicabilidade do regime da união estável às uniões entre pessoas de sexo igual. $^{257}$

O nono voto foi proferido pelo Ministro Celso de Melo. O reconhecimento, por imperativo constitucional, da união estável homoafetiva como legítima entidade familiar:

$\mathrm{Na}$ realidade, Senhor Presidente, o julgamento que hoje se realiza certamente marcará a vida deste País e imprimirá novos rumos à causa da comunidade homossexual.

Citando Daniel Sarmento (Casamento e União Estável entre pessoas do mesmo Sexo) sobre o exato sentido da norma constitucional do art. $226, \S$ $3^{\circ}$ :

257 Voto do Ministro Marco Aurélio na ADI 4.277/DF. Disponível em: http://www.stf.jus.br/arquivo/cms/noticiaNoticiaStf/anexo/ADI4277/MA.pdf. Acesso em 28 jun. 2015. 
Um obstáculo bastante invocado contra a possibilidade de reconhecimento da união estável entre pessoas do mesmo sexo é a redação do art. 226, § $3^{\circ}$, da Constituição, segundo o qual "para o efeito de proteção do Estado, é reconhecida a união estável entre o homem e a mulher como entidade familiar, devendo a lei facilitar a sua conversão em casamento".

Os adversários da medida alegam que o preceito em questão teria barrado a possibilidade do reconhecimento da união homoafetiva no Brasil, pelo menos enquanto não fosse aprovada emenda alterando o texto constitucional. Contudo, o argumento, que se apega exclusivamente na literalidade do texto, não procede.

Com efeito, sabe-se que a Constituição, em que pese o seu caráter compromissório, não é apenas um amontoado de normas isoladas. Pelo contrário, trata-se de um sistema aberto de princípios e regras, em que cada um dos elementos dever ser compreendido à luz dos demais. A noção de sistema traduz-se num importantíssimo princípio de hermenêutica constitucional, que é o da unidade da Constituição.

No sistema constitucional, existem princípios fundamentais que desempenham um valor mais destacado no sistema, compondo a sua estrutura básica.

No caso brasileiro, nem é preciso muito esforço exegético para indentifica-los. O constituinte já tratou de fazê-lo no Título I da Carta, que se intitula exatamente "Dos Princípios Fundamentais". E é lá que vão ser recolhidas as cláusulas essenciais para a nossa empreitada hermenêutica: princípios da dignidade da pessoa humana, do Estado Democrático de Direito, da construção de uma sociedade livre, justa e solidária, livre de preconceitos e discriminações, dentre outros.

Estes vetores apontam firmemente no sentido de que a exegese das normas setoriais da Constituição - como o nosso $\S 3^{\circ}$ do art. 226 -, deve buscar a inclusão e não a exclusão dos estigmatizados; a emancipação dos grupos vulneráveis e não a perenização do preconceito e da desigualdade.

\section{(...)}

Da leitura do enunciado normativo reproduzido, verifica-se que ele assegurou expressamente o reconhecimento da união estável entre homem e mulher, mas nada disse sobre a união civil dos homossexuais.

Esta ausência de referência não significa, porém, silêncio eloquente da Constituição. $\mathrm{O}$ fato de que o texto omitiu qualquer alusão à união entre pessoas do mesmo sexo não implica, necessariamente, que a Constituição não assegure o seu reconhecimento.

Não bastasse o elemento teleológico da interpretação constitucional também não é compatível com a leitura do art. $226, \S 3^{\circ}$, da Constituição, segundo a qual do referido preceito decorreria, "a contrario sensu", o banimento constitucional da união entre pessoas do mesmo sexo. 
Com efeito, o referido preceito foi inserido no texto constitucional no afã de proteger os companheiros das uniões não matrimonializadas, coroando um processo histórico que teve início na jurisprudência cível, e que se voltava à inclusão social e à superação do preconceito. Por isso, é um contra-senso interpretar este dispositivo constitucional, que se destina a "inclusão", como uma cláusula de exclusão social, que tenha como efeito discriminar os homossexuais".

Ativismo judicial?

Na realidade, o Supremo Tribunal Federal, ao suprir as omissões inconstitucionais dos órgãos estatais e ao adotar medidas que objetivem restaurar a Constituição violada pela inércia dos poderes do Estado, nada mais faz senão cumprir a sua missão constitucional e demonstrar, com esse gesto, o respeito incondicional que tem pela autoridade da Lei Fundamental da República.

Concluindo seu voto:

Concluo o meu voto, senhor Presidente. E ao fazê-lo, julgo procedente a presente ação constitucional, para com efeito vinculante, declarar a obrigatoriedade do reconhecimento, como entidade familiar, a união entre pessoas do mesmo sexo, desde que atendidos os mesmo requisitos exigidos para a constituição da união estável entre homem e mulher, além de também reconhecer, com idêntica eficácia vinculante, que os mesmos direitos e deveres dos companheiros nas uniões estáveis estendem-se aos companheiros na união entre pessoas do mesmo sexo. ${ }^{258}$

O último voto foi o do Ministro Cezar Peluso.

Começo por dizer que teria alguma dificuldade de ordem teórica para conhecer das demandas como ações diretas de inconstitucionalidade, não fosse o fato de que o disposto no artigo 1.723 do Código Civil não é reprodução estrita do artigo $226, \S 3^{\circ}$, da Constituição Federal. Porque, se o fosse, obstáculo teórico e, a meu ver, constitucional, estaria em que não seria possível cogitar-se de interpretação conforme à Constituição de norma infraconstitucional que se limitaria, nessa hipótese, a reproduzir texto constitucional. Estaríamos, sim, diante de um caso de pura interpretação constitucional, que não poderia ser objeto de ação de inconstitucionalidade sob pretexto de que teríamos que interpretar a própria Constituição de acordo com a Constituição.

Mas a diversidade de redação das normas permite, e acho que isto é, de modo consistente, a sua racionalidade, a decisão da Corte de conhecer das demandas, exatamente com base na não coincidência semântica entre as duas normas, de tal modo que é possível enxergar o disposto no artigo 1.723 como preceito susceptível de revisão à luz do artigo $226, \S 3^{\circ}$, e de outras normas constitucionais, que constam, aliás, como causa de pedir de ambas as demandas.

A norma do artigo 226, $\S 3^{\circ}$ da Constituição da República não exclui outras modalidades de entidade familiar.

258 Voto do Ministro Celso de Mello. Disponível em:


Não se trata de numerus clausus. De modo que permite dizer que, tomando em consideração outros princípios da Constituição, como o princípio da dignidade, o princípio da igualdade, o princípio específico da não discriminação e outros, é lícito conceber, na interpretação de todas essas normas constitucionais, que, além daquelas explicitamente catalogadas na Constituição, haja outras entidades que podem ser tidas normativamente como familiares, tal como se dá no caso.

E a segunda consequência é que, na disciplina dessa entidade familiar recognocível à vista de uma interpretação sistemática das normas constitucionais, não se pode deixar de reconhecer - e este é o meu fundamento, a cujo respeito eu peço vênia para divergir da posição do ilustre Relator e de outros que o acompanharam nesse passo - que há uma lacuna normativa, a qual precisa de ser preenchida. E se deve preenchêla, segundo as regras tradicionais, pela aplicação da analogia, diante, basicamente, da similitude - não da igualdade - da similitude factual entre ambas as entidade de que cogitamos: a união estável entre o homem e a mulher e a união entre pessoas do mesmo sexo. E essa similitude entre ambas situações é que me autoriza dizer que a lacuna consequente tem que ser preenchida por algumas normas. E a pergunta é: por que classe de normas?

Que classe de normas?

De modo que, na solução da questão posta, a meu ver e de todos os Ministros da Corte, só podem ser aplicadas as normas correspondentes àquelas que, no Direito de Família, se aplicam à união estável entre o homem e a mulher. Mas nem todas, porque não se trata de situações absolutamente idênticas, senão, como todos tratamos, de equiparação, e de equiparação porque não há, na verdade, igualdade. E, portanto, é preciso respeitar aquilo que cada instituição, em si, tem de particular, não apenas por sua natureza extrajurídica, mas também pela própria natureza normativa de cada qual.

Tem que intervir o Poder Legislativo:

O Poder Legislativo, a partir de hoje, deste julgamento, precisa expor-se e regulamentar as situações em que a aplicação da decisão da Corte será justificada também do ponto de vista constitucional. Há, portanto, uma como convocação que a decisão da Corte implica em relação ao Poder Legislativo, para que assuma essa tarefa, a qual parece que até agora não se sentiu ainda propenso a exercer, de regulamentar esta equiparação. ${ }^{259}$

Com relação à Ementa do acórdão da ADI 4.277/DF, 05/05/2011 260:

Ementa: 1. ARGUIÇÃO DE DESCUMPRIMENTO DE PRECEITO FUNDAMENTAL (ADPF). PERDA PARCIAL DE OBJETO. RECEBIMENTO, NA PARTE REMANESCENTE, COMO AÇÃO

259 Voto do ministro Cezar Peluso (Presidente) na ADI 4.277/DF. Disponível em: http://redir.stf.jus.br/paginadorpub/paginador.jsp2docTP=AC\&docID=628635. Acesso em 05 jul. 2015.

260 Ementa e Acórdão da ADI 4.277/DF. Disponível em: http://redir.stf.jus.br/paginadorpub/paginador.jsp?docTP=AC\&docID=628635 p. 611-615. Acesso em 05 jul. 2015. 
DIRETA DE INCONSTITUCIONALIDADE. UNIÃO HOMOAFETIVA E SEU RECONHECIMENTO COMO INSTITUTO JURÍDICO. CONVERGÊNCIA DE OBJETOS ENTRE AÇÕES DE NATUREZA ABSTRATA. JULGAMENTO CONJUNTO. Encampação dos fundamentos da ADPF $n^{\circ} 132-R J$ pela ADI $n^{\circ}$ 4.277-DF, com a finalidade de conferir "interpretação conforme à Constituição" ao art. 1.723 do Código Civil. Atendimento das condições da ação.

2. PROIBIÇÃO DE DISCRIMINAÇÃO DAS PESSOAS EM RAZÃO DO SEXO, SEJA NO PLANO DA DICOTOMIA HOMEM/MULHER (GÊNERO) SEJA NO PLANO DA ORIENTAÇÃO SEXUAL DE CADA QUAL DELES. A PROIBIÇÃO DO PRECONCEITO COMO CAPÍTULO DO CONSTITUCIONALISMO FRATERNAL. HOMENAGEM AO PLURALISMO COMO VALOR SÓCIOPOLÍTICO-CULTURAL. LIBERDADE PARA DISPOR DA PRÓPRIA SEXUALIDADE, INSERIDA NA CATEGORIA DOS DIREITOS FUNDAMENTAIS DO INDIVÍDUO, EXPRESSÃO QUE É DA AUTONOMIA DE VONTADE. DIREITO À INTIMIDADE E À VIDA PRIVADA. CLÁUSULA PÉTREA. O sexo das pessoas, salvo disposição constitucional expressa ou implícita em sentido contrário, não se presta como fator de desigualação jurídica. Proibição de preconceito, à luz do inciso IV do art. $3^{\circ}$ da Constituição Federal, por colidir frontalmente com o objetivo constitucional de "promover o bem de todos". Silêncio normativo da Carta Magna a respeito do concreto uso do sexo dos indivíduos como saque da kelsiniana "norma geral negativa", segundo a qual "o que não estiver juridicamente proibido, ou obrigado, está juridicamente permitido". Reconhecimento do direito à preferência sexual como direta emanação do princípio da "dignidade da pessoa humana": direito a auto-estima no mais elevado ponto da consciência do indivíduo. Direito à busca da felicidade. Salto normativo da proibição do preconceito para a proclamação do direito à liberdade sexual. O concreto uso da sexualidade faz parte da autonomia da vontade das pessoas naturais. Empírico uso da sexualidade nos planos da intimidade e da privacidade constitucionalmente tutelada. Autonomia da vontade. Cláusula pétrea.

3. TRATAMENTO CONSTITUCIONAL DA INSTITUIÇÃO DA FAMÍLIA. RECONHECIMENTO DE QUE A CONSTITUIÇÃO FEDERAL NÃO EMPRESTA AO SUBSTANTIVO "FAMÍLIA" NENHUM SIGNIFCADO ORTODOXO OU DA PRÓPRIA TÉCNICA JURÍDICA. A FAMÍLIA COMO CATEGORIA SÓCIO-CULTURAL E PRINCÍPIO ESPIRITUAL. DIREITO SUBJETIVO DE CONSTITUIR FAMÍLIA. INTERPRETAÇÃO NÃO-REDUCIONISTA. O caput do art. 226 confere à família, base da sociedade, especial proteção do Estado. Ênfase constitucional à instituição da família. Família em seu coloquial ou proverbial significado de núcleo doméstico, pouco importando se formal ou informalmente constituída, ou se integrada por casais heteroafetivos ou por pares homoafetivos. A Constituição de 1988, ao utilizar-se da expressão "família", não limita sua formação a casais heteroafetivos nem a formalidade cartorária, celebração civil ou liturgia religiosa. Família como instituição privada que, voluntariamente constituída entre pessoas adultas, mantém com o Estado e a sociedade civil uma necessária relação tricotômica. Núcleo familiar que é o principal lócus institucional de concreção dos direitos fundamentais que a própria Constituição designa por "intimidade e vida privada" (inciso X do 
art. $5^{\circ}$ ). Isonomia entre casais heteroafetivos e pares homoafetivos que somente ganha plenitude de sentido se desembocar no igual direito subjetivo à formação de uma autonomizada família. Família como figura central ou continente, de que tudo o mais é conteúdo. Imperiosidade da interpretação não-reducionista do conceito de família como instituição que também se forma por vias distintas do casamento civil. Avanço da Constituição Federal de 1988 no plano dos costumes. Caminhada na direção do pluralismo como categoria sócio-político-cultural. Competência do Supremo Tribunal Federal para manter, interpretativamente, o Texto Magno na posse do seu fundamental atributo da coerência, o que passa pela eliminação de preconceito quanto à orientação sexual das pessoas.

4. UNIÃO ESTÁVEL. NORMAÇÃO CONSTITUCIONAL REFERIDA A HOMEM E MULHER, MAS APENAS PARA ESPECIAL PROTEÇÃO DESTA ÚLTIMA. FOCADO PROPÓSITO CONSTITUCIONAL DE ESTABELECER RELAÇÕES JURÍDICAS HORIZONTAIS OU SEM HIERARQUIA ENTRE AS DUAS TIPOLOGIAS DO GÊNERO HUMANO. IDENTIDADE CONSTITUCIONAL DOS CONCEITOS DE "ENTIDADE FAMILIAR" E "FAMÍLIA". A referência constitucional à dualidade básica homem/mulher, no $\S 3^{\circ}$ do seu art. 226 , deve-se ao centrado intuito de não se perder a menor oportunidade para favorecer relações jurídicas horizontais ou sem hierarquia no âmbito das sociedades domésticas. Reforço normativo a um mais eficiente combate à renitência patriarcal dos costumes brasileiros. Impossibilidade de uso da letra da Constituição para ressuscitar o art. 175 da Carta de 1967/1969. Não há como fazer rolar a cabeça do art. 226 no patíbulo do seu parágrafo terceiro. Dispositivo que, ao utilizar da terminologia "entidade familiar", não pretendeu diferenciá-la da "família". Inexistência de hierarquia ou diferença de qualidade jurídica entre as duas formas de constituição de um novo e autonomizado núcleo doméstico. Emprego do fraseado "entidade familiar" como sinônimo perfeito de família. A Constituição não interdita a formação de família por pessoas do mesmo sexo. Consagração do juízo de que não se proíbe nada a ninguém senão em face de um direito ou de proteção de um legítimo interesse de outrem, ou de toda a sociedade, o que não se dá na hipótese sub judice. Inexistência do direito dos indivíduos heteroafetivos à sua não-equiparação jurídica com os indivíduos homoafetivos. Aplicabilidade do $\S 2^{\circ}$ do art. $5^{\circ}$ da Constituição Federal, a evidenciar que outros direitos e garantias, não expressamente listados na Constituição, emergem "do regime e dos principios por ela adotados", verbis: "Os direitos e garantias expressos nesta Constituição não excluem outros decorrentes do regime e dos princípios por ela adotados, ou dos tratados internacionais em que a República Federativa do Brasil seja parte".

5. DIVERGÊNCIAS LATERAIS QUANTO À FUNDAMENTÇÃO DO ACÓRDÃO. Anotação de que os Ministros Ricardo Lewandowski, Gilmar Mendes e Cezar Peluso convergiram no particular entendimento da impossibilidade de ortodoxo enquadramento da união homoafetiva nas espécies de família constitucionalmente estabelecidas. Sem embargo, reconheceram a união entre parceiros do mesmo sexo como uma nova forma de entidade familiar. Matéria aberta à conformação legislativa, sem prejuízo do reconhecimento da imediata auto-aplicabilidade da Constituição. 
6. INTERPRETAÇÃO DO ART. 1.723 DO CÓDIGO CIVIL EM CONFORMIDADE COM A CONSTITUIÇÃO FEDERAL (TÉCNICA DA “INTERPRETAÇÃO CONFORME"). RECONHECIMENTO DA UNIÃO HOMOAFETIVA COMO FAMÍLIA. PROCEDÊNCIA DAS AÇÕES. Ante a possibilidade de interpretação em sentido preconceituoso ou discriminatório do art. 1.723 do Código Civil, não resolúvel à luz dele próprio, faz-se necessária a utilização da técnica de "interpretação conforme à Constituição". Isso para excluir do dispositivo em causa qualquer significado que impeça o reconhecimento da união contínua, pública e duradoura entre pessoas do mesmo sexo como família. Reconhecimento que é de ser feito segundo as mesmas regras e com as mesmas consequências da união estável heteroafetiva.

\section{ACÓRDÃO}

Vistos, relatados e discutidos estes autos, acordam os Ministros do Supremo Tribunal Federal em conhecer da Arguição de Descumprimento de Preceito Fundamental 132 como ação direita de inconstitucionalidade, e julgá-la em conjunto com a ADI 4277, por votação unânime. Prejudicado o primeiro pedido originariamente formulado na ADPF, por votação unânime. Rejeitadas todas as preliminares, por votação unânime. Os ministros desta Casa de Justiça, ainda por votação unânime, acordam em julgar procedentes as ações, com eficácia erga omnes e efeito vinculante, com as mesmas regras e consequências da união estável heteroafetiva, autorizados os Ministros a decidirem monocraticamente sobre a mesma questão, independentemente da publicação do acórdão. Tudo em sessão presidida pelo Ministro Cezar Peluso, na conformidade da ata do julgamento e das notas taquigráficas. Votou o Presidente.

Brasília, 05 de maio de 2011.

\section{MINISTRO AYRES BRITTO - RELATOR}

Tendo em vista o comando do art. 102, § $2^{\circ}$ da Constituição Federal, a partir da decisão do Supremo Tribunal Federal, ninguém pode desobedecer o teor do julgamento proferido. Nem o Poder Judiciário e tampouco qualquer autoridade pública, de qualquer das instâncias do poder. Porque se tratou de julgamento de mérito proferido em Ação Direta de Inconstitucionalidade a decisão produz eficácia contra todos e efeito vinculante, com relação aos demais órgãos do Poder Judiciário e da Administração Pública direta e indireta, nas esferas federal, estadual e municipal. ${ }^{261}$

\footnotetext{
${ }^{261} \mathrm{CF}$, art. 102, $\S 2^{\circ}$ : As decisões definitivas de mérito, proferidas pelo Supremo Tribunal Federal, nas ações diretas de inconstitucionalidade e nas ações declaratórias de constitucionalidade produzirão eficácia contra todos e efeito vinculante, relativamente aos demais órgãos do Poder Judiciário e à administração pública direta e indireta, nas esferas federal, estadual e municipal.
} 


\subsection{As decisões judiciais após o julgamento pelo STF da ADI 4277/DF e ADPF 132/RJ}

Após o julgamento em 5 de maio de 2011, pelo Supremo Tribunal Federal das duas ações: Arguição de Descumprimento de Preceito Fundamental (ADPF 132/RJ) e Ação Direita de Inconstitucionalidade (ADI 4277/DF), ocorreram inúmeros pedidos de reconhecimento de uniões homoafetivas, conversão de união homoafetiva em casamento e habilitação direta para o casamento.

Em 27/06/2011 o juiz da $2^{\text {a }}$ Vara da Família e das Sucessões de Jacareí (SP), Fernando Henrique Pinto, homologou a conversão da união estável em casamento entre duas pessoas do mesmo sexo (ambos do sexo masculino), sendo a primeira vez que ocorreu um casamento homoafetivo no país. L.A.M e J.S.S., protocolaram a solicitação em que afirmam viver em união estável há oito anos. O Ministério Público deu parecer favorável ao pedido. O pedido foi instruído com declaração de duas testemunhas, que confirmaram que os dois "mantém convivência pública, contínua e duradoura e estabelecida com o objetivo de constituir família”. Foram realizados os proclamas e não houve impugnações. O principal fundamento da decisão foi o julgamento do Supremo Tribunal Federal, de 05/05/2011, que reconheceu a união estável de pessoas do mesmo sexo como entidade familiar sendo citados também o art. $226, \S 3^{\circ}$, parte final, da CF, o art. 1.726 do Código Civil e as normas gerais da Corregedoria Geral de Justiça do TJSP, que disciplinam o procedimento de conversão da união estável em casamento. A sentença prevê, ainda, que os dois passem a ter o mesmo sobrenome, como acontece em casamentos. $^{262}$

Na comunidade jurídica, a decisão foi recebida com diferentes opiniões:

Para a Dra. Regina Beatriz Tavares da Silva, presidente da Comissão de Direito de Família do Instituto de Advogados de São Paulo:

A homologação precisaria ser amparada por lei, como já ocorreu em outros países. A decisão do STF confere aos companheiros ou às

\footnotetext{
262 Juiz converte em casamento união estável de pessoas do mesmo sexo. Disponível em: imprensatj@tjsp.jus.br. Acesso em 29 jun. 2011.
} 
companheiras os mesmos direitos de uma união estável. Essa decisão não confere o direito de contraírem casamento civil, argumenta. ${ }^{263}$

De acordo com o diretor-presidente da Escola Superior da Magistratura da Associação de Magistrados Brasileiros (AMB), Roberto Barcelar:

O juiz foi à frente do Supremo. "O casamento ainda continua, pela Constituição, entre homem e mulher. Ele está fazendo uma intepretação conforme a Constituição e parte das premissas dela, como fez o STF, mas está indo muito além do que o Supremo foi". Apesar de o casamento não estar previsto na decisão do STF, a medida do juiz não foi equivocada. É uma tendência que vai precisar de muita discussão até que seja redefinida a palavra casamento, que até hoje está vinculada a pessoas de sexo diferente. ${ }^{264}$

O inteiro teor da sentença encontra-se também publicada na Revista JURIS da FAAP, em artigo do professor Rui Carvalho Piva. ${ }^{265}$

Em 27/08/2011, São Paulo faz o primeiro casamento civil direto entre duas mulheres. O Cartório de Registro Civil das Pessoas Naturais da cidade de Hortolândia (SP) oficiou o primeiro casamento civil homossexual direto do Estado de São Paulo. Até então, somente conversões de união estável em casamento haviam sido autorizadas pelo Poder Judiciário do Estado de São Paulo. O pedido do casal recebeu parecer favorável pelo Ministério Público, e foi deferido em 20 de julho de $2011 .^{266}$

Verifica-se que o Judiciário, adotando uma postura mais liberal, após a decisão do Supremo Tribunal Federal, diante da falta de previsão legal, vem assegurando direitos aos casais homoafetivos.

De acordo com os professores Carlos Alberto Dabus Maluf e Adriana Caldas do Rego Freitas Dabus Maluf:

Posicionamo-nos, por via de consequência, no sentido da possibilidade de tratamento análogo à união estável à união entre pessoas do mesmo sexo, mediante alteração legal, pois entendemos que os princípios basilares da composição familiar, valorizados na pós-modernidade, estão presentes: a affectio externada na vontade de constituir família, configurada no estabelecimento de relação pública, contínua e duradoura; a mútua

\footnotetext{
263 Juiz de São Paulo autoriza que dois homens se tornem oficialmente casados. Disponível em: www.aasp.org.br/aasp/imprensa/clipping/cli_noticia.asp?idnot=10137. Acesso em 28 jun. 2011.

264 Juiz de São Paulo autoriza que dois homens se tornem oficialmente casados. Disponível em: Www.aasp.org.br/aasp/imprensa/clipping/cli_noticia.asp?idnot=10137. Acesso em 28 jun. 2011.

${ }^{265}$ PIVA, Rui Carvalho. Decisão judicial converte em casamento a união estável entre duas pessoas do sexo masculino. Revista JURIS da Faculdade de Direito da FAAP. Vol. 5, ano III, 2011, p. 113-116.

266 São Paulo faz primeiro casamento civil direto entre mulheres. Disponível em: http://www.ibdfam.org.br/impressao.php?=clipping\&n=5080. Acesso em 30 ago. 2011.
} 
assistência material e imaterial dos partícipes; a afetividade; o desejo de perpetuar-se, não mais pesando de forma contundente a orientação sexual das partes envolvidas. ${ }^{267}$

O professor Álvaro Villaça Azevedo não descarta a possibilidade da proteção da união homossexual como uma forma de família, entretanto, entende pela impossibilidade de analogia entre a união estável, tal como apresentada na Constituição Federal e no Código Civil, e a união estável homossexual, tal como a vislumbram alguns autores numa visão mais construtivista dos princípios constitucionais e conclui:

Melhor união homoafetiva do que união estável.

Do mesmo modo, ainda que se cogite de mera convivência, no plano fático, entre pessoas do mesmo sexo, não se configura a união estável e sim a união homoafetiva autônoma.

Realmente, desde que foram conferidos efeitos ao concubinato, até o advento da Súmula 380 do Supremo Tribunal Federal, sempre a jurisprudência brasileira teve em mira o par homem e a mulher.

Com a Constituição Federal de 5 de outubro de 1988, ficou bem claro esse posicionamento, de só reconhecer, como entidade familiar, a união estável entre o homem e a mulher, conforme o claríssimo enunciado do $\S$ $3^{\circ}$ do seu art. 226.

Entretanto, o art. 226 não é taxativo em relacionar os modos de constituição de família, sendo mais fácil admitir que, atualmente, a união homoafetiva foi reconhecida no âmbito do Direito de Família, sendo perfeitamente viável incluí-la no rol do art. 226, como uma categoria autônoma. Já disse que o Estado não pode mencionar na Constituição de modo taxativo, como o povo deve constituir sua família. Por essa razão essa relação do art. 226 da Constituição Federal é meramente enunciativa.

Conceito: União homoafetiva ou homossexual é a convivência pública, contínua e duradoura entre duas pessoas do mesmo sexo, com o intuito de constituição de família. ${ }^{268}$

De acordo com o professor Ives Gandra da Silva Martins:

A decisão do Supremo Tribunal Federal que equiparou a união homoafetiva à união estável considerando-a, pois, entidade familiar, constitui flagrante ofensa a diversos dispositivos expressamente consagrados na Constituição Federal. Assim, o que a Suprema Corte denominou "interpretação conforme" foi, em verdade, um acréscimo ao texto da Lei Maior, mediante nítida substituição do Congresso Nacional. 269

${ }^{267}$ MALUF, Carlos Alberto Dabus, MALUF Adriana C. do Rego F. Dabus. Curso de Direito de Família. São Paulo: 2013, p. 425.

${ }^{268}$ AZEVEDO, Álvaro Villaça. União Homoafetiva. Revista Juris da FAAP, vol. 5, ano III, 2011, p. 11.

${ }^{269}$ MARTINS, Ives Gandra da Silva. A disciplina jurídica do homossexualismo. Scientia Ivridica. Revista de Direito Comparado Português e Brasileiro. Tomo LX, № 327 - Set./Dez., 2011, p. 495. 
No sentido de que o reconhecimento de união estável homossexual é orientação do Supremo Tribunal Federal:

TJRS. Apelação Cível No 70035400530, Sétima Câmara Cível, Relator Roberto Carvalho Fraga, data julgamento: 19/10/2011.

Ementa: AÇÃO DE RECONHECIMENTO DE UNIÃO ESTÁVEL HOMOSSEXUAL. ORIENTAÇÃO DO SUPREMO TRIBUNAL FEDERAL. 1. Tendo em vista a orientação traçada pelo Supremo Tribunal Federal, é inequívoco que a união estável homossexual passou a ser amparada pelas regras jurídicas que tutelam as uniões estáveis. 2. Cuidando-se de união homossexual, deve ser partilhado igualitariamente o patrimônio amealhado durante a convivência marital, com aplicação, por analogia, das disposições do regime legal de bens do casamento e que rege também a união estável. 3. No caso, como não existe patrimônio comum e a pretensão é de partilhar o benefício previdenciário concedido à recorrida, a pretensão mostra-se descabida diante do que estabelece o art. 1.659, inc. VII, do Código Civil, restando excluído do regime da comunhão o benefício. Recurso provido, em parte, por maioria. ${ }^{270}$

No sentido da viabilidade jurídica do reconhecimento da união estável entre pessoas do mesmo sexo, tendo em vista o princípio da dignidade da pessoa humana:

REsp 1199667/MT, Relatora: Ministra Nancy Andrighi, Terceira Turma, julgado em 19/05/2011.

Ementa: DIREITO CIVIL. FAMÍLIA AÇÃO DE RECONHECIMENTO DE UNIÃO HOMOAFETIVA POST MORTEM. DIVISÃO DO PATRIMÔNIO ADQUIRIDO AO LONGO DO RELACIONAMENTO. EXISTÊNCIA DE FILHO ADOTADO PELO PARCEIRO FALECIDO. PRESUNÇÃO DE ESFOÇO COMUM.

Embora não haja norma sobre as uniões homoafetivas, tais uniões não podem ser ignoradas seja pelo legislador, seja pelo julgador:

1. Despida de normatividade, a união afetiva constituída entre pessoas de mesmo sexo tem batido às portas do Poder Judiciário ante a necessidade de tutela. Essa circunstância não pode ser ignorada, seja pelo legislador, seja pelo julgador, que devem estar preparados para regular as relações contextualizadas em uma sociedade pós-moderna, com estruturas de convívio cada vez mais complexas, a fim de albergar, na esfera de entidade familiar, os mais diversos arranjos vivenciais.

Reconhecimento como uma das várias modalidades de entidade familiar:

2. Os princípios da igualdade e da dignidade humana, que têm como função principal a promoção da autodeterminação e impõem tratamento igualitário entre as diferentes estruturas de convívio sob o

270 TJRS. Apelação Cível $\quad N^{\circ} \quad 70035400530 . \quad$ Disponível http://www.tjrs.jus.br/busca/search?q=\&entsp=a_politica-site \&wc=2008wc mc=18oe=UTF-8\&ie . Acesso em 05 jul. 2015. 
âmbito do direito de família, justificam o reconhecimento das parcerias afetivas entre homossexuais como mais uma das várias modalidades de entidade familiar.

No Recurso Especial No 1.085.646-RS, de relatoria da Ministra Nancy Andrigui, a segunda seção do Superior Tribunal de Justiça, por unanimidade, em 11/05/2011, reconheceu a dissolução de união homoafetiva cumulada com partilha de bens. A decisão ocorreu no julgamento de um recurso interposto por um homem contra acórdão do TJ/RS que reconheceu a existência de união estável entre ele e um ex-parceiro, determinando a partilha dos bens adquiridos na constância da relação, que durou aproximadamente 10 anos. O recorrente alega que a decisão do Tribunal gaúcho ofende os artigos $1^{\circ}$ e $9^{\circ}$ da Lei 9.278/96, art. 1.363 do $\mathrm{CC} / 16$ e art. 1.723 do $\mathrm{CC} / 02 .^{271}$

REsp 1085646/RS, Relatora Ministra Nancy Andrighi, Segunda Seção, data do julgamento: 11/05/2011.

Ementa: DIREITO CIVIL. FAMÍLIA. AÇÃO DE RECONHECIMENTO E DISSOLUÇÃO DE UNIÃO AFETIVA ENTRE PESSOAS DO MESMO SEXO CUMULADA COM PARTILHA DE BENS E PEDIDO DE ALIMENTOS. PRESUNÇÃO DE ESFORÇO COMUM. ${ }^{272}$

No mesmo sentido, merece atenção o acórdão proferido no Recurso Especial 827.962-RS, de que foi Relator o Ministro João Otávio de Noronha, da $4^{\mathrm{a}}$ Turma do Superior Tribunal de Justiça e julgado no dia 21 de junho de $2011^{273}$ :

Civil. Relação Homossexual. União Estável, Reconhecimento. Emprego da Analogia.

1. A regra do art. $226, \S 3^{\circ}$ da Constituição, que se refere ao reconhecimento da união estável entre homem e mulher, representou a superação da distinção que se fazia anteriormente entre o casamento e as relações de companheirismo. Trata-se de norma inclusiva, de inspiração antidiscriminatória, que não deve ser interpretada como norma excludente e discriminatória, voltada a impedir a aplicação do regime da união estável às relações homoafetivas.

2. É juridicamente possível pedido de reconhecimento de união estável de casal homossexual, uma vez que não há, no ordenamento jurídico brasileiro, vedação explícita ao ajuizamento de demanda com tal propósito. Competência do juízo da vara de família para julgar o pedido.

${ }^{271}$ STJ reconhece a dissolução de união homoafetiva cumulada com partilha de bens. Disponível em: http://www.migalhas.com.br/Quentes/17,MI133719,91041-STJ+reconhece+a+dissolu...

Acesso em 30 jun. 2013.

272 Recurso $\quad \mathrm{N}^{\circ}$ 1085646-RS. Disponível em: http://www.stj.jus.br/SCON/juruisprudencia/doc.jsp?livre=1085646\&\&b=ACOR\&p=true\&t=\&l=10\&i. Acesso em 11 jul. 2015.

273 Recurso $\quad \mathrm{N}^{\circ}$ 8special 827.962-RS. Disponível em: http://stj.jusbrasil.com.br/jurisprudencia/21101223/recurso-especial-resp-827962-rs-2... Acesso em 02 fev. 2014. 
3. Os arts. $4^{\circ}$ e $5^{\circ}$ da Lei de Introdução ao Código Civil autorizam o julgador a reconhecer a união estável entre pessoas do mesmo sexo.

4. A extensão, aos relacionamentos afetivos, dos efeitos jurídicos do regime da união estável aplicável aos casais heterossexuais traduz a corporificação dos princípios constitucionais da igualdade e da dignidade da pessoa humana.

5. A Lei Maria da Penha atribui às uniões homoafetivas o caráter de entidade familiar, ao prever, no seu art. $5^{\circ}$, parágrafo único, que as relações pessoais mencionadas naquele dispositivo independem de orientação sexual.

Solicitação, pelo companheiro de relação homoafetiva, de pensão por morte de servidor público:

REsp 932653/RS, Relator Ministro Celso Limongi (Desembargador convocado do TJ/SP), Sexta Turma, julgado em 16/08/2011.

Ementa: RECURSO ESPECIAL. ADMINISTRATIVO. PENSÃO POR MORTE. SERVIDOR PÚBLICO. COMPANHEIRO. RELAÇÃO HOMOAFETIVA. ART. 217, I, C ,DA LEI Nº 8.112/90.

- A regulamentação das famílias homoafetivas é medida que se impõe no atual cenário social, não podendo o Poder Judiciário, nesse momento, furtar-se a oferecer as proteções legais que tais relações demandam, porquanto são geradoras de importantes efeitos afetivos e patrimoniais na vida de muitos cidadãos.

-No presente caso, ficou devidamente comprovada a união estável entre o autor, ora recorrido, e seu falecido companheiro, servidor público, regido pela Lei 8.112/90, motivo pelo qual, agiram bem as instâncias ordinárias ao conceder a pretendida pensão por morte, nos termos do art. 217, I, "c" do referido Estatuto.

- Além do mais, o próprio INSS, gestor do Regime Geral de Previdência Social, há mais de dez anos, vêm reconhecendo os parceiros homossexuais como beneficiários da Previdência, pelo que não há como negar o mesmo direito aos companheiros homossexuais de servidor público, equiparando-os à tradicional União Estável formada por homem e mulher.

- Acrescento, ainda, que a mais recente norma editada pela Receita Federal (agosto de 2010) garantiu o direito de Contribuintes do Imposto de Renda de Pessoa Física de incluírem parceiros homossexuais como seus dependentes na Declaração, o que revela não haver mais espaço para renegar os direitos provenientes das relações homoafetivas, e que só contribuirá para tornar a nossa Sociedade mais justa, humana e democrática, ideal tão presente na Constituição Federal. ${ }^{274}$

O Supremo Tribunal Federal, em 16/08/2011, de relatoria do Ministro Celso de Mello, no Recurso Extraordinário RE 477554 AgR/MG, reconheceu a legitimidade

274 Recurso Especial $\quad N^{\circ} \quad 932653 / R S . \quad$ Disponível em: http://www.stj.jus.br/SCON/jurisprudencia/doc.jsp?livre=1199667\&\&b=ACOR\&p=TR... Acesso em 06 jul. 2015. 
constitucional do reconhecimento e qualificação da união estável homoafetvia como entidade familiar.

RE 477554 AgR/MG - Minas Gerais, AG.REG no Recurso Extraordinário, Relator Ministro Celso de Mello, julgamento em 16/08/2011, Segunda Turma:

EMENTA: UNIÃO CIVIL ENTRE PESSOAS DO MESMO SEXO ALTA RELEVÂNCIA SOCIAL E JURÍDICO-CONSTITUCIONAL DA QUESTÃO PERTINENTE ÀS UNIÕES HOMOAFETIVAS LEGITIMIDADE CONSTITUCIONAL DO RECONHECIMENTO E QUALIFICAÇÃO DA UNIÃO ESTÁVEL HOMOAFTEVIA COMO ENTIDADE FAMILIAR: POSIÇÃO CONSAGRADA NA JURISPRUDÊNCIA DO SUPREMO TRIBUNAL FEDERAL (ADPF 132/RJ E ADI 4277/DF) - O AFETO COMO VALOR JURÍDICO IMPREGNADO DE NATUREZA CONSTITUCIONAL: A VALORIZAÇÃO DESSE NOVO PARADIGMA COMO NÚCLEO CONFORMADOR DO CONCEITO DE FAMÍLIA - O DIREITO À BUSCA DA FELICIDADE, VERDADEIRO POSTULADO CONSTITUCIONAL IMPLÍCITO E EXPRESSÃO DE UMA IDEIAFORÇA QUE DERIVA DO PRINCÍPIO DA ESSENCIAL DIGNIDADE DA PESSOA HUMANA - ALGUNS PRECEDENTES DO SUPREMO TRIBUNAL FEDERAL E DA SUPREMA CORTE AMERICANA SOBRE O DIREITO FUNDAMENTAL À BUSCA DA FELICDADE - PRINCÍPIOS DE YOGYAKARTA (2006): DIREITO DE QUALQUER PESSOA DE CONSTITUIR FAMÍLIA, INDEPENDENTEMENTE DE SUA ORIENTAÇÃO SEXUAL OU IDENTIDADE DE GÊNERO - DIREITO DO COMPANHEIRO, NA UNIÃO ESTÁVEL HOMOAFETIVA, À PERCEPÇÃO DO BENEFÍCIO DA PENSÃO POR MORTE DE SEU PARCEIRO, DESDE QUE OBSERVADOS OS REQUISITOS DO ART. 1.723 DO CÓDIGO CIVIL - O ART. 226, $\S 3^{\circ}$, DA LEI FUNDAMENTAL CONSTITUI TÍPICA NORMA DE INCLUSÃO - A FUNÇÃO CONTRAJAMORITÁRIA DO SUPREMO TRIBUNAL FEDERAL NO ESTADO DEMOCRÁTICO DE DIREITO - A PROTEÇÃO DAS MINORIAIS ANALISADA NA PERSPECTIVA DE UMA CONCEPÇAO MATEIRAL DE DEMOCRACIA CONSTITUCIONAL - DO DEVER CONSTITUCIONAL DO ESTADO DE IMPEDIR (E, ATÉ MESMO, DE PUNIR) "QUALQUER DISCRIMINAÇÃO ATENTATÓRIA DOS DIREITOS E LIBERDADES FUNDAMENTAIS" (CF, ART. $5^{\circ}$, XLI) - FORÇA NORMATIVA DOS PRINCÍPIOS CONSTITUCIONAIS E O FORTALECIMENTO DA JURISDIÇÃO CONSTITUCIONAL: ELEMENTOS QUE COMPÕEM O MARCO DOUTRINÁRIO QUE CONFERE SUPORTE TEÓRICO AO NEOCONSTITUCIONALISMO - RECURSO DE AGRAVO IMPROVIDO. NINGUÉM PODE SER PRIVADO DE SEUS DIREITOS EM RAZÃO DE SUA ORIENTAÇÃO SEXUAL. ${ }^{275}$

275 RE $477554 \quad$ AGR/MG. Disponível em: http://www.stf.jus.br/portal/jurisprudencia/listarJurisprudenciaDetalhe.asp?s1=000178... Acesso em 04 jul. 2015. 
O Tribunal Regional da $5^{\text {a }}$ Região, em 09/08/2013, reconheceu a um sargento homossexual do Exército Brasileiro, o direito à inclusão do seu companheiro no CABDEN-FUSEX- Cadastro de Beneficiário Dependentes do Fundo de Saúde do Exército.

Tribunal Regional Federal $-5^{\text {a }}$ Região, Apelação Cível $\mathbf{N}^{\mathbf{o}}$ 08002607720124058300, Terceira Turma, data do julgamento: 18/07/2013.

EMENTA: CONSTITUCIONAL. ADMINISTRATIVO. SERVIDOR PÚBLICO. RELAÇÃO HOMOAFETIVA. COMPANHEIRO. DEPENDÊNCIA ECONÔMICA. UNIÃO ESTÁVEL. COMPROVAÇÃO. ART. 226, PARÁGRAFO $3^{\circ}$. CF/88. LEI $\mathrm{N}^{\circ}$ 8.112/90. INSTRUÇÃO NORMATIVA INSS-C N 25.

1. A Sociedade de fato existente em uma relação homoafetiva merece tratamento isonômico ao dispensado às uniões heterossexuais em respeito aos princípios constitucionais da igualdade, da dignidade da pessoa humana e da promoção do bem de todos, sem preconceito ou discriminação.

2. A inexistência de regra que contemple a possibilidade da percepção de benefício previdenciário por companheiro em relação homoafetiva de servidor público não pode ser considerada como obstáculo para o reconhecimento da existência de um fato para o qual a proteção jurídica é reclamada.

3. Mesmo que se pudesse entender que a Lei $\mathrm{n}^{\circ}$ 8.112/90, não contemplaria a situação versada nos autos, o que importaria em se incorrer em inaceitável e antijurídica discriminação sexual, se o sistema geral de previdência do País cogita de hipótese similar, em observância ao princípio isonômico, deve-se aplicar aos servidores públicos federais, por analogia, o disposto na Instrução Normativa INSS-DC n ${ }^{\circ} 25$.

4. Robusta documentação acostada aos autos, no que se demonstra a existência de escritura pública declaratória, no $2^{\circ}$ Ofício de Notas do Recife, dando ciência da união homoafetiva entre J. e A.; bem como, extrato de publicação, do processo $\mathrm{n}^{\circ}$ 0009140-90.2012.8.17.0001, em 05/07/2012, sentença $n^{\circ}$ 2012/00403, em Ação Declaratória de Existência de União Estável, julgada procedente. ${ }^{276}$

O reconhecimento judicial de união homoafetiva é dotado de interesse de agir, pois a escritura pública de declaração de sociedade de fato não se presta à consecução dos mesmos efeitos decorrentes da declaração de existência de uma entidade familiar:

REsp 1370542/DF, Relatora Ministra Nancy Andrighi, Terceira Turma, julgado em: 05/11/2013.

Ementa: RECURSO ESPECIAL. DIREITO DE FAMÍLIA E PROCESSO CIVIL. AÇÃO DECLARATÓRIA DE UNIÃO

$276 \quad$ Apelação $\quad$ Cível $\quad N^{o} \quad 08002607720124058300 . \quad$ Disponível http://www.trf5.jus.br/Jurisprudencia/JurisServlet?op=exibir\&tipo=1 Acesso em 11 jul. 2015. 
HOMOAFETIVA. PRÉVIA FORMALIZAÇÃO DE ESCRITURA PÚBLICA DE DECLARAÇÃO DE SOCIEDADE DE FATO PARA EFEITOS PATRIMONIAIS. POSSÍVEIS EFEITOS SECUNDÁRIOS ATINENTES À EMISSÃO DE VISTO DEFINITIVO DE PERMANÊNCIA DE UM DOS AUTORES EM TERRITÓRIO BRASILEIRO. INTERESSE DE AGIR. EXISTÊNCIA. ARTIGOS ANALISADOS: $4^{\circ}$, I e 861 a 866, do CPC.

2 Discute-se a existência de interesse de agir na pretensão de se ver declarada a união estável homoafetiva, em especial por ter havido prévia formalização pelos recorrentes de escritura pública de declaração de sociedade de fato para efeitos patrimoniais e o possível interesse secundário de assegurar, com o reconhecimento da união, a emissão de visto definitivo de permanência do recorrente estrangeiro em território nacional.

3 A pretensão expressamente manifestada de reconhecimento judicial de união estável homoafetiva é dotada de interesse de agir, não se prestando a escritura pública de declaração de sociedade de fato para efeitos patrimoniais - anteriormente firmada pelos recorrentes- à consecução dos mesmos efeitos decorrentes da declaração de existência de uma entidade familiar. ${ }^{277}$

Sobre o reconhecimento de união homoafetiva "post mortem":

Embargos de Declaração no Recurso Especial - Edcl no REsp 633713/RS, Relator Ministro Ricardo Villas Bôas Cueva, Terceira Turma, data do julgamento: 11/02/2014.

Ementa: EMBARGOS DE DECLARAÇÃO NO RECURSO ESPECIAL. CARÁTER INFRINGENTE. POSSIBILIDADE. EXCEPCIONALIDADE. CABIMENTO. DIREITO CIVIL. FAMÍLIA. AÇÃO DE RECONHECIMENTO DE UNIÃO HOMOAFETIVA POST MORTEM. EQUIPARAÇÃO À UNIÃO ESTÁVEL HETEROAFETIVA. REQUISITOS. SÚMULA N ${ }^{\circ}$ 7/STJ. DIVISÃO DO PATRIMÔNIO ADQUIRIDO AO LONGO DO RELACIONAMENTO. PRESUNÇÃO DE ESFORÇO COMUM. DESNECESSIDADE. PRECEDENTES DO STJ E DO STF. EMBARGOS ACOLHIDOS COM EFEITOS MODIFICATIVOS. RECURSO ESPECIAL DESPROVIDO.

Reconhecimento da união homoafetiva e direito real de habitação:

REsp 1204425/MG, Relator Ministro Luis Felipe Salomão, Quarta Turma, data do julgamento 11/02/2014.

Ementa: DIREITO DE FAMÍLIA, SUCESSÕES E PROCESSUAL CIVIL. UNIÃO HOMOAFETIVA. RECONHECIMENTO. SUCESSÃO REGIDA PELAS LEIS N. 8.971/1994 E N. 9.278/1996. AUSÊNCIA DE ASCENDENTES E DESCENDENTES DO DE CUJUS. PEDIDO INICIAL QUE SE LIMITA A DIREITO REAL DE HABITAÇÃO SOBRE O IMÓVEL RESIDENCIAL. SENTENÇA QUE O ACOLHE NOS MESMOS TERMOS. RECURSO DE APELAÇÃO,

277 Recurso Especial $\quad \mathrm{N}^{\circ} \quad$ 1370542/DF. Disponível $\quad \mathrm{em}$ http://www.stj.jus.br/SCONjurisprudencia/doc.jsp?tipo visualizacao=RESUMO\&livre $=1370542 \& b=\ldots$

Acesso em 06 jul. 2015. 
INEXISTÊNCIA. PROPRIEDADE PLENA. PEDIDO REALIZADO EM GRAU DE RECURSO ESPECIAL. IMPOSSIBILIDADE.

Neste recurso fica clara a opinião do Superior Tribunal de Justiça e do Supremo Tribunal Federal com relação à viabilidade jurídica de uniões estáveis formadas por companheiros do mesmo sexo. No mesmo sentido o reconhecimento da juridicidade do casamento entre pessoas do mesmo sexo.

1. No Superior Tribunal e no Supremo Tribunal Federal, são reiterados os julgados dando conta da viabilidade jurídica de uniões estáveis formadas por companheiros do mesmo sexo. No âmbito desta Casa, reconheceu-se, inclusive, a juridicidade do casamento entre pessoas do mesmo sexo (REsp 1.183.78/RS, Rel. Ministro Luis Felipe Salomão, Quarta Turma, julgado em 25/10/2011), tendo sido essa orientação incorporada pelo Conselho Nacional de Justiça na Resolução n. 175/2013. ${ }^{278}$

Interessante julgado do Superior Tribunal de Justiça reconheceu direito a alimentos em união entre pessoas do mesmo sexo.

Recurso Especial $\mathbf{N}^{\mathbf{0}}$ 1.302.467-SP, Relator Ministro Luis Felipe Salomão, Quarta Turma, Julgado em 03/03/2015.

Ementa: DIREITO DE FAMÍLIA E PROCESSUAL CIVIL. UNIÃO ENTRE PESSOAS DO MESMO SEXO (HOMOAFETIVA) ROMPIDA. DIREITO A ALIMENTOS. POSSIBILIDADE. ART. 1.694 DO CC/02. PROTEÇÃO DO COMPANHEIRO EM SITUAÇÃO PRECÁRIA E DE VULNERABILIDADE. ORIENTAÇÃO PRINCIPIOLÓGICA CONFERIDA PELO STF NO JULGAMENTO DA ADPF N. 132/RJ E DA ADI N. 4277/DF. ALIMENTOS PROVISIONAIS. ART. 852 CPC. PREENCHIMENTO DOS REQUISITOS. ANÁLISE PELA INSTÂNCIA DE ORIGEM. ${ }^{279}$

\subsection{Conclusão}

Inicialmente, quando o pedido de reconhecimento das uniões homoafetivas chegava ao Poder Judiciário, entendia-se que havia a impossibilidade jurídica do pedido.

\footnotetext{
${ }^{278}$ Recurso Especial N. 1204425/MG, Relator Ministro Luis Felipe Salomão, Quarta Turma, julgado em 11/02/2014. Disponível em: http://www.sti.jus.br/SCON/jurisprudencia/doc.jsp?livre=1204425\&\&b=ACOR\&p=tr... Acesso em 06 jul. 2015.

279 Recurso Especial $\mathrm{N}^{\circ}$ 1302467/SP. Disponível em: http://www.stj.jus.br/SCON/jurisprudencia/doc.jsp?livre=1302467\&\&b=ACOR\&p=true\&t=\&l=10\&i Acesso em 08 jul. 2015.
} 
Posteriormente, a essas uniões foi reconhecido apenas o direito patrimonial, sendo caracterizadas como sociedade de fato, pois era grande a resistência em aceitar que formavam uma família.

Aos poucos, várias decisões garantiram direitos previdenciários aos casais homossexuais, mostrando que essa categoria de indivíduos merecia tratamento igualitário e se referindo à sociedade de fato como uma forma de status semelhante às uniões heterossexuais.

O professor Álvaro Villaça Azevedo sempre deixou claro que as uniões entre pessoas do mesmo sexo, mesmo que preenchessem os requisitos da união estável heterossexual, não configurariam o instituto da união estável, pois, desde que foram considerados efeitos ao concubinato até o advento da Súmula 380 do Supremo Tribunal Federal, sempre a jurisprudência brasileira teve em mira o par andrógino, o homem e a mulher. Com a Constituição Federal de 1988 ficou bem claro esse posicionamento de só reconhecer como entidade familiar a união estável entre o homem e a mulher, conforme o claríssimo enunciado do $\S 3^{\circ}$ do seu art. 226.

No ano de 1999, o Tribunal de Justiça do Rio Grande do Sul definiu a competência das Varas da Família para apreciar as uniões de pessoas do mesmo sexo. Esse foi o primeiro grande marco que mudou os rumos da jurisprudência.

Sobre a possibilidade de reconhecimento da união homossexual como entidade familiar, é paradigmática a decisão da $7^{\mathrm{a}}$ Câmara Cível do Tribunal do Rio Grande do Sul, na Apelação Cível № 70001388982, relatada pelo Desembargador José Carlos Teixeira Georgis, julgada em 14/03/2011, que reconheceu a partilha do patrimônio havido na constância do relacionamento como o da união estável.

Porém, boa parte da doutrina entendia que a união sexual entre pessoas do mesmo sexo, contínua, pública e duradoura não caracterizaria uma entidade familiar. Rainer Czajkwski em seu livro "União Livre”, de 2002, afirmou que não configuravam uma entidade familiar porque "não formavam um núcleo de procriação humana e de educação de futuros cidadãos".

No entanto, várias decisões dos Tribunais em vários Estados passaram a reconhecer as uniões homoafetivas tendo em vista os princípios constitucionais da 
dignidade da pessoa humana e da igualdade. Por ausência de regramento específico, aplicavam-se analogicamente as regras da união estável.

O reconhecimento da possibilidade jurídica da união estável homoafetiva por analogia é visto de forma clara na decisão do REsp $\mathrm{N}^{\circ}$ 820.475-RJ, dada pela Quarta Turma do Superior Tribunal de Justiça de relatoria do Ministro Antonio de Pádua Ribeiro, julgado em 02/09/2008.

Finalmente, em 05 de maio de 2011, o Supremo Tribunal Federal, em votação unânime, ao julgar a ADI n 4277/DF e a ADPF n 132/RJ reconheceu a união homoafetiva como entidade familiar. Assim ao interpretar o art. 1.723 do Código Civil conforme a Constituição Federal garantiu aos parceiros homossexuais os mesmos direitos e deveres da união estável, entendida a união homoafetiva como sinônimo perfeito de família.

Da análise dos votos dos dez Ministros do Supremo Tribunal Federal, podemos retirar considerações muito importantes:

Ministro Ayres Brito:

- A preferência sexual se põe como direta emanação do princípio da dignidade da pessoa humana (inciso III, do art. $1^{\circ}$ da $\mathrm{CF}$ );

- Com relação à família a Constituição Federal não faz a menor diferenciação entre a família que se forma por sujeitos heteroafetivos e a que se constitui por pessoas de inclinação homoafetiva;

- A terminologia "entidade familiar" não significa algo diferente de 'família", pois não há hierarquia ou diferença de qualidade jurídica entre as duas formas de constituição de um novo núcleo doméstico;

- Tanto no casamento quanto na união estável nenhuma referência é feita à interdição, ou à possibilidade de protagonização por pessoas do mesmo sexo. Inteligência que se robustece com a proposição de que não se proíbe nada a ninguém senão em face de um direito ou de proteção de um interesse de outrem;

- Quanto à adoção, a Constituição Federal não abre distinção entre adotante "homo ou "heteroafetivo".

Ministro Luiz Fux: 
- A homossexualidade é um fato da vida;

- A homossexualidade é uma orientação e não uma opção sexual;

- A homossexualidade não constitui doença, desvio ou distúrbio mental, mas uma característica da personalidade do indivíduo;

- Não há qualquer inconstitucionalidade ou ilegalidade no estabelecimento de uniões homoafetivas. Não existe, no direito brasileiro, vedação às uniões homoafetivas, haja vista, sobretudo, a reserva de lei instituída pelo art. 5 , inciso II, da Constituição de 1988 para a vedação de quaisquer condutas aos indivíduos;

- O direito segue a evolução social, estabelecendo normas para a disciplina dos fenômenos já postos. Não é diferente neste caso: o ato de constituição da união homoafetiva existe, ocorre e gera efeitos juridicamente relevantes que, portanto, merecem tratamento pelo direito;

- O que distingue do ponto de vista ontológico as uniões estáveis heteroafetivas das uniões homoafetivas? Nada as distingue. Assim inexistindo razão suficiente para o tratamento jurídico diferenciado, impõe-se o tratamento idêntico;

- Ignorar a existência e a validade jurídica das uniões homoafetivas é o mesmo que as por em situação de injustificada desvantagem em relação às uniões estáveis heterossexuais;

- O silêncio legislativo sobre as uniões homoafetivas nada mais é do que um juízo moral sobre a realização individual pela expressão de sua orientação sexual. Na verdade, significa rejeição;

- A questão do reconhecimento também toca o tema da segurança jurídica;

- Não se há de objetar que o art. $226, \S 3^{\circ}$ da CF constituirá obstáculo à equiparação das uniões homoafetivas às uniões estáveis heterossexuais, por força da previsão literal "entre homem e mulher". A norma é de inclusão. Seria perverso conferir à norma de cunho indiscutivelmente emancipatório intepretação restritiva. A mesma lógica há de se estender ao art. 1.723 do Código Civil.

Ministra Cármen Lúcia:

- O Direito existe para a vida e não a vida para o Direito; 
- Contra todas as formas de preconceito há o Direito Constitucional.

Ministro Lewandowski:

- A união entre pessoas do mesmo sexo é um quarto gênero de entidade familiar não previsto no rol do art. 226 da Carta Magna;

- Porém, o rol do art. 226 da $\mathrm{CF}$ não é taxativo, mas meramente exemplificativo, dada a natureza aberta das normas constitucionais;

- O que se pretende, ao empregar o instrumento metodológico da integração, não é, à evidência, substituir a vontade do constituinte por outra arbitrariamente escolhida, mas apenas, tendo em conta a existência de um vácuo normativo, procurar reger uma realidade social superveniente a essa vontade, ainda que de forma provisória, ou seja, até que o Parlamento lhe dê o adequado tratamento legislativo;

- Não se está aqui a reconhecer uma "união estável homoafetiva”, por interpretação extensiva do $\S 3^{\circ}$ do art. 226, mas uma "união homoafetiva estável" mediante um processo de integração analógica;

- Cuida-se de uma entidade familiar que embora não esteja expressamente prevista no art. 226, precisa ter a sua existência reconhecida pelo Direito;

- Reconhecida a união homoafetiva como entidade familiar, aplicam-se a ela as regras do instituto que lhe é mais próximo, qual seja, a união estável heterossexual, mas apenas nos aspectos em que são assemelhados, descartando-se aqueles que são próprios da relação entre pessoas de sexo distinto.

Ministro Joaquim Barbosa:

- As Cortes Supremas e Constitucionais devem fazer a ponte entre o mundo do Direito e a Sociedade;

- O reconhecimento dos direitos oriundos de uniões homoafetivas encontra fundamento em todos os dispositivos constitucionais que estabelecem a proteção dos direitos fundamentais: no princípio da dignidade da pessoa humana, no princípio da igualdade e da não-discriminação;

Ministro Gilmar Mendes: 
- Apesar de o Poder Legislativo debruçar-se sobre o tema há mais de 15 anos, até hoje não conseguiu chegar a consenso básico para aprovação de qualquer regulamentação;

- A demora em aprovar legislação gera nos interessados angústia natural e um sentimento de desproteção, para os quais buscam solução no Judiciário;

- Mas, não estamos a falar apenas da falta de uma disciplina legislativa, mas do reconhecimento do direito de minorias, de direitos fundamentais básicos. E, nesse ponto, não se trata de ativismo judicial, mas de cumprimento da própria essência da jurisdição constitucional, de acordo com o art. $5^{\circ}$, inciso XLI, da Constituição ao determinar que "a lei punirá qualquer discriminação atentatória dos direitos e liberdade fundamentais";

- Limito-me a reconhecer a existência da união entre pessoas do mesmo sexo, por fundamentos jurídicos próprios e distintos daqueles explicitados pelo Ministro Ayres Brito, e com suporte na teoria do pensamento possível determinar a aplicação de um modelo de proteção semelhante no caso, o que trata da união estável - naquilo que for cabível, nos termos da fundamentação aqui apresentada, sem me pronunciar sobre outros desdobramentos;

- Destaco que a decisão do Supremo não significa óbice à atuação do Poder Legislativo. Trata-se de um estímulo institucional para que, de fato, as mais diversas situações jurídicas que envolvem a união entre pessoas do mesmo sexo venham a ser disciplinadas.

A Ministra Ellen Gracie finalizou seu voto dizendo que:

- O Supremo "restitui aos homossexuais o respeito que merecem, reconhece seus direitos, restaura a sua dignidade, afirma a sua identidade e restaura a sua liberdade".

Ministro Marco Aurélio:

- O cerne da questão em debate é saber se a convivência pública, duradoura e com ânimo de formar família, por pessoas de sexo igual deve ser admitida como entidade familiar à luz da Lei Maior, considerada a 
omissão legislativa. Em caso positivo, cabe a aplicação do regime previsto no artigo 1.723 do Código Civil de 2002?;

- Especificamente quanto à religião, não podem a fé e as orientações morais dela decorrentes ser impostas a quem quer que seja, e por quem quer que seja;

- As garantias de liberdade religiosa e do Estado laico impedem que concepções morais religiosas guiem o tratamento estatal dispensado a direitos fundamentais, tais como o direito à dignidade da pessoa humana, $\mathrm{o}$ direito à autodeterminação, o direito à privacidade e o direito à liberdade de orientação sexual;

- Como é cediço, compete aos intérpretes efetuar a filtragem constitucional dos institutos previstos na legislação infraconstitucional. Esse fenômeno denominado "constitucionalização do Direito" revela que não podemos nos ater ao dogmatismo ultrapassado, que então prevalecia no Direito Civil;

- Relegar as uniões homoafetivas à disciplina da sociedade de fato é não reconhecer essa modificação paradigmática no Direito Civil levada a cabo pela Constituição da República;

- De nada adiantaria a positivação de direitos na Constituição, se eles fossem lidos em conformidade com a opinião pública dominante;

- Inexiste vedação constitucional à aplicação do regime da união estável a essas uniões, não se podendo vislumbrar silêncio eloquente em virtude da redação do $\S 3^{\circ}$ do art. 226;

- Nesse contexto, a literalidade do artigo 1.723 do Código Civil está muito aquém do que consagrado pela Carta de 1988. Não retrata fielmente o propósito de reconhecer direitos a grupos minoritários.

Ministro Celso de Melo:

- Os adversários da possibilidade de reconhecimento da união estável entre pessoas do mesmo sexo invocam a redação do art. 226, $\S 3^{\circ}$ da Constituição Federal, pois tal preceito teria barrado a possibilidade do reconhecimento da união homoafetiva no Brasil, enquanto não fosse 
aprovada emenda alterando o texto constitucional. $\mathrm{O}$ argumento que se apega apenas na literalidade do texto não procede;

- Os princípios constitucionais são os vetores que apontam no sentido de que a exegese das normas setoriais da Constituição - como o nosso $\S 3^{\circ}$ do art. 226 - deve buscar a inclusão e não a exclusão dos estigmatizados; a emancipação dos grupos vulneráveis e não a perenização do preconceito e da desigualdade;

- Não é ativismo judicial. Na realidade, o Supremo Tribunal Federal, ao suprir as omissões inconstitucionais dos órgãos estatais e ao adotar medidas que objetivem restaurar a Constituição violada pela inércia dos poderes do Estado, nada mais fez senão cumprir a sua missão constitucional e demonstrar, com esse gesto, o respeito incondicional que tem pela autoridade da Lei Fundamental da República.

Ministro Cezar Peluso:

- Começo por dizer que teria alguma dificuldade de ordem teórica para conhecer das demandas como ações diretas de inconstitucionalidade, não fosse o fato de que o disposto no artigo 1.723 do Código Civil não é reprodução estrita do artigo $226, \S 3^{\circ}$ da Constituição Federal. Se assim fosse, estaríamos, sim, diante de um caso de pura interpretação constitucional, que não poderia ser objeto de ação de inconstitucionalidade sob pretexto de que teríamos que interpretar a própria constituição de acordo com a Constituição;

- Mas a diversidade de redação das normas permite a decisão da Corte de conhecer das demandas de tal modo que é possível enxergar o disposto no artigo 1.723 como preceito suscetível de revisão à luz do art. $226, \S 3^{\circ}$, e de outras normas constitucionais;

- As normas aplicáveis à solução da questão posta são as que se aplicam à união estável entre o homem e a mulher. Mas nem todas, porque não se trata de situações absolutamente idênticas. E, portanto, é preciso respeitar aquilo que cada instituição, em si, tem de particular, não apenas por sua natureza extrajurídica, mas também pela própria natureza normativa de cada qual; 
- Há, a partir desse julgamento, uma convocação ao Poder Legislativo para que assuma a tarefa de regulamentar esta equiparação.

Verifica-se, portanto, que apesar de unânimes as decisões reconhecendo a união entre parceiros do mesmo sexo como uma nova forma de entidade familiar, os Ministros Ricardo Levandowski, Gilmar Mendes e Cezar Peluso convergiram no particular entendimento da impossibilidade de ortodoxo enquadramento da união homoafetiva nas espécies de família constitucionalmente estabelecidas.

O entendimento dos três Ministros citados acima abre espaço ao Poder Legislativo para aplicar um modelo de proteção semelhante ao da união estável, naquilo que for cabível, respeitando o que cada instituição tem em si de particular.

Entendemos que os limites entre o Poder Judiciário o Poder Legislativo não foram ultrapassados, porque o Supremo Tribunal Federal nada mais fez do que cumprir sua missão constitucional demonstrando o respeito incondicional que tem pela autoridade da Lei Fundamental da República, pois de nada adiantaria a positivação de direitos na Constituição, se eles fossem lidos em conformidade com a opinião pública dominante.

Para o ministro Teori Zavascki, do Supremo Tribunal Federal, o que hoje se convencionou chamar de ativismo judicial é uma forma de estabelecer limites nas relações entre o Judiciário e o Legislativo. É o princípio constitucional da separação dos poderes, responsável por ditar qual deve ser a distância entre julgadores e legisladores. O ministro também explicou que o ativismo judicial também envolve o princípio constitucional da inafastabilidade do monopólio da função jurisdicional, segundo o qual a lei não pode excluir da apreciação do Judiciário qualquer lesão ou ameaça a direito. ${ }^{280}$

Sobre o valor da jurisprudência dos tribunais no direito brasileiro, o professor Tercio Sampaio Ferraz Junior, em artigo publicado originalmente na página "Tendências e Debates", da Folha de São Paulo, no dia 29/09/2014, afirma que atualmente, a sensação é que há uma espécie de crise do paradigma do direito legislado e codificado.

280 Ativismo judicial é o que separa Legislativo do Judiciário. Disponível em: http://www.conjur.com.br/2014-abr-28/teori-ativismo-judicia-separa-legislativo-judic... Acesso em 29 abr. 2014. 
Até recentemente, v.g., um livro de direito constitucional não fazia referência à jurisprudência. Hoje, os manuais são repletos de menções a ela. A consequência disso é que passamos da centralidade da lei para a da jurisdição. ${ }^{281}$

Em palestra sobre o chamado "Ativismo judicial e seus limites no Brasil", no seminário “25 Anos da Constituição Federal de 1988”, em junho de 2013, o jurista José Afonso da Silva destacou o reconhecimento da união estável entre pessoas do mesmo sexo, pelo Supremo Tribunal Federal (STF), como um dos casos mais recentes e expressivos nessa área no Brasil.

"O ativismo judicial é uma forma de interpretação constitucional criativa, que pode chegar até a constitucionalização de direitos, pelo que se pode dizer que se trata de uma forma especial de interpretação também construtiva."

$\mathrm{O}$ ativismo judicial tem produzido tanto no Brasil, quanto nos Estados Unidos e países europeus, a constitucionalização de direitos de caráter social e muitas vezes enriquecedores para a democracia.

Citando seu colega constitucionalista e ministro nomeado do Supremo Tribunal Federal, Luis Roberto Barroso, o professor José Afonso da Silva lembrou que "ele expôs que num regime democrático prevalece a posição da maioria representada pelo Poder Legislativo, ensinando que, sempre que o Legislativo dispõe sobre o Direito, o Poder Judiciário deve seguir aquela decisão.

Concluindo o professor José Afonso da Silva disse: "Logo, o Judiciário só pode avançar, só deve avançar, quando o Legislativo não regulou inteiramente ou regulou deficientemente a matéria”.

“Em síntese, onde há decisão política, respeita-se; onde não há decisão política, é preciso resolver o problema; mais que isso, onde haja um direito fundamental e de sua maioria, o Judiciário precisa intervir.,"282

Após o julgamento em 5 de maio de 2011, pelo Supremo Tribunal Federal das duas ações, ADPF 132/RJ e ADI 4277/DF, ocorreram inúmeros pedidos de

\footnotetext{
${ }^{281}$ FERRAZ JUNIOR, Tercio Sampaio. Jurisprudência passou a ter mais importância que a própria lei. Disponível em: http://www.conjur.com.br/2014-set-29/jurisprudencia-passou-importancia-propria-lei?... Acesso em 30 set. 2014.

282 José Afonso da Silva aborda o ativismo judicial em seminário da OAB. Disponível em: http://www.oab.org.br/util/print/25758?print=Noticia. Acesso em 13 jun. 2013.
} 
reconhecimento de união homoafetiva, conversão de união homoafetiva em casamento e habilitação direta para o casamento.

Analisando as decisões judiciais após o julgamento das duas ações, pode-se dizer que, de maneira geral, o Poder Judiciário entendeu que deveriam ser aplicadas as mesmas regras da união estável às uniões homoafetivas.

Com relação à doutrina, a maioria se posicionou no sentido da possibilidade de que a união homoafetiva tivesse tratamento análogo à união estável. O professor Álvaro Villaça Azevedo não descarta a possibilidade da proteção da união homossexual como uma forma de família, entretanto, entende pela impossibilidade de analogia entre a união estável, tal como apresentada na Constituição Federal e no Código Civil, e a união estável homossexual, tal como a vislumbram alguns autores numa visão mais construtivista dos princípios constitucionais.

A maioria da doutrina entende que há a necessidade de legislação infraconstitucional a respeito do tema, pois como observa o professor Álvaro Villaça Azevedo o que temos hoje para a proteção dos pares homossexuais é a união estável atípica.

Também entendemos que haja a necessidade de uma legislação infraconstitucional, mas vislumbramos uma legislação para a união homoafetiva com os mesmos efeitos da união estável, conforme vêm se efetivando tais uniões há quatro anos por meio do Poder Judiciário. Logo, somos a favor dos mesmos direitos e deveres embora com nomes diferentes por se tratar de outra espécie de entidade familiar.

Quanto à mudança na Constituição Federal, para acolher a união homoafetiva, esta não se faz necessária tendo em vista que o rol do artigo 226 da Constituição Federal não é taxativo, mas meramente exemplificativo, dada a natureza aberta das normas constitucionais. 


\section{O CASAMENTO CIVIL E A UNIÃO HOMOAFETIVA}

Em nossa legislação não há proibição expressa com relação ao casamento entre pessoas do mesmo sexo, porém, em inúmeros artigos, fica claro o binômio homem e mulher.

Nossa jurisprudência e nossa doutrina, desde os mais longínquos tempos, com relação ao casamento entre pessoas do mesmo sexo vêm se modificando. Num primeiro momento, verificou-se o entendimento de que casamento contraído entre duas pessoas do mesmo sexo era casamento inexistente. Nos dias atuais, após a Resolução № 175, do Conselho Nacional de Justiça, de 14/05/2013, é vedada às autoridades competentes a recusa de habilitação, celebração de casamento civil ou de conversão de união estável em casamento entre pessoas de mesmo sexo, embora continue não havendo legislação a respeito do tema.

Resta, então, uma pergunta: A teoria do casamento inexistente foi abalada? Passemos então ao estudo sobre a evolução do conceito de casamento e a verificação de como tais mudanças alteraram, ou não, a teoria da inexistência do casamento.

\subsection{Casamento no direito romano}

Para os romanos, no direito romano clássico, o negócio jurídico era válido ou nulo, sendo que negócio jurídico inexistente era tido como nulo. Também não conheciam a gradação nulo e anulável. Só depois, no período pós-clássico, mais precisamente, no Direito Justinianeu, em virtude da fusão do ius civile com o ius honorarium, já se pode falar - como ocorre no direito moderno - em anulação, graças aos meios de impugnação que os pretores concediam para impedir que os negócios jurídicos considerados válidos pelo ius civile produzissem efeitos. Estes meios eram: a denagatio actionis, a exceptio e a restitutio in integrum. ${ }^{283}$

${ }^{283}$ ALVES, Jose Carlos Moreira. Direito Romano. 15ª ed.. Rio de Janeiro: Gen., Forense, 2012, p. 176-177. 
De acordo com o professor Álvaro Villaça Azevedo, no direito romano o casamento continha dois elementos distintos: o objetivo, resultante da convivência do marido e da mulher, e o subjetivo representado pela afeição marital. ${ }^{284}$

Como o casamento romano não se apresentava com o caráter de indissolubilidade, quando se diz que ele é perpétuo se quer dizer que deva durar, no sentido de que os que se casam devem ter em mira não uma união passageira, mas duradora; esse é o sentido da expressão consortium ominis vitae.

O professor Álvaro Villaça Azevedo afirma que a ausência de formalidades jurídicas especiais não implicava falta de cerimônias religiosas e sociais que eram de costume entre os antigos romanos. Juridicamente, o casamento era um estado de fato que não surgia, como o atual, da troca inicial de consentimentos, mas de permanência da união com as características matrimoniais, que eram a convivência e a intenção de ser marido e mulher.

De acordo com as ponderações de Max Kaser (1968, Derecho Romano Privado, p. 256), a concepção do casamento romano é bem diversa da atual, inspirada em moldes cristãos. A celebração do matrimônio não era um negócio jurídico, nem estava ligada à observação de formas jurídicas. Seus pressupostos não estavam sujeitos a uma comprovação estatal. A ação para demandar a declaração de existência ou não do matrimônio era desconhecida. ${ }^{285}$

\subsection{Casamento no direito canônico}

Nos primeiros tempos, a Igreja tinha normas próprias sobre o casamento, proibitivas e imperativas, diferentes das leis civis, fundadas em textos evangélicos e nas epístolas de São Paulo, sem que essa união, por ela realizada, tivesse validade ante o sistema legal do Estado.

A noção geral do matrimônio canônico encontra-se na Bíblia, na ideia de que Deus, após criar o homem e a mulher, à sua imagem e semelhança, recomendou que

${ }^{284}$ AZEVEDO, Álvaro Villaça. Estatuto da Família de Fato. $3^{\text {a }}$ ed.. São Paulo: Atlas, 2011, p. 19.

${ }^{285}$ AZEVEDO, Álvaro Villaça. Estatuto da Família de Fato. $3^{\text {a }}$ ed.. São Paulo: Atlas, 2011, p. 21-22. 
fossem fecundos e que se multiplicassem, sendo tal união indissolúvel, monogâmica, formando os dois uma só carne. Portanto, o que Deus uniu o homem não separe. Essa mesma passagem é revivida pelo Apóstolo São Paulo, procurando, na mesma, explicar a união de Jesus com sua Igreja. Assim, tendo esse caráter indissolúvel, de profundo significado, o casamento se eleva à condição de sacramento.

Mesmo depois, com o aparecimento dos Imperadores Cristãos, embora com influência, a Igreja não conseguiu a possibilidade de legislar sobre o casamento e julgar sobre suas relações.

A Igreja continuou a disciplinar a conduta de seus fiéis, impondo aos cristãos suas regras, fazendo progressos maiores e mantendo seu poder, em princípio, a partir da queda do Império do Ocidente, nos reinados bárbaros, que a esse evento sucedera, embora sem legislação própria, nem jurisdição, em matéria de casamento, que conquistaria no início do século X. Inicia-se, neste século, a época clássica do Direito Canônico, principalmente em matéria de matrimônio, como verdadeiro sistema jurídico.

Entretanto, no século XVI, começou a mudar essa posição da Igreja, sendo certo que, em grande parte da Europa Ocidental, dessa época em diante, ela perdeu seu poder legislativo e seu direito de jurisdição. ${ }^{286}$

Segundo Serpa Lopes, é fora de dúvida que a ideia da inexistência do negócio jurídico tomou corpo em consequência dos trabalhos dos canonistas.

A ausência de consentimento do matrimônio foi o ponto de partida do Direito Canônico para a concepção da teoria de inexistência. No casamento celebrado sem consentimento, não há um caso de nulidade, não há nada. Todavia a nova ideia não recebeu a posição conveniente, motivo por que os canonistas a construíram sobre os fundamentos dos impedimentos e não das nulidades. ${ }^{287}$

Mas, nas fontes medievais, a qualificação de um negócio como nulo é interpretada no sentido de inexistência. Vejamos a análise de alguns cânones: convalida-se o casamento canônico nulo pelas seguintes formas: a) pela dispensa do impedimento dirimente (cânone 1.156), devendo, neste caso, ser renovado o consentimento (cânone 1.157); b) pela

${ }^{286}$ AZEVEDO, Álvaro Villaça. Dever de Coabitação, Inadimplemento. $2^{\mathrm{a}}$ ed.. São Paulo: Atlas, 2009, p. 40-45.

${ }^{287}$ LOPES, Miguel Maria de Serpa. Curso de Direito Civil. Vol. 1, $7^{\mathrm{a}}$ ed. revista e atualizada pelo Prof. José Serpa Santa Maria. Rio de Janeiro: Freitas Bastos, 1995, p. 445-446. 
manifestação pública ou particular e em segredo, feita pelo cônjuge que não o tinha manifestado, contanto que o outro persevere o consentimento (cânone 1.159); c) por nova celebração, no caso de falta de forma (cânone 1.160).

Todos estes casos de nulidade, no entanto, deveriam, na verdade, ser de inexistência do casamento, já que deve ser entabulado novo ato, não se cuidando de simples ratificação, ou, como diz o direito canônico, de convalidação simples. ${ }^{288}$

No Brasil, em matéria de casamento, vigoravam as regras religiosas do Direito Canônico. Nessa época do direito luso brasileiro, o Brasil adotava além do casamento religioso, o casamento de fato, conhecido também por casamento presumido regulado pela legislação canônica, até o advento do Concílio de Trento de 1563, e pela legislação portuguesa.

No entanto, desrespeitando essa lei natural e simples, da convivência, entendeu o legislador de criar formalismos ao casamento, concebendo-o de modo artificial, na lei. Assim, editou-se, no Brasil, o decreto $\mathrm{n}^{\circ} 181$, de 24 de janeiro de 1890, que secularizou o casamento. A partir dele, o formalismo tomou conta da legislação brasileira, em matéria de casamento, reeditando-se o sistema no Código Civil.

Portanto, deixou o Estado brasileiro não só de considerar o casamento de fato, bem como o casamento religioso, que, por si só, sem o posterior registro, era, e, é considerado concubinato puro, hoje união estável. Não tem ele existência autônoma, independente, como antes desse Decreto de 1890. Todas as formas de casamento anteriormente admitidas foram revogadas e se tornou obrigatório o casamento civil, art.108 do Decreto n 181 de $1890 .^{289}$

Ensina o professor Jorge Fujita que com a Revolução Francesa surgiu o casamento civil obrigatório, atribuindo-se ao Estado a competência exclusiva do casamento. Essa mudança teve grande repercussão na América e na Europa.

Atualmente, existem países tais como Brasil, Alemanha, Suíça e quase todos os países da América do Sul, em que somente o casamento civil é válido, sendo possível também o reconhecimento do casamento religioso com efeitos civis. Há outros em que há a

${ }^{288}$ GIULIANI, Ivani Martins Ferreira. Casamento Inexistente. Dissertação de Mestrado, Direito Civil, FDUSP, São Paulo, 1985, p.37-38.

${ }^{289}$ AZEVEDO, Álvaro Villaça. Direito de Família, Curso de Direito Civil. São Paulo: Atlas, 2013, p. 53, 58. 
liberdade de opção entre o casamento civil e o religioso, atribuindo-se a mesma validade, tal como nos Estados Unidos da América e Inglaterra. Por outro lado, em alguns países como na Espanha e na Escandinávia, prevalece o casamento religioso, estando disponível o casamento civil somente para as pessoas que tenham outra religião que não seja a oficial. $^{290}$

\subsection{Invalidade do casamento}

Para o professor Álvaro Villaça Azevedo, com relação à invalidade do negócio jurídico, o atual Código Civil deveria ter tratado da divisão tripartite da invalidade: da inexistência, da nulidade e da anulabilidade dos negócios jurídicos. Ao contrário, manteve este a posição do Código Civil de 1916, considerando os negócios inválidos em duas categorias: nulo e anuláveis. ${ }^{291}$

De acordo com José Luis de Los Mozos, a noção de inexistência do negócio jurídico surgiu na França, nos trabalhos preparatórios do Código Civil de 1804. Até a época do Código de Napoleão, não se poderia dizer que havia uma teoria a respeito da nulidade do negócio jurídico. Tal teoria surgirá da distinção do Primeiro Cônsul.

Desta distinção nasce a formulação do conceito de inexistência do negócio jurídico. $^{292}$

Como bem explica o professor Carlos Alberto Dabus Maluf ${ }^{293}$, o termo inexistência surgiu, pela primeira vez, durante a discussão do projeto do Código Civil, no Conselho de Estado, na França, motivado pelo tema da validade do casamento. O $1^{\circ}$ cônsul, Napoleão Bonaparte, apresentou uma emenda a respeito do artigo $4^{\circ}$, posteriormente, artigo 146 do Código Civil francês de 1804, propondo uma mudança do referido artigo que dizia: “Le mariage n'est pas valable, si des époux n'y ont pas donné un

${ }^{290}$ FUJITA, Jorge Shiguemitsu. Curso de Direito Civil, Direito de Família. São Paulo: Juarez de Oliveira, 2000, p. 21-22.

${ }^{291}$ AZEVEDO, Álvaro Villaça. Direito de Família. Curso de Direito Civil. São Paulo: Atlas, 2013, p. 95

${ }^{292}$ MOZOS, José Luis de Los. El Negócio Jurídico (Estudios de Derecho Civil). Revista General de Legislación y Jurisprudencia, Madrid, abr. 1960, p. 96-100.

${ }^{293}$ MALUF, Carlos Alberto Dabus. A Inexistência na Teoria das Nulidades. Tese apresentada para concurso de Professor Titular de Direito Civil da Faculdade de Direito da Universidade de São Paulo, 2001, p. 10-11. 
consentement libre...". ("O casamento não é válido se os esposos não deram um consentimento livre...").

Bonaparte, então, criticou esta redação, dizendo: "Não há matrimônio, quando não há consentimento livre".

Critério que triunfou em definitivo, sendo substituída a fórmula anterior pela seguinte: "Il n'y a pas de mariage, lorsqu'il n'y a point de consentement" ("Não há casamento, quando não há consentimento”). Assim, o artigo $4^{\circ}$, posteriormente artigo 146, deixou de figurar no capítulo das nulidades e passou então ao capítulo "Das qualidades e condições para se casar".

A doutrina entende que onde se diz "não há casamento" é o mesmo que dizer que o matrimônio não existe, portanto, inexistente.

Surge, desta forma, a figura do "néant" (inexistente), em contraposição à regra "pas de nullité sans texte" (não há nulidade sem texto), traduzindo-se, por meio da concepção de dois tipos de nulidade: as nulidades textuais e as virtuais (inexistência).

Assim, a inexistência é incluída nas nulidades "sans texte", também chamadas de nulidades racionais, tais como: identidade de sexos no matrimônio, ausência de consentimento, em oposição às nulidades legais (falta de causa, contravenção da ordem pública, etc.).

Segundo Planiol e outros autores, a origem desta distinção foi desenvolvida por Zachariae, em sua obra sobre o direito francês, sendo aceita a terminologia e o conceito de inexistência, pela escola da exegese francesa - composta entre outros por Laurent, Demolombe, Duraton, Merlin, Marcadé, Demanté, Colmet de Santerre e Mourlon.

Posto nestes termos torna-se reduzida a formulação primeira da doutrina da inexistência, perdendo deste modo a teoria da inexistência todo seu interesse, levando esta evolução à dissolução da teoria da inexistência, que resta igualada à nulidade absoluta e diferenciada da nulidade relativa ou anulabilidade. Adquirindo, assim, com outras bases, um renovado sentido da tradicional classificação binária das causas de nulidade. ${ }^{294}$

294 MALUF, Carlos Alberto Dabus. A Inexistência na Teoria das Nulidades, p. 10-13. 
No entanto, desde a sua concepção, pode o casamento apresentar vícios que tornam o ato nulo, anulável ou inexistente de pleno direito.

\title{
6.4 Configuração da inexistência do casamento
}

Na lição do professor Carlos Alberto Dabus Maluf, não se deve confundir inexistência de um ato com invalidade.

\begin{abstract}
"Inexistência é matéria a ser tratada no estudo dos atos que devem ou não ser admitidos como jurídicos. Invalidade é matéria a ser tratada no estudo daqueles requisitos cuja falta nos atos determina sua nulidade. A inexistência é matéria de política. A invalidade é matéria de técnica jurídica. A inexistência é matéria a ser considerada pelo legislador. A invalidade é matéria a ser examinada pelo juiz". ${ }^{295}$
\end{abstract}

De acordo com as noções fundamentais sobre as invalidades dos atos e negócios jurídicos, reguladas nos artigos 166 e seguintes do Código Civil de 2002, a imperfeição desses atos geralmente provém de uma das três causas seguintes: 1) falta de elemento essencial e, portanto, indispensável à sua formação, levando à inexistência dos mesmos, sem a produção de qualquer efeito; 2) prática do ato mediante infração de preceito legal obrigatório, que contenha cláusula, contrária à ordem pública e aos bons costumes, ou não se revista da forma expressamente prevista em lei que, embora reunindo os elementos essenciais, leva-o à sua nulidade insanável; 3) imperfeição da vontade, seja porque emanada por incapaz, seja porque sua manifestação encontre-se eivada de vício, como o erro, o dolo, a coação, ou, seja porque a vontade das partes, desviando-se da boa-fé e da honestidade, atue no sentido de prejudicar outrem ou de infringir preceitos legais, tornando anuláveis os mesmos. ${ }^{296}$

Concebe San Tiago Dantas que o casamento inexistente é o casamento a que faltam os requisitos essenciais para a sua existência, como a diversidade de sexo, a celebração na forma da lei e o consentimento manifestado.

\footnotetext{
${ }^{295}$ MALUF, Carlos Alberto Dabus; MALUF; Adriana Caldas do Rego Freitas Dabus. Curso de Direito de Família. São Paulo: Saraiva, 2013, p. 196.

${ }^{296}$ MONTEIRO, Washington de Barros; SILVA, Regina Beatriz Tavares da. Curso de Direito Civil, Direito de Família, 39 ed.. São Paulo: Saraiva, 2009, p. 131-132.
} 
Tal casamento inexistente rompe-se pela ação declaratória, pois nenhum vínculo jurídico se constituiu e não se pode discutir a sua validade. Há apenas a exterioridade do matrimônio e, se alguém tem dúvida sobre a sua existência ou inexistência, cabe a proposição da devida ação declaratória, para que o juiz, numa sentença de mero acertamento, declare se há casamento ou não há. Cite-se como exemplo o caso de uma pessoa que queira comprar um imóvel de um indivíduo que sabe ter contraído um casamento que se supõe inexistente; pode ter receio de fazer a aquisição, porque, se o casamento existir, será necessária a outorga uxória para a venda, e, assim, o adquirente eventual pode propor a ação declaratória, para acertar a existência ou a inexistência do matrimônio. $^{297}$

Vê-se, assim, que a inexistência não se refere a um defeito do ato, mas à falta de um elemento essencial desse ato, sem o qual ele deixa de existir, impedindo que sejam arguidas a prescrição e a decadência.

Passemos então à análise dos três requisitos do casamento inexistente, ou seja, identidade de sexos, falta de celebração e ausência total de consentimento:

Identidade de sexos: de acordo com o professor Álvaro Villaça Azevedo, todo o sistema regulador do casamento civil acolhe a diversidade de sexo como pressuposto existencial. Embora nossa sociedade assista, presentemente, ao fenômeno da convivência sob o mesmo teto, ou não, de pessoas do mesmo sexo por tempo duradouro, não se pode cogitar de casamento como regulado pelo Código Civil. Tal posicionamento decorre, da expressa menção no Código Civil de 1916, aos direitos e deveres do marido (arts. 233 a 239) e da mulher (arts. 240 a 255), sendo estes os sujeitos da relação jurídica matrimonial. $^{298}$

Ensina a professora Maria Helena Diniz que o casamento tem como pilar o pressuposto fático da diversidade de sexo dos nubentes de acordo com os arts. 1.514, 1.517, 1.565 do Código Civil de 2002 e art. 226, § 5 da Constituição Federal. Absurdo seria admitir que o matrimônio de duas mulheres ou de dois homens tivesse qualquer efeito jurídico, devendo ser invalidado por sentença judicial. Se, porventura, o magistrado

\footnotetext{
${ }^{297}$ SAN TIAGO DANTAS, Francisco Clementino. Direito de Família e das Sucessões, revista e atualizada por José Gomes Bezerra Câmara e Jair Barros. Rio de Janeiro: Forense, 1991, p. 213.

${ }^{298}$ AZEVEDO, Álvaro Villaça. Uniões Entre Pessoas do Mesmo Sexo. Revista da Faculdade De Direito. Universidade de São Paulo. Vol. 94, 1999, p. 14.
} 
deparar com caso dessa espécie, deverá, tão somente, pronunciar sua inexistência, negando a tal união o caráter matrimonial. ${ }^{299}$

No mesmo sentido ensina Washington de Barros Monteiro que em matéria de casamento também ocorrem hipóteses em que se verifica a inexistência do ato. Assim, se porventura se unissem duas pessoas do mesmo sexo, como outrora sucedeu com Nero e Sporus, ter-se-ia ato inexistente, porque para o casamento é condição vital a diversidade de sexo dos nubentes. ${ }^{300}$

Também leciona o professor Jorge Fujita, citando Washington de Barros Monteiro, que o casamento ocorrido, em Roma, entre Nero e Sporus, mediante a legislação de nosso país seria inexistente. É condição inevitável a diversidade de sexo dos contraentes, sendo que a Dinamarca, Noruega, Suécia, Holanda e Inglaterra são exceções a essa regra. $^{301}$

Ensina Pontes de Miranda ${ }^{302}$ sobre a diferença de sexo e celebração do ato que:

A união, ainda solenemente feita, entre duas pessoas do mesmo sexo, não constitui matrimônio, porque ele é, por definição, contrato do homem e da mulher, viri et mulieres coniunctio, com o fim de satisfação sexual e de procriação. Advirta-se, porém, em que a conformação viciosa ou a mutilação dos órgãos sexuais não torna impossível a existência do casamento (E.PACIFIC-MAZZONI, Instituzioni di Diritto Civile italiano, VII, 12), se o sexo pode ser reconhecido e se distingue do sexo do outro cônjuge. A ignorância de defeito físico irremediável ou de moléstia grave e transmissível entra na classe dos impedimentos dirimentes relativos: concerne, portanto, à validade, e não à existência do casamento. Se, no caso de conformação viciosa, predomina o sexo igual ao do outro cônjuge, está expressa a figura da igualdade sexual, e, ipso facto, inexistente o casamento. Dar-se-á o mesmo em caso de indistinção sexual, quia coniuge non habet sexum (ZACHARIE, De Droit Civil Français, I, 171; aliás, era bem de esperar que ao formulador da teoria dos atos inexistentes não escapasse o caso do "cônjuge sem sexo").

Ilustra, em seguida, com interessante caso da jurisprudência pátria, o julgado do Tribunal Civil e Criminal do Distrito Federal (21 de outubro de 1895, OD., 68, 540), que:

\footnotetext{
${ }^{299}$ DINIZ, Maria Helena. Curso de Direito Civil Brasileiro. Direito de Família, Vol. 525 ed. São Paulo: Saraiva, 2010, p. 54.

${ }^{300}$ MONTEIRO, Washington de Barros; SILVA, Regina Beatriz Tavares da. Curso de Direito Civil. Direito de Família. 39 edição. São Paulo: Saraiva, 2009, p. 132.

${ }^{301}$ FUJITA, Jorge Shiguemitsu. Curso de Direito Civil. Direito de Família. São Paulo: Juarez de Oliveira, 2000 , p. 144.

${ }^{302}$ MIRANDA, Francisco Cavalcanti Pontes de. Tratado de Direito Privado: Parte Especial. Tomo VII, Direito de Personalidade, Direito de Família. Direito matrimonial (Existência e validade do casamento), atualizado por Rosa Maria de Andrade Nery, RT: São Paulo: 2012, p. 462-463.
} 
"Na vigência do Decreto n. 181, de 24 de janeiro de 1890, considerou inexistente o casamento contraído entre duas pessoas do mesmo sexo, julgado em que, acertadamente, se houve por imprescindível a ação contra tal casamento. A terminologia, aliás, no acórdão, não é rigorosa. Também nele se comete grave erro de doutrina, qual o de se reputar matrimonium non existens o casamento contraído entre pessoa de sexo firme e outra de estado intersexual, hermafrodita, quer andrógino, quer ginandro. Se o sexo preponderante é diferente do sexo do cônjuge normal, ou há dúvida sobre a preponderância, tal casamento apenas é anulável por defeito físico irremediável. $\mathrm{O}$ acórdão não atendeu à distinção, e daí o perigo na sua consulta".

Leciona o professor Álvaro Villaça Azevedo que importante decisão do Tribunal de Justiça do Estado de Minas Gerais, Ap. 56.899, por sua $1^{\text {a }}$ Câmara, unanimemente, em 16 de novembro de 1982, sendo relator o desembargador Paulo Tinoco (RT 572/189), deve ser lembrada: "é ato inexistente o casamento de duas pessoas do sexo feminino" e não nulo. Admite esse decisório que deve existir a declaração de inexistência do casamento, pois existiu o ato, não o casamento, daí porque "o ato é nulo"; considerado ato " $a$ realização, formalidade e registro feito nos livros cartorários". A seu turno, corroborou o desembargador Oliveira Leite, em seu voto, que a sentença contém impropriedade, principalmente porque declarou nulo casamento inexistente. ${ }^{303}$

Aduz o professor Álvaro Villaça Azevedo ser correta a posição acolhida nesse acórdão, porque o pressuposto da diversidade de sexo no casamento não é defeito sanável ou insanável desse contrato solene matrimonial, mas requisito essencial de sua própria existência.

Portanto, pode o juiz declarar a inexistência do casamento, independentemente de ação tendente a esse reconhecimento. Assim julgou a $6^{\mathrm{a}}$ Câmara do Tribunal de Justiça do Estado de São Paulo, sendo relator o desembargador Roque Komatsu (RT 615/47) em 21 de agosto de 1986. Assenta-se, nessa decisão, que “inexistente é o casamento levado a efeito por pessoas do mesmo sexo, tendo sido utilizado falso registro de nascimento para a consumação do ato". 304

Assim, desse modo, o ato inexistente nem chega a ingressar no mundo jurídico, porém, embora ele exista no plano fático, às vezes se torna necessário o ajuizamento de

\footnotetext{
${ }^{303}$ AZEVEDO, Álvaro Villaça. Uniões Entre Pessoas do Mesmo Sexo. Revista da Faculdade De Direito. Universidade de São Paulo. Vol. 94, 1999, p. 15.

${ }^{304}$ AZEVEDO, Álvaro Villaça. Uniões Entre Pessoas do Mesmo Sexo. Revista da Faculdade De Direito. Universidade de São Paulo. Vol. 94, 1999, p. 15.
} 
ação para desconstituir seus efeitos ou para impedir a produção destes, em decorrência dessa situação de fato, de mera aparência. ${ }^{305}$

Falta de celebração: ensina o professor Washington de Barros Monteiro que terse-á por ato inexistente quando não há celebração com observância do disposto nos artigos 1.535 e 1.536 do Código Civil de 2002; assim, se o ato se realiza, não perante o juiz, mas perante um particular qualquer (prefeito, delegado de polícia), que se arroga aquela qualidade, o casamento é inexistente. Considera-se que não houve casamento. Somente a celebração na forma da lei permite distinguir o casamento da mera relação de fato. ${ }^{306}$

No entanto, toda afirmação peremptória em Direito pode ser duvidosa, pois o casamento realizado por quem não é juiz de casamentos poderá configurar casamento putativo, dependendo das circunstâncias. Por outro lado, se o celebrante é juiz de casamentos incompetente ratione loci, por ser de outra circunscrição, a hipótese, no Código de 2002, é de anulabilidade, segundo o art. 1.550, VI, definindo o legislador como vício sanável. ${ }^{307}$

Caio Mário reporta-se à sua vida profissional, onde teve em suas mãos escritura pública de união matrimonial e instrumento particular de casamento temporário. Tais são, por óbvio, exemplos de casamento inexistente. Provado o fato, há que se declarar a inexistência. Porém, aqui, a boa-fé dos cônjuges, ou de um deles, é de ser considerada, para se reconhecerem efeitos ao ato, isto é, casamento putativo, o qual é aprovado por boa parte da doutrina. ${ }^{308}$

Ausência total de consentimento: se não houve consentimento do contraente, o ato nupcial é inexistente. $\mathrm{O}$ casamento repousa indeclinavelmente no mútuo consenso dos interessados. Se um destes não chega a se manifestar de modo específico, conservando-se indiferente à pergunta fundamento formulada pelo juiz, não há consentimento e o casamento inexiste.

\footnotetext{
305 AZEVEDO, Álvaro Villaça. Uniões entre Pessoas do Mesmo Sexo. Revista da Faculdade de Direito. Vol. 94, 1999, p. 14-15.

${ }^{306}$ MONTEIRO, Washington de Barros; SILVA, Regina Beatriz Tavares da. Curso de Direito Civil, Direito de Família. 39 ed.. São Paulo: Saraiva, 2009, p. 132-133

${ }^{307}$ VENOSA, Sílvio de Salvo. Direito Civil, Direito de Família. Vol. VI, 13 ed.. São Paulo: Atlas, 2013, p. 106.

${ }^{308}$ PEREIRA, Caio Mário da Silva. Instituições de Direito Civil, Direito de Família. Vol. V, 20 ed., revista e atualizada por Tânia da Silva Pereira. Rio de Janeiro: Gen e Forense, 2012, p. 143-144.
} 
Para que tenhamos como inexistente o matrimônio, mister que tratemos de omissão na manifestação de vontade e não simples declaração defeituosa. Vontade viciada situa-se em sede de anulabilidade do ato. Ausência de vontade caracteriza sua inexistência. O mesmo ocorre se a cerimônia se conclui com a negativa do nubente. O sim é absolutamente essencial para a conclusão do ato. ${ }^{309}$

As três hipóteses mencionadas (identidade de sexos, ausência de consentimento e falta de celebração) constituem os casos geralmente apontados pelos tratadistas para indicar o casamento inexistente, que não pode, de modo algum, sanar-se pela ratificação ou pela prescrição, porque não se pode reconhecer, confirmar ou dar vida ao que não existe. Em princípio, não há necessidade de ação para se obter a decretação da inexistência do casamento. Todavia, se o fato alegado depende de provas, como, por exemplo, a ausência de consentimento de um dos nubentes, ou deixar rastro material, tornar-se-á então imprescindível ação judicial que assim o declare. ${ }^{310}$

Pondera, a seu turno, Caio Mário da Silva Pereira que não se trata de declaração de vontade defeituosa, eivada de erro ou coação, nem de pessoa incapaz de consentir permanentemente ou eventualmente. Trata-se, neste caso, da ausência absoluta de consentimento, como no exemplo de cerimônia que se conclua, apesar da declaração negativa formal do nubente (é certo que no Direito francês, esta causa de inexistência desapareceu, com a Lei de 19 de fevereiro de 1933, que sob este fundamento, instituiu caso específico de nulidade absoluta).

A inexistência apresenta a vantagem adicional de impedir que se arguam a prescrição e a decadência do defeito. ${ }^{311}$

Quanto à relação entre casamento inexistente e casamento putativo, Yussef Cahali, adota a posição de Messineo, para quem parece razoável que se possa considerar a ocorrência de matrimônio putativo, não apenas nos casos de nulidade de matrimônio, mas também naqueles em que se considera inexistente o casamento (falta ou declaração de vontade de um só dos esposos e falta de celebração); portanto, sendo o matrimônio

\footnotetext{
${ }^{309}$ VENOSA, Sílvio de Salvo. Direito Civil, Direito de Família. Vol. VI, 13 ed.. São Paulo: Atlas, 2013, p. 107.

${ }^{310}$ MONTEIRO, Washington de Barros; SILVA, Regina Beatriz Tavares, da. Curso de Direito Civil: direito de família. V. 2, 39 ed.. São Paulo: Saraiva, 2009, p. 132-133.

${ }^{311}$ PEREIRA, Caio Mário da Silva. Instituições de Direito Civil. Vol. V, Direito de Família, 20 ed. revista e atualizada por Tânia da Silva Pereira. Rio de Janeiro: Gen, Forense, 2012, p. 144.
} 
putativo fundado no estado de boa-fé dos cônjuges, a distinção entre nulidade e inexistência (mesmo para os que a admitem) não modifica a essência de função de boa-fé.

Pelo menos para o casamento inexistente que logrou registro, é razoável esse entendimento porque nossa lei civil, diferentemente de alguns países, tal como Portugal, não veda expressamente a putatividade do casamento inexistente, embora haja doutrina em sentido contrário.

Entre nós, no sentido de que o casamento inexistente não comporta ser putativo, pronunciam-se Washington de Barros Monteiro, Sílvio Rodrigues, Moreira Guimarães, João Arruda, Pontes de Miranda, Clóvis Bevilaqua, Espínola e Orlando Gomes.

A não aplicação da teoria, em se tratando de casamento inexistente, é no geral fundada em que o nada, uma coisa que nunca existiu, não pode criar ou produzir efeito algum. Se em tais casos, os efeitos dependessem, unicamente, da boa-fé dos pretensos cônjuges, seríamos conduzidos à conclusão, manifestamente contrária a todo sistema jurídico, de que basta o concubinato, acompanhado da crença de se encontrarem unidos pelo matrimônio, para que sejam produzidos os efeitos de um matrimônio válido. Esse entendimento, porém, foi sendo paulatinamente contrariado com a ponderação de que, não é do nada que se buscam extrair os efeitos da putatividade, mas da boa-fé dos esposos, cuja situação pode ser digna de proteção tanto no caso de matrimônio inexistente como no caso de matrimônio nulo. ${ }^{312}$

Quanto ao casamento religioso ou canônico, preleciona o professor Carlos Alberto Dabus Maluf, que, em interessante artigo de doutrina, Mário Moacyr Porto diz que se poderia incluir no rol dos atos inexistentes o casamento religioso ou canônico, entre nós equiparado à união estável. O casamento religioso não é nulo, pois lei alguma proíbe a sua celebração. É, ao que parece, inexistente, pois o Estado o ignora e lhe nega efeitos jurídicos, salvo os efeitos atribuídos à união estável. ${ }^{313}$

Em sentido contrário, entendeu o Tribunal de Justiça do Estado da Guanabara, em 1971, sendo relator o Juiz Francisco Pereira de Bulhões Carvalho (RT 427/238, maio 1971), que:

312 CAHALI, Yussef Said. O Casamento Putativo. 2 ed.. São Paulo: RT, 1979, p 52-54.

${ }^{313}$ MALUF, Carlos Alberto Dabus. A Inexistência na Teoria das Nulidades, p. 154-155. 
A celebração religiosa do casamento, longe de ser um ato inexistente, tem sua existência prevista expressamente pela Constituição Federal (art. 163 da Constituição de 1946 e art. $175, \S \S 3^{\circ}$ e $4^{\circ}$, da atual Constituição), que apenas subordina seus efeitos civis à sua inscrição no registro. A retroatividade dos efeitos do registro demonstra que o casamento, desde a data de sua celebração, é ato existente e válido, cuja eficácia fica pendente de futuro registro. Descabe ação civil para declarar sua nulidade ou sua anulação. Se o ato não tem eficácia civil, sua anulação somente pode ser feita perante o tribunal religioso competente. ${ }^{314}$

Em julgamento realizado em 11/09/2008, a Oitava Câmara Cível do Tribunal de Justiça do Rio Grande do Sul, negou, por maioria, habilitação de casamento entre dois homens:

\begin{abstract}
Apelação Cível $\mathbf{N}^{\mathbf{0}}$ 70025659723, TJRS, $8^{\mathrm{a}}$ Câmara Cível, Relator Claudir Fedelis Faccenda. Data julgamento: 11/09/2008

Ementa: APELAÇÃO CÍVEL. PEDIDO DE HABILITAÇÃO DE CASAMENTO. PESSOAS DO MESMO SEXO. AUSÊNCIA DE SUPORTE LEGAL. O sistema legal brasileiro, em particular o Código Civil, não prevê e nem autoriza interpretação no sentido da possibilidade do casamento entre pessoas do mesmo sexo. Ao contrário, os artigos $1.514,1.517$ e 1.565, do Código Civil, exigem que o casamento se realize entre homem e mulher. Assim, o casamento entre pessoas do mesmo sexo não encontra amparo na legislação vigente no nosso país. PRELIMINARES REJEITADAS, À UNANIMIDADE. NO MÉRITO, APELO NÃO PROVIDO, POR MAIORIA. ${ }^{315}$
\end{abstract}

O Tribunal do Rio Grande do Sul, por dois votos a um, negou o pedido para que dois homens fossem considerados habilitados ao casamento civil. O Colegiado apreciou apelação interposta contra decisão de $1^{\circ}$ Grau que indeferiu a autorização para o Registro Civil. O recurso foi relatado pelo Desembargador Claudir Fidelis Faccenda, que concluiu pela impossibilidade jurídica do pedido: “O problema está em que a Constituição Federal expressamente só aceita união estável entre heterossexuais, ou seja, não é omissa".

O Desembargador José Ataídes Siqueira Trindade acompanhou o voto do relator.

O Desembargador Rui Portanova, em um inflamado voto que durou cerca de uma hora, afirmou ser possível a concessão da pretensão; destacamos algumas ponderações:

Questão muito semelhante foi enfrentada, recentemente, pelo STJ, no julgamento do REsp 820475-RJ, em que se discutia a possibilidade de reconhecimento da união estável entre dois homens.

\footnotetext{
${ }^{314}$ RT-427/238. Acesso em 10 out. 2013.
315 Apelação $\quad$ Cível $\quad \mathrm{N}^{\circ} \quad 70025659723 . \quad$ Disponível em: http://www.tjrs.jus.br/busca/search?q=\&entsp=a_politica-site \&wc=2008wc mc=1\&oe=UTF-\&ie . Acesso em 05 jul. 2015.


O juízo singular entendeu não ser possível, por ausência de disposição legal expressa, e extinguiu o feito por "impossibilidade jurídica do pedido". A preliminar, no entanto, foi superada pelo STJ, que declarou, por maioria, não ser o caso de impossibilidade jurídica. Entendeu o Tribunal que a impossibilidade jurídica do pedido estará configurada somente naquelas situações de expressa vedação legal.

E agora o detalhe relevante: tanto no caso do REsp 820475-RJ, quanto no caso do presente apelo, não se vislumbra qualquer vedação legal.

Pelo contrário, considerando que o Direito é um sistema ordenado e harmônico de normas, é fundamental reconhecer que os dispositivos da Constituição e da legislação ordinária que tratam do casamento precisam ser compatibilizados com outros dispositivos constitucionais, como por exemplo: preâmbulo; art. $1^{\circ}$, II, III; art. $3^{\circ}$; art. $4^{\circ}$, II; art. $5^{\circ}$, caput, I, II, III, IV, X, XXXV, $\S \S 2^{\circ}$ e $3^{\circ}$; art. 19, III; art. 193; art. 226, caput e $\S 4^{\circ}$.

E quero, nesse ponto, desde logo, acrescentar: o casamento entre pessoas do mesmo sexo, por igual, não é ato jurídico proibido expressamente por lei. Não há vedação legal expressa.

Naquilo que existe sobre a matéria, penso que, se o intuito da lei fosse afastar a possibilidade do casamento entre pessoas do mesmo sexo, ao invés de usar a expressão "homem e mulher" usaria "homem com mulher". Logo é lícito dizer que são os intérpretes e as interpretações que levam à impossibilidade de se admitir o casamento entre pessoas do mesmo sexo.

No Brasil, vige o princípio da interpretação conforme a Constituição, o que implica dizer que os textos legais não são autossuficientes, mas que dependem de uma leitura dos princípios constitucionais, a fim de lhes dar suporte valorativo, integrando a regra jurídica ao ordenamento, como um todo harmônico.

Mas o que está faltando para que os autores casem? Falta o exercício de um Poder do Estado, constitucionalmente incumbido de efetivar esse direito.

\subsection{O reconhecimento pelo STJ do casamento homoafetivo}

Após a decisão histórica do Supremo Tribunal Federal sobre o reconhecimento da união homoafetiva como entidade familiar, inúmeros pedidos de conversão de união homoafetiva em casamento homoafetivo e de habilitação para o casamento homoafetivo bateram às portas do Poder Judiciário. 
As decisões a respeito do tema não eram pacíficas e dependiam do entendimento de cada julgador em cada Estado do país.

Selecionamos e resumimos algumas primeiras decisões dos Estados de São Paulo, Distrito Federal, Santa Catarina, Recife e Rio de Janeiro que acolheram o pedido de conversão:

- São Paulo - Jacareí - Pedido de conversão de união estável homoafetiva em casamento. (TJSP, Protocolo n ${ }^{\circ}$ 1209/2011, Juiz de Direito Fernando Henrique Pinto, j. 27/06/2011). Trata-se de pedido realizado por dois homens, que declararam, por meio de escritura pública lavrada em 17/05/2011, que viviam em união estável há oito anos. Duas testemunhas declararam que os requerentes mantém convivência pública, contínua e duradoura e estabelecida com o objetivo de constituição de família. Os fundamentos foram o art. 226, $\S 3^{\circ}$, parte final, da Constituição Federal, e o art. 1.726 do Código Civil e normas da Corregedoria Geral da Justiça de São Paulo que disciplinam o procedimento de conversão da união estável em casamento. Sobre a possibilidade de casamento civil entre pessoas do mesmo sexo foram citados os princípios da igualdade, dignidade da pessoa humana e os objetivos fundamentais da República de construção de uma sociedade livre, justa e solidária, bem como promover o bem de todos, sem preconceitos de origem, raça, sexo, cor, idade e quaisquer outras formas de discriminação. Também determina a Constituição Federal que todos são iguais perante a lei, sem distinção de qualquer natureza e que a família, base da sociedade tem especial proteção do Estado. A Constituição Federal também declara que "para efeito da proteção do Estado, é reconhecida a união estável (...) como entidade familiar, devendo a lei facilitar sua conversão em casamento". Em harmonia com o princípio da igualdade, nossa Lei Maior enfatiza que "os direitos e deveres referentes à sociedade conjugal são exercidos igualmente pelo homem e pela mulher" (art. 226, $\S 5^{\circ}$ ). Aqui cabe abrir parênteses para alertar que tal dispositivo não necessariamente declara que casamento existe apenas entre homem e mulher, até porque "sociedade conjugal" não é "casamento", sendo certo que a primeira 
sempre pôde ser dissolvida pela "separação" (de fato, judicial e mais recentemente também extrajudicial), e o segundo somente é dissolvido pelo divórcio. O douto magistrado também tece comentários sobre a laicidade do Estado, sobre a equivocada origem psíquica dos homossexuais, sobre a ausência de respaldo jurídico a uma realidade social e sobre o receio infundado que muitos têm sobre o potencial envolvimento de crianças ou adolescentes na entidade familiar formada por pessoas do mesmo sexo. Observou também a decisão do Supremo Tribunal Federal que reconheceu a união entre pessoas do mesmo sexo como entidade familiar. Finalmente anota que no último dia 17 de junho de 2011, o Conselho de Direitos Humanos da ONU aprovou uma resolução histórica destinada a promover a igualdade dos seres humanos, sem distinção de orientação sexual. Assim, foi homologada a disposição de vontades declarada pelos requerentes para converter em casamento, pelo regime escolhido da comunhão parcial de bens, a união estável dos mesmos. $^{316}$

- Brasília, Distrito Federal - Pedido de conversão de união estável homoafetiva em casamento. (DF, Proc. No 101695-7/2011, Juíza de Direito Sub. Junia de Souza Antunes, j. 28/06/2011). As requerentes declaram-se solteiras e que desejam se casar sob o regime da comunhão parcial de bens. Aduzem que vivem em união homoafetiva desde 20 de fevereiro de 2000, de maneira pública, contínua e duradora, com intuito de constituir família e que lavraram escritura pública declaratória de reconhecimento de união estável e firmaram testamentos tendo uma e outra como herdeiras. Foram tomados os depoimentos de duas testemunhas. Com fundamento em recente decisão do STF reconhecendo as uniões homoafetivas como entidades familiares equiparadas às uniões estáveis, estão pleiteando reconhecimento da união estável com a consequente conversão em casamento. Naquele julgamento, o eminente Ministro Ayres Britto assim concluiu:

"Pelo que dou ao artigo 1.723 do CC interpretação conforme a Constituição para dele excluir qualquer significado que impeça o

316 Sentença Comarca de Jacareí/SP. Disponível em:
http://www.direitohomoafetivo.com.br/anexos/juris/1079.pdf. Acesso em 12 jul. 2015. 
reconhecimento da união contínua pública e duradoura entre pessoas do mesmo sexo, como entidade familiar, entendida esta como sinônimo perfeito de família. Reconhecimento que é de ser feito segundo as mesmas regras e com as mesmas consequências da união estável heteroafetiva".

Foram citados o art. $4^{\circ}$, LICC, $\S 3^{\circ}$ do art. $226, \mathrm{CF}$, combinado com art.

1.726 do CC. O Ministério Público deu parecer favorável. Em sua sentença a MM Juíza consignou:

Afirmar que a decisão é dotada de eficácia erga omnes e que tem efeito vinculante significa dizer que além de ser uma decisão geral, que atinge a todos, também é uma decisão que vincula a todos, em geral, inclusive os integrantes do Poder Judiciário e da Administração Pública. Desse modo, não há para o administrador e nem para o magistrado espaço para a discricionariedade e nem para o livre convencimento. Ao conceder força vinculante e erga omnes, o nosso legislador intenciona evitar a incidência de decisões discrepantes nas matérias decididas pelo Supremo Tribunal Federal, em sede de controle de constitucionalidade abstrato, e, assim, afastar a insegurança jurídica que é prejudicial à paz social. É através dessa eficácia contra todos e do efeito vinculante que as decisões de nosso Tribunal Superior se tornam obrigatórias e devem ser respeitadas. $[.$.

Com a decisão prolatada o Supremo Tribunal Federal aboliu qualquer interpretação que pretendesse diferenciar as relações homoafetivas das heteroafetivas, ressaltando que o instituto da família abrange e protege ambas e, em consequência, concluiu que é possível a união estável homoafetiva nos mesmo moldes em que ocorre a união estável heteroafetiva. É essencial evidenciar que, em que pese o voto do Senhor Ministro Ricardo Lewandowski, que aplicou, pelo processo de integração analógico, às mesmas as "prescrições legais relativas às uniões estáveis heterossexuais, excluídas aquelas que exijam a diversidade de sexo para o seu exercício, até que sobrevenham disposições normativas específicas que regulem tais relações", a conclusão da Corte Suprema não encampou esse entendimento, ampliando assim o conceito de união estável, para nele incluir toda e qualquer relação duradoura, pública e contínua, com intuito de constituir família, independente do sexo ou opção sexual do casal.

\section{$[\ldots]$}

A decisão vinculante do Supremo Tribunal Federal não deixa qualquer margem de dúvidas a esse respeito, porque consta de seu dispositivo que o "Reconhecimento DEVE ser feito segundo as mesmas regras e mesmas consequências da união estável heteroafetiva". Cediço que uma das consequências da união estável é a sua conversão em casamento, conversão essa que deve ser facilitada, e é exatamente isso que pretendem as requerentes através da presente ação.

\section{$[\ldots]$}

Assim, na medida em que o matrimônio assegura direitos que não são conferidos àqueles que vivem em união estável, efeitos estes, inclusive, 
mais benéficos, resta evidenciado o interesse jurídico do pleito das requerentes.

\section{$[\ldots]$}

Um dos interesses do Estado em facilitar a conversão da união estável em casamento é trazer segurança jurídica à família e à sociedade. Ora, não se alcança essa segurança jurídica se excluir qualquer entidade familiar do instituto do casamento.

Ao final a união estável homoafetiva entre as requeridas foi declarada existente e houve a conversão em casamento sob o regime da comunhão parcial de bens. ${ }^{317}$

- Santa Catarina - Itajaí - Conversão de união estável em casamento. (SC, Autos no 033.11.010261-7, Juiz de Direito Roberto Ramos Alvim, j. 15/07/2011). O Ministério Público opinou pela procedência do pedido. Com fundamento no artigo 1.726 do Código Civil as autoras pretendem a conversão da união estável que mantém em casamento. Trouxeram aos autos uma certidão de casamento religioso realizado na Sociedade Espiritualista de Umbanda Nosso Senhor do Bonfim, e também um Contrato de Convivência Mútua - União Estável Homoafetiva, cujo início se deu em 01/01/2010.

Para a procedência do presente pedido, haveria que estar dirimida a questão da possibilidade do reconhecimento da existência de união estável ou sociedade de fato entre as autoras. Entretanto, isso restou decidido pelo Supremo Tribunal Federal que em histórico julgamento, unânime, datado de 05 de maio de 2011, da lavra do Excelentíssimo Ministro Ayres Brito, DD. Relator, finalmente reconheceu a existência da união entre pessoas - casais- do mesmo sexo, reescrevendo o artigo 1.723 do Código Civil, que impedia que tais uniões fossem reconhecidas como entidade familiar, estendendo seus efeitos vinculantes a todos os demais órgãos do Poder Judiciário, nos exatos termos do artigo 102, $\S 2^{\circ}$ da Constituição Federal.

Tal decisão, repito, histórica, veio ao encontro do princípio Constitucional da igualdade de todos os cidadãos e por decorrência lógica de sua dignidade como seres humanos, abominando quaisquer formas de discriminação, até porque insculpido no artigo $5^{\circ}$, inciso $1^{\circ}$ da Carta Magna, encontramos a determinação da igualdade de todos perante a lei homens e mulheres - sem quaisquer distinções.

E isso se aplica igualmente às entidades familiares, as quais, por serem a base da sociedade, desfrutam de especial proteção do Estado (art. 226, caput da CF). Assim, em face do reconhecimento da união estável entre pessoas do mesmo sexo, como entidade familiar, podem estas serem

317 Sentença do Distrito Federal-Brasília. Disponível em: http://www.direitohomoafetivo.com.br/anexos/juris/1082.pdf. Acesso em 12 jul. 2015. 
convertidas para casamento conforme previsão contida no $\S 3^{\circ}$ do mesmo artigo supra mencionado. ${ }^{318}$

Finalmente, o pedido das autoras foi julgado procedente e em consequência foi decretada a conversão da união estável em casamento e a adoção do regime da comunhão parcial de bens.

- Pernambuco - Recife - Pedido de conversão de união estável homoafetiva em casamento. (PE, $1^{\text {a }}$ Vara de Família e Registro Civil, Juiz de Direito Clicério Bezerra e Silva, j. 02/08/2011). Os autores mantêm uma união estável desde 10 de outubro de 1988, conforme sentença homologatória de escritura de convivência afetiva e contraíram casamento em 10/12/2010, na Conservatória do Registro Civil de Lisboa, Portugal. Este ato não pode ser transcrito no Brasil em razão de não ter sido legalizado por autoridade consular, tendo em vista que o casamento entre pessoas do mesmo sexo não é previsto no ordenamento jurídico. O pedido foi instruído com declaração de duas testemunhas, que atestaram que os requerentes não tem qualquer impedimento que obste a conversão de união estável em casamento. O Ministério Público deu parecer favorável.

O objetivo deste feito administrativo é a conversão em casamento da união estável, já declarada como entidade familiar, por força da sentença que reconheceu como legítima a união mantida pelos requerentes há mais de 12(doze) anos, de forma pública, contínua e duradoura, com o escopo de constituição de família.

\section{$[\ldots]$}

Porém, não me parece razoável, à luz da hermenêutica, das considerações históricas, ideológicas, econômicas, políticas e sociais do Estado Brasileiro, que aos homoafetivos seja resguardado, tão somente, o direito de ver reconhecidas suas uniões, que aprioristicamente, são estáveis, nos requisitos e formas da lei.

Aqui, em prol de uma "falsa segurança jurídica", estar-se-ia criando um problema tão danoso quanto ao anterior, pois mitigações seriíssimas aos direitos fundamentais dos homoafetivos (igualdade, liberdade, intimidade, não discriminação, etc.) continuariam a ser perpetradas, confinando-os ao constante estado de ameaça de lesão, pelo próprio Estado democrático de Direito, por mais contra-senso que o seja!

\footnotetext{
318 Sentença Comarca de Itajaí/SC. Disponível em: http://www.direitohomoafetivo.com.br/anexos/juris/1172_bce652be95ec4ac5c7766dea7288eceb.pc Acesso em 12 jul. 2015.
} 
Isto porque, o próprio Estado já previu, no bojo de seu sistema, a facilitação da progressão do vínculo precário de afeto (uniões estáveis) ao vínculo institucionalizado (casamento), em prol da verdadeira e mais abrangente segurança jurídica dos nubentes, no atendimento aos seus direitos patrimoniais, previdenciários, sucessórios, de procriação, adoção, etc.

Nessa mesma toada de intelecção, o artigo 1.723 e 1.726 do Código Civil devem se interpretados de forma arqueável, a fim de trazer maior robustez à pretensão dos homoafetivos em ver suas vidas e relações familiares albergadas e reguladas pelas mesmas normas aplicáveis aos seus pares sociais, sem distinção ou discriminação de qualquer espécie.

\section{$[\ldots]$}

Anote-se que a aludida decisão do Supremo Tribunal Federal se reveste de um duplo efeito.

Primeiro, para reconhecer a existência de mais um tipo de entidade familiar: o da união entre pessoas do mesmo sexo.

Segundo, para estender os mesmos direitos e deveres dos companheiros nas uniões estáveis àqueles que optam pela relação homoafetiva incluindo, aqui, o direito à conversão da união estável entre pessoas do mesmo sexo em casamento.

Nos últimos 2 (dois) meses que se sucederam, espocam pelo país, como efeito irradiante da decisão em comento, uma série de pedidos de conversão de uniões estáveis em casamento de pessoas do mesmo sexo, e, mais recentemente, pedidos diretos de habilitação ao casamento.

\section{$[\ldots]$}

Em resumo e valendo-me de uma forma dedutiva de raciocínio, sedimentada no silogismo, arremato essa temática com a seguinte argumentação lógica:

O Supremo Tribunal Federal, em decisão com eficácia erga omnes e efeito vinculante, instituiu uma nova entidade familiar - a união homoafetiva - equiparando-a à união estável.

Ora, a Constituição Federal determina que seja facilitada a conversão de união estável em casamento.

Logo, a união homoafetiva também deve ter facilitada a sua conversão em casamento.

É, pois, o que faço nesta decisão. ${ }^{319}$

- Rio de Janeiro - Proc. No 72290/98, Vara de Registros Públicos, Juiz de Direito Fernando Cesar Ferreira Viana, j. 15/08/2011. Os conviventes declaram ter iniciado união estável a partir de 11 de setembro de 2010,

319 Sentença da Comarca de Recife. Disponível em:


conforme declaração de pacto de convivência homoafetiva firmada por ambos e por diversas testemunhas. Afirmam não existirem impedimentos para receberem-se em matrimônio e optam pelo regime da comunhão parcial de bens.

\section{$[\ldots]$}

A nova relação jurídica criada não pelo legislador, mas por interpretação Constitucional do STF, trouxe como principal consequência o questionamento sobre a possibilidade de se admitir no Direito Brasileiro o "casamento" entre pessoas do mesmo sexo.

\section{$[\ldots]$}

O Código Civil institui duas formas para os cônjuges receberem o matrimônio, uma formal por meio de processo de habilitação prevista nos artigos 1.511 e ss. CC. e outra de modo mais simplificado por meio da conversão de reconhecida anterior união estável vivida entre os companheiros (art. 1.723 CC).

No procedimento de habilitação o casamento se realiza segundo disposição do art. 1.514 do CC, no momento em que o homem e a mulher manifestam, perante o juiz, a sua vontade de estabelecer vinculo conjugal, e o juiz os declara casados.

Tal dispositivo com certeza não foi alcançado pelo julgado Excelso, pois como muito bem colocado no eloquente parecer Ministerial, houve vertentes conflitantes em relação à fundamentação feita pelos diversos Ministros que participaram do julgamento.

Neste aspecto, reproduzo o item 13, do Parecer Ministerial de fls. 41:

13- Há os que entendem que a hipótese precisa de regulamentação legislativa pelo Congresso Nacional, tal como se transcreve: "Por sua vez, os Ministros Ricardo Lewandowisk, Gilmar Mendes e Cezar Peluso, Presidente, embora reputando as pretensões procedentes, assentavam a existência de lacuna normativa sobre a questão. O primeiro enfatizou que a relação homoafetiva não configuraria união estável - que impõem gêneros diferentes- mas forma distinta de entidade familiar, não prevista no rol exemplificativo do art. 226 da CF. Assim, considerou cabível o mecanismo da integração analógica para que sejam aplicadas as mesmas normas das uniões estáveis heterossexuais, excluídas aquelas que exijam a diversidade de sexo para o seu exercício, até que o Congresso Nacional lhe dê tratamento legislativo."

Fica, portanto, evidenciado que embora tenhamos diversidade de procedimentos convergindo a um mesmo fim - o matrimônio - o julgado apenas referiu-se às relações previstas no artigo 1.723 do $\mathrm{CC}$, modificando, por conseguinte, os direitos dela derivados.

Com efeito, todos aqueles que vivenciaram união estável na forma prevista no artigo 1.723 do $\mathrm{CC}$, indistintamente se heterossexual ou homossexual, terão os mesmos direitos e deveres advindos desta relação 
jurídica, inclusive o de receberem matrimônio por meio do procedimento de conversão.

Por fim, com fulcro no art. 226, $\S 3^{\circ}$ da Constituição Federal e em vista do parecer favorável do Ministério Público, o pedido de conversão da união estável em casamento foi homologado. ${ }^{320}$

Porém, no Estado do Rio Grande do Sul duas mulheres alegando que se relacionavam de maneira estável há três anos, requereram habilitação para o casamento junto a dois Cartórios de Registros Civis de Porto Alegre, pedido que lhes foi negado pelos respectivos titulares.

Em seguida, em 25/03/2009, ajuizaram pleito de habilitação para o casamento perante a Vara de Registros Públicos e de Ações Especiais da Fazenda Pública da Comarca de Porto Alegre/RS, afirmando inexistir óbice no ordenamento jurídico a que pessoas do mesmo sexo se casem.

A sentença julgou improcedente o pedido de habilitação, por entender que o casamento, tal como disciplinado pelo Código Civil de 2002, somente é possível entre homem e mulher.

Em grau de apelação, a sentença foi mantida por acórdão assim ementado:

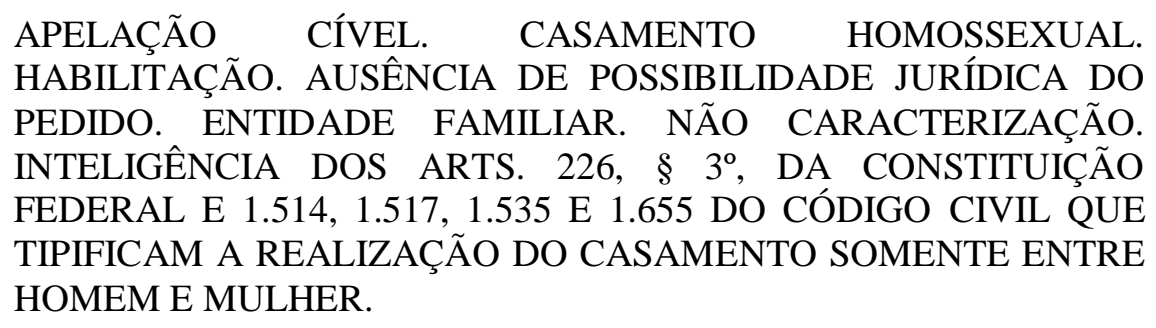

Ao contrário da legislação de alguns países, como é o caso, por exemplo da Bélgica, Holanda e da Espanha, e atualmente o estado de Massachussetts, nos USA, que preveem o casamento homossexual, o direito brasileiro não prevê o casamento entre pessoas do mesmo sexo. $\mathrm{Na}$ hipótese, a intepretação judicial ou a discricionariedade do Juiz, seja por que ângulo se queira ver, não tem o alcance de criar direito material, sob pena de invasão da esfera de competência do Poder Legislativo e violação do princípio republicano de separação (harmônica) dos poderes. Ainda que desejável o reconhecimento jurídico dos efeitos civis de uniões de pessoas do mesmo sexo, não passa, a hipótese, pelo casamento, instituto, aliás, que já da mais remota antiguidade tem raízes não somente na regulação do patrimônio, mas também na legitimidade da prole

320 Sentença do Estado do Rio de Janeiro. Disponível em: http://www.direitohomoafetivo.com.br/anexos/juris/1207_888e650a59881fd7780d4889636b01c6.pd. Acesso em 12 jul. 2015. 
resultante da união sexual entre homem e a mulher. Da mesma forma, não há falar em lacuna legal ou mesmo de direito, sob a afirmação de que o que não é proibido é permitido, porquanto o casamento homossexual não encontra identificação no plano da existência, isto é, não constitui suporte fático da norma, não tendo a discricionariedade do Juiz a extensão preconizada de inserir elemento substancial na base fática da norma jurídica, ou, quando não mais, porque o enunciado acima, não cria direito positivo. Tampouco sob inspiração da constitucionalização do direito civil mostra-se possível ao Juiz fundamentar questão de tão profundo corte, sem que estejam claramente definidos os limites do poder jurisdicional. Em se tratando de discussão que tem centro a existência de lacuna da lei ou de direito, indesviável a abordagem das fontes do direito e até onde o Juiz pode com elas trabalhar. Ainda no que tange ao patrimônio, o direito brasileiro oferta às pessoas do mesmo sexo, que vivam em comunhão de afeto e patrimônio, instrumentos jurídicos válidos e eficazes para regular, segundo seus interesses, os efeitos materiais dessa relação, seja pela via contratual ou, no campo sucessório, a via testamentária. A modernidade no direito não está em vê-lo somente sob o ângulo sociológico, mas também normativo, axiológico e histórico.

APELAÇÃO DESPROVIDA.

Sobreveio recurso especial apoiado na alínea "a" do permissivo constitucional, no qual se alega ofensa ao art. 1.521 do Código Civil de 2002, aduzindo as recorrentes que o mencionado dispositivo - que prevê os impedimentos para o casamento - não indica como tal a identidade de sexos.

Assim, aplicar-se-ia a regra segundo a qual, no direito privado, o que não é expressamente proibido é permitido, conclusão que autoriza as recorrentes a se habilitarem para o casamento.

Em 25/10/2011 a $4^{\text {a }}$ Turma do Superior Tribunal de Justiça, no julgamento do REsp 1.183.378 - RS, de relatoria do Ministro Luis Felipe Salomão, permitiu a habilitação para o casamento das duas mulheres do Rio Grande do Sul:

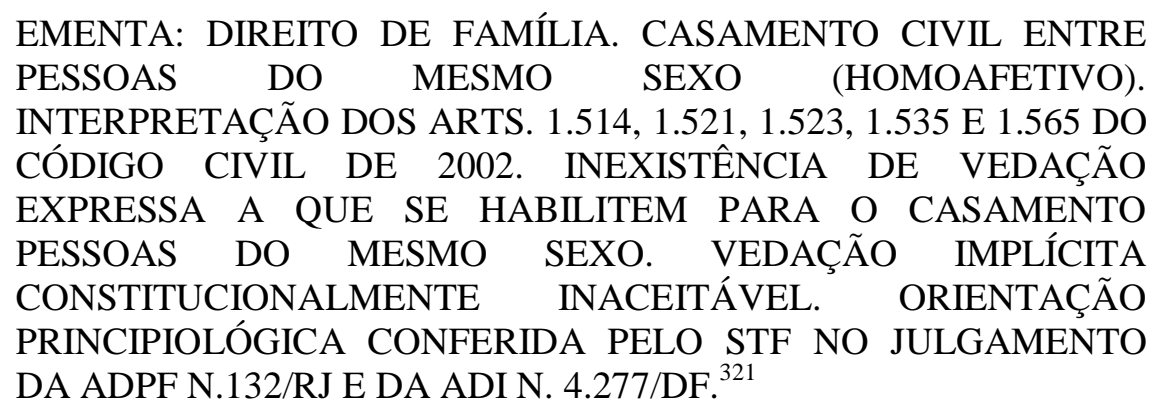

\footnotetext{
$321 \quad$ Recurso Especial $\quad N^{\circ} \quad 1183378 / R S . \quad$ Disponível em: http://ww2.stj.jus.br/processo/revista/documento/mediado/?componente=ATC\&sequencial=18538707\&num _registro $=$ Acesso em 12 jul. 2015.
} 
No entendimento de que o Superior Tribunal de Justiça, cumprindo sua missão de uniformizar o direito infraconstitucional, não pode conferir à lei uma interpretação que não seja constitucionalmente aceita:

1. Embora criado pela Constituição Federal como guardião do direito infraconstitucional, no estado atual em que se encontra a evolução do direito privado, vigorante a fase histórica da constitucionalização do direito civil, não é possível ao STJ analisar as celeumas que lhe aporta "de costas" para a Constituição Federal, sob pena de ser entregue ao jurisdicionado um direito desatualizado e sem lastro na Lei Maior. Vale dizer, o Superior Tribunal de Justiça, cumprindo sua missão de uniformizar o direito infraconstitucional, não pode conferir à lei uma interpretação que não seja constitucionalmente aceita.

Com fulcro no julgamento conjunto da ADPF n. 132/RJ e da ADI n. 4.277/DF pelo Supremo Tribunal Federal:

2. O Supremo Tribunal Federal, no julgamento conjunto da ADPF n. 132/RJ e da ADI n. 4.277/DF, conferiu ao art. 1.723 do Código Civil de 2002 interpretação conforme à Constituição para dele excluir todo significado que impeça o reconhecimento da união contínua, pública e duradoura entre pessoas do mesmo sexo como entidade familiar, entendida esta como sinônimo perfeito de família.

3. Inaugura-se com a Constituição Federal de 1988 uma nova fase do direito de família e, consequentemente, do casamento, baseada na adoção de um explícito poliformismo famíliar em que arranjos multifacetados são igualmente aptos a constituir esse núcleo doméstico chamado "família", recebendo todos eles a "especial proteção do Estado". Assim, é bem de ver que, em 1988, não houve uma recepção constitucional do conceito histórico de casamento, sempre considerado como via única para a constituição de família e, por vezes, um ambiente de subversão dos ora consagrados princípios da igualdade e da dignidade da pessoa humana. Agora, a concepção constitucional do casamento- diferentemente do que ocorria com os diplomas superados - deve ser necessariamente plural, porque plurais também são as famílias e, ademais, não é ele, o casamento, o destinatário final da proteção do Estado, mas apenas o intermediário de um propósito maior, que é a proteção da pessoa humana em sua inalienável dignidade.

Sobre o pluralismo familiar:

4. O pluralismo familiar engendrado pela Constituição - explicitamente reconhecido em precedentes tanto desta Corte quando do STF - impede se pretenda afirmar que as famílias formadas por pares homoafetivos sejam menos dignas de proteção do Estado, se comparadas com aquelas apoiadas na tradição e formadas por casais heteroafetivos.

5. O que importa agora, sob a égide da Carta de 1988, é que essas famílias multiformes recebam efetivamente a "especial proteção do Estado", e é tão somente em razão desse desígnio de especial proteção que a lei deve facilitar a conversão da união estável em casamento, ciente o constituinte que, pelo casamento, o Estado melhor protege esse núcleo doméstico chamado família. 
Essas famílias multiformes, reconhecidas pela Carta Magna, devem ser protegidas:

6. Com efeito, se é verdade que o casamento civil é a forma pela qual o Estado melhor protege a família, e sendo múltiplos os arranjos familiares reconhecidos pela Carta Magna, não há de ser negada essa via a nenhuma família que por ela optar, independentemente de orientação sexual dos partícipes, uma vez que as famílias constituídas por pares homoafetivos possuem os mesmos núcleos axiológicos daquelas constituídas por casais heteroafetivos, quais seja, a dignidade das pessoas de seus membros e o afeto.

7. A igualdade e o tratamento isonômico supõem o direito a ser diferente, o direito à auto-afirmação e a um projeto de vida independente de tradições e ortodoxias. Em uma palavra: o direito à igualdade somente se realiza com plenitude se é garantido o direito à diferença. Conclusão diversa também não se mostra consentânea com um ordenamento constitucional que prevê o princípio do livre planejamento familiar ( $\$ 7^{\circ}$ do art. 226). E é importante ressaltar, nesse ponto, que o planejamento familiar se faz presente tão logo haja a decisão de duas pessoas em se unir, com escopo de constituir família, e desde esse momento a Constituição lhes franqueia ampla liberdade de escolha pela forma em que se dará a união.

Quanto aos artigos 1.514, 1.521, 1.523, 1.535 e 1.565 todos do Código Civil:

8. Os arts. $1.514,1.521,1.523,1.535$ e 1.565 , todos do Código Civil de 2002, não vedam expressamente o casamento entre pessoas do mesmo sexo, e não há como se enxergar uma vedação implícita ao casamento homoafetivo sem afronta a caros princípios constitucionais, como o da igualdade, o da não discriminação, o da dignidade da pessoa humana e os do pluralismo e livre planejamento familiar.

É o Poder Judiciário e não o Poder Legislativo que exerce um papel de proteção, pois tem compromisso apenas com a lei e a Constituição:

9. Não obstante a omissão legislativa sobre o tema, a maioria, mediante seus representantes eleitos, não poderia mesmo "democraticamente" decretar a perda de direitos civis da minoria pelo qual eventualmente nutre alguma aversão. Nesse cenário, em regra é o Poder Judiciário - e não o Legislativo - que exerce um papel contramajoritário e protetivo de especialíssima importância, exatamente por não ser compromissado com as maiorias votantes, mas apenas com a lei e com a Constituição, sempre em vista a proteção dos direitos humanos fundamentais, sejam eles das minorias, sejam das maiorias. Dessa forma, ao contrário do que pensam os críticos, a democracia se fortalece, porquanto esta se reafirma como forma de governo, não das maiorias ocasionais, mas de todos.

10. Enquanto o Congresso Nacional, no caso brasileiro, não assume, explicitamente, sua coparticipação nesse processo constitucional de defesa e proteção dos socialmente vulneráveis, não pode o Poder Judiciário demitirse desse mister, sob pena de aceitação tácita de um Estado que somente é "democrático" formalmente, sem que tal predicativo resista a uma mínima investigação acerca da universalização dos direitos civis. 
O Ministro Raul Araújo, que também havia acompanhado o relator retificou seu voto. Segundo ele, o caso envolve interpretação da Constituição Federal e, portanto, seria competência do STF. Para o Ministro, o reconhecimento à união homoafetiva dos mesmos efeitos jurídicos da união estável entre homem e mulher, da forma como já decidido pelo STF, não alcança o instituto do casamento. Por isso, ele não conheceu do recurso e ficou vencido. Portanto, por 4 votos a 1 o STJ reconheceu o casamento civil entre pessoas do mesmo sexo. ${ }^{322}$

É importante frisar que a decisão da $4^{\mathrm{a}}$ Turma não tem efeito vinculante, isto é, aplica-se somente ao caso concreto julgado, mas abriu um precedente.

A partir desse julgamento, cada Estado, por meio de seus Tribunais, aos poucos, foi autorizando ou não o casamento civil de pessoas do mesmo sexo.

Em decisão unânime, em 27/09/2012, a 8 a Câmara Cível do Tribunal de Justiça do Rio Grande do Sul reconheceu a possibilidade de que a união estável entre dois homens fosse convertida em casamento.

Apelação Cível No 70048452643, Oitava Câmara Cível, Relator Ricardo Moreira Lins Pasti, data do julgamento: 27/09/2012.

Ementa: APELAÇÃO CÍVEL. CONVERSÃO DE UNIÃO ESTÁVEL HOMOAFETIVA EM CASAMENTO. CASAMENTO ENTRE PESSOAS DO MESMO SEXO. POSSIBILIDADE JURÍDICA DO PEDIDO. DESCONSTITUIÇÃO DA SENTENÇA PARA REGULAR PROCESSAMENTO DO FEITO. 1. Tendo em vista o julgamento da ADI $n^{\circ} 4.277$ e da ADPF $n^{\circ} 132$, resta superada a compreensão de que se revela juridicamente impossível o reconhecimento de união estável, em se tratando de duas pessoas do mesmo sexo. 2. Considerando a ampliação do conceito de entidade familiar, não há como a omissão legislativa servir de fundamento a obstar a conversão da união estável homoafetiva em casamento, na medida em que o ordenamento constitucional confere à família a "especial proteção do Estado", assegurando, assim, que a conversão em casamento deverá ser facilitada (art. 226, § $3^{\circ}, \mathrm{CF} / 88$ ). 3. Inexistindo no ordenamento jurídico vedação expressa ao casamento entre pessoas do mesmo sexo, não há que se cogitar de vedação implícita, sob pena de ofensa aos princípios constitucionais da igualdade, da não discriminação, da dignidade da pessoa humana e do pluralismo e livre planejamento familiar. Precedente do STJ. 4. Afirmada a possibilidade jurídica do pedido de conversão, imperiosa a desconstituição da sentença,

322 Recurso Especial $\quad \mathrm{N}^{\mathrm{o}}$ 1.183.378-RS. Disponível em: http://ww2.stj.jus.br/processo/revista/documento/mediado/?componente=ATC\&sequencial=18538707\&num registro $=$ Acesso em 11 jul. 2015. 
a fim de permitir o regular processamento do feito. APELO PROVIDO. ${ }^{323}$

O relator do recurso, Desembargador Ricardo Moreira Lins Pasti, salientou que efetivamente o Código Civil, ao regular a realização do casamento, refere claramente que se trata da união entre um homem e uma mulher. Contudo, observou que decisão do Superior Tribunal de Justiça (REsp 1.183.378/RS) reconheceu a possibilidade jurídica do casamento homoafetivo por considerar que o Código Civil não o veda expressamente.

"Sem margem a dúvidas, os indivíduos devem ser livres para escolher o parceiro conjugal", considerou o Desembargador. "Permitir que heterossexuais se casem e não os homossexuais, é ato discriminatório, é ato atentatório à igualdade perante a lei”

Lembrou, ainda, que a questão foi enfrentada também pelo Supremo Tribunal Federal (ADI No 4277 e ADPF No 132), confirmando o entendimento pela possibilidade da união entre pessoas do mesmo sexo. "Se é juridicamente possível o reconhecimento de uma união estável homoafetiva, (...) não há por que não se permitir que seja convertida em casamento, aliás, como recomenda o art. 226, $\S 3^{\circ}$, da Constituição federal, ao determinar que a lei facilite essa conversão"

Acompanhando o voto do relator, o Desembargador Rui Portanova lembrou o julgamento de casamento homoafetivo ocorrido em 11/09/2008, Apelação Cível No 70025659723, TJRS, $8^{\text {a }}$ Câmara Cível, Relator Claudir Fedelis Faccenda, do qual participou. Na ocasião, votou a favor do pedido, mas, com os votos contrários dos demais magistrados, acabou vencido. Os comentários do Desembargador Rui Portanova podem ser vistos nas páginas 211 e 212 desta dissertação. ${ }^{324}$

Também, decisão inédita no Rio Grande do Norte, Apelação Cível no 2012.00.30938, de 23/08/2012, Relatora Desembargadora Sulamita Bezerra Pacheco (Juíza Convocada), converte união estável homoafetiva em casamento.

Os desembargadores da $3^{\text {a }}$ Câmara Cível do Tribunal de Justiça decidiram, à unanimidade dos votos, pela conversão em casamento de uma união estável homoafetiva,

\footnotetext{
${ }^{323}$ Apelação Cível. N No $^{2} 0048452643$ TJRS. Conversão de União Estável Homoafetiva em Casamento. Disponível em: http://www.tjrs.jus.br/busca/search?q=\&entsp=a_politica-site\&wc $m c=1 \& o e=U T F-8 \& i e$. Acesso em 05 jul. 2015.

${ }^{324}$ TJ - RS reconhece possibilidade de casamento homoafetivo. Disponível em: http://www.conjur.com.br/2012-set-27/tj-rs-anula-decisao-nao-reconheceu-casamento... Acesso em 08 out. 2012.
} 
relativa a um casal que convive como se casados fossem há quase uma década. A decisão configura o primeiro caso na história da jurisprudência potiguar.

De acordo com a relatora, desembargadora Sulamita Bezerra Pacheco (juíza convocada),

\section{$[\ldots]$}

"a opção sexual do ser humano voltada à formação da família, não deve ser motivo de críticas destrutivas, mas sim de integral proteção estatal, até porque, como há muito apregoou o poeta Machado de Assis em seu primeiro romance denominado Ressureição "Cada qual sabe amar a seu modo: o modo pouco importa; o essencial é que saiba amar"”.

Ao final, a desembargadora sugere o envio do inteiro teor do citado voto à Corregedoria Geral da Justiça, com o fim de examinar a possibilidade da edição de Provimento tratando acerca da Conversão da União Estável (quer heteroafetiva quer homoafetiva) em casamento, de modo a sanear administrativamente outras querelas dessa natureza, a exemplo de outros Tribunais de Justiça (dentre eles os de São Paulo e Distrito Federal), evitando-se a necessidade de utilização da Máquina Judiciária, dada a eficácia erga omnes e efeito vinculante da decisão do Pleno do STF, lançada na ADPF 132-RJ e na ADI $4277-D^{325}$

Em 19/07/2012, o Conselho Superior da Magistratura do Estado de São Paulo confirma sentença que determinou a conversão de união estável homoafetiva em casamento. Apelação Cível No 0004335-34.2012.8.26.0037, da Comarca de Araraquara, em que é apelante o Ministério Público do Estado de São Paulo, Corregedor Geral da Justiça e Relator José Renato Nalini.

\section{VOTO}

REGISTRO CIVIL DAS PESSOAS NATURAIS - Recurso interposto contra sentença que deferiu o registro da conversão de união estável homoafetiva em casamento - Orientação emanada em caráter definitivo pelo Supremo Tribunal Federal (ADI 4277), seguida pelo Superior Tribunal de Justiça (REsp 1.183.378) - Impossibilidade de a via administrativa alterar a tendência sacramentada na via jurisdicional Recurso não provido.

\section{$[\ldots]$}

325 Tribunal de Justiça do Rio Grande do Norte. Apelação Cível no 2012.003093-8. Disponível em: www.tjrn.jus.br. Acesso em 23 ago. 2012. 
Embora não haja hierarquia entre cortes judiciárias, o Supremo Tribunal Federal tem por atribuição a guarda precípua da Constituição da República e o Superior Tribunal de Justiça a missão de unificar a interpretação do ordenamento em todo o Brasil.

Ambos decidiram ser possível o reconhecimento da proteção jurídica a conviventes do mesmo sexo. As ementas da ADI 4277-DF, 5.5.2011, relatoria do atual Presidente do STF, Ministro Ayres Brito, são eloquentes:

Proibição de discriminação das pessoas em razão do sexo, seja no plano da dicotomia homem/mulher (gênero), seja no plano da orientação sexual de cada qual deles. A proibição do preconceito como capítulo do constitucionalismo fraternal. Homenagem ao pluralismo como valor sociopolítico-cultural. Liberdade para dispor da própria sexualidade, inserida na categoria dos direitos fundamentais do indivíduo, expressão que é da autonomia da vontade, Direito à intimidade e à vida privada. Cláusula pétrea.

Tratamento Constitucional da Instituição da Família. Reconhecimento de que a Constituição Federal não empresta ao substantivo "família" nenhum significado ortodoxo ou da própria técnica jurídica. A família como categoria sócio-cultural e princípio espiritual. Direito subjetivo de constituir família. Interpretação não-reducionista.

\section{$[\ldots]$}

Como servos da Constituição - interpretada por aquele Colegiado que o pacto federativo encarregou guarda-la- os juízes e órgãos do Poder Judiciário não podem se afastar da orientação emanada em caráter definitivo pelo STF.

É por isso que, doravante, os dispositivos legais e Constitucionais relativos ao casamento e à união estável não podem mais ser interpretados à revelia da nova acepção jurídica que lhes deram o Supremo Tribunal Federal e o Superior Tribunal de Justiça." 326

Em maio de 2013, doze Estados e o Distrito Federal já autorizavam o casamento civil de pessoas do mesmo sexo, por meio de provimentos das corregedorias dos respectivos Tribunais de Justiça. São eles: Alagoas, Sergipe, Espírito Santo, Bahia, Piauí, São Paulo, Ceará, Mato Grosso do Sul, Paraná, Rondônia, Santa Catarina, Paraíba e Distrito Federal. $^{327}$

\footnotetext{
326 Apelação Cível, $\quad \mathrm{N}^{\circ}$ 0004335-34.2012.8.26.0037. Disponível em: http://www.direitohomoafetivo.com.br/imprime-jurisprudencia.php?ordem=1276,122 ... Acesso em 26 jul. 2012.

${ }^{327}$ Tribunais de 12 estados e do DF já autorizam casamento civil de pessoas do mesmo sexo. Disponível em: http://oglobo.globo.com/pais/tribunais-de-12-estdos-e-odf-ja-autorizam-casamento-c... Acesso em 10 mai. 2013.
} 
Para concretizar a união estável, o casal homossexual precisava seguir os trâmites em cartório. Para o casamento, eles pediam a conversão da união estável em casamento e isso ficava a critério de cada cartório, que podia ou não conceder.

Para padronização e solução dessas controvérsias em todo o território nacional, o IBDFAM (Instituto Brasileiro de Direito de Família), em dezembro de 2012, o Partido Socialismo e Liberdade (PSOL) e a Associação dos Registradores de Pessoas Naturais do Rio de Janeiro (ARPEN/RJ) protocolaram no CNJ (Conselho Nacional de Justiça) pedido para que regulamente em âmbito nacional o casamento civil entre pessoas do mesmo sexo.

Em ambos os pedidos, ou seja, do IBDFAM e do PSOL e da ARPEN, as entidades argumentam que, diante da decisão do Supremo Tribunal Federal (STF) de reconhecer a união estável homoafetiva, ela deve se submeter às mesmas regras e consequências da união estável heteroafetiva.

Para o PSOL e a ARPEN, uma das consequências da união estável é a possibilidade de ser convertida em casamento civil. Diante disso, as entidades pedem ao Conselho que emita ato administrativo em que determine que os cartórios reconheçam essa conversão, assim como realizem o casamento civil de casais do mesmo sexo, diretamente, sem a necessidade de prévia união estável. ${ }^{328}$

Assim, em 14 de maio de 2013, o Conselho Nacional de Justiça emitiu a Resolução $\mathrm{N}^{\mathrm{o}} 175$.

\section{RESOLUÇÃO No 175 DO CONSELHO NACIONAL DE JUSTIÇA, DE 14 DE MAIO DE 2013.}

Dispõe sobre a habilitação, celebração de casamento civil, ou de conversão de união estável em casamento, entre pessoas de mesmo sexo.

O PRESIDENTE DO CONSELHO NACIONAL DE JUSTIÇA, no uso de suas atribuições constitucionais e regimentais,

CONSIDERANDO a decisão do plenário do Conselho Nacional de Justiça, tomada no julgamento do Ato Normativo $\mathrm{n}^{\mathrm{o}}$ 000262665.2013.2.00.0000, na 169 ${ }^{\text {a }}$ Sessão Ordinária, realizada em 14 de maio de 2013;

CONSIDERANDO que o Supremo Tribunal Federal, nos acórdãos prolatados em julgamento da ADPF 132/RJ e da ADI 4277/DF,

328 Entidades pedem ao CNJ regulamentação do casamento civil homossexual. Disponível em: http://www.editoramagister.com/noticia_24320522_ENTIDADES_PEDEM_AO_CNJ_REGULAMENTAC OA_DO_CASAME... Acesso em 17 abr. 2013. 
reconheceu a inconstitucionalidade de distinção de tratamento legal às uniões estáveis constituídas por pessoas de mesmo sexo;

CONSIDERANDO que as referidas decisões foram proferidas com eficácia vinculante à administração pública e aos demais órgãos do Poder Judiciário;

CONSIDERANDO que o Superior Tribunal de Justiça, em julgamento do RESP 1.183.378/RS, decidiu inexistir óbices legais à celebração de casamento entre pessoas de mesmo sexo;

CONSIDERANDO a competência do Conselho Nacional de Justiça, prevista no art. 103-B, da Constituição Federal de 1988;

\section{RESOLVE:}

Art. $1^{\circ}$ É vedada às autoridades competentes a recusa de habilitação, celebração de casamento civil ou de conversão de união estável em casamento entre pessoas de mesmo sexo.

Art. $2^{\circ}$ A recusa prevista no artigo $1^{\circ}$ implicará a imediata comunicação ao respectivo juiz corregedor para as providências cabíveis.

Art. $3^{\circ}$ Esta resolução entra em vigor na data de sua publicação.

Ministro Joaquim Barbosa - Presidente ${ }^{329}$

A justificativa do presidente do CNJ Joaquim Barbosa foi tornar efetiva a decisão do STF que reconheceu, em 2011, a legalidade da união estável entre pessoas do mesmo sexo. Qualificou como contrassenso ter de esperar que o Congresso Nacional estabeleça a norma e afirmou que os cartórios estão descumprindo a decisão do STF, que é vinculante. Assim, o Conselho está removendo obstáculos administrativos à efetivação da decisão. ${ }^{330}$

Em entrevista ao Consultor Jurídico, o professor Álvaro Villaça Azevedo, presidente da Comissão de Estudos de Direito de Família do Instituto dos Advogados de São Paulo (IASP), afirmou que a fundamentação do Ministro Joaquim Barbosa está equivocada.

Jamais poderia haver conversão de união estável homoafetiva para casamento, pois o Supremo Tribunal Federal não reconheceu a união estável homoafetiva. O Supremo admitiu a proteção do casal homoafetivo, dando a eles os mesmos direitos, mas não a união estável. Explica, ainda, que o Ministro poderia ter usado como fundamento

\footnotetext{
${ }^{329}$ Resolução $N^{\circ}$ 175, de 14 de maio de 2013. Disponível em: www.cnj.jus.br/imprensa/resolucao n $\_$175.pdf. Acesso em 25 mai. 2013

330 Rafael Baliardo. CNJ autoriza casamento gay em cartórios. Disponível em: http://www.conjur.com.br/2013-mai-14/cnj-determina-cartorios-convertam-uniao-esta... Acesso em 15 mai. 2013.
} 
decisão do Superior Tribunal de Justiça que admitiu o casamento entre duas lésbicas. ${ }^{331}$

Em 21/05/2013, o PSC (Partido Social Cristão) entrou com um Mandado de Segurança- MS 32077 MC/DF, com pedido de liminar no Supremo Tribunal Federal pedindo a suspensão da Resolução 175, do CNJ, de 14/05/2013, sob o fundamento de que o CNJ se apropriou de prerrogativas do Congresso Nacional e do PSC, por ter aprovado uma norma que não passou pelo processo legislativo. Está claro para a sociedade que o direito da união homoafetiva existe, porém esta deve ser definida por lei. ${ }^{332}$

Em 28/05/2013, o Ministro Luiz Fux, do Supremo Tribunal Federal, decidiu extinguir o Mandado de Segurança - MS 32077 MC/DF, impetrado pelo PSC (Partido Social Cristão) contra a Resolução 175 do Conselho Nacional de Justiça, tendo em vista que o Mandado de Segurança não é o procedimento adequado para contestar a regra. Segundo o Ministro, a Resolução do CNJ qualifica-se como uma "lei em tese" e, nestes casos, a Súmula 266 do STF não permite que a regra seja atacada por meio de Mandado de Segurança. ${ }^{333}$

\author{
MS 32077 MC/DF - DISTRITO FEDERAL \\ MEDIDA CAUTELAR EM MANDADO DE SEGURANÇA \\ Relator: Ministro Luiz Fux \\ Julgamento: 28/05/2013 \\ Impetrante: Partido Social Cristão - PSC \\ Impetrado: Presidente do Conselho Nacional de Justiça
}

Ementa: DIREITO CONSTITUCIONAL. DIREITO CIVIL. MANDADO DE SEGURANÇA. PARTIDO POLÍTICO COM REPRESENTAÇÃO NO CONGRESSO NACIONAL. LEGITIMIDADE "AD CAUSAM" RECONHECIDA. RESOLUÇÃO No 175 DO CNJ. VEDAÇÃO ÀS AUTORIDADES COMPETENTES DE RECUSA À HABILITAÇÃO, CELEBRAÇÃO DE CASAMENTO CIVIL OU CONVERSÃ̃O DA UNIÃO ESTÁVEL EM CASAMENTO. ATO NORMATIVO DOTADO DE GENERALIDADE, ABSTRAÇÃO E IMPESSOALIDADE. INADEQUAÇÃO DA VIA ELEITA (SÚMULA

\footnotetext{
331 Tadeu Rover. Para advogados, decisão do CNJ é válida, mas falta lei. Disponível em: http://www.conjur.com.br/2013-mai-14/advogados-dizem-decisao-cnj-valida-porem-... Acesso em 15 mai. 2013.

332 Elton Bezerra. PSC questiona resolução do CNJ sobre casamento gay. Disponível em: http://www.conjur.com.br/2013-mai-21/psc-stf-resolucao-cnj-casamento-homoafetivo... Acesso em 22 mai. 2013.

333 Rodrigo Haidar. Fux extingue processo que contesta casamento gay. Disponível em: http://www.conjur.com.br/2013-mai-28/luiz-fux-extingue-processo-psc-contest-casa... Acesso em 29 mai. 2013.
} 
$\mathrm{N}^{\circ} 266$ DO $\quad$ STF). CONSTITUCIONALIDADE DO ATO IMPUGNADO. COMPETÊNCIA NORMATIVA DO CNJ RECONHECIDA NA ADC $\mathrm{N}^{\circ} 12$, REL. MIN. AYRES BRITTO. POSSIBILIDADE DE O CNJ FORMULAR EX ANTE E IN ABSTRATO JUÍZOS ACERCA DA VALIDADE DE DADA SITUAÇÃO FÁTICA. MANDADO DE SEGURANÇA EXTINTO SEM RESOLUÇÃO DO MÉRITO.

O Partido Social Cristão (PSC) sustenta que a Resolução CNJ n 175/2013:

"não pode ter validade, sem ser objeto do devido Processo Legislativo, como prevê a Constituição Federal de 1988, em seu artigo 59 e seguintes, em que o Partido Social Cristão poderá exercer na sua plenitude as suas prerrogativas legais e Constitucionais, bem como, se manifestar, expressando a sua vontade, nos limites de sua orientação partidária, seguindo os princípios Cristãos e Estatutários que norteiam a vontade de seus Filiados e de seus Congressistas".

\section{$[\ldots]$}

E conclui:

"O poder dos Conselhos de editar atos regulamentares não significa que estes tenham total liberdade para tais regulamentações. Os Conselhos enfrentam, pois, duas limitações: uma, stricto sensu, pela qual não podem expedir regulamentos com caráter geral e abstrato, em face da reserva de lei; e a outra, lato sensu, pela impossibilidade de ingerência nos direitos e garantias fundamentais dos cidadãos. Presente, aqui, a cláusula de proibição de restrição a direitos e garantias fundamentais, que se sustenta na reserva de lei, também garantia constitucional."

Em sua decisão o Ministro Luiz Fux argumentou:

Nada obstante isso, e ainda em juízo de prelibação, entendo que o mandado de segurança, seja ele individual ou coletivo, revela-se instrumento inidôneo para impugnar a Resolução $n^{\circ}$ 175/2013, editada pelo Presidente do Conselho Nacional de Justiça. É que o ato ora fustigado possui nítido perfil normativo, na medida em que disciplina, de forma genérica, abstrata e impessoal, a habilitação, celebração de casamento civil, ou de conversão de união estável em casamento, entre pessoas de mesmo sexo.

\section{$[\ldots]$}

De fato, a referida Resolução, à semelhança das espécies normativas primárias, retira seu fundamento de validade diretamente da Lei Fundamental, e não de outro ato normativo que a tenha precedido. Em seus consideranda, a Resolução CNJ n ${ }^{\circ}$ 175/2013 claramente alude ao seu fundamento: as decisões proferidas por esta Suprema Corte, nos autos da ADPF $n^{\circ} 132 / \mathrm{RJ}$ e da ADI n ${ }^{\circ}$ 4277/DF, ambas de relatoria do Min. Ayres Britto, e a decisão proferida nos autos do REsp $\mathrm{n}^{\circ}$ 1.183.378/RS, Rel. Min. Luis Felipe Salomão. Em todos os casos, a controvérsia gravitou em torno do sentido do alcance da exegese do art. $226, \S 3^{\circ}$ da Constituição da República. É inobjetável, diante dessa constatação, que a Resolução $n^{\circ}$ $175 / 2013$, por buscar seu fundamento de validade no art. $226, \S 3^{\circ}$, da CRFB/88, na interpretação que lhe foi conferida pelo Supremo Tribunal 
Federal e pelo Superior Tribunal de Justiça, reveste-se de generalidade, autonomia, abstração e impessoalidade. Exatamente porque ostenta tais apanágios, a Resolução n ${ }^{\circ}$ 175/2013 qualifica-se como "lei em tese", razão por que não se submete ao controle jurisdicional pela via do mandado de segurança, atraindo, por isso, a incidência, na espécie, da vedação contida na Súmula no 266 desta Corte (STF. Súmula no 266. "não cabe mandado de segurança contra lei em tese").

Em casos como o dos autos, é irrelevante perquirir se o ato normativo fustigado reveste-se de natureza estritamente legal. O que importa verdadeiramente, e a despeito de sua forma, são os efeitos que produz no mundo dos fatos, se similares ou não aos de uma lei em sentido material ("lei em tese"). E, neste particular, os efeitos da Resolução n ${ }^{\circ}$ 175/2013 equiparam-se, estreme de dúvidas, àqueles ínsitos às demais espécies normativas primárias, constantes do catálogo do art. 59, da Lei Fundamental.

\section{$[\ldots]$}

Destarte, ante a sua natureza primária, atributo reconhecido inclusive pelo próprio Impetrante, a Resolução $\mathrm{n}^{\circ} 175 / 2013$ do $\mathrm{CNJ}$ expõe-se ao controle abstrato de constitucionalidade, e não pela via incidental do mandado de segurança.

Em 06/06/2013, o Partido Social Cristão - PSC entrou com Ação Direta de Inconstitucionalidade ADI 4966, Relator Ministro Gilmar Mendes, questionando a Resolução n ${ }^{\circ}$ 175, de 14 de maio de 2013 do Conselho Nacional de Justiça.

Em 26/08/2013, a Procuradoria Geral da República enviou parecer ao Supremo Tribunal Federal pelo conhecimento da ação, e no mérito, pela improcedência do pedido.

Em 09/01/2015 autos conclusos ao Relator. ${ }^{334}$

A Resolução 175/2013 do CNJ também vem sendo questionada pelo Poder Legislativo, por meio de dois projetos de decreto legislativo que visam sustar atos normativos do Poder Executivo. São eles:

1) Projeto de Decreto Legislativo $N^{\circ} 871 / 2013$, de autoria do Deputado Arolde de Oliveira (PSD/RJ), data de apresentação: 22/05/2013.

Ementa: Susta os efeitos da Resolução $n^{\circ}$ 175, de 2013, do Conselho Nacional de Justiça, que "dispõe sobre a habilitação, celebração de casamento civil, ou de conversão de união estável em casamento, entre pessoas do mesmo sexo.

$334 \quad$ ADI $4966 \quad-\quad$ Ação Direta de Inconstitucionalidade. Disponível em: http://www.stf.jus.br/portal/processo/verProcessoAndamento.asp?incidente=4419751 Acesso em 02 jul. 2015. 
Situação atual: 18/03/2015 - Designado Relator, D. Chico Alencar (PSOL-RJ). Aguardando parecer do Relator na Comissão de Constituição e Justiça e de Cidadania.

2) Projeto de Decreto Legislativo No 199 , de 2013, de autoria do Deputado Marcos Rogério.

A justificativa de ambos os projetos de decreto legislativo é o inciso XI, do art. 49, da Constituição Federal, que estabelece ser competência exclusiva do Congresso Nacional zelar pela preservação da sua competência legislativa em face da atribuição normativa dos outros Poderes.

O Conselho Nacional de Justiça tem previsão constitucional no artigo 103-B e sua competência é fixada no $\S 4^{\circ}$ do mesmo artigo. Possui, portanto, natureza jurídica administrativa de controle interno, consoante ADIN n. 3.367-DF. Todas as atribuições políticas buscam a autonomia e a independência do Judiciário, a partir de um controle iminentemente administrativo, isto é o que contém o art. 103-B, $\S 4^{\circ}$, I, da Constituição Federal.

Cabe uma reflexão sobre o assunto em pauta: existem regulamentos autônomos no nosso sistema jurídico?

Observa Alexandre Jorge Carneiro da Cunha Filho que o poder normativo do Estado é uno e exercido por seus diversos órgãos, preponderantemente pelo Poder Legislativo. Porém, o "bloco de legalidade" que pauta a conduta da Administração não é só a lei em sentido formal, mas o Direito como um todo, incluindo a Constituição e os princípios que regem o nosso ordenamento. Portanto, são muitas as dificuldade que se apresentam para o intérprete decidir se no desempenho do poder regulamentar, o Executivo extrapolou a autorização constitucional em questão. ${ }^{335}$

${ }^{335}$ CUNHA FILHO, Alexandre Jorge Carneiro da. Lei e regulamento: apontamentos sobre o caráter inovador inerente a todas as formas de manifestação do poder normativo estatal. BDA - Boletim de Direito Administrativo, São Paulo, NDJ, ano 31, n. 7, p. 856-894, jul. 2015. 


\subsection{As decisões do STF e do STJ abalaram a teoria da inexistência do casamento?}

Entende o professor Álvaro Villaça Azevedo que o art. 226 da Constituição Federal tem disposição meramente enunciativa, não sendo taxativa. Daí a possiblidade de inclusão jurisprudencial, em interpretação integrativa, bem como de elaboração de leis criativas dessa e de novas formas de casamento, sem alteração do texto constitucional.

E conclui: os autores costumam dizer que não há casamento quando os nubentes são do mesmo sexo. $\mathrm{Na}$ verdade, não existe casamento tradicional, figura típica como cuidada no Código Civil, embora, com o mesmo sexo, exista outra espécie de casamento, o casamento homoafetivo, que tem guarida no texto genérico do art. 226 da Constituição Federal. $^{336}$

Em artigo intitulado "Espécies Atuais de Casamento e de União Estável” o professor Álvaro Villaça Azevedo sustenta que

Após embates legislativos, doutrinários e jurisprudenciais, ficamos com as seguintes espécies atuais de casamento e de união estável: a) casamento civil típico; b) casamento civil atípico; c) casamento religioso, com efeitos civis, ou casamento religioso autônomo; d) união estável típica; e) união estável atípica.

$[\ldots]$

O casamento civil atípico é o que não foi regulado pelo Código Civil. Ele é atípico, porque a lei civil não o regulamentou, ou melhor, não o admitiu. Teve-o de fazer, ante o caso concreto, especificamente, o Superior Tribunal de Justiça, que criou a figura jurisprudencial do casamento homoafetivo.

\section{$[\ldots]$}

Ao seu turno, a união estável atípica ocorre da mesma forma que a típica, somente entre pessoas do mesmo sexo. ${ }^{337}$

De acordo com o professor Zeno Veloso:

Diante do posicionamento dos tribunais superiores, não se pode mais considerar inexistente do ponto de vista jurídico o casamento de duas pessoas do mesmo sexo no Brasil. A doutrina tem de ser alterada, para

\footnotetext{
${ }^{336}$ AZEVEDO, Álvaro Villaça. Direito de Família. Curso de Direito Civil. São Paulo: Atlas, 2013, p. 2 e 96. 337 AZEVEDO, Álvaro Villaça, Espécies Atuais de Casamento e de União Estável. Revista Nacional de Direito de Família e Sucessões. Lex Magister, IASP, jul./ago./2014, p. 7-19.
} 
considerar casamento inexistente, além de outras hipóteses, o enlace de três pessoas (!), e isso enquanto os costumes e os princípios morais vigentes na sociedade não se alterarem, para admitir esta forma de poliafetividade. $^{338}$

Muitas legislações declaram que a diversidade de sexos seja uma condição essencial para a existência do casamento. Outras, como a nossa, silenciam a respeito, mas deixam entrever nas entrelinhas, quando dispõe "homem e mulher", ou "marido e mulher".

Como vimos, no capítulo 3, em Portugal e na Argentina a Teoria do Casamento Inexistente era prevista explicitamente nos ordenamentos jurídicos e esta restou modificada pela alteração das respectivas legislações que previram textualmente a possibilidade do casamento entre pessoas do mesmo sexo.

Em Portugal o inciso "e" do artigo 1628 que previa ser juridicamente inexistente o casamento contraído por duas pessoas do mesmo sexo restou revogado pela Lei 9/2010.

Na Argentina, antes da modificação introduzida pela Lei 26.618/2010, o artigo 172 do Código Civil argentino previa que:

É indispensável para a existência do matrimônio o pleno e livre consentimento expressado pessoalmente pelo homem e pela mulher ante a autoridade competente para celebrá-lo. A segunda parte deste artigo previa que o ato que carecer de alguns destes requisitos não produzirá efeitos civis, ainda que as partes tenham agido de boa-fé.

Após a modificação, o art. 172 ficou com a seguinte redação:

É indispensável para a existência do matrimônio o pleno e livre consentimento expressado pessoalmente por ambos contraentes ante a autoridade competente para celebrá-lo. O matrimônio terá os mesmos requisitos e efeitos, independentemente de que os contraentes sejam de mesmo ou de sexo diferente. $\mathrm{O}$ ato que carecer de algum destes requisitos não produzirá efeitos civis mesmo que as partes estejam de boa-fé, salvo o disposto no artigo seguinte.

Assim, na Argentina, os requisitos da existência do matrimônio estão previstos, atualmente, no artigo 406:

Para a existência do matrimônio é indispensável o consentimento de ambos contraentes expressado pessoal e conjuntamente ante a autoridade competente para celebrá-lo, exceto o previsto neste Código para o matrimônio à distância. $\mathrm{O}$ ato que carece deste requisito não produz efeitos civis.

${ }^{338}$ VELOSO, Zeno. Nulidade e inexistência. In 10 anos de Vigência do Código Civil Brasileiro de 2002. Estudos em homenagem ao professor Carlos Alberto Dabus Maluf. São Paulo: Saraiva, 2013, p. 197. 
Entre nós, portanto, o que existe hoje, jurisprudencialmente, é o casamento homoafetivo, ou seja, o casamento civil atípico. Assim, por falta de mudança no Código Civil, a Teoria da Inexistência do Casamento não foi modificada. Embasamos este entendimento na lição do professor Carlos Alberto Dabus Maluf:

Não se deve confundir inexistência de um ato com invalidade. "Inexistência é matéria a ser tratada no estudo dos atos que devem ou não ser admitidos como jurídicos. Invalidade é matéria a ser tratada no estudo daqueles requisitos cuja falta nos atos determina sua nulidade. A inexistência é matéria de política. A invalidade é matéria de técnica jurídica. A inexistência é matéria a ser considerada pelo legislador, a invalidade é matéria a ser examinada pelo juiz". ${ }^{339}$ (grifos nossos)

\subsection{Necessidade de mudança do Código Civil e da Constituição Federal?}

Compartilhando do entendimento do professor Álvaro Villaça Azevedo de que o artigo 226 da Constituição Federal é meramente exemplificativo, pode-se concluir que este acolhe as uniões homoafetivas sem necessidade de mudança na Constituição Federal.

Quanto ao casamento, também não há necessidade de mudança constitucional, pois o texto da Constituição Federal não o veda expressamente.

Quanto ao Código Civil, faz-se necessária uma mudança legislativa para acolher a união homoafetiva e o casamento homoafetivo.

No Capítulo 9 será apresentado um esboço de Projeto de Lei.

\subsection{Conclusão}

No Brasil, há poucos anos atrás, o Poder Judiciário rejeitava os pedidos de habilitação de casamento entre pessoas do mesmo sexo por impossibilidade jurídica do pedido, tendo em vista ausência de suporte legal.

\footnotetext{
${ }^{339}$ MALUF, Carlos Alberto Dabus, MALUf, Adriana Caldas do Rego Freitas Dabus. Curso de Direito de Família. São Paulo: Saraiva, p. 196.
} 
No entanto, conforme argumentação do Desembargador Rui Portanova, na Apelação Cível, No 70025659723 do Tribunal de Justiça do Rio Grande do Sul, em 11 de setembro de 2008, em voto vencido, afirmou que: a impossibilidade jurídica do pedido ocorre somente quando há expressa proibição legal, conforme entendimento do Superior Tribunal de Justiça no julgamento do Recurso Especial No 820475-RJ de 02 de setembro de 2008 (página 151).

Tanto nas uniões homoafetivas quanto no casamento homoafetivo não se vislumbram qualquer vedação legal. Pelo contrário, tendo em vista ser o Direito um sistema ordenado e harmônico de normas, é importante reconhecer que os dispositivos constitucionais e da legislação ordinária que tratam do casamento precisam ser compatibilizados com outros dispositivos constitucionais como, por exemplo: o preâmbulo; art. $1^{\circ}$, II, III; art. $3^{\circ}$; art. $4^{\circ}$, II; art. $5^{\circ}$, caput, I, II, III, IV, X, XXXV, $\S 2^{\circ}$ e $3^{\text {o; }}$ art. 19, III; art. 193; art. 226, caput e $\S 4^{\circ}$.

Se o intuito da lei fosse afastar a possibilidade do casamento entre pessoas do mesmo sexo, ao invés de usar a expressão "homem e mulher" usaria "homem com mulher".

Logo, é lícito dizer que são os intérpretes e as interpretações que levam à impossibilidade de se admitir o casamento entre pessoas do mesmo sexo.

Além disso, no Brasil, vige o princípio da interpretação conforme a Constituição, o que implica dizer que os textos legais não são autossuficientes, mas que dependem de uma leitura dos princípios constitucionais, a fim de lhes dar suporte valorativo, integrando a regra jurídica ao ordenamento, como um todo harmônico.

Após a decisão histórica do Supremo Tribunal Federal, em 05 de maio de 2011, no julgamento das duas ações $\mathrm{ADI} n^{\circ}$ 4277/DF e ADPF $n^{\circ}$ 132/RJ, em que reconheceu a união contínua, pública e duradoura entre pessoas do mesmo sexo como entidade familiar, garantindo os mesmos direitos e deveres da união estável, inúmeros pedidos de conversão de união homoafetiva em casamento e de habilitação para o casamento bateram às portas do Poder Judiciário. 
As decisões a respeito do tema não eram pacíficas e dependiam do entendimento de cada julgador em cada Estado do país, embora a decisão fosse dotada de eficácia erga omnes e de efeito vinculante.

Afirmar que a decisão é dotada de eficácia erga omnes e que tem efeito vinculante significa dizer que além de ser uma decisão geral, que atinge a todos, também é uma decisão que vincula a todos, em geral, inclusive os integrantes do Poder Judiciário e da Administração Pública. Desse modo, não há para o administrador e nem para o magistrado espaço para a discricionariedade e nem para o livre convencimento.

Ao conceder força vinculante e erga omnes, o legislador intencionou evitar a incidência de decisões discrepantes nas matérias decididas pelo Supremo Tribunal Federal, em sede de controle de constitucionalidade abstrato, e assim, afastar a insegurança jurídica que é prejudicial à paz social.

As decisões favoráveis à conversão da união homoafetiva em casamento tiveram por fundamento os princípios da igualdade, da dignidade da pessoa humana e os objetivos fundamentais da República de construção de uma sociedade livre, justa e solidária, bem como promover o bem de todos, sem preconceitos de origem, raça, sexo, cor, idade e quaisquer outras formas de discriminação. Além disso, determina a Constituição Federal que todos são iguais perante a lei, sem distinção de qualquer natureza e que a família, base da sociedade tem especial proteção do Estado.

Quanto ao artigo 226, $\S 5^{\circ}$ da Constituição Federal foi alegado que tal dispositivo não necessariamente declara que casamento existe apenas entre homem e mulher, até porque "sociedade conjugal" não é "casamento", sendo certo que a primeira sempre pôde ser dissolvida pela "separação" e o segundo somente é dissolvido pelo divórcio.

Em que pese o voto do Senhor Ministro Ricardo Lewandowski, que aplicou, pelo processo de integração analógico, às uniões homoafetivas as "prescrições legais relativas às uniões estáveis heterossexuais, excluídas aquelas que exijam a diversidade de sexo para o seu exercício, até que sobrevenham disposições normativas específicas que regulem tais relações", a conclusão da Corte Suprema não encampou esse entendimento, ampliando assim o conceito de união estável, para nele incluir toda e qualquer relação duradoura, pública e contínua, com intuito de constituir família, independentemente do sexo ou orientação sexual do casal. 
Assim, na medida em que o matrimônio assegura direitos que não são conferidos àqueles que vivem em união estável, efeitos estes, inclusive, mais benéficos, resta evidenciado o interesse jurídico da conversão.

Um dos interesses do Estado em facilitar a conversão da união estável em casamento é trazer segurança jurídica à família e à sociedade. Ora, não se alcança essa segurança jurídica se for excluída qualquer entidade familiar do instituto do casamento.

Também foi mencionado pelos magistrados que a decisão do Supremo Tribunal Federal se reveste de um duplo efeito. Primeiro, para reconhecer a existência de mais um tipo de entidade familiar: o da união entre pessoas do mesmo sexo. Segundo, para estender os mesmo direitos e deveres dos companheiros nas uniões estáveis àqueles que optam pela relação homoafetiva - incluindo, aqui, o direito à conversão da união estável entre pessoas do mesmo sexo em casamento.

Em um dos julgados foi levantada a questão de que o Código Civil institui duas formas para os cônjuges receberem o matrimônio, uma formal por meio de processo de habilitação prevista nos artigos 1.511 e seguintes do Código Civil e outra de modo mais simplificado por meio da conversão de reconhecida anterior união estável vivida entre os companheiros. Assim, a habilitação prevista nos artigos 1.511 e seguintes não foi alcançada pelo julgado Excelso tendo em vista as vertentes conflitantes em relação à fundamentação dos Ministros Ricardo Lewandowisk, Gilmar Mendes e Cezar Peluso.

Com efeito, todos aqueles que vivenciaram união estável na forma prevista no artigo 1.723 do Código Civil, indistintamente se heterossexual ou homossexual, terão os mesmos direitos e deveres advindos desta relação jurídica, inclusive o de receberem matrimônio por meio do procedimento de conversão.

Finalmente, no entendimento de que o Superior Tribunal de Justiça, cumprindo sua missão de uniformizar o direito infraconstitucional, não pode conferir à lei uma interpretação que não seja constitucionalmente aceita e com fulcro no julgamento conjunto da ADPF No 132/RJ e ADI No 4.277/DF pelo Supremo Tribunal Federal julgou não existir vedação expressa a que se habilitem para o casamento pessoas do mesmo sexo. E ainda que a vedação implícita na interpretação dos artigos 1.514, 1.521, 1.523, 1.535, e 1.565 do Código Civil é constitucionalmente inaceitável, sob pena de ofensa aos princípios 
constitucionais da igualdade, da não discriminação, da dignidade da pessoa humana, e do pluralismo e livre planejamento familiar.

É possível verificar que o entendimento do Supremo Tribunal Federal foi no sentido de ampliar o conceito de união estável, para nele incluir toda e qualquer relação duradoura, pública e contínua, com intuito de constituir família, independentemente do sexo ou orientação sexual do casal.

Também é possível verificar que o Código Civil não veda expressamente a habilitação para o casamento e que a vedação implícita é constitucionalmente inaceitável.

É por isso que, doravante, os dispositivos legais e Constitucionais relativos ao casamento e à união estável não podem mais serem interpretados à revelia da nova acepção jurídica que lhes deram o Supremo Tribunal Federal e o Superior Tribunal de Justiça.

Em maio de 2013, doze Estados e o Distrito Federal já autorizavam o casamento civil de pessoas do mesmo sexo, por meio de provimentos das corregedorias dos respectivos Tribunais de Justiça. Porém, nos demais Estados não havia ainda tal uniformização.

Para padronização e solução dessas controvérsias em todo o território nacional, o IBDFAM (Instituto Brasileiro de Direito de Família), o PSOL (Partido Socialismo e Liberdade) e a ARPEN/RJ (Associação dos Registradores de Pessoas Naturais do Rio de Janeiro) protocolaram no CNJ (Conselho Nacional de Justiça) pedidos para que se regulamentasse, em âmbito nacional, o casamento civil entre pessoas do mesmo sexo.

Em ambos os pedidos, tanto IBDFAM quanto PSOL e ARPEN/RJ argumentavam que, diante da decisão do Supremo Tribunal Federal (STF) de reconhecer a união estável homoafetiva, ela deve se submeter às mesmas regras e consequências da união estável heteroafetiva.

Para o PSOL e a ARPEN, uma das consequências da união estável é a possibilidade de ser convertida em casamento civil. Diante disso, as entidades pedem ao Conselho que emita ato administrativo em que determine que os cartórios reconheçam essa conversão, assim como realizem o casamento civil de casais do mesmo sexo, diretamente, sem a necessidade de prévia união estável. 
Em 14 de maio de 2013, o Conselho Nacional de Justiça emitiu a Resolução $N^{\text {o }}$ 175 que dispõe sobre a habilitação, celebração de casamento civil, ou de conversão de união estável em casamento, entre pessoas do mesmo sexo.

Em 21 de maio de 2013, o PSC (Partido Social Cristão) entrou com um Mandado de Segurança - MS 32077 MC/DF, com pedido de liminar no Supremo Tribunal Federal pedindo a suspensão da Resolução 175, do CNJ, de 14/05/2013, sob o fundamento de que o CNJ se apropriou de prerrogativas do Congresso Nacional e do PSC, por ter aprovado uma norma que não passou pelo processo legislativo.

E, que o Partido Social Cristão poderá exercer na sua plenitude as suas prerrogativas legais e Constitucionais, bem como, se manifestar, expressando a sua vontade, nos limites de sua orientação partidária, seguindo os princípios Cristãos e Estatutários que norteiam a vontade de seus Filiados e de seus Congressistas.

Sabemos que o Brasil é um Estado laico e regido por normas, princípios e valores jurídicos. Ainda que a união homoafetiva e o casamento entre pessoas do mesmo sexo estejam autorizados, essa permissão ocorreu por via judicial, necessitando ainda de regulamentação legislativa.

Pela justificativa do Partido Social Cristão de exercer as suas prerrogativas legais e Constitucionais, nos limites de sua orientação partidária e seguindo os princípios Cristãos será respeitada a laicidade do Estado?

A ideia de pecado vem da religião e o Estado laico não pode embasar seus atos em concepções religiosas. Assim os livros sagrados e dogmas de qualquer religião não podem servir de fundamento para a criação das leis num Estado laico.

Em 28/05/2013, o Ministro Luiz Fux, do Supremo Tribunal Federal, decidiu extinguir o Mandado de Segurança - MS 32077 MC/DF tendo em vista que o Mandado de Segurança não é o procedimento adequado para contestar a regra. Segundo o Ministro, a Resolução do CNJ qualifica-se como uma "lei em tese" e, nestes casos, a Súmula 266 do STF não permite que a regra seja atacada por meio de Mandado de Segurança.

É que a Resolução 175 do CNJ possui nítido perfil normativo, na medida em que disciplina, de forma genérica, abstrata e impessoal, a habilitação, celebração de casamento civil, ou de conversão de união estável em casamento, entre pessoas do mesmo sexo. 
A referida Resolução, à semelhança das espécies normativas primárias, retira seu fundamento de validade diretamente da Lei Fundamental, e não de outro ato normativo que a tenha precedido. A Resolução 175/2013 por buscar seu fundamento de validade no art. 226 , § $3^{\circ}$, da CRFB/88, na interpretação que lhe foi conferida pelo Supremo Tribunal Federal e pelo Superior Tribunal de Justiça, reveste-se de generalidade, autonomia, abstração e impessoalidade. Exatamente porque ostenta tais apanágios, a Resolução $n^{\circ}$ 175/2013 qualifica-se como "lei em tese".

Destarte, a Resolução $n^{\circ}$ 175/2013 do CNJ expõe-se ao controle abstrato de constitucionalidade, e não pela via incidental do mandado de segurança.

Em 06/06/2013, o PSC (Partido Social Cristão) entrou com Ação Direta de Inconstitucionalidade ADI 4966, Relator Ministro Gilmar Mendes, questionando a Resolução no 175/2013 do CNJ.

A Resolução no 175/2013 do CNJ também vem sendo questionada pelo Poder Legislativo, por meio de dois projetos de decreto legislativo que visam sustar atos normativos do Poder Executivo. A justificativa de ambos os projetos é o inciso XI, do art. 49, da Constituição Federal, que estabelece ser competência exclusiva do Congresso Nacional zelar pela preservação da sua competência legislativa em face da atribuição normativa dos outros Poderes.

Como visto anteriormente, são muitas as dificuldades que se apresentam para o intérprete decidir se no desempenho do poder regulamentar, o Executivo extrapolou ou não a autorização constitucional em questão.

Entende o professor Álvaro Villaça Azevedo que atualmente existem as seguintes espécies de casamento e de união estável: o casamento civil típico e o casamento civil atípico, casamento religioso, com efeitos civis, união estável típica e união estável atípica.

O casamento civil atípico é o que não foi regulado pelo Código Civil. E este difere do típico, porque é entre pessoas do mesmo sexo e foi criado jurisprudencialmente pelo Superior Tribunal de Justiça.

A união estável atípica ocorre da mesma forma que a típica. Somente entre pessoas do mesmo sexo. 
Vimos que nos países onde a Teoria da Inexistência do Casamento restou modificada, houve alteração legislativa para acolher o casamento entre pessoas do mesmo sexo.

Portanto, por falta de mudança no Código Civil, a Teoria da Inexistência do Casamento ainda não foi modificada, embora existam jurisprudencialmente o casamento homoafetivo e a união homoafetiva. 


\section{A FILIAÇÃO HOMOPARENTAL}

O termo homoparentalidade designando a noção de que os pais ou mães da criança são homossexuais, foi inventado em 1996 pela APGL (Associação de pais e futuros pais gays e lésbicas) na França. $\mathrm{O}$ objetivo foi mostrar a capacidade e a competência de casais formados por pessoas do mesmo sexo em adotar crianças ou de se submeterem à reprodução artificial medicamente assistida. ${ }^{340}$

Em 1986, duas mulheres nos Estados Unidos, no Estado da Califórnia, formaram o primeiro casal lésbico a adotar legalmente uma criança, sendo hoje possível na grande maioria dos 50 estados norte-americanos. Na Europa, muitos países seguiram o exemplo da pioneira Dinamarca, que em 1999 permitiu a homossexuais ligados por união civil adotar o filho do companheiro ou companheira e dez anos depois, em 2009, aprovou a adoção de crianças por casal homossexual. A lista inclui Alemanha, Holanda, Bélgica, Suécia, Espanha, Noruega, Islândia, França, Inglaterra, País de Gales, Escócia, Luxemburgo e Irlanda.

Na África do Sul, a Suprema Corte legalizou a adoção por casais homossexuais em 2002, único país do continente a adotar a medida. Em Israel, em 2008, uma decisão do procurador-geral de Israel permitiu adoção para casais do mesmo sexo. O Uruguai foi o primeiro país latino-americano a legalizar a adoção por casais homossexuais, em 2009. A Argentina em 2010.

No Brasil, a adoção de crianças por casais homossexuais ganhou um impulso considerável com a decisão da $4^{\text {a }}$ Turma do Superior Tribunal de Justiça (STJ), em 27/04/2010, no Recurso Especial No 889.852-RS, que, por unanimidade, negou recurso do Ministério Público do Rio Grande do Sul contra decisão que permitiu a adoção de duas crianças por um casal de lésbicas. A decisão apontou que estudos não indicam qualquer inconveniência em que crianças sejam adotadas por casais homossexuais, importando mais a qualidade do vínculo e do afeto no meio familiar em que serão insertas.

Outra barreira ultrapassada veio em 2009, quando o Conselho Nacional de Justiça mudou o padrão da certidão de nascimento do tradicional "pai e mãe" para o termo

\footnotetext{
${ }^{340}$ BOISSON Marine, VERJUS Anne. Quand connaître, c'est reconnaître? Ce role de l'expertise familiale dans la production d'un sens commun du parent (homosexual). Droit et Société. No 60/2005. p.452.
} 
"filiação", abrindo caminho para o registro de crianças por casais do mesmo sexo e garantindo à criança todos os direitos sucessórios e patrimoniais, inclusive em caso de separação ou morte de um dos pais. ${ }^{341}$

Com relação à filiação entre casais do mesmo sexo, em nosso ordenamento jurídico, não há norma que a proíba, mas, não há legislação específica sobre o tema.

Com o advento da Carta Magna de 1988 e o reconhecimento das famílias monoparentais (artigo 226, § $4^{\circ}, \mathrm{CF}$ ) houve a total dissociação do estatuto jurídico do casamento e da união estável, do estatuto jurídico da filiação. Assim, a Constituição reconheceu que todos os indivíduos podem realizar o seu projeto parental independentemente da existência de vínculo matrimonial ou ligação afetiva permanente. Podem, também, ter um projeto parental unilateral, uma vez que a família monoparental possui a mesma dignidade que as outras formas de família.

Assegura, ainda, a Constituição Federal (artigo 226, § $7^{\circ}, \mathrm{CF}$ ) que o planejamento familiar fundado nos princípios da dignidade humana e da paternidade responsável, é de livre decisão do casal, vedada qualquer forma coercitiva no exercício desse direito. Regulamentando tal direito, a Lei 9.263/96 reconhece, em seu artigo $2^{\circ}$, que o planejamento familiar é o conjunto de ações de regulação de fecundidade que garanta direitos iguais de constituição, limitação ou aumento da prole pela mulher, pelo homem ou pelo casal, sendo direito de todo cidadão.

Ensinam os professores Carlos Alberto Dabus Maluf e Adriana Caldas do Rego Freitas Dabus Maluf que:

Na pós-modernidade pode-se definir como filho todo ser gerado de forma
natural ou mediante o emprego de técnicas de biotecnologia, de
reprodução artificial medicamente assistida, que pertence ao núcleo
familiar, equiparados entre si por força do art. $227, \S 6^{\circ}$, da CF, que veda
qualquer designação discriminatória no tocante à filiação, prevendo a
legitimidade a todos os filhos, independentemente de serem fruto do
casamento ou não, ou mesmo independentemente da forma de sua
geração. ${ }^{342}$

341 A adoção feita por homossexuais: batalhas e vitórias legais. Disponível em: http://www.senado.gov.br/noticias/Jornal/emdiscussao/adocao/relatos-reais-sobre-ado.. Acesso em 6 jan. 2014.

${ }^{342}$ MALUF, Carlos Alberto Dabus. MALUF Adriana Caldas do Rego Dabus. Curso de Direito de Família. São Paulo: Saraiva, p. 478. 


\subsection{A filiação na codificação civil brasileira}

No início do século XX, a legislação civil vigente era o Código Civil de 1916 (Lei $\mathrm{n}^{\mathrm{o}} 3.071$, de $1^{\mathrm{o}}$ de janeiro de 1916).

De acordo com esse diploma legal, somente o casamento constituía a família legítima (artigo 229), dividindo os filhos em quatro espécies: os legítimos, os legitimados, os ilegítimos e os adotivos.

Legítimos eram os filhos concebidos na constância do casamento. Para tanto, aplicava-se a presunção pater is est, prevista no artigo 338.

Legitimados eram os filhos resultantes do casamento dos pais, posteriormente à sua concepção ou ao seu nascimento, previsto no artigo 353, os quais eram equiparados aos filhos legítimos, de acordo com o artigo 352.

Filhos ilegítimos eram aqueles que não provinham de um casamento entre os pais, mas podiam ser reconhecidos voluntariamente pelos pais, conjunta ou separadamente, no próprio termo de nascimento, ou mediante escritura pública, ou por testamento, de acordo com o artigo 357. Quanto aos filhos ilegítimos incestuosos e os adulterinos não podiam ser objeto de reconhecimento voluntário ou forçado, de acordo com os artigos 358 e 364.

Quanto aos filhos adotivos, a adoção era constituída mediante escritura pública e pela qual se limitava o parentesco ao adotante e ao adotado, exceto quanto aos impedimentos matrimoniais.

Quanto à paternidade, manteve-se a mesma presunção do direito romano, considerando-se filiação legítima a concebida na constância do casamento, havendo a presunção pater is est prevista no artigo 338, pois se presumia como concebido na constância do casamento o filho nascido pelo menos 180 dias após ser estabelecida a convivência conjugal ou o nascido dentro dos 300 dias subsequentes à dissolução da sociedade conjugal por morte, desquite ou anulação. O Código falava em desquite, pois o divórcio só foi instituído em 1977, por força da emenda n.9 à Constituição Federal.

Com a Lei do divórcio, Lei 6.515, de 26.12.1977, artigo 51, estabeleceu-se a igualdade de condições entre todos os filhos, independentemente de sua natureza, quanto ao direito à herança. 
A Constituição Federal de 1988, de maneira taxativa, fixou regra de isonomia de direitos e deveres entre filhos oriundos ou não de casamento ou por adoção e proibiu quaisquer designações discriminatórias relativas à filiação, em seu artigo $227, \S 6^{\circ}$.

O Código Civil de 2002 (Lei n 10.406, de 10.01.2002), por meio do artigo 1.596, repetiu o dispositivo constitucional de isonomia de direitos e qualificações entre todos os filhos havidos ou não da relação de casamento ou por adoção.

Importante observar que a Lei n ${ }^{\circ} 12.010$, de 3 de agosto de 2009, conhecida como a "nova lei de adoção", alterou dispositivos do Estatuto da Criança e do Adolescente ECA (Lei nº 8.069 de 13 de junho de 1990), bem como dispositivos do Código Civil de 2002, com relação à adoção.

Com relação à presunção de paternidade, o Código Civil de 2002 repetiu, em seu artigo 1.597, as duas hipóteses de presunção de filiação na constância do casamento, fundadas na presunção pater is est, atribuindo a paternidade ao marido da mulher casada, se o filho nascer nos 180 dias que se seguirem após ser estabelecida a convivência conjugal ou se nascer nos 300 dias subsequentes à dissolução da sociedade conjugal, por morte, separação judicial, nulidade e anulação do casamento.

Ensina-nos o professor Jorge Shiguemitsu Fujita ${ }^{343}$ que, ao repetir a mesma fórmula pater is est existente no Código Civil de 1916, utilizou-se de um critério ora considerado ultrapassado, pois nem sempre a verdade jurídica, representada pela presunção relativa dos incisos I e II do artigo 1.597, coincide com a verdade biológica. E citando o professor Rui Geraldo Camargo Viana (A Família e a Filiação. Tese de Titularidade de Direito Civil apresentada na Faculdade de Direito da USP, 1996, p.12): "Pater est quem DNA demonstrat".

Porém, o artigo acima não tratou apenas das duas situações referidas no Código Civil de 1916, mas ampliou o rol de presunções da filiação nos incisos III, IV e V, nos seguintes termos:

Artigo 1.597. Presumem-se concebidos na constância do casamento os filhos:

$(\ldots)$

${ }^{343}$ FUJITA, Jorge Shiguemitsu. Filiação. 2 ed. São Paulo: Editora Atlas, 2011, p. 29. 
III - havidos por fecundação artificial homóloga, mesmo que falecido o marido;

IV - havidos, a qualquer tempo, quando se tratar de embriões excedentários, decorrentes da concepção artificial homóloga;

$\mathrm{V}$ - havidos por inseminação artificial heteróloga, desde que tenha prévia autorização do marido.

Leciona o doutrinador Caio Mário da Silva Pereira ${ }^{344}$ que se equivocou o legislador de 2002, em relação à filiação, ao referir-se sempre ao casamento, sem mencionar situações oriundas das relações de fato reconhecidas como União Estável, hoje entidade familiar protegida pelo Estado.

Sobre o artigo 1.597 a professora Regina Beatriz Tavares da Silva ${ }^{345}$ faz referência aos Enunciados de números 104, 105,106 e 107 da I Jornada de Direito Civil e Enunciado n. 257 da III Jornada de Direito Civil.

Enunciado n. 104 da I Jornada de Direito Civil:

Art. 1.597: no âmbito das técnicas de reprodução assistida envolvendo o emprego de material fecundante de terceiros, o pressuposto fático da relação sexual é substituído pela vontade (ou eventualmente pelo risco da situação jurídica matrimonial) juridicamente qualificada, gerando presunção absoluta ou relativa de paternidade no que tange ao marido da mãe da criança concebida, dependendo da manifestação expressa (ou implícita) da vontade no curso do casamento.

O Enunciado 105, aprovado na I Jornada de Direito Civil - Conselho da Justiça Federal, de setembro de 2002, recomenda:

Art. 1.597: as expressões "fecundação artificial", "concepção artificial” e "inseminação artificial" constantes, respectivamente, dos incisos III, IV, V do art. 1.597, deverão ser interpretadas como "técnica de reprodução assistida".

De acordo com o Enunciado 257, aprovado na III Jornada de Direito Civil Conselho da Justiça Federal, de 2004, recomenda-se que: essas presunções, por sua natureza, devem ser interpretadas restritivamente, "não abrangendo a utilização de óvulos doados e a gestação de substituição".

Dispõe o Enunciado 106, da I Jornada de Direito Civil:

Art. 1597, inc. III: para que seja presumida a paternidade do marido falecido, será obrigatório que a mulher, ao se submeter a uma das

344 PEREIRA, Caio Mário da Silva. Instituições de Direito Civil. Vol. V, 20 ed. Atualizada por Tânia da Silva Pereira. Rio de Janeiro: Forense, 2012, p. 323.

${ }^{345}$ SILVA, Regina Beatriz Tavares da. Código Civil Comentado. 6 ${ }^{a}$ ed. São Paulo: Saraiva, 2008, p. 1.742. 
técnicas de reprodução assistida com o material genético do falecido, esteja na condição de viúva, sendo obrigatório, ainda, que haja autorização escrita do marido para que se utilize seu material genético após sua morte.

Acerca do inciso IV, manifestou-se o Conselho da Justiça Federal, de acordo com o enunciado 107, aprovado na Jornada de Direito Civil de 2002:

Art. 1597, IV: finda a sociedade conjugal, na forma do art. 1.571, a regra do inciso IV somente poderá ser aplicada se houver autorização prévia, por escrito dos ex-cônjuges, para a utilização dos embriões excedentários, só podendo ser revogada até o início do procedimento de implantação desses embriões.

Tais incisos cuidam da chamada reprodução artificial assistida, utilizada por casais que, por não conseguirem procriar, recorrem a novos mecanismos da medicina genético-reprodutiva. Porém, apenas reconhecem a existência da reprodução assistida, sem, contudo, autorizá-la ou regulamentá-la. Até os dias de hoje, o que temos são regras deontológicas estabelecidas pelas Resoluções do Conselho Federal de Medicina, sendo que a última resolução é a Resolução do CFM 2013/2013.

A professora Maria Helena Diniz ${ }^{346}$ ensina que a reprodução humana assistida poderá dar-se pelos métodos ZIFT e GIFT. O método ZIFT concretiza a ectogênese ou fertilização in vitro, que consiste na retirada de óvulo da mulher para fecunda-lo na proveta, com sêmen do marido ou de outro homem, para depois introduzir o embrião no seu útero ou no de outra. O método GIFT dá origem à inseminação artificial, que se processa mediante a inoculação do sêmen na mulher, sem que haja qualquer manipulação externa de óvulo ou de embrião.

No caso de inseminação artificial, poderá haver inseminação homóloga, quando o material genético do filho provém do material genético dos pais, isto é, óvulo da mãe e espermatozoide do pai. Ou, ainda, inseminação heteróloga sendo aquela em que há material genético de pelo menos um terceiro: espermatozoide de doador e óvulo da esposa, ou óvulo de doadora e espermatozoide do marido, ou ambos, óvulo e espermatozoide, de doadores.

${ }^{346}$ DINIZ, Maria Helena. O Estado Atual do Biodireito. 8 ed. São Paulo: Saraiva. 2011, p. 610. 
De acordo com o professor Jorge Shiguemitsu Fujita ${ }^{347}$, nos tempos atuais, a filiação pode ser conceituada como sendo:

O vínculo que se estabelece entre pais e filhos, decorrente da fecundação natural ou da técnica de reprodução assistida homóloga, ou heteróloga, assim como em virtude da adoção ou de uma relação socioafetiva resultante da posse do estado de filho.

\subsection{Reprodução medicamente assistida e os casais homossexuais}

O desenvolvimento da pesquisa em Reprodução Humana Assistida (RHA), além de assegurar benefícios para a humanidade, trouxe também desafios e implicações éticas e jurídicas ao intervir na própria natureza biológica do ser humano.

A necessidade de se encontrar os limites, que se iniciam como éticos e que irão encontrar a sua formulação final no sistema jurídico, é de fundamental importância. $\mathrm{O}$ direito, então, é chamado a fazer parte desse diálogo interdisciplinar. Parece-nos que seja este o grande desafio do século XXI.

Na realidade da bioética e do direito de família, o que se vê é ocorrerem primeiro os julgamentos e num segundo momento os projetos de lei surgindo a fim de regulamentar tais situações. Temos hoje a tímida abordagem da lei civil sobre as presunções de paternidade, bem como o texto da última Resolução do Conselho Federal de Medicina, a

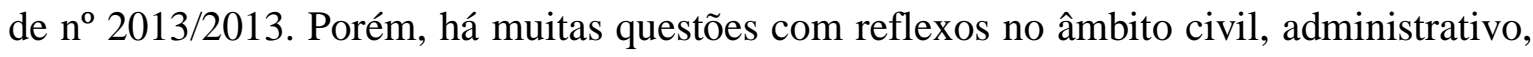
penal, previdenciário, tributário e processual, as quais não podem ser solucionadas por uma resolução.

\section{Algumas considerações devem ser tecidas. \\ Primeira consideração:}

A Constituição Federal (artigo 226, $\S 7^{\circ}$ ) estabelece que, fundado nos princípios da dignidade da pessoa humana e da paternidade responsável, o planejamento familiar é

${ }^{347}$ FUJITA, Jorge Shiguemitsu et al. Filiação na Contemporaneidade. In Direito de Família no Novo Milênio. Estudos em homenagem ao professor Álvaro Villaça Azevedo. São Paulo: Editora Atlas. 2010, p. 474. 
livre decisão do casal, vedada qualquer forma coercitiva por parte de instituições oficiais ou privadas.

De acordo ainda com a Constituição Federal (artigo 226), a família é a base da sociedade e, portanto, tem especial proteção do Estado, entendendo-se como entidade familiar a comunidade formada por ambos os genitores ou apenas um deles e seus descendentes, quer se origine do casamento (artigo 226, § $1^{\circ}$ ), da adoção (artigo 227, § $6^{\circ}$ ), da monoparentalidade (artigo 226, $\S 4^{\circ}$ ) e da união estável entre o homem e a mulher (artigo 226, § $3^{\circ}$ ).

Embora haja entendimentos de que a família e suas formas de constituição estão enumeradas num rol taxativo (numerus clausus), filiamo-nos à corrente dos que defendem um rol exemplificativo (numerurs apertus), pois não pode haver restrição ou proibição às pessoas de constituírem suas famílias da maneira que melhor entenderem, o que é assegurado pela Constituição Federal (artigo $1^{\circ}$, III - Princípio da Dignidade da Pessoa Humana) e também pelo Código Civil em seu artigo 1.513, que alerta ser defeso a qualquer pessoa, de direito público ou privado, interferir na comunhão de vida instituída pela família.

Dentro desse conceito mais amplo, e também após o julgamento pelo Supremo Tribunal Federal da ADI 4.277/DF e ADPF 132/RJ, em que exclui qualquer interpretação que impeça o reconhecimento da união contínua, duradoura e pública entre pessoas do mesmo sexo como "entidade familiar", entendida esta como sinônimo perfeito de família e com as mesmas regras e consequências da união estável heteroafetiva, não se pode excluir do âmbito do direito de família os relacionamentos de pessoas do mesmo sexo.

O Conselho Federal de Medicina, ao regulamentar tais práticas pela Resolução do CFM 1.358/1992, fez expressa referência a "toda a mulher". A Resolução do CFM 1957/2010, admite o uso das técnicas de reprodução assistida a "todas as pessoas capazes", que tenham solicitado o procedimento e cuja indicação não se afaste dos limites desta resolução e a Resolução do CFM 2013/2013 faz referência expressa à permissão das técnicas de RA (Reprodução Assistida) para "relacionamentos homoafetivos e pessoas solteiras". 
Resolução CFM N 2013/2013 ${ }^{348}$, publicada no D.O.U de 09 de maio de 2013.

Adota as normas éticas para a utilização das técnicas de reprodução assistida, anexas à presente resolução, como dispositivo deontológico a ser seguido pelos médicos e revoga a Resolução CFM n ${ }^{\circ}$ 1.857/2010.

[...] CONSIDERANDO que o pleno do Supremo Tribunal Federal, na sessão de julgamento de 5.5.2011, reconheceu e qualificou como entidade familiar a união estável homoafetiva (ADI 4.277 e ADPF 132);

\section{[...] II- PACIENTES DAS TÉCNICAS DE RA}

2 - É permitido o uso das técnicas de RA para relacionamentos homoafetivos e pessoas solteiras, respeitado o direito da objeção de consciência do médico.

Segunda consideração:

A coleta do material e sua utilização dependerão de anuência expressa dos interessados. A Resolução CFM no 2013/2013 é clara quanto à obrigatoriedade do consentimento informado a todos os pacientes submetidos às técnicas de reprodução assistida, inclusive aos doadores. Além disso, o documento de consentimento informado será expresso em formulário especial e estará completo com a concordância, por escrito, das pessoas submetidas às técnicas de reprodução assistida. ${ }^{349}$

Quanto à manifestação livre e consciente da vontade, esta é requisito de validade para todo e qualquer negócio jurídico.

O professor Antonio Junqueira de Azevedo ensina que: “A declaração da vontade, tomada primeiramente como um todo, deverá ser: resultante de um processo volitivo, querida com plena consciência da realidade, escolhida com liberdade e deliberada sem máfé." 350

\section{Terceira consideração:}

A manutenção do sigilo da identidade do doador é tema bastante controvertido, face ao direito à identidade genética do indivíduo que é fruto de fertilização heteróloga.

\footnotetext{
348 Resolução CFM $\mathrm{n}^{\mathrm{o}}$ 2013/2013, Princípios Gerais, 3.Disponível em: http://www.portalmedico.org.br/resolucao/CFM/2013 2013.pdf. Acesso em: 07 jun. 2012.

349 Resolução CFM n ${ }^{\circ}$ 2013/2013, Pacientes das Técnicas de RA 3.Disponível em: http://www.portalmedico.org.br/resolucao/CFM/2013 2013.pdf. Acesso em: 07 jun. 2012.

${ }^{350}$ AZEVEDO, Antônio Junqueira de. Negócio jurídico: existência, validade e eficácia. 4 ed. São Paulo: Saraiva, 2002, p. 43.
} 
Ensina o professor Jorge Shiguemitsu Fujita ${ }^{351}$ que:

"Cabe ao filho originário da técnica de reprodução assistida heteróloga o direito de conhecer o doador anônimo do sêmen ou a doadora anônima do óvulo, mediante ação investigatória de paternidade, ou de maternidade, em face do pai biológico ou da mãe biológica, sem que isso venha a importar na declaração do estado de filho natural, porquanto a relação paterno-filial, ou materno-filial, já resta fixada e reconhecida com o pai socioafetivo ou com a mãe socioafetiva".

Quarta consideração:

Caso de uma mulher que queira se utilizar das técnicas de reprodução artificial assistida, com intuito de formar uma família monoparental. Guilherme Calmon ${ }^{352}$ defende a inexistência de razão para se proibir o procedimento, em razão do reconhecimento constitucional da família monoparental, de acordo com o disposto no artigo $226, \S 4^{\circ}$, da Constituição Federal. Além disto, a lei brasileira permite a adoção de crianças por apenas um adotante, portanto, por analogia, deve-se estender este direito às mulheres que quiserem submeter-se às técnicas de reprodução artificial assistida.

Faz-se necessário, portanto, um tratamento legislativo a respeito do tema. Encontram-se, em fase de tramitação, alguns projetos de lei que oferecem normatização ao

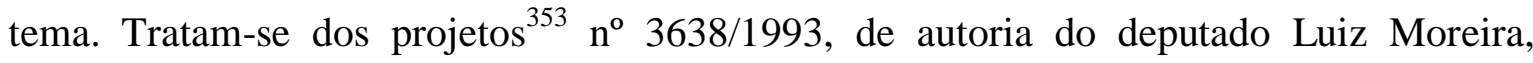
arquivado em 08/06/2007, PL n ${ }^{\circ}$ 54/2002, de autoria do Deputado Luiz Moreira, arquivado em 04/04/2007; PL 1184/2003, substitutivo ao $\mathrm{n}^{\mathrm{o}}$ 90/99, de autoria do senador Roberto Requião, ao qual foram apensados os PL 120/2003, PL 4686/2004, PL 2855/1997, PL 4665/2001, PL 1135/2003, PL 2061/2003, PL 4889/2005, PL 4664/2001, PL 6296/2002, PL 5624/2005, PL 3067/2008, PL 7701/2010, PL 3977/ 2012. Em 20/02/2013 o PL 4892/2012 foi também a este apensado.

Os Projetos de Leis acima referidos foram apensados e seguem sua tramitação, sem que o debate envolva as diversas camadas da sociedade e, em especial, os seus destinatários, isto é, pessoas que se encontram em situação vulnerável de esterilidade ou infertilidade diagnosticada.

\footnotetext{
${ }^{351}$ FUJITA, Jorge Shiguemitsu. Filiação. 2 ed. São Paulo: Atlas, 2011, p. 77.

${ }^{352}$ GAMA, Guilherme Calmon Nogueira da. A reprodução assistida heteróloga sob a ótica do Novo Código Civil. Revista Brasileira de Direito de Família. Porto Alegre: Síntese, IBDFAM, v.5, nº 19, ago./set., 2003, p.55.

353 Projeto de Leis. Disponíveis em: http://www.camara.gov.br. Acesso em 07/06/2012.
} 
Neste sentido, importante citarmos o Projeto de Lei 4892/2012, de autoria do Deputado Eleuses Paiva, o qual se originou do Anteprojeto do Estatuto da Reprodução Assistida de iniciativa da Prof ${ }^{a}$. Dra. Ana Cláudia Silva Scalquette, membro efetivo da Comissão de Biotecnologia da OAB/SP, sob a Presidência do Prof. Dr. Rui Geraldo Camargo Viana. Tal projeto de lei tem a finalidade de regular, no âmbito civil, administrativo e penal, as ações de aplicação e utilização das técnicas médicas de auxílio à reprodução humana, contendo $107 \operatorname{artigos}^{354}$.

Quinta consideração:

Sobre a gestação de substituição ou doação temporária do útero, a Resolução do CFM, No 2013/2013 prevê que:

As clínicas, centros ou serviços de reprodução humana podem usar técnicas de RA para criarem situação identificada como gestação de substituição, desde que exista um problema médico que impeça ou contraindique a gestação na doadora genética ou em caso de união homoafetiva.

1- As doadoras temporárias do útero devem pertencer à família de um dos parceiros num parentesco consanguíneo até o quarto grau (primeiro grau-mãe; segundo grau- irmã/avó; terceiro grau - tia; quarto grau - prima), em todos os casos respeitada a idade limite de até 50 anos.

2- A doação temporária do útero não poderá ter caráter lucrativo ou comercial

3- Contrato entre os pacientes (pais genéticos) e a doadora temporária do útero (que recebeu o embrião em seu útero e deu à luz), estabelecendo claramente a questão da filiação da criança.

Importante observar que a possibilidade de uso de útero alheio elimina a presunção mater sempre certa est (a mãe é sempre certa), a qual é determinada pela gravidez e pelo parto. Em consequência, também invalida a presunção pater est, isto é, que o pai é o marido da mãe.

Nota-se que a técnica de reprodução artificial muda a visão tradicional da família formada por um pai e uma mãe, tendo influências na questão da origem do homem.

Assim como a Resolução do CFM, No 2013/2013 assegura que a doação temporária do útero não poderá ter caráter lucrativo ou comercial, a Constituição Federal também veda a comercialização de qualquer órgão, tecido ou substância, de acordo com o

\footnotetext{
${ }^{354}$ Anteprojeto do Estatuto da Reprodução Assistida. Disponível em http://www.oabsp.org.br. Acesso em 07 jun. 2012.
} 
artigo 199, § $4^{\circ}$. Portanto é constitucionalmente proibido gestar o filho alheio, mediante pagamento.

No entanto, entendemos que as despesas com pré-natal e aquelas decorrentes do parto, assim como os medicamentos utilizados durante a gestação devam ser ressarcidos não caracterizando tal pagamento um caráter lucrativo ou comercial, mas um mero ressarcimento das despesas decorrentes da gestação de um filho.

De acordo com Maria Berenice Dias a gestação por substituição seria um negócio jurídico de comportamento, compreendendo para a mãe substituta obrigações de fazer e não fazer, culminando com a obrigação de dar, consistente na entrega do filho. Como uma criança não pode ser objeto de contrato, a avença seria nula, por ilicitude de seu objeto (art. 166, II, Código Civil). Também poderia configurar-se ilícito penal, que pune dar parto alheio como próprio e registrar como seu filho de outrem (art. 242 do Código Penal).

Nos casos de gravidez por substituição, mesmo que seja a mãe gestacional quem recebe a declaração de nascido vivo, importante é assegurar à mulher que desejou o filho e que não necessariamente é a mãe genética - o direito de constar no registro de nascimento como mãe. Tal direito tem de ser buscado em juízo, mesmo antes do nascimento para que, ao nascer, seja-lhe assegurado o registro com seu nome. ${ }^{355}$

Vejamos alguns casos emblemáticos:

- Em 17 de julho de 2012, a Justiça garantiu a um casal de Cuiabá o direito de registrar um filho biológico que estava sendo gerado em útero de substituição. A decisão foi tomada pela $4^{\mathrm{a}}$ Vara Especializada da Família e Sucessões da Comarca da Capital pelo juiz auxiliar Francisco Alexandre Ferreira Mendes Neto. A Ação Reivindicatória de Paternidade e Maternidade com Pedido de Antecipação de Tutela ganhou parecer favorável do Ministério Público e o juiz determinou ao Hospital a expedição da Declaração de Nascido Vivo da criança que está sendo gerada pela irmã de um dos requerentes em nome dos pais biológicos.

Na decisão, o juiz lembrou que o assunto é um tema polêmico, pois envolve questões éticas, morais e jurídicas e a situação fica mais complexa pela falta de legislação

\footnotetext{
${ }^{355}$ DIAS, Maria Berenice. Manual de Direito das Famílias. 6 ed. revista, atualizada e ampliada. São Paulo:
} RT, 2010, p. 365. 
específica a respeito. Destacou que a legislação em vigência não contém ressalva para a presunção de maternidade decorrente do parto (Artigos 1.603 e 1.608 ambos do Código Civil de 2002). ${ }^{356}$

- $\quad$ Em 26 de julho de 2012, Processo no 0016266-45.2012.8.26.0001, o Juiz de Direito Márcio Martins Bonilha Filho, da $2^{\mathrm{a}}$ Vara de Registros Públicos de São Paulo, deferiu o requerimento ordenando a averbação nos assentos de nascimento de gêmeos para constar na certidão de nascimento o nome de duas mães.

F. e W. ajuizaram ação declaratória de filiação, pleiteando a lavratura de assento de nascimento dos gêmeos, A. e B., frutos dos óvulos de F., fertilizados "in vitro" com o sêmen de um doador anônimo e, posteriormente, implantado no ventre de W., que se tornou gestante e genitora. As requerentes constituíram união estável e buscavam a proclamação judicial de que os gêmeos são filhos de ambas. Também justificam a necessidade de lavrar prontamente os assentos de nascimento, para inclusão dos gêmeos no plano de saúde. As autoras postularam a inclusão nos assentos de F., na condição de genitora, pois foram lavrados os assentos de nascimento dos gêmeos, figurando nos registros apenas a parturiente $\mathrm{W}$.

\section{$[\ldots]$}

$\mathrm{Na}$ sentença, o magistrado argumentou: "F., abstraídos os aspectos religiosos e morais, é tecnicamente, a mãe de sangue dos gêmeos, e reúne legitimidade para integrar os assentos de nascimento, na condição de genitora". O magistrado afirmou ainda: “...no caso em exame, recusar o registro da mãe biológica e blindar os termos para impedir que os gêmeos tenham duas mães, traduziria prorrogar o caso, que, certamente, seria sanado com adoção, o que não se concebe, conforme já sinalizado, na consideração de que $F$. é a que contribui geneticamente para a fertilização". ${ }^{357}$

- Em 17 de dezembro de 2013, o Brasil teve a primeira declaração de nascido vivo em nome de duas mães. A juíza Daniela Brandão Ferreira, da $1^{\text {a }}$ Vara de Família da comarca do Rio de Janeiro permitiu que a Declaração de Nascido Vivo (DNV) fosse emitida em nome das duas mães da criança, antes mesmo do registro civil. Foram apenas 15 dias de espera. A ação foi distribuída no dia 14 de novembro e já no dia 28 do mesmo mês, com o parecer favorável do Ministério Público, a Juíza deferiu os

\footnotetext{
${ }^{356}$ Pais podem registrar filho gerado em barriga de aluguel. Disponível em: http://www.conjur.com.br/2012ju-17/pais-podem-registrar-filho-gerado-barriga-aluguel-decide-tj-mt . Acesso em 18 jul. 2012.

357 Gêmeos têm Registro de Nascimento com Nomes de Duas Mães. Disponível em: http://www.tjsp.jus.br/Intranet/Noticia.aspx?Id=15036. Acesso em 27 jul. 2012.
} 
pedidos. As mães, que vivem há sete anos em união estável recorreram à fertilização in vitro e à doação anônima de esperma.

A Declaração de Nascido Vivo (DN) é um documento de identidade provisório dos recéns-nascidos, aceito em todo o território nacional. A Lei 12.662/2012 institui valor oficial ao documento. Com a lei é obrigatório que o número de identificação da DN conste na certidão de nascimento. ${ }^{358}$

Assim, embora sem legislação específica, o Poder Judiciário vem dotando de caracteres jurídicos uma realidade social que dia-a-dia torna-se mais presente em nossa sociedade. Os fundamentos jurídicos de tais decisões pesquisadas são: o princípio da dignidade da pessoa humana e da cidadania (artigo $1^{\circ}$, incisos III e II, CF/88), e dos direitos fundamentais à igualdade (artigo 5 $5^{\circ}$, caput e inciso, I, CF/88), liberdade, intimidade ( $\operatorname{artigo} 5^{\circ}, \mathrm{X}, \mathrm{CF} / 88$ ), proibição de discriminação (artigo $3^{\circ}$, inciso, IV, CF/88) e ao direito de se ter filhos e planejá-los de maneira responsável (artigos $5^{\circ}$, caput e 226, parágrafo $7^{\circ}$, da $\mathrm{CF}$ c/c artigo $2^{\circ}$ da Lei $\left.{ }^{\circ} 9.263 / 96\right)$.

- Homoparentalidade. Registro civil. Direito constitucionalmente assegurado. Tribunal TJPE, 14/03/2014. Juízo da $1^{\text {a }}$ Vara de Família e Registro Civil da Comarca do Recife, Processo de indicação de paternidade. $^{359}$.

M.O.N e M.T.S., amplamente qualificadas nos autos, ingressam com pedido de abertura da jurisdição administrativa deste Juízo e Registro Civil, postulando o assentamento civil, com a indicação da maternidade, das crianças D.T.O.N. e L.T.O.N., nascidos em 06/02/2014, concebidos a partir de inseminação artificial heteróloga, geradas no útero de M.T.S., com utilização de material genético dela própria e de sêmen doado por homem não identificado, para fazer constar o nome de ambas na qualidade de mães.

Os menores D.T.O.N. e L.T.O.N. estão sob a guarda das requerentes, as quais vivem em união homofetiva há mais de 10 (dez) anos, conforme faz prova a Escritura de Declaração de União Estável.

Pronunciando-se nestes autos, a representante do Ministério Público opinou favoravelmente ao pedido das requerentes, na esteira de seu parecer de fls., que abordou com preciosismo as questões marginais e

\footnotetext{
358 País tem primeira declaração de nascido vivo em nome de duas mães. Disponível em: http://ibdfam.org.br/noticias/5213+Pa\%C3\%ADs+tem+primeira+declara\%C3\%A7\%... Acesso em $18 \mathrm{dez}$. 2013.

359 Homoparentalidade. Registro Civil. Direito Constitucionalmente Assegurado. Disponível em: http://ibdfam.org.br/jurisprudencia/2336/Homparentalidade.\%20Registro\%20civil.\% ... Acesso em 14 mar. 2014.
} 
nucleares do presente feito, tornando despiciendas quaisquer delongas que frustrem a análise do ponto de maior pungência contido nesses autos - a luta pelo reconhecimento de direitos dos casais homoafetivos, notadamente, a homoparentalidade.

\section{$[\ldots]$}

Pelas frestas dos presentes autos se percebe a busca de duas cidadãs à fruição de direitos basilares, constitucionalmente albergados, e, à devida tutela estatal à nova formatação de entidade familiar e, em especial, de seus consectários, "in casu", o direito à homoparentalidade.

\section{$[\ldots]$}

Em suma, o que se busca, à mingua de legislação específica, é dotar de caracteres jurídicos uma realidade fenomênica, que, saliente-se não se restringe ao caso dos autos, pulverizando-se, dia a dia, na nossa teia social.

\section{$[\ldots]$}

Ao revés das incompreensíveis resistências sociais e institucionais, que se fundam em dogmatismos ultrapassados, me perfilo ao entendimento de que, qualquer dispositivo de lei que venha a constituir embaraço à plena fruição dos direitos fundamentais dos cidadãos, deva ser abolido do sistema jurídico vigente, por intermédio de um acurado procedimento hermenêutico, ou seja, através de uma interpretação pluralista e aberta dos dispositivos constitucionais que guardem correspondência com os princípios fundamentais do Estado Democrático de Direito.

Foi justamente isso que fizeram os Ministros do Supremo Tribunal Federal, em decisão proferida em 05 de maio de 2011 e que vem sendo apontada como indutora da catálise de entendimentos e avanços sobre a temática da homoafetividade em nosso país, tendo em vista sua natureza abrangente, justíssima e caudatária (dotada de eficácia contra todos e efeito vinculante - art. $102, \S 2^{\circ}, \mathrm{CF} / 88$ ).

Na dita decisão, prolatada na sede da Arguição de Descumprimento de Preceito Fundamental (ADPF) $\mathrm{n}^{\circ} 132$, convertida na Ação Direta de Inconstitucionalidade (ADI) $\mathrm{n}^{\circ}$ 4.277, os ministros daquela Corte, reconheceram, por unanimidade, a existência de mais um tipo de entidade familiar - a união de pessoas do mesmo sexo - e, via de consequência, reconheceram os mesmos direitos e deveres dos companheiros nas uniões estáveis àqueles que optam pela relação homofetiva.

Anote-se que a aludida decisão se reveste de um duplo efeito.

A um, para reconhecer a existência de mais um tipo de entidade familiar: o da união de pessoas do mesmo sexo.

A dois, e é esse o ponto de destaque, para estender os mesmos direitos e deveres dos companheiros nas uniões estáveis àqueles que optam pela relação homoafetiva. 
No cenário dos autos, vê-se uma entidade familiar, na qual as requerentes se reconhecem como homossexuais e almejam exercer, conjuntamente, a função de mães de duas crianças, fenômeno que vem sendo denominado pela doutrina moderna de homparentalidade, destacando-se, inclusive, que a Resolução CFM n 2013 de 09 de maio de 2013, que prescreve as normas éticas para a utilização das técnicas de reprodução assistida, dispõe expressamente que "É permitido o uso das técnicas de RA para relacionamentos homoafetivos e pessoas solteiras, respeitado o direito da objeção de consciência do médico".

\section{$[\ldots]$}

Volvendo-me às pesquisas e estudos oficiais sobre a homoparentalidade, que vêm sendo realizados ao redor do mundo há mais de 30 (trinta) anos, encampados por profissionais de múltiplas áreas do conhecimento, como a Psicologia, Antropologia, Psiquiatria, Pediatria, Serviço Social e do próprio Direito, temos que nenhum prejuízo à criança foi observado, sob o ponto de vista de sua saúde psíquica, estabilidade emocional, capacidade de adaptação ao meio, enfrentamento do estigma, desenvolvimento da identidade de gênero, orientação sexual, dentre outro aspectos.

\section{$[\ldots]$}

Refletindo no campo hipotético, sob o olhar daqueles que, de maneira radical, rechaçam a possibilidade da criação de menores por casais homoafetivos, alegando a eventual ocorrência de dano psíquico às crianças inseridas neste contexto familiar, tenho que, no meu sentir e valendo-me do senso comum, que tal prejuízo, revela-se, em verdade, àqueles submetidos a maus-tratos, abuso sexual, abandono ou alienação parental. O desejo de partilhar com uma criança o amor, o carinho e o cuidado, tem, ao revés, o condão de construir, de curar.

\section{$[\ldots]$}

Não proclamar tal pretensão corresponderia a uma usurpação principiológica da dignidade da pessoa humana e da cidadania (art. $1^{\circ}$, II e III, CF/88), e dos direitos fundamentais à igualdade (art. $5^{\circ}$, caput e I, $\mathrm{CF} / 88$ ), liberdade, intimidade (art. $5^{\circ}, \mathrm{X}, \mathrm{CF} / 88$ ), proibição de discriminação (art. $3^{\circ}, \mathrm{IV}, \mathrm{CF} / 88$ ), ao direito de se ter filhos e planejá-los de maneira responsável (arts. $5^{\circ}$, caput e 226, parágrafo $7^{\circ}$, da CF c/c art. $2^{\circ}$ da Lei $\left.n^{\circ} 9.263 / 96\right)$ e, por fim, da própria matriz estruturante do Estado Republicano de Direito: a democracia.

\section{$[\ldots]$}

Tenho que incoerente seria o Estado-Juiz legitimar, no plano jurídico, o exercício da conjugalidade homoafetiva e não reconhecer, por outro lado, o exercício da parentalidade. Revelar-se-ia discriminatório garantir o desempenho de ambos papéis, conjugal e parental, às famílias compostas de casais heteroafetivos em detrimento daquelas compostas por casais homoafetivos.

A presente decisão tem por escopo chancelar, juridicamente, o que no mundo dos fatos é irreversível, o exercício da coparentalidade homoafetiva, escolha já realizada pelas requerentes. 


\section{$[\ldots]$}

Conforme fortemente repisado no presente corpo sentencial, a aludida pretensão encontra fundamentação no Preâmbulo Constitucional; nos Princípios da República (art. $1^{\circ}$, II e III); nos Direitos e Garantias Fundamentais, quais sejam, a igualdade (art. $5^{\circ}$, caput, I), liberdade, intimidade (art. $\left.5^{\circ}, \mathrm{X}\right)$ e proibição da discriminação (art. $\left.3^{\circ}, \mathrm{IV}\right)$; no artigo 226, $\S \S 1^{\circ}, 3^{\circ}, 4^{\circ}, 5^{\circ}$ e $6^{\circ}$, todos, da Constituição da República; na Decisão do STF na ADI 4277 e na ADPF 132, acolhida como ADI e, por fim, na Resolução do Conselho de Direitos Humanos da Organização das Nações Unidas, destinada a promover a igualdade dos seres humanos, sem distinção de perfil sexual, em 17/06/2011, da qual o Brasil é signatário.

(TJPE, Sentença, Juiz de Direito Clicério Bezerra e Silva, j. 20/02/2014).

\subsection{Multiparentalidade}

Cada vez mais o Judiciário é chamado a analisar novos formatos de famílias, com dois pais ou duas mães, a chamada "multiparentalidade". São processos envolvendo uniões homoafetivas ou pais socioafetivos e pais biológicos.

Selecionamos alguns julgados interessantes:

- O Tribunal de Justiça do Estado de São Paulo, em 14 de agosto de 2012, reconheceu em decisão inédita a multiparentalidade para fazer constar no Registro de Nascimento de um rapaz de 19 anos o nome de sua madrasta sem excluir o nome da mãe falecida três dias após o parto.

Apelação Cível, Processo n. 0006422-26.2011.8.26.0286 ${ }^{360}$, Comarca de Itu (2 $2^{\mathrm{a}}$ Vara Cível). Relator Alcides Leopoldo e Silva Júnior. EMENTA: MATERNIDADE SOCIOAFETIVA. Preservação da Maternidade Biológica. Respeito à memória da mãe biológica, falecida em decorrência do parto, e de sua família - Enteado criado como filho desde dois anos de idade. Filiação socioafetiva que tem amparo no art. 1.593 do Código Civil e decorre da posse do estado de filho, fruto de longa e estável convivência, aliado ao afeto e considerações mútuos, e sua manifestação pública, de forma a não deixar dúvida, a quem não conhece, de que se trata de parentes - A formação da família moderna não-consanguínea tem sua base na afetividade e nos princípios da dignidade da pessoa humana e da solidariedade. Recurso provido.

\footnotetext{
360 Maternidade Socioafetiva. Disponível em: http://esaj.jus.br/apo/sg/search.do?conversationId=\&paginaConsulta=1\&localPesquisa.cdLoca . Acesso em 27 out. 2013.
} 
Trata-se de ação declaratória de maternidade socioafetiva c.c. retificação de assento de nascimento, julgada parcialmente procedente, apenas para incluir no assento de nascimento do requerente, o patronímico da coautora, porém, foi afastado o reconhecimento da filiação sociafetiva. Os autores apelaram pretendendo a reforma. A d. Procuradoria de Justiça opinou pelo provimento do recurso.

Esta é realmente uma decisão histórica. É a primeira vez que um Tribunal tem esse entendimento, ou seja, de manter em registro aquilo que ocorre na realidade. Decisão semelhante ocorreu no Estado de Rondônia na primeira instância.

- Outra decisão também inédita da Justiça brasileira, de 13 de novembro de 2014, permitiu que uma criança, nascida na Bahia fosse registrada com o nome de três mães. Além da mãe biológica, constará no documento do menino os nomes das mães adotivas, que têm um relacionamento homoafetivo. O garoto, que hoje tem três anos, ficará sob a guarda do casal, que entrou com pedido de adoção em 2012. A mãe biológica poderá visita-lo regularmente. $^{361}$

- TJRS, Apelação Cível No 70062692876, Oitava Câmara, Relator José Pedro de Oliveira Eckert, 12/02/2015.

Ementa: APELAÇÃO CÍVEL. DECLARATÓRIA DE
MULTIPARENTALIDADE. REGISTRO CIVIL. DUPLA
MATERNIDADE E PATERNIDADE. IMPOSSIBILIDADE JURÍDICA
DO PEDIDO. INOCORRENCIA. JULGAMENTO DESDE LOGO DO
MÉRITO. APLICAÇÃO ARTIGO 515, § $3^{\circ}$ DO CPC. Ausência de lei
para regência de novos - e cada vez mais correntes - fatos sociais
decorrentes das instituições familiares, não é indicador necessário de
impossibilidade jurídica do pedido. É que quando a lei for omissa, o juiz
decidirá o caso de acordo com a analogia, os costumes e os princípios
gerais de direito (artigo $4^{\circ}$ da Lei de Introdução ao Código Civil). Caso
em que se desconstitui a sentença que indeferiu a petição inicial por
impossibilidade jurídica do pedido e desde logo se enfrenta o mérito,
fulcro no artigo 515 , $3^{\circ}$ do CPC. Dito isso, a aplicação dos princípios da
"legalidade", "tipicidade" e "especialidade", que norteiam os "Registros
Públicos", com legislação originária pré-constitucional, deve ser
relativizada, naquilo que não se compatibiliza com os princípios
constitucionais vigentes, notadamente a promoção do bem de todos, sem
preconceitos de sexo ou qualquer outra forma de discriminação (artigo $3^{\circ}$,
IV da CF/88), bem como a proibição de designações discriminatórias
relativas à filiação (artigo 227 , § $6^{\circ}$, CF), "objetivos e princípios
fundamentais" decorrentes do princípio fundamental da dignidade da
pessoa humana. Da mesma forma, há que se julgar a pretensão da parte, a

361 Justiça dá a menino direito de ter três mães. Disponível em http://www.tjdft.jus.br/cidadaos/extrajudicial/extrajudicial-na-midia-justica-da-a-meni... Acesso em 13 nov. 2014. 
partir da interpretação sistemática conjunta com demais princípios infraconstitucionais, tal como a doutrina da proteção integral o do princípio do melhor interesse do menor, informadores do Estatuto da Criança e do Adolescente (Lei 8.069/90), bem como, e especialmente, em atenção do fenômeno da afetividade, como formador de relações familiares e objeto de proteção Estatal, não sendo o caráter biológico o critério exclusivo na formação de vínculo familiar. Caso em que no plano fático, é flagrante o ânimo de paternidade e maternidade, em conjunto, entre o casal formado pelas mães e do pai, em relação à menor, sendo de rigor o reconhecimento judicial da "multiparentalidade", com a publicidade decorrente do registro público de nascimento. ${ }^{362}$

Em apertada síntese, cuida-se de ação denominada de declaratória de multiparentalidade, ajuizada por duas mulheres e um homem, que requereram fosse deferido o registro civil da recém-nascida como filha dos três autores.

As mulheres viveram em união estável desde 2008 e se casaram em 2014. Alegaram que possuem um relacionamento de profunda amizade com o homem e, desde 2012, preparam-se, juntamente com as respectivas famílias, para ter um filho em conjunto. O trabalho de ambientação, para firmar uma cultura familiar comum, contou com a assessoria de psiquiatra e de terapeuta familiar. À médica especializada em reprodução humana coube a tarefa de orientar acerca da inseminação intra-uterina - o sêmen do homem foi colocado na cavidade uterina de uma delas, após um processo de estímulo da ovulação, bem como esclarecendo sobre os impedimentos legais para inseminação artificial no caso. Desta gravidez, em outubro de 2014, nasceu uma menina que, inicialmente, foi registrada apenas pelos pais biológicos. Agora, com a autorização do TJRS, o assento de nascimento será alterado, para inclusão dos três pais e respectivos avós. Para o relator da apelação, há que se julgar a pretensão da parte, a partir da interpretação sistemática conjunta com demais princípios infra-constitucionais, tal como da proteção integral, do princípio do melhor interesse da criança, previstos no Estatuto da Criança e do Adolescente (Lei 8.069/90), e especialmente em atenção ao fenômeno da afetividade como formador de relações familiares e objeto de proteção Estatal, não sendo o caráter biológico o critério exclusivo na formação dos vínculos familiares e portanto dos vínculos de filiação. ${ }^{363}$

\footnotetext{
362 TJRS, Apelação Cível $\quad \mathrm{N}^{\mathrm{o}}$ 70062692876. Disponível em: http://www.tjrs.jus.br/busca/search?btnG=busca\&entsp=a_politica-site \&wc $=200 \& w c \_m c=1 \& o e=\quad$ Acesso em 19 jul. 2015.

363 Menina será registrada por um pai e duas mães homossexuais. Disponível em: http://www.conjur.com.br/2015-fev-22/menino-registrado-pai-duas-maes-homossexua... Acesso em 12 mai. 2015.
} 
Em comentário a essa decisão, Maria Berenice Dias observa que o filho faz parte de dois núcleos familiares, um formado por suas mães, que são casadas e constituem uma família homoafetiva, sendo uma mãe biológica e a outra a socioafetiva, e outro formado pelo pai, fornecedor do material genético e que constitui com o filho uma família monoparental. $^{364}$

Da leitura desse julgado observa-se que os pais biológicos não são casados tampouco vivem em união estável, e, também, não tem um relacionamento conjugal, pois são apenas amigos. As duas mulheres são casadas entre si e tiveram uma filha por meio da reprodução artificial medicamente assistida heteróloga com doador de sêmen conhecido. Finalmente, assinaram um "Pacto de Filiação" e se comprometeram, reciprocamente, a observar uma série de requisitos quanto ao poder familiar, direito sucessório, guarda, visitação e alimentos em favor da filha comum. Além disso, amigos, familiares e profissionais que tomaram parte neste "projeto de família multiparental”, segundo os autos, foram unânimes em atestar o alto grau de compromisso dos autores com o bem-estar da criança no presente e no futuro.

É realmente bastante atípico tal projeto de família multiparental, e provoca certa insegurança jurídica. Só para reflexão: como decidir guarda, pensão alimentícia e sucessão na multiparetalidade? Como ficaria a sucessão em caso de falecimento deste menor, supondo que tivesse bens, com relação aos seis avós? Haveria necessidade de modificar vários aspectos do direito de família e das sucessões à medida que novos projetos multiparentais fossem sendo concebidos, criando uma enorme instabilidade jurídica.

Não se está aqui a condenar a multiparentalidade, que advém com o tempo e as circunstâncias da vida, da filiação biológica e socioafetiva ou da adoção e filiação socioafetiva. Porém, temos receio da multiparentalidade advinda de um projeto de filiação multiparental. Qual será o limite da multiparentalidade? Dois pais, duas mães, ou quanto mais melhor? Até aonde vai a imaginação humana?

\footnotetext{
${ }^{364}$ DIAS, Maria Berenice. Comentário da Decisão. Revista IBDFAM, Famílias e Sucessões. Mar/Abr.2015, p. 151
} 


\subsection{Reprodução medicamente assistida no direito estrangeiro}

\subsubsection{Portugal}

A Lei $\mathrm{n}^{\circ}$ 32, de 26 de julho, de 2006, regula as técnicas de Procriação Medicamente Assistida em Portugal (PMA). ${ }^{365}$

O texto da revista informa que houve uma lacuna de 20 anos entre o primeiro nascimento em Portugal de uma criança com recurso de fertilização in vitro e a Lei $\mathrm{n}^{\circ}$ 32/2006, que veio por fim a um longo vazio relativamente à utilização da técnica sem enquadramento normativo específico.

Existiam apenas algumas referências esparsas relacionadas com a PMA, nomeadamente, no $\mathrm{n}^{\circ} 3$ do Código Civil, que impede a impugnação de paternidade com fundamento em inseminação artificial ao cônjuge que nela consentiu, no Artigo 214, do Código Penal, que considera crime sexual, punível com pena de prisão de 1 a 8 anos, a prática de ato de procriação artificial em mulher sem o seu consentimento.

A nova Lei $n^{\circ} 32 / 2006$ disciplina, no artigo $2^{\circ}$, as técnicas de PMA: inseminação artificial, fertilização in vitro, injeção intra-citoplasmática de espermatozoides, transferência de embriões, gametas ou zigotos, diagnóstico genético, pré-implantação e outras técnicas laboratoriais de manipulação gamética ou embrionária equivalentes ou subsidiárias.

Como requisito dos beneficiários das técnicas de PMA, o artigo $6^{\circ}$ estabelece que a pessoa tenha o estado civil de casado, e não se encontre separado judicialmente de pessoas e bens ou separado de fato ou, as que sendo de sexo diferente, vivam em condições análogas às dos cônjuges, há pelo menos dois anos.

Da leitura do artigo $6^{\circ}$ vê-se claramente que em Portugal as técnicas de reprodução medicamente assistida não são permitidas aos casais do mesmo sexo, embora Portugal permita o casamento entre pessoas do mesmo sexo.

\footnotetext{
${ }^{365}$ Revista Portuguesa de Saúde Pública. Disponível em: http://www.cdi.ensp.unl.pt.. Acesso em 02 jun. 2012.
} 
Quanto ao consentimento estabelece que: são direitos dos beneficiários prestar o seu consentimento livre, esclarecido, de forma expressa e por escrito, perante o médico responsável após terem sido corretamente informados, também por escrito, de todos os benefícios e riscos conhecidos resultantes da utilização das técnicas de PMA, bem como suas implicações éticas, sociais e jurídicas. Em outro parágrafo do mesmo artigo: o consentimento dos beneficiários é livremente revogável por qualquer deles, até o início dos processos terapêuticos de PMA, conforme. Artigos 12,14 e 15.

Quanto à maternidade por substituição: são nulos os negócios jurídicos, gratuitos ou onerosos, de maternidade de substituição. Entende-se por maternidade de substituição qualquer situação em que a mulher se disponha a suportar uma gravidez por conta de outrem e a entregar a criança após o parto, renunciando aos poderes e deveres próprios da maternidade. A mulher que suportar uma gravidez de substituição de outrem é havida, para todos os efeitos legais, como a mãe da criança que vier a nascer, conforme Artigo $8^{\circ}$.

Vê-se que a gestação de substituição também não é permitida em Portugal.

Exclusão da paternidade do doador do sêmen: o doador do sêmen não pode ser havido como pai da criança que vier a nascer, não lhe cabendo quaisquer poderes ou deveres em relação a ela (conforme Artigo 21).

É proibida a compra ou venda de óvulos, sêmen ou embriões ou de qualquer material biológico decorrente da aplicação de técnicas de PMA (conforme Artigo 18).

Com relação ao sigilo, em Portugal, é garantido o sigilo de qualquer um dos participantes do procedimento da PMA, porem reserva-se ao concebido o direito de obter as informações de natureza genética que lhe digam respeito, excluindo a identificação do doador; informação sobre a existência de eventual impedimento quanto ao casamento, mantendo-se a confidencialidade acerca da identidade do doador, exceto se este expressamente o permitir. No entanto, sem prejuízo do disposto nos itens anteriores, podem ainda ser obtidas informações sobre a identidade do doador por razões relevantes reconhecidas por sentença judicial. ${ }^{366}$

${ }^{366}$ SCALQUETTE, Ana Cláudia S.. Estatuto da Reprodução Assistida. São Paulo: Saraiva. 2010, p. 249. 
No âmbito administrativo, a lei portuguesa cria um Conselho Nacional de Procriação Medicamente Assistida, ao qual compete pronunciar sobre questões éticas, sociais e legais da PMA.

A lei conta com 45 artigos todos com muitos detalhes. Enfocamos apenas alguns artigos que entendemos importantes, embora tantos outros não menos importantes tenham sido omitidos intencionalmente tendo em vista o curto espaço do trabalho.

Portanto, Portugal embora autorize o casamento homossexual, não permite a reprodução medicamente assistida aos pares homossexuais e tampouco a gestação de substituição.

\subsubsection{Espanha}

Sobre a legislação espanhola, a professora Ana Cláudia S. Scalquette ${ }^{367}$ ensina que a Espanha disciplinou a matéria da reprodução assistida pela Lei ${ }^{\circ} 14$, de 26 de maio de 2006. Veda a clonagem humana com fins reprodutivos. Somente será autorizada a transferência de no máximo três pré-embriões em cada mulher por ciclo reprodutivo. Prevê, ainda, a Lei no 14/2006 que a aceitação da aplicação das técnicas será explicitada em um formulário de consentimento informado, e serão dadas todas as garantias de confiabilidade e respeito à identidade dos doadores, dos usuários e das circunstâncias sobre a origem dos filhos nascidos. A lei espanhola prevê que as clínicas e hospitais somente poderão prestar os serviços reprodutivos se estiverem devidamente autorizados pela autoridade sanitária correspondente. Quanto à doação, está será gratuita, formal e confidencial, devendo constar de contrato escrito. Embora o sigilo seja garantido, os filhos têm direito de obter informações gerais sobre o doador, excluindo sua identidade. Porém, em circunstâncias excepcionais tal como perigo certo para a vida ou saúde do filho gerado, esta lei permite que se revele a identidade dos doadores, sempre que seja indispensável para se evitar o perigo ou para o fim legal proposto. Tal revelação não implicará, de forma alguma, a publicidade da identidade dos doadores e tampouco ensejará determinação legal

${ }^{367}$ SCALQUETTE, Ana Cláudia S.. Estatuto da Reprodução Assistida. São Paulo: Saraiva. 2010, p. 254 a 262. 
da filiação. Inovou a legislação espanhola ao determinar que poderá se submeter a qualquer uma das técnicas a mulher maior de 18 anos, capaz, independentemente de seu estado civil e orientação sexual. Veda qualquer inscrição no Registro Civil que possa indicar que o filho foi concebido por concepção artificial. A Lei n 14/2006 prevê, ainda, a inseminação "post mortem" desde que haja consentimento expresso do marido, em documento formal, para que sua mulher possa utilizar seu material nos doze meses que se seguirem ao seu falecimento, com os efeitos legais que derivam da filiação matrimonial. A legislação espanhola veda expressamente a gestação de substituição, mas prevê que em caso de ocorrência a filiação será determinada pelo parto, ficando resguardada a possibilidade de reclamação de paternidade ao pai biológico, conforme as regras gerais. Com relação à criopreservação, o sêmen poderá ser crioconservado em bancos de gametas autorizados, durante toda a vida do seu doador. Quanto aos pré-embriões excedentes, também poderão ser criopreservados até o momento em que os responsáveis médicos e especialistas independentes concluam que a receptora não reúne mais os requisitos clinicamente adequados para a prática da técnica de reprodução assistida. Os destinos de tais embriões crioconservados são: utilização pela própria mulher, a doação para fins reprodutivos, a doação para pesquisa ou o fim de sua conservação sem outra utilização, desde que finalizado o prazo legal para sua criopreservação. De acordo com esta lei, caberá à Comissão Nacional de Reprodução Humana Assistida, órgão colegiado de caráter permanente e consultivo, a direção e assessoramento sobre a utilização das técnicas de reprodução humana assistida. Finalizando, a professora Scalquette descreve as infrações nos campos administrativo, civil e penal, em matéria de reprodução humana assistida, classificando-as como leves, graves ou muito graves. Como muito graves cita o exemplo da prática de técnicas de reprodução assistida em centros que não tenham a devida autorização, a prática de seleção de sexo ou manipulação genética com fins não terapêuticos.

Assim, a Espanha permite a reprodução medicamente assistida aos pares homossexuais, mas não permite a gestação de substituição. Lembramos que a Espanha aceita o casamento homossexual. 


\subsubsection{Argentina}

Como visto anteriormente, o artigo 42, da Lei n. 26.618/2010 permitiu o casamento entre pessoas do mesmo sexo e modificou vários artigos do Código Civil argentino.

Artigo 42: "Todas as referências à instituição do matrimônio que contem nosso ordenamento jurídico se entendem aplicáveis tanto ao matrimonio constituído por duas (2) pessoas do mesmo sexo como ao matrimônio constituído por duas (2) pessoas de sexo diferente. Os integrantes das famílias cuja origem seja um matrimônio constituído por duas (2) pessoas do mesmo sexo, assim como um matrimônio constituído por pessoas de sexo diferente, terão os mesmos direitos e obrigações. Nenhuma norma do ordenamento jurídico argentino poderá ser interpretada nem aplicada no sentido de limitar, restringir, excluir ou suprimir o exercício ou gozo dos mesmos direitos e obrigações, tanto ao matrimônio constituído por pessoas do mesmo sexo como ao formado por duas (2) pessoas de sexo diferente". 368

Em 5 de junho de 2013 a Câmara dos Deputados da Argentina aprovou por esmagadora maioria a lei de fertilização assistida, Lei $\mathrm{n}^{\circ} 26.862$ que garante a casais hetero e homossexuais o acesso aos procedimentos e às técnicas de reprodução.

Pela leitura da Lei $\mathrm{n}^{\mathrm{o}} 26.682 / 2013^{369}$, observam-se alguns pontos principais:

- Acesso integral aos procedimentos e técnicas médico-assistenciais de reprodução medicamente assistida (artigo $1^{\circ}$ );

- O beneficiário desta lei é “toda pessoa maior de idade". Portanto o acesso é devido a todos os cidadãos argentinos, sejam eles casais heterossexuais ou homossexuais, ou ainda pessoas solteiras. (artigo $7^{\circ}$ );

- O procedimento é gratuito e está incluído no PMO (Programa Médico Obrigatório);

- A gestação de substituição não é regulamentada.

Assim, na Argentina, o casais homossexuais tem acesso à reprodução medicamente assistida, mas não há previsão sobre a gestação de substituição.

\footnotetext{
368 TORINO, Raffaele. La Tutela Della Vita Familiare Delle Coppie Omossexuali. Nel diritto comparato, europeo e italiano. Torino: G.Giappichelli Editore, 2012, p. 57-58.

${ }^{369}$ Ley 26.862. Disponível em http://bioetica.flacso.org.ar/textos/ley-26682,pdf. Acesso em 31 mai. 2015.
} 


\subsection{Adoção}

Com relação à adoção por casais homossexuais, no Brasil, não há legislação sobre o assunto, porém, o Estatuto da Criança e do Adolescente, e o atual Código Civil não proíbem tal adoção, quer unilateralmente, quer conjuntamente, sempre respeitados o melhor interesse da criança e do adolescente.

Para Maria Berenice Dias, o direito à adoção por casais homoafetivos tem fundamento de ordem constitucional. Não se pode excluir o direito à paternidade e à maternidade a gays, lésbicas, transexuais e travestis, sob pena de infringir-se o princípio da dignidade humana, que se sintetiza no princípio da igualdade e na vedação de tratamento discriminatório de qualquer ordem. O princípio do melhor interesse da criança deve servir de critério para a decisão do juiz, que deve verificar a situação real da criança e o que seria melhor para ela.

O Estatuto da Criança e do Adolescente não traz qualquer restrição quanto ao sexo, ao estado civil ou à orientação sexual do adotante, assegurando em seu artigo 42 que: "Podem adotar os maiores de dezoito anos, independentemente do estado civil". 370

Deve ser registrada também a possibilidade da paternidade ou maternidade socioafetiva, quando um dos pares desenvolve a socioafetividade em relação ao filho (a) do outro par, prevista no artigo 1.593 do Código Civil. ${ }^{371}$

Tendo em vista as novas modalidades de família que se formaram na pósmodernidade, ocorre intenso debate sobre a possibilidade de adoção por parte de casais formados por pessoas do mesmo sexo.

O que se questiona sempre é se as crianças criadas por casais homossexuais terão problemas futuros por serem filhos de um casal gay ou um casal de lésbicas?

O resultado mais recente sobre pesquisa neste sentido vem de um documento de 2007, contendo 72 páginas, Case No S147999, dirigido à Suprema Corte do Estado da Califórnia pelas três grandes associações de profissionais da saúde mental dos Estados

\footnotetext{
370 Dias, Maria Berenice. União Homoafetiva. O preconceito \& a justiça. 5 ed. revista, atualizada e ampliada. São Paulo: RT, 2011, p. 162-163.

${ }^{371}$ Artigo 1.593. O parentesco é natural ou civil, conforme resulte de consanguinidade ou de outra origem.
} 
Unidos, ou seja, American Psychological Association, a American Psychiatric Association e a National Association of Social Workers.

O conteúdo dos argumentos funda-se principalmente em que casais homossexuais formados por gays e lésbicas constroem relacionamentos estáveis com compromissos recíprocos os quais são equivalentes às relações de casais heterossexuais. Além disso, com relação à paternidade e à maternidade afirmam que não existe base científica para concluir que pais homossexuais sejam menos preparados ou capazes do que pais heterossexuais ou que as crianças de pais homossexuais sejam, de alguma maneira, menos saudáveis psicologicamente ou que tenham mais dificuldades de adaptação. ${ }^{372}$

O projeto de lei que deu origem à Lei 12.010, de 03 de agosto de 2009, conhecida como a "nova lei de adoção", tinha como objetivo adicionar ao diploma legal a adoção por casais homossexuais, porém, os líderes da maioria dos partidos disseram que só votariam se essa possibilidade fosse retirada. De acordo com o deputado João Matos (PMDB-SC), autor da emenda, a justificativa dos que se opuseram à adoção por casais do mesmo sexo é a de que a união civil de homossexuais ainda não é reconhecida formalmente. ${ }^{373}$

Com relação às decisões dos Tribunais, deve-se destacar a decisão do Tribunal de Justiça do Rio Grande do Sul, que em 05/04/2006, decidiu favoravelmente à adoção por casais do mesmo sexo.

APELAÇÃO CÍVEL SÉTIMA CÂMARA CÍVEL No 70013801592, Tribunal de Justiça do RS, Relator: Des. Luiz Felipe Brasil Santos. Julgado em 05/04/2006. ADOÇÃO. CASAL FORMADO POR DUAS PESSOAS DE MESMO SEXO. POSSIBILIDADE. Reconhecida como entidade familiar, merecedora da proteção estatal, a união formada por pessoas do mesmo sexo, com características de duração, publicidade, continuidade e intenção de constituir família, decorrência inafastável é a possibilidade de que seus componentes possam adotar. Os estudos especializados não apontam qualquer inconveniente em que crianças sejam adotadas por casais homossexuais, mais importando a qualidade do vínculo e do afeto que permeia o meio familiar em que serão inseridas e que as liga aos seus cuidadores. É hora de abandonar de vez preconceitos e atitudes hipócritas desprovidas de base científica, adotando-se uma postura de firme defesa da absoluta prioridade que constitucionalmente é assegurada aos direitos das crianças e dos adolescentes (art. 227 da Constituição Federal). Caso em que o laudo especializado comprova o saudável vínculo

372 Case $N^{\circ}$ S147999 In The Supreme Court of the State of California. Disponível em: http://www.courts.ca.gov/documents/Amer_Psychological_Assn_Amicus_Curiae_Brief. Pdf. Acesso em 01 jun. 2015.

373 Câmara aprova lei de adoção, mas casais homossexuais ficam fora do projeto. Disponível em: http://lfg.jusbrasil.com.br/noticias/97875/camara-aprova-lei-de-adocao-mas-casais-homossexuais-ficam-forado-projeto. Acesso em 13 jun. 2015. 
existente entre as crianças e as adotantes. NEGARAM PROVIMENTO. UNÂNIME. ${ }^{374}$

Em 27/04/2010, a $4^{\text {a }}$ Turma do Superior Tribunal de Justiça, de Relatoria do Ministro Luis Felipe Salomão, no REsp No 889.852-RS ${ }^{375}$, negou recurso do Ministério Público do Rio Grande do Sul e garantiu a adoção de duas crianças por um casal de mulheres.

DIREITO CIVIL. FAMÍLIA. ADOÇÃO DE MENORES POR CASAL HOMOSSEXUAL. SITUAÇÃO JÁ CONSOLIDADA. ESTABILIDADE DA FAMÍLIA. PRESENÇA DE FORTES VÍNCULOS AFETIVOS ENTRE OS MENORES E A REQUERENTE. IMPRESCINDIBILIDADE DA PREVALÊNCIA DOS INTERESSES DOS MENORES. RELATÓRIO DA ASSISTENTE SOCIAL FAVORÁVEL AO PEDIDO. REAIS VANTAGENS PARA OS ADOTANDOS. ARTIGOS $1^{\circ}$ DA LEI 12.010/09 E 43 DO ESTATUTO DA CRIANÇA E DO ADOLESCENTE. DEFERIMENTO DA MEDIDA.

Ainda o Superior Tribunal de Justiça, em 18 de dezembro de 2012, no julgamento do REsp No 1.281.093-SP (2011/0201685-2), pela terceira Turma, de relatoria da Ministra Nancy Andrighi, garantiu o pedido de adoção unilateral pela companheira da mãe biológica da adotanda, sendo a criança fruto de planejamento do casal, que já vivia em união estável e acordaram na inseminação artificial heteróloga por doador desconhecido.

CIVIL. PROCESSUAL CIVIL. RECURSO ESPECIAL. UNIÃO HOMOAFETIVA. PEDIDO DE ADOÇÃO UNILATERAL. POSSIBILIDADE. ANÁLISE SOBRE A EXISTÊNCIA DE VANTAGENS PARA A ADOTANDA ${ }^{376}$.

Em decisão de 13/02/2012, o Tribunal de Justiça de Minas Gerais, 8 a Câmara Cível, na Apelação Cível $\mathbf{N}^{\circ} \mathbf{1 . 0 4 7 . 0 8 0 4 7 2 5 4 - 6 / 0 0 1}^{377}$, de relatoria do Des. Bitencourt Marcondes entendeu pela adoção por casal do mesmo sexo.

EMENTA: APELAÇÃO CÍVEL. DESTITUIÇÃO DE PODER FAMILIAR. ABANDONO DA CRIANÇA PELA MÃE BIOLÓGICA.

374 Apelação Cível No 70013801592, Sétima Câmara Cível, Comarca de Bagé. Disponível em: http://jij.tjrs.jus.br/paginas/docs/jurisprudencia/Adocao_casal_formado_duas_pessoas...Acesso em 13 jun. 2015.

375 Recurso Especial $\quad N^{\circ} \quad 889.852-R S \quad$ (2006/0209137-4). Disponível em: http://ww2.stj.jus.br/processo/revista/documento/mediado/?componente=aTC\&sequencia=9823377\&num_re gistro=2. Acesso em 10 ago. 2010.

$376 \quad$ Recurso Especial $\mathrm{N}^{\circ} \quad 1.281 .093-\mathrm{SP} \quad(2011 / 0201685-2) . \quad$ Disponível em: https://ww2.stj.jus.br/processo/revista/documento/mediado=ATC\&sequencia=26262373\&num registro=201 102016852. Acesso em 04 fev. 2013.

${ }^{377}$ Apelação Cível. Destituição de poder familiar. Abandono da criança pela mãe biológica. Adoção por casal do mesmo sexo. Disponível em: http://www.ibdfam.org.br/?leisedecisoes\&jurisprudencia=1323. Acesso em 16 fev. 2012. 
ADOÇÃO POR CASAL DO MESMO SEXO QUE VIVE EM UNIÃO ESTÁVEL. MELHOR INTERESSE DA CRIANÇA. REGISTRO DE NASCIMENTO. RECURSO CONHECIDO E PROVIDO. I - A destituição do poder familiar é medida extrema, só devendo ser concretizada se comprovada a impossibilidade de permanência do menor com os pais. II - Sempre que se tratar de interesse relativo às crianças e adolescentes, o magistrado deve se ater ao interesse do menor, considerando, para tanto, primordialmente, o seu bem estar. III - O Supremo Tribunal Federal, ao julgar a Ação Direta de Inconstitucionalidade (ADI) 4277 e a Arguição de Descumprimento de Preceito Fundamental (ADPF) 132, reconheceu a existência de entidade familiar quando duas pessoas do mesmo sexo se unem, para constituição de uma família. IV - A vedação à discriminação impede qualquer intepretação proibitiva de que o casal homoafetivo, que vive em união estável, adote uma criança. V - Demonstrado nos autos que a genitora, com histórico de conduta agressiva e envolvimento com prostituição, abandonou a menor entregando-a aos cuidados das requerentes, e que a convivência com o casal homoafetivo atende, de forma inequívoca, o melhor interesse da criança, a destituição do poder familiar é medida que se impõe, nos termos do artigo 1.638, II e III, do Código Civil. VI- O pedido de adoção deve ser deferido em nome de ambas as autoras, sob pena de prejuízos à menor de ordem material (direito de herança, alimentos, dentre outros).

O Tribunal de Justiça do Estado de São Paulo, na Apelação Cível n 9000004-19. 2011.8.26.0576, de 27/02/2012, da Comarca de São José do Rio Preto ${ }^{378}$, Relator Silveira Paulilo, negou provimento ao recurso do Ministério Público que sustentou que o pedido de inscrição no cadastro de adoção por duas pessoas do mesmo sexo é "desinteressante e desvantajoso para a criança”, ressaltando ainda o perigo de que sofra preconceito.

Infância e Juventude. Inscrição no cadastro de adoção. Pretendente que admite manter relação homoafetiva. Deferimento com base em estudos psicossociais. Reconhecimento das uniões estáveis homoafetivas como entidades familiares. Ausência de circunstâncias incompatíveis com a natureza da adoção. Recurso improvido.

Trata-se de apelação interposta contra a $r$. sentença, cujo relatório se adota, que deferiu o pedido da requerente para inscrição no Cadastro de Pretendentes à Adoção. Apela o Ministério Público, sustentando que o pedido de inscrição no cadastro é "desinteressante e desvantajoso para a criança", ressaltando o perigo de que sofra preconceitos. Aduz, ainda, que a adoção por duas pessoas do mesmo sexo não encontra amparo legal. Arguiu ainda que, embora os pedidos tenham sido feitos individualmente, o objetivo da requerente e de sua convivente é de adoção conjunta, o que seria legalmente impossível, tendo em vista que o Estatuto da Criança e do Adolescente proíbe qualquer observação no registro de nascimento do adotado; e se for consignado o nome de dois pais ou de duas mães, automaticamente seria revelada a condição de adotado.

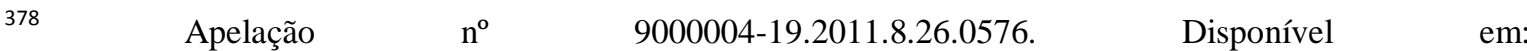
http://www.mpsp.mp.br/portal/page/portal/infanciahome_c/adocao/Jurisprudenciaa_adocao/cadas. Acesso
} em 25 mai. 2015. 


\section{$[\ldots]$}

No caso, o ponto controvertido cinge-se à possibilidade de adoção por casais homossexuais. A atenção do julgador, destarte, está voltada para o interesse da criança, em busca daquilo que revele e concretize sua maior proteção e segurança.

A Constituição da República no art. 226 estabelece a família como a base da sociedade, enquanto o direito à convivência familiar e comunitária encontra-se entre os direitos constantes do art. $4^{\circ}$, do Estatuto da Criança e do Adolescente.

\section{$[\ldots]$}

O Poder Judiciário é sensível às mudanças sociais e como bem destacado na r. sentença, "o Egrégio Supremo Tribunal (...) por unanimidade conheceu da Arguição de Descumprimento de Preceito Fundamental 132 como ação direta de inconstitucionalidade. Também por votação unânime, julgou procedente a ação, com eficácia "erga omnes" e efeito vinculante, para dar ao artigo 1.723, do Código Civil intepretação conforme à Constituição, para dele excluir qualquer significado que impeça o reconhecimento da união contínua, pública e duradoura entre pessoas do mesmo sexo como "entidade familiar", entendida esta como sinônimo perfeito de "família"."

Assim sendo, por decisão com efeitos vinculantes, o relacionamento homoafetivo se equipara à união estável para a aplicação do art. $42, \S 2^{\circ}$, do ECA.

Ademais, se a razão da existência do instituto da adoção é a concretização da garantia à convivência familiar (assegurada a todas as crianças e adolescentes, conforme preveem os arts. 227 , da CF e 19, do ECA) e se a união homoafetiva é uma entidade familiar, a adoção por um casal homossexual atende ao objetivo maior da adoção: assegurar a convivência familiar.

\section{$[\ldots]$}

Não há qualquer base empírica para se afirmar que as adoções por heterossexuais têm mais possiblidades de sucesso.

O risco de que a criança sofrerá preconceito é apenas mais uma das peças do quebra-cabeças das relações familiares. Mas os preconceitos existem na sociedade paulista em relação a outros cidadãos que também podem ser pretendentes a adoção: negros, índios, pobres, judeus, muçulmanos, analfabetos, nordestinos, nortistas, evangélicos, etc.

Logo, conceder adoções somente aos casais heterossexuais não é garantia de que os adotados não sofrerão qualquer preconceito.

$\mathrm{Na}$ nossa sociedade, o formato das famílias se alterou por demais e os adotados fazem parte dessa evolução. Assim sendo, cada família e suas crianças se ajustarão ao mundo de acordo com suas experiências e suas próprias características. Não há receita de felicidade. 
Pelo exposto, é que se nega provimento ao recurso.

Em 17/03/2015, a Ministra Cármen Lúcia, do STF (Supremo Tribunal Federal) negou recurso do Ministério Público do Paraná e manteve decisão que autorizou a adoção de crianças por um casal homoafetivo. Na decisão, a ministra argumentou que o conceito de família não pode ser restrito por se tratar de casais homoafetivos.

O caso chegou ao Supremo Tribunal Federal após o Ministério Público do Paraná querer limitar a adoção a uma criança com 12 anos ou mais, para que esta pudesse opinar sobre o pedido. No Supremo Tribunal Federal o Ministério Público alegou que a decisão contraria o artigo 226, parágrafo $3^{\circ}$ da Constituição Federal, que diz que para efeito da proteção do Estado, é reconhecida a união estável entre o homem e a mulher como entidade familiar.

Porém, para a Ministra Cármen Lúcia, o acórdão recorrido está em harmonia com a Jurisprudência do Supremo Tribunal Federal. Em sua decisão, a ministra citou o julgamento da Ação Direta de Inconstitucionalidade 4.277 e a Arguição de Descumprimento de Preceito Fundamental 132. Citou ainda trecho do voto do Ministro Carlos Ayres Britto, relator do julgamento ocorrido em maio de 2011, que disse:

Sem nenhuma ginástica mental ou alquimia interpretativa, dá para compreender que a nossa Magna Carta não emprestou ao substantivo "família" nenhum significado ortodoxo ou da própria técnica jurídica. Recolheu-o com o sentido coloquial praticamente aberto que sempre portou como realidade do mundo do ser".

RECURSO EXTRAORDINÁRIO 846.102. RECONHECIMENTO DE UNIÃO ESTÁVEL HOMOAFETIVA E RESPECTIVAS CONSEQUÊNCIAS JURÍDICAS. ADOÇÃO. AÇÃO DIRETA DE INCONSTITUCIONALIDADE N. 4277. ACÓRDÃO RECORRIDO HARMÔNICO COM A JURISPRUDÊNCIA DO SUPREMO TRIBUNAL FEDERAL RECURSO ESTRAODINÁRIO AO QUAL SE NEGA SEGUIMENTO. ${ }^{379}$

O direito a ter uma família é direito fundamental de todos. Assim, por meio do Poder Judiciário, o reconhecimento de dupla maternidade, dupla paternidade até da multiparentalidade, quer por adoções quer pelas técnicas de reprodução medicamente assistida vem ocorrendo, sempre vinculadas à necessidade de se verificar qual é a melhor solução a ser dada para a proteção dos direitos das crianças no caso concreto.

379 Cármen Lúcia reconhece adoção, sem restrição de idade, por casal gay. Disponível em: http://www.conjur.com.br/2015-mar-20/carmen-lucia-reconhece-adocao-restricao-ida... Acesso em 20 mar. 2015. 
Em sentido contrário, o Poder Legislativo defende o Projeto de Lei no 6583/2013, denominado Estatuto da Família o qual desconsidera que casais homossexuais constituem uma família e, portanto, não podem adotar. Há ainda, o Projeto de Lei no 4508 de 2008 que proíbe a adoção por homossexuais. Tal projeto foi apensado ao Projeto de Lei $\mathrm{n}^{\circ}$ 2285/2007 Estatuto das Famílias.

Porém, nem tudo são sombras, pois há a Proposta de Emenda Constitucional $n^{\circ}$ 110/2011, de autoria da senadora Marta Suplicy e outros que altera o art. $7^{\circ}$ da Constituição para dispor sobre licença-natalidade, licença após adoção e vedar discriminação de trabalhador em virtude de orientação sexual ou identidade de gênero.

Menos abrangente do que a PEC 110/2011 é a Lei no 12.873, de 24 de outubro de 2013, que garante salário-maternidade de quatro meses para homens e mulheres segurados do INSS que adotarem filho, independente da idade da criança. A Lei ${ }^{\circ}$ 12.873/2013 equipara homem e mulher no direito ao benefício em caso de adoção. A mesma regra vale para casais adotantes do mesmo sexo. ${ }^{380}$

\subsection{Conclusão}

Com relação à filiação homoparental, no Brasil, não há norma em nosso ordenamento jurídico que a proíba, porém não há legislação específica sobre o tema. As conquistas vêm de batalhas junto ao Poder Judiciário.

Em sentido contrário, alguns componentes do Poder Legislativo negam, por meio de Projetos de Leis, a existência da família formada por pessoas do mesmo sexo e por consequência não admitem a filiação homoparental.

Estudos científicos demonstram que casais homossexuais formados por gays e lésbicas constroem relacionamentos estáveis com compromissos recíprocos os quais são equivalentes às relações de casais heterossexuais. Além disso, com relação à paternidade $\mathrm{e}$ à maternidade afirmam que não existe base científica para concluir que pais homossexuais

\footnotetext{
${ }^{380}$ Lei garante salário maternidade para mulheres e homens adotantes e para casais do mesmo sexo. Disponível em http://www.ibdfam.org.br/noticias/5174/Lei+garante+sal\%C3\%A1rio+maternidade+p... Acesso em 29 out. 2013.
} 
sejam menos preparados ou capazes do que pais heterossexuais, ou que crianças de pais homossexuais sejam, de alguma maneira, menos saudáveis psicologicamente ou que tenham mais dificuldades de adaptação.

Os casais homossexuais podem ter seus filhos por meio da adoção, da reprodução medicamente assistida ou da filiação socioafetiva.

O projeto de Lei que deu origem à Lei 12.010, de 03 de agosto de 2009, conhecida como a "nova lei de adoção", tinha a previsão de adicionar ao diploma legal a adoção por casais homossexuais, porém os líderes da maioria dos partidos se opuseram porque a união civil de homossexuais ainda não era reconhecida formalmente.

Ocorre que, nos dias de hoje, o quadro se modificou. Em 05 de maio de 2011, após o julgamento das duas ações de Arguição de Descumprimento de Preceito Fundamento (ADPF 132/RJ) e Ação Direta de Inconstitucionalidade (ADI 4277/DF) o Supremo Tribunal Federal excluiu qualquer interpretação que impeça o reconhecimento da união contínua, pública e duradoura entre pessoas do mesmo sexo como "entidade familiar", entendida esta como sinônimo perfeito de família e com as mesmas regras e consequências da união estável heteroafetiva, não se podendo excluir do âmbito do direito de família os relacionamentos de pessoas do mesmo sexo.

No mesmo sentido tem se posicionado o Superior Tribunal de Justiça (STJ) com relação à adoção, conforme visto no Recurso Especial No 889.852-RS, de 27 de abril de 2010.

Com relação à reprodução medicamente assistida, não temos legislação a respeito e são seguidas as regras deontológicas estabelecidas pelas Resoluções do Conselho Federal de Medicina, sendo que a última Resolução do CFM 2013/2013 textualmente assegura que é permitido o uso de técnicas de RA para relacionamentos homoafetivos e pessoas solteiras respeitado o direito de objeção de consciência médica.

Vale lembrar também que os casais homossexuais podem se casar em todo o território nacional após a Resolução 175 do Conselho Nacional de Justiça, de 14 de maio de 2013.

A necessidade de se encontrar os limites, que se iniciam como éticos e que irão encontrar a sua formulação final no sistema jurídico é de fundamental importância. Por 
este motivo seria muito importante uma legislação sobre as técnicas de reprodução medicamente assistida, conforme já existem na Espanha, Portugal, Argentina e tantos outros países.

Neste sentido, preocupa-nos a multiparentalidade advinda de um "projeto de família pluriparental" utilizando-se das técnicas de reprodução medicamente assistida. Uma lei deixaria claros os limites e impediria que se gerassem crianças com tantos pais e mães quantos a imaginação humana pudesse alcançar.

Assim, embora sem legislação específica, o Poder Judiciário vem dotando de caracteres jurídicos uma realidade social que dia-a-dia torna-se mais presente em nossa sociedade. Os fundamentos jurídicos de tais decisões pesquisadas são: o princípio da dignidade da pessoa humana e da cidadania (artigo $1^{\circ}$, incisos III e II, CF/88), e dos direitos fundamentais à igualdade (artigo $5^{\circ}$, caput e inciso, I, CF/88), liberdade, intimidade (artigo $5^{\circ}, \mathrm{X}, \mathrm{CF} / 88$ ), proibição de discriminação (artigo $3^{\circ}$, inciso, IV, CF/88) e ao direito de se ter filhos e planejá-los de maneira responsável (artigos $5^{\circ}$, caput e 226, parágrafo $7^{\circ}$, da $\mathrm{CF}$ c/c artigo $2^{\circ}$ da Lei $\left.n^{\circ} 9.263 / 96\right)$. 


\section{ANÁLISE DOS PRINCIPAIS PROJETOS DE LEIS}

\subsection{Projeto de Lei $\mathbf{n}^{\circ} 1.151 / 1995^{381}$}

Um dos mais antigos e notórios projetos de lei sobre os pares homoafetivos é o Projeto de Lei 1.151/1995 da então Deputada Marta Suplicy, que disciplina a união civil entre pessoas do mesmo sexo, e o Substituto ao Projeto de Lei 1.151/1995, que disciplina a parceria civil registrada entre pessoas do mesmo sexo.

Em 31/05/2001 foi retirado de pauta e a última atualização data de 14/08/2007 por solicitação do deputado Celso Russomanno para a inclusão na ordem do dia do PL 1.151/1995, que disciplina a união civil entre pessoas do mesmo sexo.

Ensina o professor Álvaro Villaça Azevedo que este projeto objetiva disciplinar a "união civil entre pessoas do mesmo sexo", que se constituirá mediante registro de escritura pública, em Cartório do Registro Civil. Este projeto faz nascer dessa "parceria registrada" o estado civil de parceiro, o que não existe sequer na união estável. Quanto às economias, os parceiros poderão soma-las para a aquisição de bens, especialmente de sua moradia, sendo esta garantida como bem de família. Assim, também, o plano de saúde e seguro de grupo, feito por um, beneficiará o outro. Há algumas restrições, como, por exemplo, a impossibilidade de adoção de filho pelo casal de parceiros, mesmo que seja filho de um deles. ${ }^{382}$

Vê-se que tal projeto foi um embrião na tentativa de proteção aos casais homoafetivos. Porém, não se tratava de constituição de uma família, nem seria possível a adoção. Logo, a intenção era mais no sentido de proteger o patrimônio construído pelo casal, possibilitando a extinção contratual por morte ou por via judicial, litigiosa ou amigável.

\footnotetext{
$381 \quad$ PL 1151/1995 - Câmara dos Deputados. Disponível em: Www.camara.gov.br/proposicoesweb/fichadetramitacao?idProposicao... Acesso em 26 jul. 2015.

382 AZEVEDO, Álvaro Villaça. Uniões entre pessoas do mesmo sexo. Revista da Faculdade de Direito. Universidade de São Paulo. Vol. 94, 1999, p. 13.
} 
Embora a parceria civil não constituísse uma família a ela eram aplicados institutos do direito de família tal como o "bem de família" e os direitos sucessórios nos moldes da Lei n. 8.971/1994, relativa à união estável.

\subsection{Projeto de Lei $n^{0} 2.773 / 20000^{383}$}

Em agosto de 2005, a Comissão de Constituição e Justiça e Cidadania da Câmara dos Deputados aprovou o Projeto de Lei 2.773/2000, do deputado Alceste Almeida (PMDB-RR), que exclui a referência à pederastia no Código Penal Militar, em função de uma possível inconstitucionalidade do artigo 235, que discriminaria os homossexuais. $\mathrm{O}$ projeto mantém como crime militar quaisquer práticas sexuais no ambiente militar, sem qualquer referência à homossexualidade. O projeto está sendo analisado em conjunto com outro, o Projeto de Lei 6.871/2006, da deputada Laura Carneiro (PFL-RJ), que também exclui a referência à pederastia e à discriminação homossexual no texto da lei, porém permite o ato sexual no ambiente militar, desde que o ato seja consensual e praticado entre cônjuges ou unidos estavelmente em residência sujeita à administração militar.

A última ação legislativa ocorreu em 29/05/2014, em que o deputado Jean Wyllys (PSOL-RJ) requer inclusão na Ordem do Dia do Projeto de Lei $\mathrm{n}^{\circ} 2.773$, de 2000, que: “Altera a redação do art. 235, do Código Penal Militar, excluindo do texto o crime de pederastia".

\subsection{Projeto de Lei $n^{0} 580 / 2007^{384}$}

O Projeto de Lei $\mathrm{n}^{\circ}$ 580/2007, do falecido deputado Clodovil Hernandes (PTC/SP), altera a Lei $\mathrm{n}^{\mathrm{o}}$ 10.406, de 10 de janeiro de 2002 - Código Civil, para dispor sobre o contrato civil de união homoafetiva.

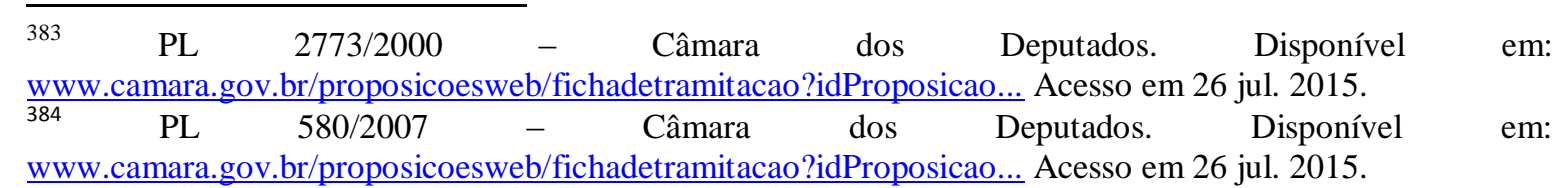


Capítulo XVIII-A, Do contrato de união homoafetiva

Art. 839-A. Duas pessoas do mesmo sexo poderão constituir união homoafetiva por meio de contrato em que disponham sobre suas relações patrimoniais.

Parágrafo único. É assegurado, no juízo cível, o segredo de justiça em processos relativos a cláusulas do contrato de união homoafetiva.

Art. $4^{\circ}$. Acrescente ao art. 1.790 da Lei 10.406 , de 10 de janeiro de 2002, o seguinte parágrafo:

Parágrafo único. As disposições desse artigo aplicam-se, no que couber, aos companheiros homossexuais.

As modificações do Código Civil deste projeto tem o fim específico de proteção patrimonial. Timidamente referem-se às regras de sucessão dos companheiros, porém de forma indefinida, utilizando-se da expressão "no que couber". Não se refere à união homoafetiva como entidade familiar.

A última atualização legislativa desse projeto de lei é de 20/02/2015, da Coordenação de Comissões Permanentes (CCP): encaminhada à republicação.

Em 02/04/2009 foi apensado ao PL $\mathrm{n}^{\circ} 580 / 2007$ o PL $\mathrm{n}^{\circ} 4.914 / 2009$ dos deputados José Genoíno (PT/SP), Manuela D’Ávila (PCdoB/RS) e Maria Helena (PSB/RR) e outros, que altera a Lei $\mathrm{n}^{\circ}$ 10.406, de 10 de janeiro de 2002 - Código Civil, para aplicar à união estável de pessoas do mesmo sexo os dispositivos do Código Civil referentes à união estável entre homem e mulher, com exceção do artigo que trata sobre a conversão em casamento.

Art. $1^{\circ}$ - Esta lei acrescenta disposições à Lei 10.406 , de 10 de janeiro de 2002 - Código Civil, relativas à união estável de pessoas do mesmo sexo.

Art. $2^{\circ}$ - Acrescenta o seguinte art. 1.727 A, à Lei no 10.406 , de 10 de janeiro de 2002, Código Civil.

Art. N 1.727 A - São aplicáveis os artigos anteriores do presente Título, com exceção do artigo 1.726, às relações entre pessoas do mesmo sexo, garantidos os direitos e deveres decorrentes.

Este PL nº 4.914/2009 admite o instituto da união estável para pessoas do mesmo sexo, com a aplicação dos artigos do Título III, da União Estável, com exceção do artigo 1.726 que prevê a conversão em casamento. 
Representa uma abertura no pensamento dos legisladores, mesmo antes do julgamento do Supremo Tribunal Federal com relação ao reconhecimento das uniões homoafetivas como entidade familiar com os mesmo efeitos da união estável heteroafetiva.

É admirável, pois admitem a união homoafetiva como entidade familiar e não mais como sociedade de fato. Deixa claro que não se pode converter a união homoafetiva em casamento, ao invés de usar a expressão vaga "no que couber". Nada fala sobre a homoparentalidade, logo esse projeto aceita que pares homossexuais unidos pela união homoafetiva possam adotar e se utilizarem das técnicas de reprodução medicamente assistida.

Em 07/05/2009, o PL 5.167/2009, dos deputados Capitão Assumção (PSB/ES) e Paes de Lira (PTC/SP), que altera o art. 1.521 da Lei 10.406, de 10 de janeiro de 2002, que institui o Código Civil, estabelecendo que nenhuma relação entre pessoas do mesmo sexo pode equiparar-se ao casamento ou a entidade familiar.

Art. $1^{\circ}$ Esta lei altera a redação do art. 1.521 da Lei $\mathrm{n}^{\circ} 10.406$, de 10 de janeiro de 2002, Código Civil.

Art. $2^{\circ} \mathrm{O}$ art. 1.521 da Lei ${ }^{\circ} 10.406$, de 10 de janeiro de 2002, Código Civil, passa a vigorar com a seguinte redação:

“Art. 1.521

Parágrafo único. Nos termos constitucionais, nenhuma relação entre pessoas do mesmo sexo pode equiparar-se ao casamento ou a entidade familiar.

Este projeto vai de encontro ao que decidiu o Supremo Tribunal Federal quanto ao reconhecimento das uniões homoafetivas como entidade familiar e também contra a decisão do Superior Tribunal de Justiça que permitiu o casamento entre duas pessoas do mesmo sexo.

A Justificativa do referido projeto é vastamente fundamentada em valores e princípios religiosos.

Em 08/08/2011 foi apensado ao PL 580/2007, o PL 1.865/2011, do deputado Salvador Zimbaldi (PDT/SP), que visa facilitar a conversão da união estável em casamento civil, não admitida nas situações de pessoas que realizaram troca de sexo por métodos cirúrgicos. 
Art. $1^{\circ}$ - Esta lei dispõe sobre a regulamentação da Entidade Familiar prevista pelo artigo 226, Parágrafo $3^{\circ}$, da Constituição Federal.

\section{[...]}

Art. $4^{\circ}$ - Em nenhuma hipótese será admitido casamento civil ou reconhecimento de União Civil de pessoas do mesmo sexo.

Parágrafo $1^{\circ}$ - Todas as Uniões Civis de pessoas do mesmo sexo registradas em Cartórios de Registro Civil no âmbito nacional, realizados espontaneamente pelo Cartório ou que tenham sido realizadas por determinação judicial, será imediatamente revogado (sic), e cessados os seus efeitos, após a publicação dessa Lei.

[...]

Art. $6^{\circ}$ - Fica proibida a adoção de crianças de qualquer idade por união de pessoas do mesmo sexo.

Numa linguagem desprovida de efeitos e conteúdos jurídicos e erros gramaticais, despreza a legislação existente da união estável e desqualifica as decisões do Supremo Tribunal Federal em relação à união homoafetiva e decisão do Superior Tribunal de Justiça com relação ao casamento.

Em 08/04/2013 foi apensado a este projeto de lei o Projeto de Lei $n^{\circ}$ 5.120/2013, de autoria dos deputados Jean Wyllys (PSOL/RJ) e Erika Kokay (PT/DF), que altera os arts. $551,1.514,1.517,1.535,1.541,1.565,1.567,1.598,1.642,1.723$ e 1.727 da Lei $n^{\circ}$ 10.406 de 10 de janeiro de 2002, para reconhecer o casamento civil e a união estável entre pessoas do mesmo sexo.

Resumidamente este projeto prevê para o reconhecimento do casamento civil e da união estável entre pessoas do mesmo sexo a substituição dos termos "marido e mulher" por "cônjuge" e "homem e mulher" por "pessoas". 


\subsection{Projeto de Lei $\mathbf{n}^{\circ}$ 2285/2007 - Estatuto das Famílias ${ }^{385}$}

O Projeto de Lei nominado Estatuto das Famílias - PL 2285/2007 visa revogar o livro de Direito de Família do Código Civil de 2002 a fim de criar um microssistema jurídico específico para as relações familiares, o qual prevê, em sua redação originária, a "união homoafetiva" como entidade familiar autônoma, sendo que em seu substitutivo, em acordo com a bancada evangélica do Congresso Nacional tal instituto foi retirado. ${ }^{386}$

Posteriormente, esse projeto foi apensado ao PL 674/2007, que estabelece o estado civil das pessoas em união estável como o de consorte e institui o divórcio de fato. Altera a Lei ${ }^{\circ} 10.406$, de 2002 e revoga as Leis $n^{\circ} 8.971$, de 1994 e $n^{\circ} 9.278$, de 1996. A última atualização desse projeto de lei data de 15/02/2011, em que foi indeferido o pedido de desarquivamento.

A Comissão de Seguridade Social e Família aprovou em 26/08/2009 o substituto do deputado José Linhares (PP/CE), eliminando todos os dispositivos que considerou contrários aos "valores judaico-cristãos da sociedade brasileira".

Linhares não apenas retirou do projeto a permissão para a união civil de pessoas do mesmo sexo como proibiu expressamente esse tipo de casamento, assim como proibiu expressamente a adoção por casal homossexual. Também substituiu todas as expressões "parceiro" contidas no projeto por "companheiro" e eliminou um artigo que considerava dever da sociedade e do Estado promover o respeito à diversidade de orientação sexual. ${ }^{387}$

Assim, o artigo 68 desse Estatuto que reconhecia como entidade familiar a união entre duas pessoas de mesmo sexo, que mantenham convivência pública, contínua, duradoura, com o objetivo de constituição de família foi totalmente suprimido.

O artigo 24, que tratava dos impedimentos ganhou o inciso VI onde se lê: Não podem casar: VI- as pessoas do mesmo sexo.

385 PL 2285/2007 - Câmara dos Deputados. Disponível em: Www.camara.gov.br/proposicoesweb/fichadetramitacao?idProposicao... Acesso em 26 jul. 2015.

386 VECCHIATTI, Paulo Roberto Iotti. Manual da Homoafetividade. Da possibilidade jurídica do casamento civil, da união estável e da adoção por casais homoafetivos. 2. ed. São Paulo: Gen, Método, 2013, p. 152 .

387 Câmara aprova projeto que cria Estatuto das Famílias. Disponível em: http://www.migalhas.com.br/Quentes/17,MI9186,41046-Camara+aprova+projeto+q... Acesso em 03 fev. 2014. 
O artigo 79, que tratava da adoção, recebeu em seu parágrafo único a proibição para os casais homossexuais. [...] sendo vedada a adoção por casal homossexual.

Quanto a tornar o Capítulo do Direito de Família matéria Estatutária, entendemos ser desnecessária tal mudança, pois o Código Civil é um todo uniforme, sendo que as normas da Parte Geral se espraiam para toda a Parte Especial formando um todo harmônico e indissociável.

\subsection{Projeto de Lei $n^{0} 612 / 2011^{388}$}

O Projeto de Lei do Senado No 612/2011 é de autoria da senadora Marta Suplicy e altera a redação do art. 1.723 da Lei $\mathrm{n}^{\circ}$ 10.406/02 (Código Civil) para reconhecer como entidade familiar a união estável entre duas pessoas, configurada na convivência pública, contínua e duradoura e estabelecida com o objetivo de constituição de família. Altera a redação do art. 1.726 da referida Lei para prever que a união estável poderá converter-se em casamento, mediante requerimento formulado pelos companheiros ao oficial do Registro Civil, no qual declarem que não têm impedimentos para casar e indiquem o regime de bens que passam a adotar, dispensada a celebração, produzindo efeitos a partir da data do registro do casamento.

O último andamento do projeto data de 05/03/2015 na Comissão de Constituição, Justiça e Cidadania. A matéria está pronta para a Pauta na Comissão, com voto do Senador Roberto Requião pela aprovação do Projeto.

\subsection{Projeto de Lei $\mathrm{n}^{\circ}$ 4.892/2012}

Este Projeto, de autoria do Deputado Eleuses Paiva (PSD/SP) institui o Estatuto da Reprodução Assistida, para regular a aplicação e utilização das técnicas de reprodução humana assistida e seus efeitos no âmbito das relações civis sociais.

\footnotetext{
388 PLS 612/2011 - Atividade Legislativa - Projetos e Matérias. Disponível em: www.senado.gov.br/atividade/materia/detalhes.asp?p_cad_mate... Acesso em 26 jul. 2015.
} 
Em 20/02/2013 foi apensado ao PL 1.184/2003, que define normas para realização de inseminação artificial e fertilização "in vitro"; proibindo a gestação de substituição e os experimentos de clonagem radical. Desde esta data o PL 1.184/2003 não teve mais andamento.

\subsection{Projeto de Lei $\mathbf{n}^{\circ}$ 470/2013 - Estatuto das Famílias ${ }^{389}$}

Em nova versão, é apresentado ao Senado o Projeto de Estatuto das Famílias PLS 470/2013 em 12 de novembro de 2013, de autoria da Senadora Lídice da Mata (PSBBA). O projeto procurou contemplar a proteção de todas as estruturas familiares presentes na sociedade moderna e contém regras de direito material e processual. "O objetivo é reunir, em um documento jurídico único, todas as normas relacionadas ao tema, permitindo tornar a Justiça mais ágil e conectada com a realidade familiar brasileira, assegura a senadora Lídice da Mata”.

Referido Projeto, conforme consta de seu art. 303, tem por objetivo revogar o Livro IV da Lei $\mathrm{n}^{\mathrm{o}}$ 10406/2002 (Código Civil, arts. 1.511 a 1.783), bem como as Leis $\mathrm{n}^{\mathrm{o}}$ 5.478/68 - Lei de Alimentos, Lei nº 6.515/77 - Lei do Divórcio, Lei de Investigação de Paternidade de filhos havidos fora do casamento, Lei $n^{\circ}$ 6.015/73 - Lei dos Registros Públicos (arts. 70 a 76), dentre outras e dispositivos do Código de Processo Civil.

De iniciativa do IBDFAM (Instituto Brasileiro de Direito de Família), de acordo com seu presidente, o advogado Rodrigo da Cunha Pereira, o Estatuto das Famílias vem atender à moderna linha do Direito Civil que é a criação de microssistemas, não cabendo, no mundo contemporâneo, um Código Civil que abranja tudo. Assim como existe o Estatuto da Criança e do Adolescente e o Estatuto do Idoso, agora temos um para tratar especificamente das famílias brasileiras.

Dentre os temas que podem ser considerados polêmicos no Congresso Nacional, está o reconhecimento das famílias homoafetivas. ${ }^{390}$

\footnotetext{
389 PLS 470/2013 - Atividade Legislativa - Projetos e Matérias. Disponível em: www.senado.gov.br/atividade/materia/detalhes.asp?p_cad_mate... Acesso em 26 jul. 2015.
} 
Quanto ao casamento, em seu artigo 20 assegura que:

O casamento é civil e produz efeitos a partir do momento em que os nubentes manifestem a vontade de estabelecer o vínculo conjugal e a autoridade celebrante os declara casados.

Vê-se que, ao utilizar o termo "nubentes", o referido Projeto de Lei acolhe o casamento entre pessoas do mesmo sexo, e se mantém de acordo com as decisões do Supremo Tribunal Federal e do Superior Tribunal de Justiça.

Com relação à união estável, o artigo 61 assevera que:

É reconhecida como entidade familiar a união estável entre duas pessoas, configurada na convivência pública, contínua, duradoura e estabelecida com o objetivo de constituição de família.

Parágrafo único. Independentemente de registro, a união estável constitui o estado civil de companheiro, o qual deve ser declarado em todos os atos da vida civil.

As novidades são que o termo "homem e mulher" foi substituído por "duas pessoas" e foi instituído o estado civil de companheiro independentemente de registro.

Em entrevista, ao site Consultor Jurídico, a Dra. Regina Beatriz Tavares da Silva teceu comentários sobre o Projeto de Lei n. 470/2013, apresentado ao Senado, em 12/11/2013. Transcrevemos algumas considerações:

Quer o PL n. 470/2013 institucionalizar a poligamia em nosso país, em seu art. 14 , caput e parágrafo único, que consta:

Art. 14. As pessoas integrantes da entidade familiar têm o dever recíproco de assistência, amparo material e moral, sendo obrigadas a concorrer, na proporção de suas condições financeiras e econômicas, para a manutenção da família.

Parágrafo único. A pessoa casada, ou que viva em união estável, e que constitua relacionamento familiar paralelo com outra pessoa, é responsável pelos mesmos deveres referidos neste artigo, e, se for o caso, por danos materiais e morais".

Assim, a amante ou o amante terão direito à pensão alimentícia e poderá requerer também a reparação dos danos morais e materiais que o amásio ou amásia lhe tenha causado. 391

Podemos observar que o Estatuto também confunde os conceitos de nulo e inexistente nos artigos 28 , III e $167, \S 2^{\circ}$, conforme se verifica:

390 Projeto de Estatuto das Famílias é apresentado no Senado.
http://ibdfam.org.br/noticias/5182/Projeto+de+Estatuto+das+Fam\%C3\%ADlias+C3 ... Acesso em 13 nov. 2013.

${ }^{391}$ SILVA. Regina Beatriz Tavares da. Estatuto das famílias retoma proposições desastrosas. Disponível em: http://www.conjur.com.br/2013-nov-19-regina-tavares-silva-familias-retom-. Acesso em 19 nov. 2013. 
Art. 28. É nulo o casamento:

\section{$[\ldots]$}

III- Quando revogada a procuração antes da celebração do casamento.

Art. 167. Um ou ambos os nubentes podem ser representados por procurador constituído mediante procuração outorgada por instrumento público, com poderes especiais e com o prazo de noventa dias.

\section{$[\ldots]$}

$\S 2^{\circ}$ Celebrado o casamento, sem que a revogação chegue ao conhecimento do mandatário, o ato é inexistente, devendo ser cancelado.

Em artigo publicado na Revista da ESA-Escola Superior de Advocacia, pode-se verificar que embora o Projeto de Lei do Senado $n^{\circ} 470 / 2013$ venha preencher o vazio legislativo quanto ao casamento e às uniões homoafetivas, este padece de muitas contradições e, em alguns aspectos, de inconstitucionalidade. ${ }^{392}$

\subsection{Projeto de Lei $N^{\circ}$ 6583/2013 - Estatuto da Família ${ }^{393}$}

O texto desse projeto apresentado pelo deputado Anderson Ferreira (PR-PE), em 16/10/2013, obriga o Poder Público a garantir as condições mínimas para a "sobrevivência" da família. A proposta define família como o núcleo formado a partir da união entre homem e mulher (repetimos o negrito do texto do Projeto de Lei), por meio de casamento, união estável ou comunidade formada pelos pais e seus descendentes.

O projeto também cria o Conselho da Família em âmbito federal, estadual, do Distrito Federal e municipal, formado por integrantes da sociedade e representantes do Poder Público. Um dos objetivos do conselho seria encaminhar ao Ministério Público e ao Judiciário qualquer informação que atente contra os direitos da família.

Ainda segundo a proposta, os processos judicias que constatem "risco à preservação e sobrevivência da entidade familiar" terão prioridade na tramitação. A última

392 MARTINS, Sandra Regina Carvalho (coordenadora); VIANA JÚNIOR, Edilberto Cavalcante; PUGLIESE, Ellen Cristina; CAFOLLA, Marcos; ARAUJO, Paula Cristina; BENTO, Yeda Peixinho. Breves considerações sobre o PLS n ${ }^{\circ}$ 470/2013, sob a ótica do Código Civil Vigente. Revista Científica Virtual, Formatos Familiares Contemporâneos, ESA-OAB/SP, ano V, no 18, 2014, p. 56-66. Disponível em: http://www.esaoabsp.edu.br/revista/edicao18/index.swf. Acesso em 28 out. 2014.

393 PL 6583/2013 $\quad-\quad$ Câmara dos Deputados. Disponível em: www.camara.gov.br/proposicoesweb/fichadetramitacao?idProposicao... Acesso em 26 jul. 2015. 
atualização do projeto é de 01/07/2015; em comparação com os demais este caminha a passos largos.

O professor José Fernando Simão comentando sobre o Projeto do Estatuto da Família, afirmou que:

Parece que o debate a ser travado no Congresso, ou o discurso a ser imposto pelos parlamentares, ignora que o tema já está amadurecido em termos jurídicos com as decisões do Supremo Tribunal Federal a respeito do conceito de família no Brasil.

[...]

Assim sendo, em linhas conclusivas, o que acontecerá se o Estatuto da Família for aprovado?

A resposta é simples: nascerá uma lei inconstitucional e que não produzirá nenhum efeito jurídico

É por isso que, paradoxalmente, penso que, talvez, seria melhor a aprovação deste odioso estatuto. E o raciocínio é feito de maneira utilitária. Com a aprovação, o Supremo Tribunal Federal declarará sua inconstitucionalidade com relação à categorização de família.

Então, o desiderato estará atingido. Será o fim do discurso eleitoreiro de alguns políticos, seja esse discurso decorrente de indisfarçável ignorância, seja esse discurso dolosamente engendrado para se angariar votos. ${ }^{394}$

Sob um manto de proteção à família, o Projeto acima esconde a homofobia e sua inconstitucionalidade.

Projeto idêntico foi aprovado em 20/06/2015 pela Câmara Legislativa do Distrito Federal, de autoria do deputado Rodrigo Delmasso (PTN), que institui o Estatuto da Família (PL 173/2015). Segundo o deputado, o Estatuto visa dar proteção à família. ${ }^{395}$

\subsection{Conclusão}

Desde 1995, época do Projeto de Lei 1.151/1995, da então deputada Marta Suplicy, que o país tenta aprovar alguma lei que assegure o mínimo de proteção aos homossexuais.

Não é pouco tempo, são exatos vinte anos em que o Poder Legislativo está em mora com relação à proteção dos direitos dessa minoria.

\footnotetext{
${ }^{394}$ SIMÃO, José Fernando. Se Estatuto da Família for aprovado, o STF o declarará inconstitucional. Disponível em http://www.profesorsimao.com.br/artigos/artigo.aspx?id=320. Acesso em 21 jul. 2015.

395 Para especialistas, Estatuto da Família aprovado no Distrito Federal é inconstitucional. Disponível em: http://ibdfam.org.br/noticias/5680/Para+especialistas\%2C+Estatuto+da+Fam\%C3\%A.... Acesso em 09 jun. 2015.
} 
Em matéria de direito de família, dentre os Projetos de Leis existentes, uma pequena parte defende os direitos e a proteção das famílias formadas por casais homossexuais, a outra, pelo contrário, tenta proibir e desqualificar tais uniões.

Num total desrespeito à matéria já julgada pelo Supremo Tribunal Federal, o Projeto de Lei $n^{\circ}$ 6.583/2013, Estatuto da Família segue adiante numa completa alienação.

Percebe-se que o Projeto de Lei $n^{0} 2.273 / 2000$, que exclui a referência à pederastia no Código Penal Militar é muito importante, na medida em que retira da nossa legislação o conceito de homossexualidade como crime.

Também o Projeto de Lei no 4.914/2009 apresenta uma evolução ao aplicar à união homoafetiva os dispositivos do Código Civil referentes à união estável entre homem e mulher. Porém, faz exceção à conversão da união homoafetiva em casamento.

Com relação ao Projeto de Lei n n $^{\circ} .120 / 2013$, que altera alguns artigos do Código Civil, para reconhecer o casamento civil e a união estável entre pessoas do mesmo sexo, mostra real avanço e compatibilidade com os julgamentos sobre a matéria pelo Supremo Tribunal Federal e pelo Superior Tribunal de Justiça.

Sobre o reconhecimento da união estável entre pessoas do mesmo sexo e a possiblidade de sua conversão em casamento é importante citar o Projeto de Lei do Senado nº 612/2011, da senadora Marta Suplicy que está caminhando positivamente.

Com relação a uma legislação sobre a Reprodução Medicamente Assistida, vê-se um total esquecimento do assunto. E, é, nesta seara, que podem ocorrer os maiores problemas, pois a única norma que existe é a Resolução 2013/2013 do Conselho Federal de Medicina. É certo que existem muitas questões com reflexos no âmbito civil, administrativo, penal, previdenciário, tributário e processual, as quais não podem ser solucionadas por uma resolução.

O Projeto de Lei $n^{\circ} 470 / 2013$, denominado Estatuto das Famílias, embora acolha o casamento e a união homoafetiva é grandioso demais e por isto apresenta contradições e inconstitucionalidade.

Sem a pretensão de resolver o assunto, mas, apenas apresentar uma visão pessoal sobre a legislação, apresentamos, no próximo capítulo, um pequeno esboço de projeto legislativo.

Quando do julgamento pelo Supremo Tribunal Federal, o Presidente, Ministro Cezar Peluso conclamou o Poder Legislativo para que assuma essa tarefa de regulamentar esta equiparação que até agora não se sentiu ainda propenso a exercer. 
Passados quatro anos, não há sinais de atuação dos legisladores sobre o assunto. Parafraseando o Ministro Luiz Fux: o silêncio legislativo pode ser interpretado como um juízo moral sobre o assunto. Na verdade, significa rejeição. 


\section{ESBOÇO DO PROJETO DE LEI}

Código Civil atual, Livro IV, Do Direito de Família, Título III, Da União Estável.

Com relação à união homoafetiva, propõe-se que sejam acrescentados dois artigos: o artigo 1.723-A e o artigo 1.727-A:

Artigo 1.723-A: Também é reconhecida como entidade familiar a união entre duas pessoas do mesmo sexo, denominada união homoafetiva, configurada na convivência pública, contínua e duradoura e estabelecida com o objetivo de constituição de família.

Artigo 1.727-A. São aplicáveis os artigos anteriores do presente Título às uniões homoafetivas, garantidos os direitos e deveres decorrentes.

Justificativa:

- Quanto ao nome união homoafetiva este foi escolhido tendo em vista o que consta da decisão do Supremo Tribunal Federal quando do julgamento das duas ações ADI 4277/DF e ADPF 132/RJ em 05/05/2011;

- Em homenagem ao professor Álvaro Villaça Azevedo que sempre defendeu ser a união homoafetiva um instituto jurídico autônomo dentro do contexto enunciativo do art. 226 da Constituição Federal;

- Possibilidade de os (as) companheiros (as) do mesmo sexo converterem sua união homoafetiva em casamento nos moldes do art. 1.726 do Código Civil, tendo em vista que a posição do Supremo Tribunal Federal foi de equiparação total entre a união estável e a união homoafetiva.

Com relação ao casamento homoafetivo:

Código Civil atual, Parte Especial, Livro I, Do Direito das Obrigações, Título VI, Das várias Espécies de Contrato.

Artigo 551.

Parágrafo único. Se os donatários, em tal caso, forem casados, subsistirá na totalidade a doação para o cônjuge sobrevivente.

Código Civil atual, Livro IV, Do Direito de Família, Título I, Do Direito Pessoal, Subtítulo I, Do Casamento. 
Artigo 1.514. O casamento se realiza no momento em que duas pessoas manifestam, perante o juiz, a sua vontade de estabelecer vínculo conjugal, e o juiz as declara casadas.

Artigo 1.517. As pessoas com 16 (dezesseis) anos podem casar, exigindo-se autorização de ambos os pais, ou de seus representantes legais, enquanto não atingida a maioridade civil.

Artigo $1.535 \ldots . . .$. nestes termos:

"De acordo com a vontade que ambos acabais de afirmar, de vos receberdes, por cônjuges, eu, em nome da lei, vos declaro casados (as)."

Artigo $1.541 \ldots .$.

$[\ldots]$

III - que, em sua presença, declararam os contraentes, livre e espontaneamente, receber-se por cônjuges.

Artigo 1.565. Pelo casamento, os cônjuges assumem mutuamente a condição de consortes, companheiros (as) e responsáveis pelos encargos da família.

Artigo 1.567. A direção da sociedade conjugal será exercida, em colaboração, pelos cônjuges, sempre no interesse do casal e dos filhos.

Subtítulo II, Das Relações de Parentesco.

Artigo 1.598. Relativamente a relações entre pessoas de sexos diferentes, salvo prova em contrário, se, antes de decorrido o prazo previsto no inciso II do art. 1.523, a mulher contrair novas núpcias e lhe nascer algum filho, este se presume do primeiro cônjuge, se nascido dentro dos trezentos dias a contar da data do falecimento deste e, do segundo, se o nascimento ocorrer após esse período e já decorrido o prazo a que se refere o inciso I do art. 1.597.

Título II, Do Direito Patrimonial, Subtítulo I, Do Regime de bens entre os cônjuges.

Artigo 1.642. Qualquer que seja o regime de bens, quaisquer dos cônjuges podem livremente: 
Justificativa:

- Adoção do casamento sexualmente neutro ou igualitário;

- O fundamento do casamento direto é o julgamento do Superior Tribunal de Justiça no REsp $n^{\circ}$ 1.183.378-RS, que embora não tenha efeito vinculante e eficácia erga omnes, autorizou o casamento entre duas lésbicas, com fundamento na decisão do Supremo Tribunal Federal sobre as uniões homoafetivas;

- Conforme consta do acórdão do REsp n ${ }^{\circ}$ 1.183.378-RS: “O Superior Tribunal de Justiça, cumprindo sua missão de uniformizar o direito infraconstitucional, não pode conferir à lei uma interpretação que não seja constitucionalmente aceita".

- Ainda de acordo com o acórdão: "Se é verdade que o casamento civil é a forma pela qual o Estado melhor protege a família, e sendo múltiplos os "arranjos" familiares reconhecidos pela Carta Magna, não há de ser negada essa via a nenhuma família que por ela optar, independentemente de orientação sexual dos partícipes, uma vez que as famílias constituídas por pares homoafetivos possuem os mesmos núcleos axiológicos daquelas constituídas por casais heteroafetivos, quais sejam, a dignidade das pessoas de seus membros e o afeto". 


\section{CONCLUSÃO}

1) A aceitação dos relacionamentos entre pessoas do mesmo sexo teve ciclos ao longo da história da humanidade, experimentando diversos altos e baixos. De comportamento absolutamente natural, passou a ser pecado, doença e até mesmo crime. É, até os dias de hoje, um assunto que provoca fortes debates;

2) $\mathrm{O}$ homoerotismo dentro do mundo grego tinha algumas características preponderantes. A paiderastia, amor por rapazes, se dava entre um homem mais velho, o erastes ou amante, e o eromenos, ou amado. A função do erastes era servir como modelo de coragem, sabedoria e virtude cívica para o eromenos, ou amado, jovem cuja atração se baseava na beleza física, no fato de ter um futuro moral, intelectual e militar promissor.

3) Com relação às uniões entre pessoas do mesmo sexo, parece que a atitude dos romanos foi mais ambígua do que a dos gregos. É certo que os romanos expressavam o interesse sexual tanto por homens quanto por mulheres, mas os relacionamentos entre homens não tinham o mesmo valor cultural presente na cultura grega. No período Republicano, tais relações eram vistas como relações de dominação, havendo uma correlação entre a conquista militar e a dominação sexual.

4) Embora historiadores afirmem a existência de casamento homossexual no período Republicano em Roma, as pesquisas demonstraram que, por enquanto, este fato não tem qualquer embasamento em fontes jurídicas. Os romanos tiveram sempre a convicção de que o matrimônio deveria ter como pressuposto a existência de pessoas de sexos diversos;

5) Com o advento do Cristianismo, a influência greco-romana se dissipou e o mito Sodoma e Gomorra ganhou espaço transformando a homossexualidade em pecado;

6) A sacralização da união heterossexual aconteceu na Idade Média, e o casamento foi transformado em sacramento. $\mathrm{O}$ ato sexual só era permitido dentro do casamento e para procriação, caso contrário seria pecado;

7) A partir dos séculos XIX e XX, pode-se dizer que a sociedade deixou de ser menos intolerante em relação à homossexualidade. Mas, infelizmente, não se impediu que milhares de homossexuais fossem assassinados nos campos de concentração nazistas;

8) Em 1969, os tumultos de Stonewall, marcados por diversos conflitos entre a polícia estadunidense e homossexuais, tiveram grande destaque na mídia. Neste contexto, foi 
cunhada a expressão "gay", para designar uma atitude de auto-estima e ativismo diante do preconceito e da discriminação;

9) Os conceitos sobre a homossexualidade que se formaram ao longo da história homossexualidade como pecado, como crime e como doença - embora desmistificados pelas mudanças sociais e pesquisas científicas, ainda estão presentes na sociedade e contribuem para a formação do preconceito e da intolerância contra os homossexuais;

10) Os dogmas das religiões devem ser respeitados, assim como devem ser respeitados todos os seres humanos na sua dignidade. A intolerância, o ódio, a discriminação não devem fazer parte de qualquer religião;

11) Nosso Estado é laico e o casamento é civil e, neste caso, também deve ser respeitada a laicidade do Estado e o motivo pecado jamais poderá ser utilizado como justificativa para não se aceitar o casamento entre pessoas do mesmo sexo;

12) No Brasil, embora a homossexualidade não seja considerada crime, ainda possui resquícios no Código Penal Militar (CPM) em seu artigo 235. Com o objetivo de sanar este problema, há vários projetos de leis e uma ação de Arguição de Descumprimento de Preceito Fundamental (ADPF-291);

13) Hoje, o conceito de homossexualidade como doença está totalmente superado pela comunidade científica, e orientação sexual, por si só, não é considerada um transtorno. Portanto, não se deve mais falar em homossexualismo, que designa doença, mas em homossexualidade, que significa um modo de ser;

14) Estes pré-conceitos trazidos, através dos séculos, pelas gerações, cristalizam o preconceito em cada um de nós. Tal mudança levará tempo, e o papel do Direito é a defesa de "uma sociedade fraterna, pluralista e sem preconceitos", como bem está escrito no Preâmbulo de nossa Constituição da República Federativa do Brasil;

15) Quanto à pesquisa sobre o casamento homossexual em outros países, verificamos que tanto a imprensa estrangeira, quanto a imprensa nacional, quando se referem ao casamento homossexual chamam-no de "casamento gay". Esta forma não é adequada, porque o casamento entre pares do mesmo sexo envolve o casamento entre dois homens (gays) ou entre duas mulheres (lésbicas). Portanto, o nome mais adequado é casamento homossexual (entre duas pessoas do mesmo sexo), ou, casamento homoafetivo;

16) A mudança de paradigma vem ocorrendo muito rapidamente pois, muitos países que hoje permitem o casamento homossexual, até cerca de vinte ou trinta anos atrás, 
criminalizavam os atos homossexuais. Podemos citar como exemplo: Irlanda, Nova Zelândia e Escócia;

17) No início de nossa pesquisa, em 2012, tínhamos apenas onze países no mundo que permitiam o casamento homossexual: Holanda, Bélgica, Espanha, Canadá, África do Sul, Noruega, Suécia, Portugal, Islândia, Argentina e Dinamarca. Hoje, são em número de dezoito, pois novos países legalizaram o casamento homossexual tais como: Uruguai, Nova Zelândia, França, Reino Unido (Inglaterra, País de Gales, Escócia, excluindo-se a Irlanda do Norte), Luxemburgo, Irlanda e Estados Unidos.

18) O país que mais nos causou espanto foi os Estados Unidos, onde atualmente, todos os cinquenta Estados permitem o casamento entre pessoas do mesmo sexo. Lembrando que apenas treze proibiam o casamento homossexual até junho de 2015, sendo eles: Kentucky, Michigan, Ohio, Tennessee, Texas, Lusiana, Arkansas, Georgia, Mississipi, Missouri, North Dakota, South Dakota e Nebrasca;

19) Com relação à pesquisa sobre os países que autorizam o casamento homossexual, verificamos algumas diferenças. A primeira diferença se refere à iniciativa da proposta de legalização do casamento homossexual. Em alguns países a iniciativa foi do Poder Executivo tal como na Espanha, Uruguai, Nova Zelândia e França; outras do Poder Judiciário tal como Canadá, África do Sul, Portugal e Argentina, outras do Poder Legislativo tal como Holanda, Bélgica, Noruega, Islândia, Dinamarca, Inglaterra, País de Gales Escócia, e Luxemburgo e outros ainda por meio de referendo popular, como foi o caso recente da Irlanda.;

20) Sobre os efeitos do casamento homossexual em relação aos filhos, alguns países admitem a presunção de paternidade e outros não; uns permitem a reprodução medicamente assistida e gestação de substituição, outros só admitem a adoção e outros ainda, como Portugal, não permitem sequer a adoção;

21) O fundamento sobre a aceitação do casamento homossexual nos vários países pesquisados foi, de maneira geral: que o matrimônio é um direito constitucional da pessoa; que a homossexualidade é uma característica profundamente pessoal, imutável ou mutável somente a custos pessoais inaceitáveis; atendimento ao princípio constitucional da igualdade; que a discriminação baseada na orientação sexual viola a dignidade humana; que há vedação constitucional à discriminação com relação a sexo, raça, religião e orientação sexual; que não se deve cogitar de ausência normativa, mas de simples omissão, 
não vedando a lei o casamento entre pessoas do mesmo sexo; mesmos direitos com o mesmo nome, ou seja, casamento igualitário, ou sexualmente neutro.

22) Outro fato importante para o direito foi que a Teoria do Casamento Inexistente, prevista explicitamente nos ordenamentos jurídicos de Portugal e da Argentina restou modificada pela alteração das respectivas legislações. Logo a diversidade de sexo não é mais causa de inexistência do casamento nestes dois países.

23) Percebe-se, que à medida que a sociedade se modificava também a família e o direito de família se modificavam.

24) Assim, todo um modo de ver o direito emergiu da Constituição Federal de 1988, uma verdadeira Carta de Princípios que impôs eficácia a todas as suas normas definidoras de direitos e de garantias fundamentais, de acordo com seu art. $5^{\circ}, \S 1^{\circ}$.

25) Aplicam-se ao direito de família os princípios constitucionais da dignidade da pessoa humana (art. $1^{\circ}$, III), o princípio e objetivo da proteção da sociedade, sem preconceitos de origem, raça, sexo, cor, idade e quaisquer outras formas de discriminação (art. $\left.3^{\circ}, \mathrm{IV}\right)$. Além disso, o art. $5^{\circ}, \mathrm{X}$ consagra o direito à intimidade. Portanto, como aspectos do exercício desse direito, tem-se a orientação e a prática sexual livres de discriminações.

26) Em nossos estudos verificamos que o princípio constitucional da igualdade dirigese também ao legislador, vedando-lhe que edite normas as quais incitem a desigualdade;

27) Em 05 de maio de 2011, o Supremo Tribunal Federal, em votação unânime, ao julgar a $\mathrm{ADI} \mathrm{n}^{\circ}$ 4277/DF e a $\mathrm{ADPF} \mathrm{n}^{\circ}$ 132/RJ reconheceu a união homoafetiva como entidade familiar. Ao interpretar o art. 1.723 do Código Civil conforme a Constituição Federal garantiu aos parceiros homossexuais os mesmos direitos e deveres da união estável, entendida a união homoafetiva como sinônimo perfeito de família;

28) De acordo com o voto do Ministro Ayres Brito no julgamento das duas ações ADI 4277/DF e ADPF 132/RJ, a terminologia “entidade familiar” não significa algo diferente de 'família", pois não há hierarquia ou diferença de qualidade jurídica entre as duas formas de constituição de um novo núcleo doméstico;

29) Ainda com relação ao voto do Ministro Ayres Brito: tanto no casamento quanto na união estável nenhuma referência é feita à proibição, ou à possibilidade de protagonização por pessoas do mesmo sexo. Inteligência que se robustece com a proposição de que não se proíbe nada a ninguém senão em face de um direito ou de proteção de um interesse de outrem; 
30) Quanto à adoção, a Constituição Federal não abre distinção entre adotante "homo ou "heteroafetivo";

31) Com relação ao voto do Ministro Luiz Fux na ADI 4277/DF e ADPF 132/RJ: não há qualquer inconstitucionalidade ou ilegalidade no estabelecimento de uniões homoafetivas. Não existe, no direito brasileiro, vedação às uniões homoafetivas, haja vista, sobretudo, a reserva de lei instituída pelo art. 5º inciso II, da Constituição de 1988 para a vedação de quaisquer condutas aos indivíduos;

32) Ainda sobre o voto do Ministro Luiz Fux: "o silêncio legislativo sobre as uniões homoafetivas nada mais é do que um juízo moral sobre a realização individual pela expressão de sua orientação sexual. Na verdade, significa rejeição";

33) Ministro Luiz Fux: a questão do reconhecimento das uniões homoafetivas também toca o tema da segurança jurídica;

34) Ministro Luiz Fux: não se há de fazer objeção de que o art. 226 , $\S 3^{\circ}$ da CF constituirá obstáculo à equiparação das uniões homoafetivas às uniões estáveis heterossexuais, por força da previsão literal "entre homem e mulher". A norma é de inclusão. Seria perverso conferir à norma de cunho indiscutivelmente emancipatório intepretação restritiva. A mesma lógica há de se estender ao art. 1.723 do Código Civil.

35) Ministra Cármen Lucia: "O Direito existe para a vida e não a vida para o Direito; contra todas as formas de preconceito há o Direito Constitucional”.

36) Ministro Ricardo Lewandowiski: “ união entre pessoas do mesmo sexo é um quarto gênero de entidade familiar não previsto no rol do art. 226 da Carta Magna";

37) Ministro Ricardo Lewandowiski: "Porém, o rol do art. 226 da CF não é taxativo, mas meramente exemplificativo, dada a natureza aberta das normas constitucionais";

38) Ministro Ricardo Lewandowiski: "o que se pretende, ao empregar o instrumento metodológico da integração, não é, à evidência, substituir a vontade do constituinte por outra arbitrariamente escolhida, mas apenas, tendo em conta a existência de um vácuo normativo, procurar reger uma realidade social superveniente a essa vontade, ainda que de forma provisória, ou seja, até que o Parlamento lhe dê o adequado tratamento legislativo";

39) Ministro Ricardo Lewandowiski: "reconhecida a união homoafetiva como entidade familiar, aplicam-se a ela as regras do instituto que lhe é mais próximo, qual seja, a união estável heterossexual, mas apenas nos aspectos em que são assemelhados, descartando-se aqueles que são próprios da relação entre pessoas de sexo distinto". 
40) Ministro Gilmar Mendes: "apesar de o Poder Legislativo debruçar-se sobre o tema há mais de 15 anos, até hoje não conseguiu chegar a consenso básico para aprovação de qualquer regulamentação";

41) Ministro Gilmar Mendes: "a demora em aprovar legislação gera nos interessados angústia natural e um sentimento de desproteção, para os quais buscam solução no Judiciário";

42) Ministro Gilmar Mendes: "mas, não estamos a falar apenas da falta de uma disciplina legislativa, mas do reconhecimento do direito de minorias, de direitos fundamentais básicos. E, nesse ponto, não se trata de ativismo judicial, mas de cumprimento da própria essência da jurisdição constitucional, de acordo com o art. $5^{\circ}$, inciso XLI, da Constituição ao determinar que "a lei punirá qualquer discriminação atentatória dos direitos e liberdade fundamentais";

43) Ministro Gilmar Mendes: "limito-me a reconhecer a existência da união entre pessoas do mesmo sexo, por fundamentos jurídicos próprios e distintos daqueles explicitados pelo Ministro Ayres Brito, e com suporte na teoria do pensamento possível determinar a aplicação de um modelo de proteção semelhante - no caso, o que trata da união estável - naquilo que for cabível, nos termos da fundamentação aqui apresentada, sem me pronunciar sobre outros desdobramentos";

44) Ministro Marco Aurélio: "as garantias de liberdade religiosa e do Estado laico impedem que concepções morais religiosas guiem o tratamento estatal dispensado a direitos fundamentais, tais como o direito à dignidade da pessoa humana, o direito à autodeterminação, o direito à privacidade e o direito à liberdade de orientação sexual";

45) Ministro Marco Aurélio: "inexiste vedação constitucional à aplicação do regime da união estável a essas uniões, não se podendo vislumbrar silêncio eloquente em virtude da redação do $\S 3^{\circ}$ do art. 226";

46) Ministro Marco Aurélio: "nesse contexto, a literalidade do artigo 1.723 do Código Civil está muito aquém do que consagrado pela Carta de 1988. Não retrata fielmente o propósito de reconhecer direitos a grupos minoritários".

47) Ministro Celso de Melo: "Os adversários da possibilidade de reconhecimento da união estável entre pessoas do mesmo sexo invocam a redação do art. $226, \S 3^{\circ}$ da Constituição Federal, pois tal preceito teria barrado a possibilidade do reconhecimento da união homoafetiva no Brasil, enquanto não fosse aprovada emenda alterando o texto constitucional. O argumento que se apega apenas na literalidade do texto não procede"; 
48) Ministro Celso de Melo: "os princípios constitucionais são os vetores que apontam no sentido de que a exegese das normas setoriais da Constituição - como o nosso $\S 3^{\circ}$ do art. 226 - deve buscar a inclusão e não a exclusão dos estigmatizados; a emancipação dos grupos vulneráveis e não a perenização do preconceito e da desigualdade";

49) Ministro Cezar Peluso: “As normas aplicáveis à solução da questão posta são as que se aplicam à união estável entre o homem e a mulher. Mas nem todas, porque não se trata de situações absolutamente idênticas. E, portanto, é preciso respeitar aquilo que cada instituição, em si, tem de particular, não apenas por sua natureza extrajurídica, mas também pela própria natureza normativa de cada qual";

50) Ministro Cezar Peluso: "há, a partir desse julgamento, uma convocação ao Poder Legislativo para que assuma a tarefa de regulamentar esta equiparação";

51) No Brasil, vige o princípio da interpretação conforme a Constituição, o que implica dizer que os textos legais não são autossuficientes, mas que dependem de uma leitura dos princípios constitucionais, a fim de lhes dar suporte valorativo, integrando a regra jurídica ao ordenamento, como um todo harmônico;

52) Afirmar que a decisão é dotada de eficácia erga omnes e que tem efeito vinculante significa dizer que além de ser uma decisão geral, que atinge a todos, também é uma decisão que vincula a todos, em geral, inclusive os integrantes do Poder Judiciário e da Administração Pública. Desse modo, não há para o administrador e nem para o magistrado espaço para a discricionariedade e nem para o livre convencimento;

53) Em que pese o voto do Senhor Ministro Ricardo Lewandowski, que aplicou, pelo processo de integração analógico, às uniões homoafetivas as "prescrições legais relativas às uniões estáveis heterossexuais, excluídas aquelas que exijam a diversidade de sexo para o seu exercício, até que sobrevenham disposições normativas específicas que regulem tais relações", a conclusão da Corte Suprema não encampou esse entendimento, ampliando assim o conceito de união estável, para nele incluir toda e qualquer relação duradoura, pública e contínua, com intuito de constituir família, independentemente do sexo ou orientação sexual do casal;

54) Na medida em que o matrimônio assegura direitos que não são conferidos àqueles que vivem em união estável, efeitos estes, inclusive, mais benéficos, resta evidenciado o interesse jurídico da conversão;

55) Finalmente, no entendimento de que o Superior Tribunal de Justiça, cumprindo sua missão de uniformizar o direito infraconstitucional, não pode conferir à lei uma 
interpretação que não seja constitucionalmente aceita e com fulcro no julgamento conjunto da ADPF No $132 / R J$ e ADI No 4.277/DF pelo Supremo Tribunal Federal julgou não existir vedação expressa a que se habilitem para o casamento pessoas do mesmo sexo. E ainda que a vedação implícita na interpretação dos artigos 1.514, 1.521, 1.523, 1.535, e 1.565 do Código Civil é constitucionalmente inaceitável, sob pena de ofensa aos princípios constitucionais da igualdade, da não discriminação, da dignidade da pessoa humana, e do pluralismo e livre planejamento familiar;

56) Tendo em vista que cada Estado autorizava ou não a conversão da união homoafetiva em casamento e a habilitação direta para o casamento homoafetivo, a padronização e solução dessas controvérsias em todo o território nacional foram pedidas pelo IBDFAM (Instituto Brasileiro de Direito de Família), o PSOL (Partido Socialismo e Liberdade) e a ARPEN/RJ (Associação dos Registradores de Pessoas Naturais do Rio de Janeiro) ao CNJ (Conselho Nacional de Justiça), a fim de que se regulamentasse, em âmbito nacional, o casamento civil entre pessoas do mesmo sexo;

57) Em 14 de maio de 2013, o Conselho Nacional de Justiça emitiu a Resolução $N^{\circ}$ 175 que dispõe sobre a habilitação, celebração de casamento civil, ou de conversão de união estável em casamento, entre pessoas do mesmo sexo;

58) Em 21 de maio de 2013, o PSC (Partido Social Cristão) entrou com um Mandado de Segurança - MS 32077 MC/DF, com pedido de liminar no Supremo Tribunal Federal pedindo a suspensão da Resolução 175 , do CNJ, de 14/05/2013, sob o fundamento de que o CNJ se apropriou de prerrogativas do Congresso Nacional e do PSC, por ter aprovado uma norma que não passou pelo processo legislativo;

59) Em 28/05/2013, o Ministro Luiz Fux, do Supremo Tribunal Federal, decidiu extinguir o Mandado de Segurança - MS 32077 MC/DF tendo em vista que o Mandado de Segurança não é o procedimento adequado para contestar a regra. Segundo o Ministro, a Resolução do CNJ qualifica-se como uma "lei em tese" e, nestes casos, a Súmula 266 do STF não permite que a regra seja atacada por meio de Mandado de Segurança;

60) É que a Resolução 175 do CNJ possui nítido perfil normativo, na medida em que disciplina, de forma genérica, abstrata e impessoal, a habilitação, celebração de casamento civil, ou de conversão de união estável em casamento, entre pessoas do mesmo sexo;

61) A referida Resolução, à semelhança das espécies normativas primárias, retira seu fundamento de validade diretamente da Lei Fundamental, e não de outro ato normativo que a tenha precedido. A Resolução 175/2013 por buscar seu fundamento de validade no art. 
226, $\S 3^{\circ}$, da $\mathrm{CRFB} / 88$, na interpretação que lhe foi conferida pelo Supremo Tribunal Federal e pelo Superior Tribunal de Justiça, reveste-se de generalidade, autonomia, abstração e impessoalidade. Exatamente porque ostenta tais apanágios, a Resolução $\mathrm{n}^{\mathrm{o}}$ 175/2013 qualifica-se como "lei em tese".Destarte, a Resolução no 175/2013 do CNJ expõe-se ao controle abstrato de constitucionalidade, e não pela via incidental do mandado de segurança;

62) Em 06/06/2013, o PSC (Partido Social Cristão) entrou com Ação Direta de Inconstitucionalidade ADI 4966, Relator Ministro Gilmar Mendes, questionando a Resolução no 175/2013 do CNJ;

63) A Resolução $n^{\circ} 175 / 2013$ do CNJ também vem sendo questionada pelo Poder Legislativo, por meio de dois projetos de decreto legislativo que visam sustar atos normativos do Poder Executivo. A justificativa de ambos os projetos é o inciso XI, do art. 49, da Constituição Federal, que estabelece ser competência exclusiva do Congresso Nacional zelar pela preservação da sua competência legislativa em face da atribuição normativa dos outros Poderes;

64) O que pauta a conduta da Administração não é só a lei em sentido formal, mas o Direito como um todo, incluindo a Constituição e os princípios que regem o nosso ordenamento. Portanto, são muitas as dificuldade que se apresentam para o intérprete decidir se no desempenho do poder regulamentar, o Executivo extrapolou a autorização constitucional em questão;

65) Entende o professor Álvaro Villaça Azevedo que atualmente existem as seguintes espécies de casamento e de união estável: o casamento civil típico e o casamento civil atípico, casamento religioso, com efeitos civis, união estável típica e união estável atípica;

66) O casamento civil atípico é o que não foi regulado pelo Código Civil. E este difere do típico, porque é entre pessoas do mesmo sexo e foi criado jurisprudencialmente pelo Superior Tribunal de Justiça;

67) A união estável atípica ocorre da mesma forma que a típica. Somente entre pessoas do mesmo sexo;

68) Vimos que nos países onde a Teoria da Inexistência do Casamento restou modificada, houve alteração legislativa para acolher o casamento entre pessoas do mesmo sexo; 
69) Portanto, por falta de mudança no Código Civil, a Teoria da Inexistência do Casamento ainda não foi modificada, embora existam jurisprudencialmente o casamento homoafetivo e a união homoafetiva;

70) Compartilhando do entendimento do professor Álvaro Villaça Azevedo de que o artigo 226 da Constituição Federal é meramente exemplificativo, pode-se concluir que este acolhe as uniões homoafetivas sem necessidade de mudança na Constituição Federal;

71) Quanto ao casamento, também não há necessidade de mudança constitucional, pois o texto da Constituição Federal não o veda expressamente;

72) Quanto ao Código Civil, faz-se necessária uma mudança legislativa para acolher a união homoafetiva e o casamento homoafetivo;

73) Com relação à filiação homoparental, no Brasil, não há norma em nosso ordenamento jurídico que a proíba, porém não há legislação específica sobre o tema. As conquistas vêm de batalhas junto ao Poder Judiciário;

74) Estudos científicos demonstram que casais homossexuais formados por gays e lésbicas constroem relacionamentos estáveis com compromissos recíprocos os quais são equivalentes às relações de casais heterossexuais. Além disso, com relação à paternidade e à maternidade afirmam que não existe base científica para concluir que pais homossexuais sejam menos preparados ou capazes do que pais heterossexuais, ou que crianças de pais homossexuais sejam, de alguma maneira, menos saudáveis psicologicamente ou que tenham mais dificuldades de adaptação;

75) Os casais homossexuais podem ter seus filhos por meio da adoção, da reprodução medicamente assistida ou da filiação socioafetiva;

76) Com relação à adoção por casais do mesmo sexo, o Superior Tribunal de Justiça (STJ), já se posicionou favoravelmente, conforme visto no Recurso Especial No 889.852RS, de 27 de abril de 2010;

77) Com relação à reprodução medicamente assistida, não temos legislação a respeito e são seguidas as regras deontológicas estabelecidas pelas Resoluções do Conselho Federal de Medicina, sendo que a última Resolução do CFM 2013/2013 textualmente assegura que é permitido o uso de técnicas de RA para relacionamentos homoafetivos e pessoas solteiras, respeitado o direito de objeção de consciência médica;

78) A necessidade de se encontrar os limites, que se iniciam como éticos e que irão encontrar a sua formulação final no sistema jurídico é de fundamental importância. Por este motivo seria muito importante uma legislação sobre as técnicas de reprodução 
medicamente assistida, conforme já existem na Espanha, Portugal, Argentina e tantos outros países;

79) Neste sentido, preocupa-nos a multiparentalidade advinda de um "projeto de família pluriparental" utilizando-se das técnicas de reprodução medicamente assistida. Uma lei deixaria claros os limites e impediria que se gerassem crianças com tantos pais e mães quantos a imaginação humana pudesse alcançar;

80) O esboço do projeto de lei apresentado não se preocupou em prever todas as necessidades e implicações de modificação da legislação, para que fossem acolhidas a união homoafetiva e o casamento homoafetivo tendo em vista não ser este o objetivo do trabalho. 


\section{REFERÊNCIAS BIBLIOGRÁFICAS}

\section{Livros}

ALVES, José Carlos Moreira. Direito Romano. 15. Ed. Rio de Janeiro: Gen, Forense, 2012.

AZEVEDO, Álvaro Villaça. Dever de Coabitação. Inadimplemento. 2. ed. São Paulo: Atlas, 2009.

. Direito de Família. Curso de Direito Civil. São Paulo: Atlas,

2013.

.Do Concubinato ao Casamento de Fato. 2. ed. Belém:

CEJUP, 1987.

.Estatuto da Família de Fato. 3. ed. São Paulo: Atlas: 2011.

AZEVEDO, Antônio Junqueira de. Negócio Jurídico: existência, validade e eficácia. 4. ed. São Paulo: Saraiva, 2002.

BASSET, Ursula C. El cambio de paradigma de la nueva ley argentina sobre el matrimonio. In: Direito e Dignidade da Família. Do começo ao fim da vida. Org. Antonio Jorge Pereira Júnior, Débora Gozzo, Wilson Ricardo Ligiera. São Paulo: Almedina, 2012.

BIMBI, Bruno. Casamento Igualitário. Tradução de Rosanne M. Nascimento de Souza. Rio de Janeiro: Garamond, 2013.

BOSWELL, John. Christianity, Social Tolerance, and Homosexuality. Gay People in Western Europe from the Beginning of the Christian Era to the Fourteenth Century. Chicago and London: University of Chicago Press, 1981.

BRANDÃO, Débora Vanessa Caús. Parcerias Homossexuais. Aspectos Jurídicos. São Paulo: RT, 2002.

CAHALI, Yussef Said. O Casamento Putativo. 2 ed.. São Paulo: RT, 1979. 
CHAVES, Marianna. Homoafetividade e Direito. Proteção Constitucional, Uniões, Casamento e Parentalidade. 2. ed. atualizada de acordo com a ADI 4.277 (julgada em conjunto com a ADPF 132) do STF. Curitiba: Juruá, 2012.

CZAJKOWSKI, Rainer. União Livre. À luz da no Lei 8.971/94 e da Lei no 9.278/96. 2 ed., revista e ampliada. Curitiba: Juruá, 2002.

DALlA, Danilo. Ubi Venus Mutatur. Omosessualità e Diritto nel Mondo Romano. Milano: Dtt. A. Giuffrè Editore, 1987.

DIAS, Maria Berenice. Diversidade Sexual e Direito Homoafetivo. 2 tiragem. São Paulo: Revista dos Tribunais, 2011.

Manual de direito das Famílias. 6 ed. revista, atualizada e ampliada. São Paulo: RT, 2010.

RT, 2011.

União Homoafetiva. O preconceito \& a Justiça, 5. ed. São Paulo:

DINIZ, Maria Helena. O Estado Atual do Biodireito. 8 ed. São Paulo: Saraiva, 2011.

Curso de Direito Civil Brasileiro. Direito de Família. Vol. 5, 25 ed. São Paulo: Saraiva, 2010.

FOUCAULT, Michel. História da sexualidade. O uso dos prazeres. Vol. 2. Trad. Maria Thereza da Costa Albuquerque. Rio de Janeiro: Graal, 1984.

FRANÇA PINTO, Ana Cristina de Barros Monteiro. Reflexões sobre o vínculo homoafetivo no direito sucessório. In 10 anos de Vigência do Código Civil Brasileiro de 2002. Estudos em homenagem ao professor Carlos Alberto Dabus Maluf. São Paulo: Saraiva, 2013.

FUJITA, Jorge Shiguemitsu. Curso de Direito Civil, Direito de Família. São Paulo: Juarez de Oliveira, 2000.

Filiação. 2. ed. São Paulo: Editora Atlas, 2011.

.et al. Filiação na Contemporaneidade. In Direito de Família

no Novo Milênio. Estudo em homenagem ao professor Álvaro Villaça Azevedo. São Paulo: Editora Atlas, 2010.

GIRARDI, Viviane. Famílias Contemporâneas, Filiação e Afeto. A Possibilidade Jurídica da Adoção por Homossexuais. Porto Alegre: 2005.

HELMINIAK, Daniel A.. O que a Bíblia realmente diz sobre a homossexualidade. Tradução Eduardo Teixeira Nunes. 1. ed. São Paulo: Edições GLS, 1998.

LÔBO, Paulo. Direito Civil. Famílias. 3. ed. são Paulo: Saraiva, 2010. 
LOPES, Miguel de Serpa. Curso de Direito Civil. Vol. 1, 7. ed. revista e atualizada pelo Prof. José Serpa Santa Maria. Rio de Janeiro: Freitas Bastos, 1995.

MALUF, Adriana Caldas do Rego Freitas Dabus Maluf. Novas Modalidades de Família na Pós-Modernidade. São Paulo: Atlas, 2010.

MALUF, Carlos Alberto Dabus. MALUF, Adriana Caldas do Rego Freitas Dabus. Curso de Direito de Família. São Paulo: Saraiva, 2013.

MIRANDA, Francisco Cavalcanti Pontes de. Tratado de Direito Privado: Parte Especial. Tomo VII, Direito de Personalidade, Direito de Família. Direito matrimonial (Existência e validade do casamento), atualizado por Rosa Maria de Andrade Nery, RT: São Paulo, 2012.

MONTEIRO, Washington de Barros; SILVA, Regina Beatriz Tavares da. Curso de Direito Civil, Direito de Família, 39 ed. São Paulo, 2009.

MOREIRA, Adilson José. União Homoafetiva. A Construção da Igualdade na Jurisprudência Brasileira. 2. ed. revista e atualizada. Curitiba: Juruá, 2012.

PEREIRA, Caio Mário da Silva. Instituições de Direito Civil. Direito de Família. Vol. V, 20 ed. atualizada por Tânia da Silva Pereira. Rio de Janeiro: Forense, 2012.

RIOS, Roger Raupp. O princípio da Igualdade e a Discriminação por Orientação Sexual. A Homossexualidade no direito Brasileiro e Norte-Americano. São Paulo: Revista dos Tribunais, 2002.

A igualdade de tratamento nas relações de família. In A Justiça e os Direitos de Gays e Lésbicas. Jurisprudência Comentada. Francisco Loyola de Souza...[et.al]; Orgs. Célio Golin. Porto Alegre: Sulina, 2003.

A homossexualidade no Direito. Porto Alegre: Livraria do

Advogado, 2001.

SAN TIAGO DANTAS, Francisco Clementino. Direito de Família e das Sucessões, revista e atualizada por José Gomes Bezerra Câmara e Jair Barros. Rio de Janeiro: Forense, 1991.

SCALQUETTE, Ana Cláudia S.. Estatuto da Reprodução Assistida. São Paulo: Saraiva, 2010.

SCHWAB, Jean-Luc; BRAZDA, Rudolf. Triângulo rosa. Um homossexual no campo de concentração nazista. São Paulo: Mescla, 2011.

SILVA, Regina Beatriz Tavares da. Código Civil Comentado. 6 ed.. São Paulo: Saraiva, 2008. 
SILVA, José Afonso. Comentário Contextual à Constituição. São Paulo: Malheiros, 2005.

SPENCER, Colin. Homossexualidade: uma história. Tradução de Rubem Mauro Machado. 2. ed.. Rio de Janeiro: Record, 1995.

SUETÔNIO. A Vida dos Doze Césares. Tradução: Pietro Nassetti. São Paulo: Martin Claret, 2013.

TORINO, Raffaele. La Tutela Della Vita Familiare Delle Coppie Omossexuali. Nel diritto comparato, europeo e italiano. Torino: G. Giappichelli Editore, 2012.

VALLE, Vanice Regina Lírio do (org). Ativismo Judicial e o Supremo Tribunal Federal: laboratório de análise jurisprudencial do STF. Curitiba: Juruá, 2009.

VECCHIATTI, Paulo Roberto Iotti. Manual da Homoafetividade. Da possibilidade jurídica do casamento civil, da união estável e da adoção por casais homoafetivos. 2. ed. São Paulo: Gen, Médodo, 2012.

VELOSO, Zeno. Nulidade e inexistência. In: 10 anos de Vigência do Código Civil Brasileiro de 2002. Estudos em homenagem ao professor Carlos Alberto Dabus Maluf. São Paulo: Saraiva, 2013.

VENOSA, Sílvio de Salvo. Direito Civil. Direito de Família. Vol. VI, 13 ed.. São Paulo: Atlas, 2013.

Artigos

AZEVEDO, Álvaro Villaça. União Homoafetiva. Revista Juris da FAAP, ano III, vol. 5jan. a jun., 2011, p. 9-10.

. Uniões entre pessoas do mesmo sexo. Revista da Faculdade

de Direito da USP. V. 94, 1999.

. Espécies Atuais de Casamento e de União Estável. Revista Nacional de Direito de Família e Sucessões. Lex Magister, IASP, jul./ago./2014, p. 7-19.

BALIARDO. Rafael. CNJ autoriza casamento gay em cartórios. Disponível em: http://www.conjur.com.br/2013-mai-14/cnj-determina-cartorios-convertam-uniao-est...

Acesso em 15 mai. 2013.

BAZÁN, Oswaldo. Homossexualidade. Disponível em http://casamentocivligualitario.com.br/opinioes/. Acesso em 01 jan. 2014. 
BEZERRA, Elton. PSC questiona resolução do CNJ sobre casamento gay. Disponível em: $\quad$ http://www.conjur.com.br/2013-mai-21/psc-stf-resolucao-cnj-casamentohompafetivo... Acesso em 22 mai. 2013.

BOISSON Marine, VERJUS Anne. Quand connaître, c'est reconnaître? Ce role de l'expertise familiale dans la production d'un sens commun du parent (homosexual). Droit e Société. No 60/2005.

CUNHA FILHO, Alexandre Jorge Carneiro da. Lei e regulamento: apontamentos sobre o caráter inovador inerente a todas as formas de manifestação do poder normativo estatal. BDA - Boletim de Direito Administrativo, São Paulo, NDJ, ano 31, n. 7, p. 856-894, jul. 2015.

DIAS, Maria Berenice. Comentário da Decisão. Revista IBDFAM, Famílias e Sucessões. Mar./Abr./2015, p. 151.

FERRAZ JUNIOR, Tercio Sampaio. Jurisprudência passou a ter mais importância que a própria lei. Disponível em: http://www.conjur.com.br/2014-set-29/jurisprudenciapassou-importancia-propria-lei... Acesso em 30 set. 2014.

GAMA, Guilherme Calmon Nogueira da. A reprodução assistida heteróloga sob a ótica do Novo Código Civil. Revista Brasileira de Direito de Família. Porto Alegre: Síntese, IBDFAM, v. 5, no 19, ago./set., 2003, p. 55.

ITABORAY, Lucas Paoli; ZHU Jingshu. Homofobia do Estado. Análise mundial das leis: criminalização, proteção e reconhecimento do amor entre pessoas do mesmo sexo. 8. ed., mai. 2013. Disponível em: http://old.ilga.org/Statehomophobia/ILGA_State_Sponsored_Homophobia_2013_portugue se.pdf. Acesso em 22 dez. 2013.

MANSILLA, Guillermo Cerdeira Bravo de. Constitucionalidad de la Ley 13/2005, sobre el matrimonio homossexual: Um ejemplo - Hoy - de interpretación sociológica o evolutiva, fundada em razones de igualdad. Revista de Derecho Privado. Marzo-Abril, 2013, p. 25 86.

MARTINS, Ives Gandra da Silva. A disciplina jurídica do homossexualismo. Scientia Ivridica. Revista de Direito Comparado Português e Brasileiro. Tomo LX, No 327 Set./Des., 2011, p. 495.

MARTINS, Sandra Regina Carvalho (Coordenadora); VIANA JÚNIOR, Edilberto Cavalcante; PUGLIESE, Ellen Cristina; CAFOLLA, Marcos; ARAUJO, Paula Cristina; BENTO, Yeda Peixinho. Breves considerações sobre o PLS no 470/2013, sob a ótica do 
Código Civil Vigente. Revista Científica Virtual, Formatos Familiares Contemporâneos, ESA-OAB/SP, ano V, n ${ }^{\circ}$ 18, 2014, p. 56-66. Disponível em: http://www.esaoabsp.edu.br/revista/edicao18/index.swf. Acesso em 28 out. 2014.

MELO, João Ozorio de. Suprema Corte começa a debater futuro do casamento gay nos EUA. Disponível em: http://www.conjur.com.br/2015-abr-27-suprema-corte-comecadebater-futuro-casame... Acesso em 17 mai. 2015.

MOZOS, José Luis de Los. El Negócio Jurídico (Estudios de Derecho Civil). Revista General de Legislación y Jurisprudencia, Madrid, abr. 1960.

PINHEIRO, Aline. Retrospectiva 2013. Gays ganham direito de formar família na Europa. Disponível em: http://www.conjur.com.br/2014-jan-04/ano-2013-conquistasdireitos-homossexuais?i... Acesso em 06 jan. 2014.

PINHEIRO, Aline. Corte europeia reconhece direito de gays formarem família. Disponível em: http://www.conjur.com.br/2013-nov-07/gays-tambem-direito-formarfamilia-decide-c...Acesso em 06 jan. 2014.

PINHEIRO, Aline. Corte Europeia veta regras diferentes para casais gays. Disponível em: http://www.conjur.com.br/2013-fev-19/europa-decide-definicao-tradicional-familian... Acesso em 06 jan. 2014.

PINHEIRO, Aline. Direito dos gays é pouco reconhecido no Leste Europeu. Disponível em: http://www.conjur.com.br/2013-ago-21/direito-homossexuais-ainda-reconhecidoleste... Acesso em 06 jan. 2014.

PIVA, Rui Carvalho. Decisão judicial converte em casamento a união estável entre duas pessoas do sexo masculino. Revista JURIS da Faculdade de Direito da FAAP. Vol. 5, ano III, 2011, p. 113-116.

RODRIGUES, Irene; BÉO, Cíntia Regina. União Homoafetiva: Aspectos Civis e Constitucionais. Revista da Faculdade de Direito da Universidade de São Paulo. Vol. 99, 2004, p. 669.

ROMANO, Angela. Omosessualità, Amore e Potere Nella Società Romana. Labeo. Rassegna di Diritto Romano. Jovene - 36(1990) 2: Napoli.

ROVER, Tadeu. Para advogados, decisão do CNJ é válida, mas falta lei. Disponível em http://www.conjur.com.br/2013-mai-14/advogados-dizem-decisao-cnj-valida-porem-...

Acesso em 15 mai. 2013.

SILVA. Regina Beatriz Tavares da. Estatuto das famílias retoma proposições desastrosas. Disponível em: http://www.conjur.com.br/2013-nov-19-regina-tavares-silvafamilias-retom-. Acesso em 19 nov. 2013. 
SIMÃO, José Fernando. Se Estatuto da Família for aprovado, o STF o declarará inconstitucional. Disponível em http://www.professorsimao.com.br/artigos.aspx?id=320. Acesso em 21 jul. 2015.

SOUZA, Thiago Serrano Pinheiro de. O Papel das Cortes Constitucionais Brasileiras e SulAfricana no Reconhecimento da União Homoafetiva. Revista Brasileira de Direito das Famílias e Sucessões. IBDFAM. Out/Nov. Vol. 36, 2013, p. 100.

TEODORO, Renata. Ativismo judicial é o que separa Legislativo do Judiciário. Disponível em: http://www.conjur.com.br/2014-abr-28/teori-ativismo-judiciasepara=legislativo-judic... Acesso em 29 abr. 2014.

\section{Teses e Dissertações}

GIULIANI, Ivani Martins Ferreira. Casamento Inexistente. Dissertação de Mestrado, Direito Civil, Faculdade de Direito da Universidade de São Paulo, 1985.

MALUF, Carlos Alberto Dabus. A inexistência na teoria das nulidades. Tese apresentada ao Departamento de Direito Civil da Faculdade de Direito da USP para provimento de cargo de Professor Titular, 2006.

VIANA, Rui Geraldo. A Família e a filiação. Tese apresentada ao Departamento de Direito Civil da Faculdade de Direito da USP para provimento de cargo de Professor Titular, 1996.

\section{Seminário}

SILVA, José Afonso da. José Afonso da Silva aborda o ativismo judicial em seminário da OAB. Disponível em: http://www.oab.org.br/util/print/25758?print=Noticia. Acesso em 13 jun. 2013

\section{Jurisprudência Nacional}

BRASIL. Supremo Tribunal Federal. ADI 4966- Ação Direta de Inconstitucionalidade. Disponível em: http://www.stf.jus.br/portal/processo/verProcessoAndamento.asp?incidente=4419751. Acesso em 02 jul. 2015.

BRASIL. Supremo Tribunal Federal. Voto Ministro Ayres Brito ADI 4277. Disponível em: http://www.stf.jus.br/arquivo/cms/noticiaNoticiaStf/anexoADI4277revisado.pdf . Acesso em 19 jan. 2014. 
BRASIL. Supremo Tribunal Federal. Voto Ministro Luiz Fux na ADI 4277. Disponível em: http://www.stf.jus.br/arquivo/cms/noticiaNoticiaStf/anexo/ADI4277LF.pdf. Acesso em 19 abr. 2015.

BRASIL. Supremo Tribunal Federal. Voto Ministra Cármen Lúcia na ADI 4277. Disponível em: http://www.stf.jus.br/arquivo/cms/noticiaNoticiastf/anexo/adi4277clpdf. Acesso em 20 mai. 2015.

BRASIL. Supremo Tribunal Federal. Voto Ministro Ricardo Lewandowiski na ADI 4277. Disponível

em: http://www.stf.jus.br/arquivo/cms/noticiaNoticiastf/anexo/ADI4277RL.pdf. Acesso em 03 fev. 2014.

BRASIL. Supremo Tribunal Federal. Voto Ministro Joaquim Barbosa na ADI 4277. Disponível http://redir.stf.jus.br/paginadorpub/paginador.jsp?docTP=ACdicID=628635. Acesso em 05 jul. 2015.

BRASIL. Supremo Tribunal Federal. Voto Ministro Gilmar Mendes na ADI 4277/DF. Disponível em: http://redir.stf.jus.br/paginarpub/paginador.jsp2docTP=AC\&doc=ID=628635. Acesso em 07 jul. 2015.

BRASIL. Supremo Tribunal Federal. Voto Ministra Ellen Grace na ADI 4277/DF. Disponível em: http://www.stf.jus.br/portal/cms/verNoticiaDetalhe.asp?idConteudo=178937. Acesso em 07 jul. 2015.

BRASIL. Supremo Tribunal Federal. Voto do Ministro Marco Aurélio na ADI 4277. Disponível em: http://www.stf.jus.br/arquivo/cms/noticiaNoticiaStf/anexo/ADI4277MA.pdf. Acesso em 28 jun. 2015.

BRASIL. Supremo Tribunal Federal. Voto do Ministro Celso de Mello. Disponível em: http://www.stf.jus.br/arquivo/cms/noticiaNoticiaStf/anexo/ADI4277CM.pdf. Acesso em 05 jul. 2015.

BRASIL. Supremo Tribunal Federal. Voto do Ministro Cezar Peluso na ADI 4277/DF. Disponível em: http://redir.stf.jus.br/paginadorpub/paginador.jsp2docTP=AC\&docID=628635. Acesso em 05 jul. 2015.

BRASIL. Supremo Tribunal Federal. Ementa e Acórdão da ADI 4277/DF. Disponível em: http://redir.stf.jus.br/paginadorpub/paginador.jsp?docTP=AC\&docID=628635. Acesso em 05 jul. 2015. 
BRASIL. Supremo Tribunal Federal. RE $\mathrm{N}^{\mathrm{o}}$ 846.102. Disponível em: http://www.conjur.com.br/2015-mar-20/carmen-lucia-reconhece-adocao-restricao-ida... Acesso em 20 mar. 2015.

BRASIL. Supremo Tribunal Federal. Agravo Regimental no Recurso Extraordinário. RE $\mathrm{N}^{\circ} \quad 477554 \quad \mathrm{AgR} \quad / \quad$ MG. Disponível em: http://www.stf.jus.br/portal/jurisprudencia/listarJurisprudenciaDetalhe.asp?s1=000178 ... Acesso em 04 fev. 2015.

BRASIL. Supremo Tribunal Federal. ADPF 291 - Arguição de Descumprimento de Preceito Fundamental (Eletrônico). Disponível em: http://www.stf.jus.br/portal/cms/verNoticiaDetalhe.asp?idconteudo=248739. Acesso em 17 abr. 2015.

BRASIL. Supremo Tribunal Federal. Súmula n ${ }^{\circ}$ 380, de 03/04/1964. Disponível em: www.010.dataprev.gov.br/sislex/pagainas/75/STF/380.htm. Acesso em 03 abr. 2014.

BRASIL. Superior Tribunal de Justiça. Recurso Especial Nº 889.852-RS (2006/02091374). Disponível em: https://ww2.stj.jus.br/processo/revista/documento/mediado/?componente=aTC\&sequencial $=9823377 \&$ num_registro $=2$. Acesso em 10 ago. 2010 .

BRASIL. Superior Tribunal de Justiça. Recurso Especial No 1.281.093-SP (2011/02016852). Disponível em: https://ww2.stj.jus.br/processo/revista/documento/mediado=ATC\&sequencia=26262373\& num_registro=201102016852. Acesso em 04 fev. 2013.

BRASIL. Superior Tribunal de Justiça. REsp $\mathrm{n}^{\circ}$ 148897-MG. Disponível em: http://w2stj.jus.br/processo/ita/documento/?num_registro=199700661245\&dt_publi.

Acesso em 17 nov. 2013.

BRASIL. Superior Tribunal de Justiça. REsp $\mathrm{n}^{\mathrm{o}}$ 1.183.378-RS. Disponível em: http://ww2.stj.jus.br/processo/revista/documento/mediado/?componente=ATC\&sequencial $=18538707 \&$ num_registro $=$ Acesso em 11 jul. 2015 .

BRASIL. Superior Tribunal de Justiça. REsp No 238.715-RS. Disponível em http://www.stj.jus.br/SCON/jurisprudencia/doc.jsp?livre=Resp+238715\&\&b=ACOR\&p=tr ue\&=\&l. Acesso em 05 jan. 2014.

BRASIL. Superior Tribunal de Justiça. REsp No 820.475-RJ. Disponível em: http://www.stj.jus.br/SCON/jurisprudencia/doc.jsp?livre=820475\&\&b=ACOR\&1=10\&i= Acesso em 31 mai. 2011.

BRASIL. Superior Tribunal de Justiça. RESp No 1085646-RS. Disponível em: http://www.stj.jus.br/SCON/jurisprudencia/doc.jsp?livre=1085646\&\&b=ACOR\&p=true\&t $=\& \mathrm{l}=10 \& \mathrm{i}$. Acesso em 11 jul. 2015. 
BRASIL. Superior Tribunal de Justiça. RESp No 827.962-RS. Dispoonível em: http://stj.jusbrasil.com.br/jurisprudencia/21101223/recuros-especial-resp-827962-rs-2... Acesso em 02 fev. 2014.

BRASIL. Superior Tribunal de Justiça. RESp No 932653-RS. Disponível em: http://www.stj.jus.br/SCON/jurisprudencia/doc.jsp?livre=1199667\&\&b=ACOR\&p=TR... Acesso em 06 jul. 2015.

BRASIL. Superior Tribunal de Justiça. RESp No 1370542-DF. Disponível em: http://www.stj.jus.br/SCONjurisprudencia/doc.jsp?tipo_visualizacao=RESUMO\&livre=13 70542\&b... Acesso em 06 jul. 2015.

BRASIL. Superior Tribunal de Justiça. RESp No 1204425-MG. Disponível em: http://www.stj.jus.br/SCON/jurisprudencia/doc.jsp?livre=1204425\&\&b=ACOR\&p=tr... Acesso 06 jul. 2015.

BRASIL. Superior Tribunal de Justiça. RESp No 1302467-SP. Disponível em: http://www.stj.jus.br/SCON/jurisprudencia/doc.jsp?livre=1302467\&\&b=ACOR\&p=true\&t $=\& \mathrm{l}=10 \& \mathrm{i}$ Acesso em 08 jul. 2015.

BRASIL. Superior Tribunal de Justiça. RESp $\mathrm{N}^{\circ}$ 889.852-RS. Disponível em: http://ww2.stj.jus.br/processo/revist/documento/mediado/?componente=ATC\&sequencia= 9823377\&num_registro=2. Acesso em 10 ago. 2010.

BRASIL. Superior Tribunal de Justiça. RESp No 1.281.093-SP. Disponível em: http://ww2.stj.jus.br/processo/revista/documento/mediado=ATC\&sequencia=26262373\&n

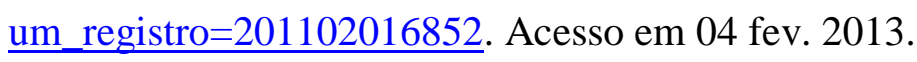

BRASIL. Superior Tribunal Eleitoral. RESPE 24.564, TSE. Disponível em www.gilmarmendes.org.br/index.php?option...respe... Acesso em 11 jul. 2015.

BRASIL. Tribunal Regional Federal, Quinta Região. Apelação Cível No 08002607720124058300. Disponível em: http://www.trf5.jus.br/Jurisprudencia/JurisServlet?op=exibir\&tipo=1 Acesso em 11 jul. 2015.

BRASIL. RT - 427/238. Acesso em 10 out. 2013.

BRASIL. Tribunal de Justiça da Bahia. Apelação Cível No 16313-9/99. Disponível em: http://www.direitohomoafetivo.com.br. Acesso em 05 jul. 2015.

BRASIL. Tribunal de Justiça do Distrito Federal. Sentença do Distrito Federal. Disponível em: http://www.direitohomoafetivo.com.br/anexos/juris/1082.pdf. Acesso em 12 jul. 2015.

BRASIL. Tribunal de Justiça de Minas Gerais. Apelação Cível No 1.0024.04.5371218/002. Disponível em: http://www5.tjmg.jus.br/jurisprudencia/imprimirEspelho.do. Acesso em 10 nov. 2013. 
BRASIL. Tribunal de Justiça de Minas Gerais. Apelação Cível N ${ }^{\circ}$ 1.0024.06.9303246/001. Disponível em: http://www5.tjmg.jus.br/jurispudencia/pesquisaPalavrasEspelhoAcordao.do?palavras... Acesso em 11 jul. 2015.

BRASIL. Tribunal de Justiça de Minas Gerais. Apelação Cível No 1.0024.09.4845559/001. Disponível em: http://www5tjmg.jus.br/jurisprudencia/imprimirEspelho.do Acesso em fev. 2011.

BRASIL. Tribunal de Justiça de Minas Gerais. Apelação Cível No 1.047.08047254-6/001. Disponível em: http://www.ibdfam.org.br/?leisedecisoes\&jurisprudencia=1323. Acesso em 16 fev. 2012.

BRASIL. Tribunal de Justiça de Recife. Sentença da Comarca de Recife. Disponível em: http://www.direitohomoafetivo.com.br/anexos/juris/1101.pdf. Acesso em 12 jul. 2015.

BRASIL. Tribunal de Justiça do Rio de Janeiro. Sentença do Estado do Rio de Janeiro. Disponível em: http://www.direitohomoafetivo.com.br/anexos/juris/1207_888e650a59881fd7880d488963 6b01c6.pd. Acesso em 12 jul. 2015.

BRASIL. Tribunal de Justiça do Rio Grande do Norte. Apelação Cível No 2012003093-8. Disponível em: www.tjrs.jus.br. Acesso em 23 ago. 2012.

BRASIL. Tribunal de Justiça do Rio Grande do Sul. Apelação Cível N ${ }^{\circ} 70013801592$, Sétima Câmara Cível, Comarca de Bagé. Disponível em: http://jij.tjrs.jus.br/paginas/docs/jurusprudencia/Adocao_casal_formado_duas_pessoas... Acesso em 13 jun. 2015.

BRASIL. Tribunal de Justiça do Rio Grande do Sul. Apelação Cível No 70025659723. Disponível em: http:// www.tjrs.jus.br/busca/search?q=\&entsp=a_politica$\underline{\text { site } \& w c=2008 w c \_m c=1 \& o e=U T F-\& i e}$. Acesso em 05 jul. 2015.

BRASIL. Tribunal de Justiça do Rio Grande do Sul. Apelação Cível No 70048452643 TJRS. Disponível em: http://www.tjrs.jus.br/busca/search?q=\&entsp=a_politicasite\&wc_mc=1\&oe=UTF-8\&ie. Acesso em 05 jul. 2015.

BRASIL. Tribunal de Justiça do Rio Grande do Sul. Apelação Cível No 70001388982. Disponível em: http://www.tjrs.jus.br/busca/search?q=proxystylesheet=tjrs_index\&getfields=*\&entsp=a_p olitica. Acesso em 02 dez. 2013.

BRASIL. Tribunal de Justiça do Rio Grande do Sul. Apelação Cível No 70005488812. Disponível em: http://www.tjrs.jus.br/busca/search?proxystylesheet=tjrs_index\&client=tjrs_index\&filter=0

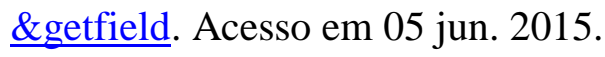


BRASIL. Tribunal de Justiça do Rio Grande do Sul. Apelação Cível No 70009550070. Disponível em: http://www.tjrs.br/busca/search?q-\&entsp=a_politica$\underline{\text { site } \& w c=2008 w c \_m c=1 \& o e=U T F-\& \& i e}$. Acesso em 05 jun. 2015.

BRASIL. Tribunal de Justiça do Rio Grande do Sul. Apelação Cível No 70009888017. Disponível em: http://www.tjrs.br/busca/search?q-\&entsp=a_politicasite \&wc=2008wc_mc=1\&oe=UTF-\&\&ie. Acesso em 05 jun. 2015.

BRASIL. Tribunal de Justiça do Rio Grande do Sul. Apelação Cível Nº 70016660383. Disponível em: http://www.tjrs.jus.br/busca/search?q=70021637145\&proxystylesheet=tjrs_index\&. Acesso em 09 jul. 2015.

BRASIL. Tribunal de Justiça do Rio Grande do Sul. AI599075496. Disponível em: http://www.direitohomoafetivo.com.br. Acesso em 17 nov. 2013.

BRASIL. Tribunal de Justiça do Rio Grande do Sul. Apelação Cível No 70035400530. Disponível em; $\quad \underline{\text { http://www.tjrs.br/busca/search?q=\&entsp=a politica- }}$ $\underline{\text { site } \& w c=2008 w c \_m c=180 e=U T F-8 \& i e}$. Acesso em 05 jul. 2015.

Brasil. Tribunal de Justiça do Rio Grande do Sul. Apelação Cível № 70062692876. Disponível em: http://www.tjrs.jus.br/busca/search?btnG=busca\&entsp=a_politica$\underline{\text { site } \& w c=200 \& w c \_m c=1 \& o e=}=$ Acesso em 19 jul. 2015.

BRASIL. Tribunal de Justiça do Rio Grande do Sul. Apelação Cível No 70013801592. Disponível em: http://jij.tjrs.jus.br/paginas/docs/jurisprudencia/Adocao_casal_formado_duas_pessoas... Acesso em 13 jun. 2015.

BRASIL. Tribunal de Justiça de Santa Catarina. Sentença Comarca de Itajaí/SC. Disponível em: http://www.direitohomoafetivo.com.br/anexos/juris/1172_bce652be95ec4ac5c7766dea728 8eceb.pc. Acesso em 12 jul. 2015.

BRASIL. Tribunal de Justiça de São Paulo. Apelação No 9000004-19.2011.8.26.0576. Disponível em: http://www.mpsp.mp.br/portal/infanciahome_C/adocao/Jurisprudencia. Acesso em 25 mai. 2015.

BRASIL. Tribunal de Justiça de São Paulo. Sentença Comarca de Jacareí/SP. Disponível em: http://www.direitohomoafetivo.com.br/znexos/juris/1079.pdf. Acesso em 12 jul. 2015.

BRASIL. Tribunal de Justiça de São Paulo. Apelação Cível $N^{o}$ 000433534.2012.8.26.0037. Disponível em: http://www.direitohomoafetivo.com.br/imprimejurisprudencia.php?ordem=1276.122... Acesso em 26 jul. 2012.

BRASIL. Tribunal de Justiça de São Paulo. Apelação Cível No 1090913220088260006. Disponível em: http://esaj.tjsp.jus.br/resultadocompleta.do... Acesso em 11 jul. 2015. 
BRASIL. Tribunal de Justiça de São Paulo. Juiz converte em casamento união estável de pessoas do mesmo sexo. Disponível em: imprensatj@tjsp.jus.br. Acesso em 29 jun. 2011.

BRASIL. Tribunal de Justiça de São Paulo. Processo No 0016266-45.2012.826.001. Gêmeos têm Registro de Nascimento em Nome de Duas Mães. Disponível em: http://www.tjsp.jus.br/Intranet/Noticia.aspx?Id=15036. Acesso em 27 jul. 2012.

\section{Resoluções}

BRASIL. Conselho Nacional de Justiça. Resolução No 175, de 14 de maio de 2013. Disponível em: www.cnj.jus.br/imprensa/resolucao_n_175.pdf. Acesso em 25 mai. 2013.

BRASIL. Resolução CFM no 2013/2013. Disponível em: http://www.portalmedico.org.br/CFM/2013 2013.pdf. Acesso em 07 jun. 2012.

BRASIL. Resolução CFP No 001/99. Disponível em http://site.cfp.org.br/wpcontent/uploads/1999/03/resolucao1999_1.pdf. Acesso em 16 nov. 2013.

\section{Legislação e Projetos de Leis Nacionais}

Constituição da República Federativa do Brasil. Disponível em: www.planato.gov.br/ccivil_03/constituicao.htm.

Código Civil. Disponível em: www.planalto.gov.br/ccivil_03/leis/2002/L10406.htm.

Lei No 12.783/2013 - Garante salário maternidade de quatro meses para mulheres e homens adotantes independentemente de orientação sexual. Disponível em: http://www.ibdfam.org.br/noticias/5174/Lei+garante_sal\%C3\%Alrio+maternidade+p...

Acesso em 29 out. 2013.

Lei 12.010/2009 - "Nova Lei de Adoção". Câmara aprova lei de adoção, mas casais homossexuais ficam fora do projeto. Disponível em: http://lfg.jusbrasil.com.br/noticias/97875/camara-aprova-lei-de-adocao-mas-casaishomossexuais-ficam-fora-do-projeto. Acesso em 13 jun. 2015.

Lei $n^{\circ}$ 7.716/1989. Disponível em: http://www.planalto.gov.br/ccivil_03/leis/17716.htm. Acesso em 29 jul. 2013.

PLS 470/2013 - Atividade Legislativa - Projeto e Matérias. Disponível em: www.senado.gov.br/atividade/materia/detalhes.asp?p_cad_mate... Acesso em 26 jul. 2015.

PL 6583/2013 - Câmara dos Deputados. Disponível em: www.camara.gov.br/proposicoesweb/fichadetramitacao?idProposicao... Acesso em 26 jul. 2015 . 
PLS 612/2011 - Atividade Legislativa - Projeto e Matérias. Disponível em: www.senado.gov.br/atividade/materia/detalhes.asp?p_cad_mate... Acesso em 26 jul. 2015.

Projeto de Decreto Legislativo PDC 234/2011. Disponível em http://www.camara.gov.br/proposicoesWeb/fichadetramitacao?idProposicao.... Acesso em 23 jul. 2013.

Projeto de Lei $\mathrm{n}^{\mathrm{o}}$ 1.411/2011. Disponível em: http://www.camara.gov.br/proposicoesWeb/fichadetramitacao?idProposicao=503350 . Acesso em 17 abr. 2015.

PL 580/2007 - Câmara dos Deputados. Disponível em: www.camara.gov.br/proposicoesweb/fichadetramitacao?idProposicao... Acesso em 26 jul. 2015.

PL 2285/2007 - Câmara dos Deputados. Disponível em: www.camara.gov.br/proposicoesweb/fichadetramitacao?idProposicao... Acesso em 26 jul. 2015.

Projeto de Lei $n^{\circ}$ 6.871/2006. Disponível em: http://www.camara.gov.br. Acesso em 17 abr. 2015.

Projeto de Lei $n^{\circ}$ 2.773/2000. Disponível em: http://www.camara.gov.br. Acesso em 17 abr. 2015.

PL 1151/1995 - Câmara dos Deputados. Disponível em: www.camara.gov.br/proposicoesweb/fichadetramitacao?idProposicao... Acesso em 26 jul. 2015.

Anteprojeto do Estatuto da Reprodução Assistida. Disponível em: http://www.oabsp.org.br. Acesso em 07 jun. 2012.

\section{Legislação outros países}

ARGENTINA. Lei de fertilização assistida. Ley $\mathrm{n}^{\mathrm{o}}$ 26.862. Disponível em http://bioetica.flacso.org.ar/textos/ley-26682.pdf. Acesso em 31 mai. 2015.

ARGENTINA. Código Civil Argentino. Disponível em: www.CodigoCivilOnline.com.ar. Acesso em 23 out. 2014.

ARGENTINA. Nuevo Código Civil y Comercial de la Nacion Argentina. Disponível em: http://www.nuevocodigocivil.com/pdf/Texto-del-Projecto-de-Codigo-Civil-y-Comercialde-la-Nacion.pdf Acesso em 23 out. 2014.

FRANÇA. Code Civil. Version Consolidée du Code au 22 décembre 2014. Edition: 201412-28. Disponível em: http://codes.droit.org/cod/civil.pdf. Acesso em 09 jan. 2014. 
FRANÇA. Loi no 2013-404 du 17 mai 2013 ouvrant le mariage aux couples de personnes de même sexe. Disponível em: http://www.legifrance.gouv.fr/affichTexteArticle.do.jsessionid=CD70A5748E4A7484... Acesso em 09 jan. 2014.

PORTUGAL. Lei n $32 / 2006$, que regula as técnicas de Procriação Medicamente Assistida em Portugal (PMA) Revista Portuguesa de Saúde Pública. Disponível em http://www.cdi.ensp.unl.pt. Acesso em 02 jun. 2012.

PORTUGAL. Código Civil Português. Disponível em: http://www.cofap.pt/docs/codcivil.PDF. Acesso em 26 ago. 2013.

URUGUAI. Ley $\mathrm{n}^{\circ}$ 19.075/2013. Matrimonio Igualitário Uruguai. Disponível em: http://www.parlamento.gub.uy/leyes/AcessoTextoLey.asp?Ley=19075\&Anchor Acesso em 16 mai. 2015.

\section{Texto em meio eletrônico}

A adoção feita por homossexuais : batalhas e vitórias legais. Disponível em: http://www.senado.gov.br/noticias/Jornal/emdiscussao/adocao/relatos-reais-sobre-ado... Acesso em 6 jan. 2014.

Adoção e doação: casal homossexual francês adota três irmãos. Disponível em: http://tjrj.jus.br/web/guest/home/-/noticias/visualizar/10011?p_p_state=maximiz... Acesso em 03 abr. 2015.

Adoção Homoparental. Disponível em: http://pt.wikipedia.org/wiki/Ado\%C3\%A7\%C3\%A3o_homoparental. Acesso em 10 jan. 2014.

Apesar de vitória no Supremo, gays ainda vivem em "dois EUA". Disponível em: http://g1.globo.com/mundo/noticia/2013/06/apesar-de-vitoria-no-supremo-gays-ainda... Acesso em 12 jan. 2014.

Câmara aprova projeto que cria o Estatuto das Famílias. Disponível em: http://www.migalhas.com.br/Quentes/17,MI9186,41046-Camara+aprova+projeto+q... Acesso em 03 fev. 2014.

Casamento entre pessoas do mesmo sexo na Argentina. Disponível em: http://pt.wikipedia.org/wiki/Casamento_entre_pessoas_do_mesmo_sexo_na_Argentina Acesso em 28 dez. 2013.

Casamento entre pessoas do mesmo sexo na Espanha. Disponível em: http://pt.wikipedia.org/wiki/Casamento_entre_pessoas_do_mesmo_sexo_na_Espanha. Acesso em 29 dez. 2013. 
Casamento entre pessoas do mesmo sexo na França. Disponível em: http://pt.wikipedia.org/wiki/Casamento_entre_pessoas_do_mesmo_sexo_na_Fran\%C... Acesso em 28 dez. 2013.

Casamento entre pessoas do mesmo sexo no México. Disponível em: http://pt.wikipedia.org/wiki/Casamento_entre_pessoas_do_mesmo_sexo_no_M\%C3... Acesso em 28 dez. 2013.

Casamento entre pessoas do mesmo sexo na Nova Zelândia. Disponível em: http://pt.wikipedia.org/wiki/Casamento_entre_pessaos_do_mesmo_sexo_na_Nova_Z... Acesso em 28 dez. 2013.

Casamento entre pessoas do mesmo sexo no Uruguai. Disponível em: http://pt.wikipedia.org/wiki/Casamento_entre_pessoas_do_mesmo_sexo_no_Uruguai. Acesso em 28 dez. 2013.

Casamento gay é legalizado no Alasca, após recusa do Supremo em suspendê-lo. Disponível em: https://br.noticias.yahoo.com/casamento-gay-\%C3\%A9-legalizado-alascarecusa-supr ... Acesso em 18 mai. 2015.

Casamento gay entra em vigor em Nova York neste domingo. Disponível em: http://veja.abril.com.br/noticia/internacional/a-historia-de-quatro-senadores-conservad... Acesso em 13 jan. 2014.

Casamento homossexual e adoção por casais gays no mundo. Disponível em: http://noticias.terra.com.br/mundo/europa/casamento-homossexual-e-adocao-por-casa Acesso em 07 jan. 2014.

Casamento homossexual e adoção por casais gays no mundo. Disponível em: http://pt.wikipedia.org/wiki/Casamento_entre_pessoas_do_mesmo_sexo_em_Portugal. Acesso em 28 dez. 2014.

Casamento homossexual legalizado no Estado norte-americano do Maine. Disponível em: http://sicnoticias.sapo.pt/mundo/2012/12/29/casamento-homossexual-legalizado-no-es $\quad .$. Acesso em 04 jan. 2014.

Case $N^{\circ}$ S147999 In The Supreme Court of the State of California. Disponível em: http://www.courts.ca.gov/documents/Amer_Psychological_Assn_Amcius_Curiae_Brief. Pdf. Acesso em 01 jun. 2015.

CHADE, Jamil. Entrevista com o Papa Francisco: "Quem sou eu para julgar os gays". Disponível em http://internacional.estadao.com.br/blogs/jamil-chade/entrevista-com-opapa-francisco-quem-so acesso em 29 jun. 2013.

Conselho Nacional de Justiça (CNJ). Dia Internacional contra a Homofobia. Disponível em: http://www.cnj.jus.br/cc6j. Acesso em 17 mai. 2015. 
Decisão da Suprema Corte dos EUA sobre o reconhecimento do casamento homossexual em todo o país. Disponível em: http://edition.cnn.com/2015/06/26/politics/scotus-opiniondocument-obergefell-hodges/index.html. Acesso em 04 jul. 2015.

Delaware se torna $11^{\circ}$ Estado dos EUA a legalizar o casamento gay. Disponível em: http://noticias.terra.com.br/mundo/estados-unidos/delaware-se-torna-11-estado-dos-eu... Acesso em 04 jan. 2014.

Dinamarca aprova lei que permite casamento gay em igrejas. Disponível em: http://noticias.terra.com.br/mundo/dinamarca-aprova-lei-que-permite-casamento-gay Acesso em 07 jan. 2014.

El Tribunal Supremo de Nuevo México legaliza el matrimonio gay. Disponível em: http://sociedad.elpais.com/sociedad/2013/12/19/actualidad/1387483363_160449.html Acesso em 22 dez. 2013.

Entidades pedem ao CNJ regulamentação do casamento civil homossexual. Disponível em: http://www.editoramagister.com/noticia_24320522_ENTIDADES_PEDEM_AO_CNJ_RE GULAMENTACAO_DO_CASAME... Acesso em 17 abr. 2013.

Escócia aprova adoção conjunta para casais homossexuais. Disponível em: http://ibdfam.jusbrasil.com.br/noticias/1932779/escocia-aprova-adocao-conjunta-para...

Acesso em 19 abr. 2015.

Escócia é o $17^{\circ}$ país a aprovar casamento entre homossexuais. Disponível em: http://br.reuters.com/articlePrint?article=BRSPES1308520140204. Acesso em 06 fev. 2014.

Estado de Iowa, nos EUA, autoriza casamento gay. Disponível em: http://www.estadao.com.br/noticias/internacioal.estado-de-iowa-nos-eua-autoriza-casa... Acesso em 04 jan. 2014.

Estado norte-americano de Nevada aprova lei a favor do casamento homossexual. Disponível em: http://www.luminota.com/pt-br/estado-norte-americano-de-nevada-aprovalei-a-favor ... Acesso em 24 mai. 2015.

Estupros Corretivos na África do Sul contra Mulheres Lésbicas. Disponível em: http://www.defesadamulher.com.br/estupros-na-africa-do-sul-contra-mulhe... Acesso em 07 jan. 2014.

EUA: Bispo Católico do Wisconsin diz que o casamento gay ameaça "tudo o que é belo". Disponível em: http://portugalgay.pt/news/180614C/eua_bispo_catolico_do_wisconsin_diz_que_o_ca Acesso em 24 mai. 2015. 
EUA: Com Montana, 35 dos 50 estados já aprovaram o casamento gay. Disponível em: http://revistaladoa.com.br/2014/11/noticias/eua-com-montana-35-dos-50-estados-ja-a $\quad \ldots$ Acesso em 19 mai. 2015.

EUA: Juiz derruba proibição ao Casamento Gay no Colorado. Disponível em: https://nossostons.wordpress.com/2014/07/11eua-juiz-derruba-proibicao-ao-casament...

Acesso em 19 mai. 2015.

EUA: Proibição ao Casamento Gay em Indiana é derrubada. Disponível em: https://nossostons.wordpress.com/2014/06/26/eua-probicao-ao-casamento-gay-em-in Acesso em 24 mai. 2015.

EUA: Tribunal legaliza casamento gay no estado de Utah. Disponível em: http://estadao.com.br/noticia_imp.php?req=internacional,eua-tribunal-legaliza-c... Acesso em 23 jan. 2014.

Flórida se torna o $36^{\circ}$ estado americano a permitir o casamento gay. Disponível em: http://g1.globo.com/mundo/noticia/2015/01/florida-se-torna-o-36-estado-americano-p $\quad .$. Acesso em 18 mai. 2015.

França aprova casamento e adoção para homossexuais. Disponível em: http://www.portugues.rfi.fr/franca/20130423-deputados-franceses-adotam-casamento-...

Acesso em 09 fev. 2014.

Governador de Nova Jersey desiste de apelação contra o casamento gay. Disponível em: http://veja.abril.com.br/noticia/internacional/governador-de-nova-jersey-desiste-de-ap Acesso em 04 jan. 2014.

Governo da França fecha a porta para reprodução assistida para lésbicas. Disponível em: http://noticias.r7.com/internaciona/governo-da-franca-fecha-a-porta-para-reproducao...Acesso em 06 jan. 2014.

Governo dos EUA reconhecerá casamento gay em Utah apesar de bloqueio do Supremo. Disponível em: http://operamundi.uol.com.br/conteudo/noticias/33385/governo+dos+eua+reconher... Acesso em 15 jan. 2014.

Havaí se torna $15^{\circ}$ Estado americano a aprovar casamento gay. Disponível em: http://noticias.terra.com.br/mundo/estados-unidos/havai-se-torna-15-estado-america... Acesso em 03 jan. 2014.

Havaí é o $16^{\circ}$ estado dos EUA a aprovar o casamento gay. Disponível em: http://veja.abril.com.br/noticia/internacional/havai-diz-aloha-ao-casamento-gay. Acesso em 04 jan. 2014.

Hillary GGODRIGE \& OTHERS vs. DEPARTMENT OF PUBLIC HEALTH \& another. SJC-08860. em: 
http://news.findlaw.com/cnm/docs/conlaw/goodrige111803opn.pdf. Acesso em 04 jan. 2014.

Homoparentalidade. Registro Civil. Direito Constitucionalmente Assegurado. Disponível em: http://ibdfam.org.br/jurisprudencia/2336/Homoparentalidade\%0Registro\%20civil\%... Acesso em 14 mar. 2014.

Homossexualidade na Roma Antiga. Antínoo. Disponível em http://pt.wikipedia.org/wiki/Homossexualidade_na_Roma_Antiga; http://pt.wikipedia.org/wiki/Antinoo Acesso em 29 jan. 2014.

Il premier del Lussembrugo ha sposato il suo compagno. Disponível em: http://www.lastampa.it/2015/05/16/esteri/il-premier-del-lussemburgo-ha-sposato-il-su... Acesso em 17 mai. 2015.

Illinois se torna o $16^{\circ}$ estado dos EUA a legalizar o casamento gay. Disponível em: http://g1.globo.com/mundo/noticia/2013/11/illinois-se-torna-o-16o-estado-dos-eua-a-1 Acesso em 03 jan. 2014.

Irlanda aprova casamento gay em votação. Disponível em: http://www1.folha.uol.com.br/fsp/mundo/220339-irlanda-aprova-casamento-gay-emvotacao.shtml. Acesso em 24 mai. 2015.

Justiça aprova adoção por casais gays na Cidade do México. Disponível em: http://oglobo.globo.com/mundo/justica-aprova-adocao-por-casais-gays-na-cidade-do... Acesso em 12 jan. 2014.

Justiça autoriza casamento gay em Idaho, nos EUA, mas governador diz que vai levar "batalha" ao Supremo. Disponível em: http://oglobo.globo.com/sociedade/justificaautoriza-casamento-gay-em-idaho-nos-eua- ... Acesso em 18 mai. 2015.

Justiça condena Levy Fidelix a pagar R \$ 1 milhão por declaração contra gays. Disponível em: http://www.folha.uol.com.br/poder/2015/03/1603549-justica-condena-levy-fidelix-a... Acesso em 17 abr. 2015.

Justiça dá aval a união gay em mais 5 Estados dos EUA. Disponível em: http://www1.folha.uol.com.br/fsp/mundo/189449-justica-da-aval-a-uniao-gay-em-mais-5estados-dos-eua-shtml. Acesso em 18 mai. 2015.

Justiça dá a menino direito de ter três mães. Disponível em http://www.tjdft.jus.br/cidadaos/extrajudicial/extrajudicial-na-midia-justica-da-a-meni...

Acesso em 13 nov. 2014.

Juiz de São Paulo autoriza que dois homens se tornem oficialmente casados. Disponível em: www.aasp.org.br/aasp/imprensa/clipping/cli_noticia.asp?idnot=10137. Acesso em 28 jun. 2011. 
Juiz declara inconstitucional lei de Oklahoma contra casamento gay. Disponível em: http://g1.globo.com/mundo/noticia/2014/01/juiz-declara-inconstitucional-lei-de-oklah... Acesso em 24 mai. 2015.

Juiz dos EUA anula proibição de casamento gay no estado do Oregon. Disponível em: http://noticia.r7.com/internacional/juiz-dos-eua-anula-proibicao-de-casamento-gay0d...

Acesso em 10 de nov. 2014.

Juíza decide a favor do casamento gay em Estado dos EUA. Disponível em: http://www1.folha.uol.com.br/fsp/mundo/152323-juiza-decide-a-favor-do-casamento-gayem-estado-dos-eua.shtm Acesso em 18 mai. 2015.

Juízes americanos derrubam proibição do casamento gay em Nevada e Idaho. Disponível em: http://oglobo.globo.com/sociedade/juizes-americanos-derrubam-proibicao-do-casame ... Acesso em 19 mai. 2015.

La Nouvelle-Zélande légalise le mariage homosexuel. Disponível em: http://www.lemonde.fr/asiepacifique/article/2013/04/17-nouvelle-zelande-legalise. Acesso em 17 abr. 2013.

Lei garante salário maternidade para mulheres e homens adotantes e para casais do mesmo sexo. Disponível em http://www.ibdfam.org.br/noticias/5174/Lei+garante+sal\%C3\%A1rio+maternidade+p...

Acesso em 29 out. 2013.

Luxemburgo aprova casamento e adoção homossexuais. Disponível em: http://www.dn.pt/inicio/globo/interior.aspx?content_id=3981199\&seccao=Europa Acesso em 16 mai. 2015.

Mariage homosexuel. Disponível em: http://fr.wikipedia.org/wiki/Mariage homosexuel. Acesso em 09 jan. 2014.

Mariage homosexuel en Belgique. Disponível em: http://fr.wikipedia.org/wiki/Mariagehomosexuel_en_Belgique. Acesso em 07 jan. 2014.

$\begin{array}{lll}\text { Maternidade } & \text { Socioafetiva. } & \text { Disponível }\end{array}$ http://esaj.jus.br/apo/sg/search.do?ConversationId=\&paginaConsulta=1\&localPesquisa.cd Loca. Acesso em 27 out. 2013.

Maryland, Maine e Washington aprovam casamento gay, dizem TVs. Disponível em: http://g1.globo.com/mundo/eleicoes-nos-eua/2012/noticia/2012/11/maryland-maine-e ...Acesso em 13 jan. 2014.

Menina será registrada por um pai e duas mães homossexuais. Disponível em: httP://www.conjur.com.br/2015-fev-22/menino-registrado-pai-duas-maes-homossexu... Acesso em 12 mai. 2015. 
New Hampshire se torna $6^{\circ}$ Estado dos EUA a legalizar união gay. Disponível em: http://www1.folha.uol.com.br/folha/mundo/ult94u576314.shtml. Acesso em 04 jan. 2014.

Novo México legaliza casamento homossexual nos Estados Unidos. Disponível em: http://g1.globo.com/mundo/noticia/2013/12/novo-mexico-legaliza-casamento-homoss... Acesso em 03 jan. 2014.

O matrimônio homossexual já é legal em toda a costa leste dos EUA. Disponível em: http://brasil.elpais.com.br/brasil/2014/05/21/sociedad/1400694107_459810.html. Acesso em 15 mai. 2015.

Obama conquista votos em Rhode Island com apoio ao casamento gay. Disponível em: http://noticias.terra.com.br/mundo/oriente-medio/obama-conquista-votos-em-rhode-isl...

Acesso em 14 jan. 2014.

Opositores do casamento gay pedem suspensão das uniões na Califórnia. Disponível em: http://g1.globo.com/mundo/noticia/2013/06/opositores-do-casamento-gay-pedemsuspensão-da Acesso em 14 jan. 2013.

Opositores do casamento gay em Massachusetts são derrotados. 27 jan. 2006. Disponível em: http://www1.folha.uol.com.br/folha/mundo/ult94u103192.shtml. Acesso em 04 jan. 2014.

Pais podem registrar filho gerado em barriga de aluguel. Disponível em: http://www.conjur.com.br/2012-ju-17/pais-podem-registrar-filho-gerado-barriga-alugueldecide-tj-mt. Acesso em 18 jul. 2012.

País tem primeira declaração de nascido vivo em nome de duas mães. Disponível em: http://ibdfam.org.br/noticias/5213+Pa\%ADs+tem+primeira+delcara\%C3\%A7\% ... Acesso em 18 dez. 2013.

Parlamento da Islândia aprova casamento gay por unanimidade. Disponível em: http://oglobo.globo.com/mundo/parlamento-da-islandia-aprova-casamento-gay-por-un Acesso em 10 jan. 2014.

Parlamento Norueguês aprova casamento gay e adoção por homossexuais. Disponível em: http://g1.globo.com/Noticias/Mundo/O,MUL604456-5602,00.html. Acesso em 04 jan. 2014.

Perdão a Cientista Homossexual Alan Turing vem com Seis Décadas de Atraso. Disponível em: http://www.dw.de/perd\%C3\%A3o-a-cientista-homossexual-alan-turingvem-com-seis-d\%C3\%A9c... Acesso em 26 dez 2013.

Parlamento português rejeita adoção por casais homossexuais. Disponível em: http://exame.abril.com.br/mundo/noticias/parlamento-portugues-rejeita-adocao-por-ca... Acesso em 21 abr. 2015. 
Portugal torna-se o quinto país a aprovar co-adopção por casais homossexuais. Disponível em: http://www.publico.pt/politica/noticia/parlamento-aprova-coadopcao-homossexual-15 Acesso em 11 jan.2014.

Primeiro casal gay se casa em estado mexicano de Jalisco com amparo judicial. Disponível em: http://noticias.uol.com.br/ultimas-noticias/efe/2013/12/2014/primeiro-casal-gay-secasa-... Acesso em 03 jan. 2014.

Projeto de Estatuto das Famílias é apresentado no Senado. http://ibdfam.org.br/noticias/5182/Projeto+de+Estatuto+das+Fam\%C3\%ADlias+C3 ...

Acesso em 13 nov. 2013.

Rainha Elizabeth II oficializa lei do Casamento Gay. Disponível em: http://veja.abril.com.br/noticia/internacional/rainha-oficializa-a-lei-do-casamento-gay-... Acesso em 04 jan. 2014.

Reichsführer-SS. Disponível em http://pt.wikipedia.org/wiki/Reichsf\%C\%BChrer-SS. Acesso em 05 jan. 2014.

Rhode Island é o $10^{\circ}$ estado a permitir casamento gay. Disponível em: http://www.dn.pt/Common/print.aspx?content_id=3197981 acesso em 14 jan. 2014.

Same-sex marriage in Mexico City. Disponível em: http://en.wikipedia.org/wiki/Samesex_marriage_in_Mexico_City. Acesso em 03 jan. 2013.

Same-sex marriage in the District of Columbia. Disponível em: http://en.wikipedia.org/wiki/Same-sex_marriage_in the_District_of_Columbia. Acesso em 15 jan. 2014.

São Paulo faz primeiro casamento civil direto entre mulheres. Disponível em: http://www.ibdfam.org.br/impressao.php?=clipping\&n=5080. Acesso em 30 ago. 2011.

Suprema Corte aprova casamento gay em cinco estados. Disponível em: http://veja.abril.com.br/noticia/mundo/suprema-corte-aprova-casamento-gay-em-cinc...

Acesso em 09 nov. 2014.

Suprema Corte da Índia mantém sexo entre gays como crime. Disponível em: http://oglobo.com/mundo/suprema-corte-da-india-mantem-sexo-entre-gays-com... Acesso em 11 dez. 2013.

Suprema Corte dos EUA autoriza casamento gay no Alabama. Disponível em: http://g1.globo.com/mundo/noticia/2015/02/suprema-corte-dos-eua-autoriza-casament $\quad \ldots$ Acesso em 18 mai. 2015.

Supremo dos EUA bloqueia temporariamente casamento gay em Utah. Disponível em: http://noticias.bol.uol.com.br/ultimas-noticias/brasil/2014/01/06/supremo-dos-eua-blo... Acesso em 07 jan. 2014. 
Supremo rejeita denúncia contra Feliciano por crime de homofobia. Disponível em http://www.conjur.com.br/2014-ago-12/stf-rejeita-denuncia-feliciano-homofobia... Acesso em 13 ago. 2014.

Supremo suspende casamento gay em dois Estados dos EUA. Disponível em: http://noticias.terra.com.br/mundo/estados-unidos/supremo-suspende-casamento-gay-...

Acesso em 19 mai. 2015.

STJ reconhece a dissolução de união homoafetiva cumulada com partilha de bens. Disponível em: http://www.migalhas.com.br/Quentes/17,MI133719,91041-

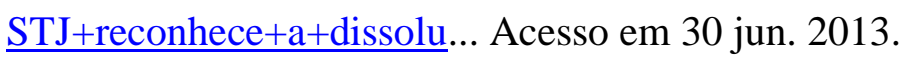

Templo feito por imperador romano a seu amante é achado na Itália. Disponível em http://www1.folha.uol.com.br/folha/ciencia/ult306u7649.stml. Acesso em 29 jan. 2014.

Tribunais de 12 estados e do DF autorizam casamento civil de pessoas do mesmo sexo. Disponível em: http://oglobo.globo.com/pais/tribunais-de-12-estados-e-odf-ja-autorizamcasamento-c... Acesso em 10 mai. 2013.

TJ-RS reconhece possibilidade de casamento homoafetivo. Disponível em: http://www.conjur.com.br/2012-set-27/tj-rs-anula-decisao-nao-reconheceu-casamento...

Acesso em 08 out. 2012.

Uganda aprova lei rigorosa para reprimir homossexualidade. Disponível em: http://g1.globo.com/mundo/noticia/2013/12/uganda-aprova-lei-rigorosa-para-reprimir...

Acesso em 21 dez. 2013.

Uganda. Legislação Discriminatória Alimentam Abusos e Repressão. Disponível em: http://anistia.org.br/noticias/uganda-legislacao-discriminatoria-alimentam-abusos-erepressao/ Acesso em 22 out. 2014.

Uruguai aprova união civil entre gays. Disponível em: http://g1.globo.com/Noticias/Mundo/0..MUL232721-5602.00-

URUGUAI+APROVA+UNIA Acesso em 11 jan. 2014.

Vermont ultrapassa veto e legaliza casamento "gay". Disponível em: http://www.publico.pt/sociedade/noticia/vermont-ultrapassa-veto-e-legaliza-casamento. Acesso em 04 jan. 2014.

Washington legaliza casamento entre pessoas do mesmo sexo. Disponível em: http://operamundi.uol.com.br/conteudo/noticias/19854/washington+legaliza+casamento... Acesso em 13 jan. 2014.

Virgínia é $20^{\circ}$ estado americano a legalizar casamento gay. Disponível em: http://arpensp.jusbrasil.com.br/noticias/130005677/virginia-e-20o-estado-americano-... Acesso em 18 mai. 2015. 